University of South Carolina

Scholar Commons

$1-2010$

\title{
A History of American Settlement at Camp Atterbury
}

Steven D. Smith

University of South Carolina - Columbia, smiths@mailbox.sc.edu

Chris J. Cochran

Engineer Research and Development Center Champaign IL Construction Engineering Research Lab

Follow this and additional works at: https://scholarcommons.sc.edu/anth_facpub

Part of the Anthropology Commons

\section{Publication Info}

Published in 2010.

(C) 2010, U.S. Army Corps of Engineers, Construction Engineering Research Laboratories.

This Book is brought to you by the Anthropology, Department of at Scholar Commons. It has been accepted for inclusion in Faculty Publications by an authorized administrator of Scholar Commons. For more information, please contact digres@mailbox.sc.edu. 
The History of American

\section{Settlement at Camp Atterbury}

\section{US Army Corps of Engineers $s_{\circledast}$}

Engineer Research and Development Center

Steven D. Smith and Chris J. Cochran

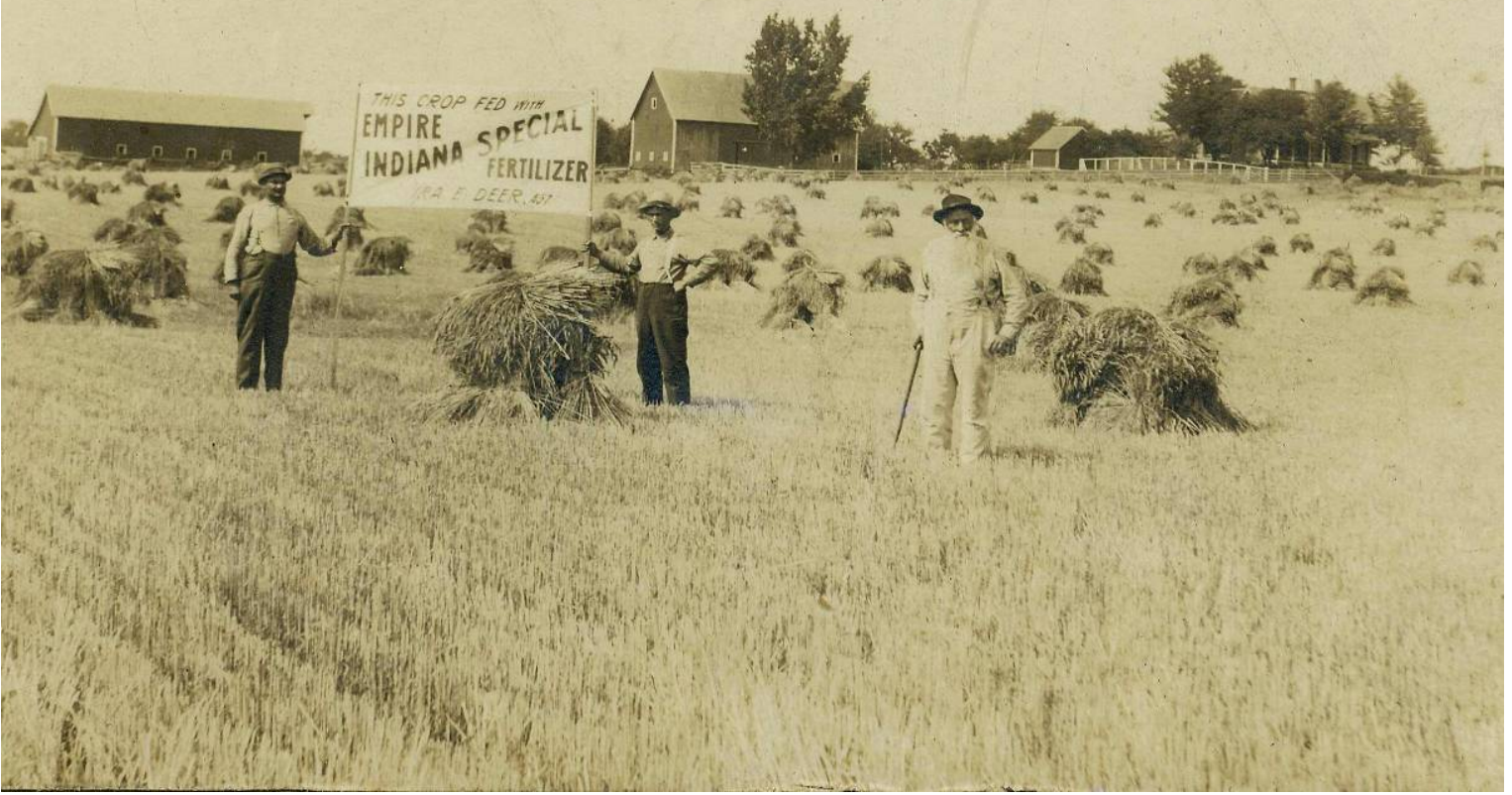




\title{
The History of American Settlement at Camp Atterbury
}

\author{
Steven D. Smith \\ South Carolina Institute of Archaeology and Anthropology \\ 1321 Pendleton Street \\ Columbia, SC 29208 \\ Chris J. Cochran \\ Construction Engineering Research Laboratory \\ U.S. Army Engineer Research and Development Center \\ 2902 Newmark Drive \\ Champaign, IL 61822
}

Final Report

Approved for public release; distribution is unlimited.

\footnotetext{
Prepared for Camp Atterbury Joint Maneuver Training Center Environmental Office PO Box 5000

Edinburgh, IN 46124
} 


\begin{abstract}
This report details the history of $19^{\text {th }}$ and $20^{\text {th }}$ century farm and community settlement within the Camp Atterbury J oint Maneuver Training Center, IN. It also provides a historic context for the identification, evaluation, and preservation of significant historic properties within installation boundaries. This historic context defines property types, poses research questions, and provides evaluation criteria based on the Camp Atterbury J oint Maneuver Training Center's settlement history, in an effort to develop a comprehensive program of multiple site evaluation.
\end{abstract}

DISCLAIMER: The contents of this report arenot to beused for advertising, publication, or promotional purposes. Citation of trade names does not constitute an official endorsement or approval of the use of such commercial products. All product names and trademarks cited are the property of their respective owners. The findings of this report are not to be construed as an official Department of the Army position unless so designated by other authorized documents. 


\section{Table of Contents}

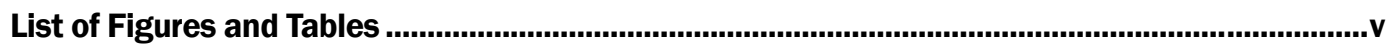

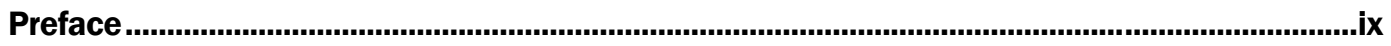

Unit Conversion Factors..........................................................................................................................

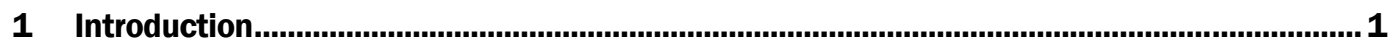

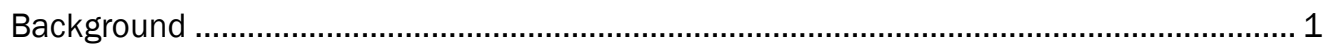

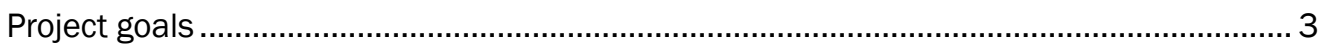

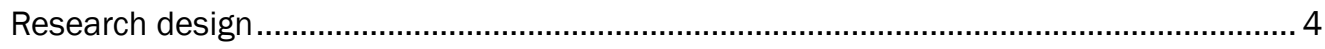

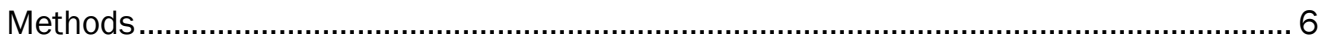

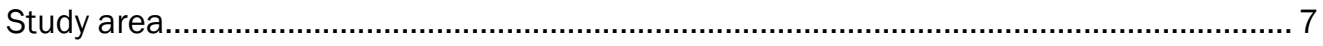

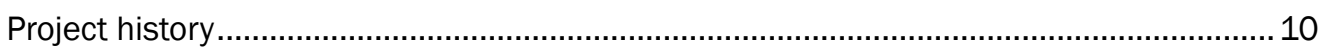

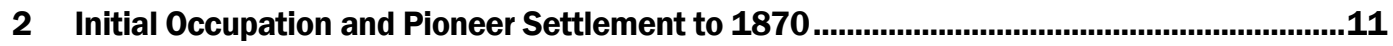

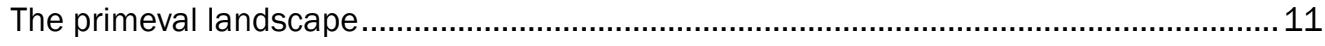

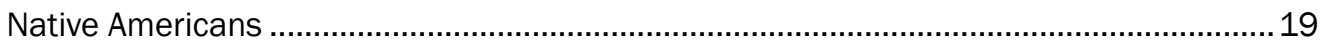

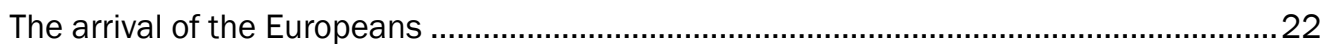

Initial settlement of Camp Atterbury ..........................................................................2

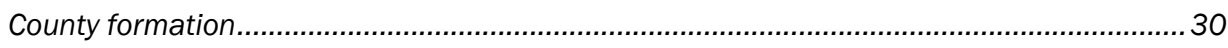

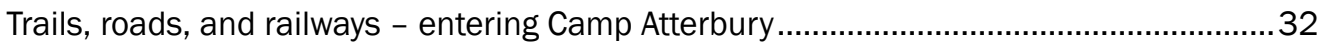

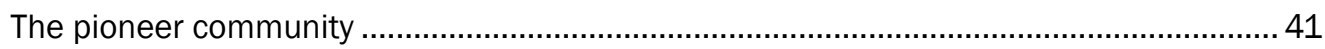

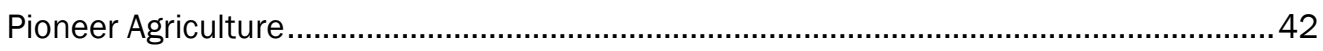

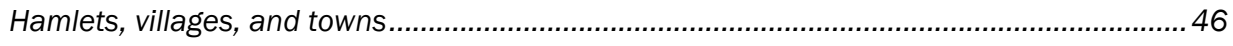

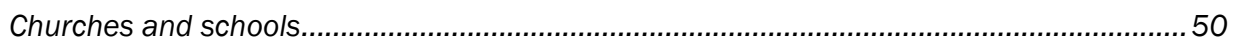

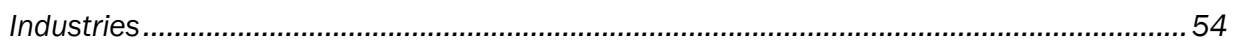

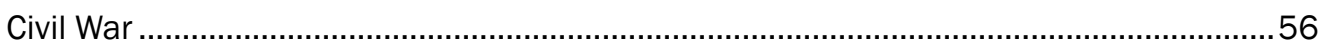

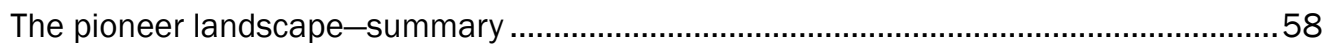

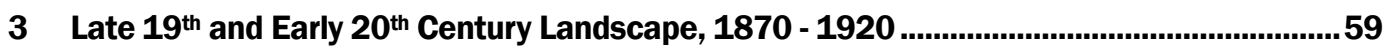

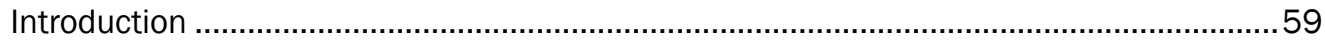

Late $19^{\text {th }}$ century social organization.......................................................................... 70

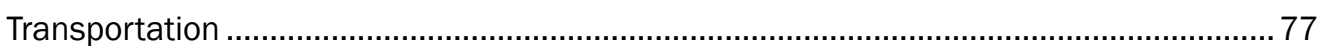

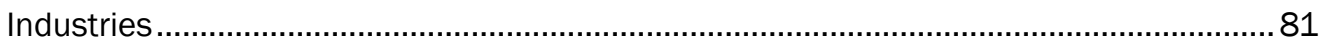

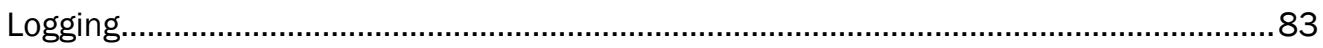

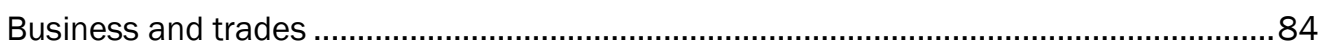

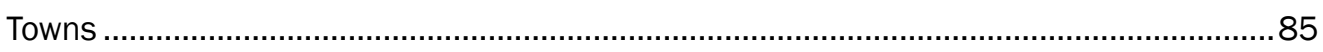

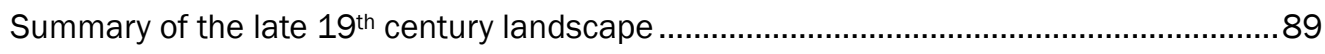

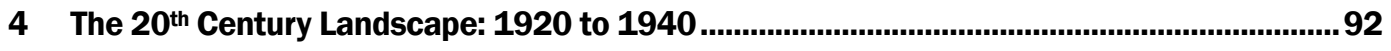

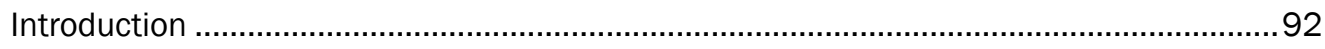

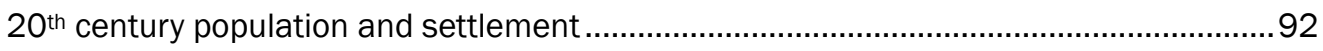

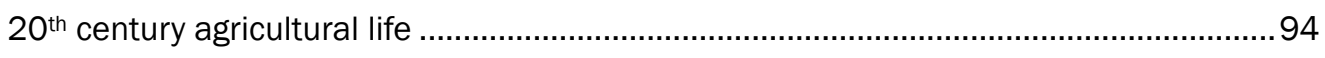




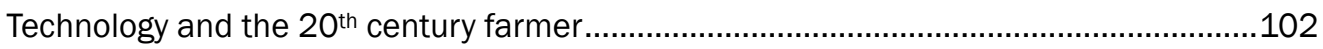

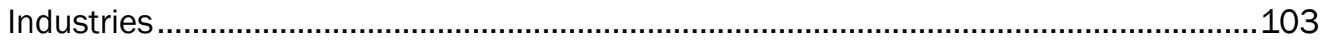

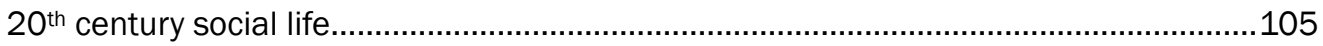

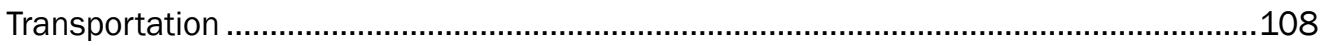

Towns

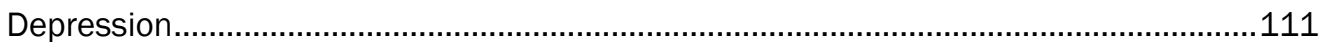

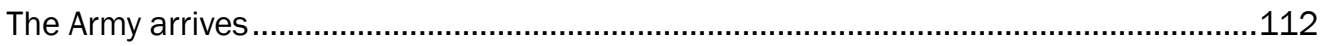

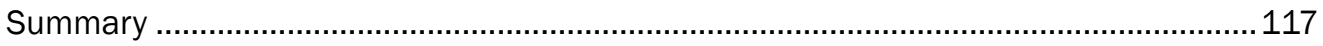

5 Landscape, Context, and Management for Historic Period Sites at Camp Atterbury....... 119

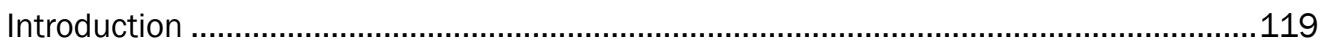

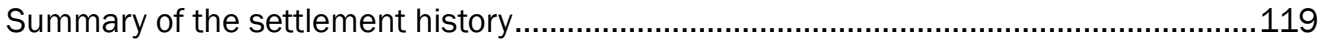

Historic context: becoming Hoosiers at the margin of corn belt culture ..........................124

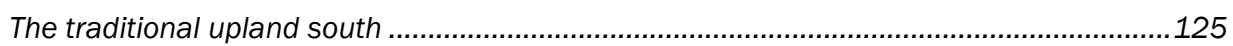

Mid-Atlantic and New England tradition ....................................................................127

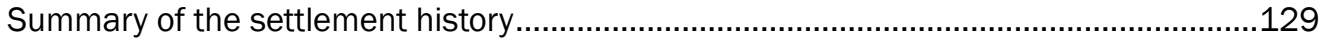

Agricultural continuum: From upland South to corn belt agriculture ...............................135

Archaeological manifestations of the upland South to corn belt culture..........................140

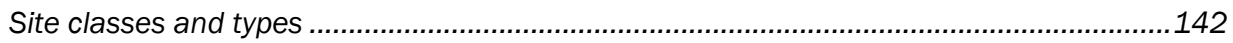

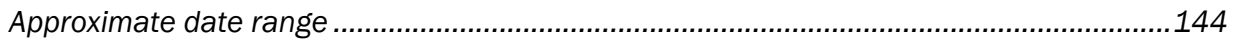

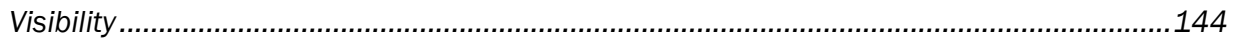

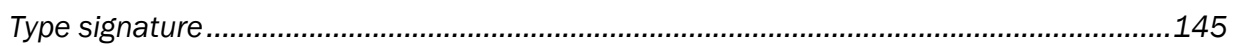

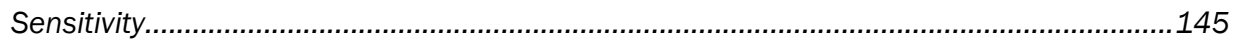

Research questions for eligibility determinations ......................................................146

Theme: Becoming hoosiers, at the margin of corn belt culture .........................................146

Theme: Pioneer history …………………………………..........................................148

Theme: Corn belt history .............................................................................................. 148

Theme: Midwestern industry, business and agricultural specialization ..............................149

Theme: The depression landscape ..............................................................................149

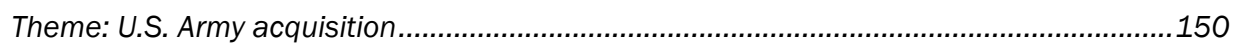

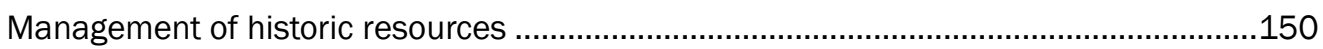

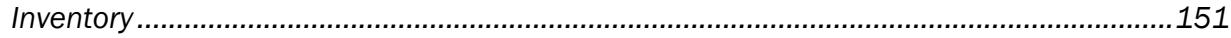

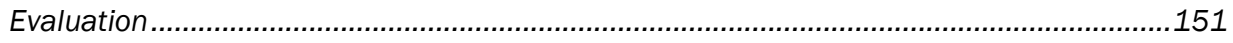

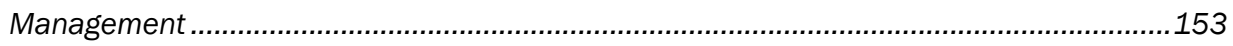

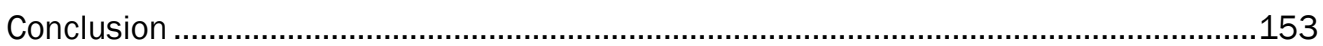

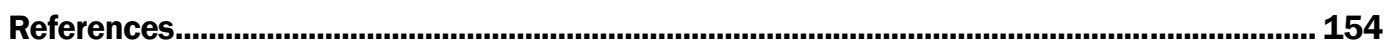

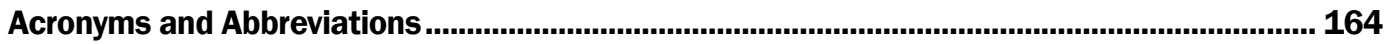

Report Documentation Page .......................................................................................................... 165 


\section{List of Figures and Tables}

\section{Figures}

1 Location of Camp Atterbury Joint Maneuver Training Center (in red) ................................... 2

2 Camp Atterbury Joint Maneuver Training Center (courtesy Camp Atterbury)........................ 2

3 Camp Atterbury Joint Maneuver Training Center Township, Range, and Section map

4 Close-up of Indiana glacial map. Green indicates Wisconsinan Glacial Maximum and Tipton Plain. White indicates limit of older drifts, purple till soils, orange sand and gravel glacial outwash. Red block location of Camp Atterbury (Indiana Geological Survey Map 26)...

5 Principal creeks and rivers draining Camp Atterbury (courtesy Camp Atterbury)

6 Historic Indian Tribes at the time of initial settlement, ca. 1800. Approximate location of the Camp Atterbury in red (Courtesy Jackson 1997:368, modified from map by Daniel Hough)

7 Succession of Indian treaties incorporating modern Indiana. Approximate location of Camp Atterbury in red.

8 Portion of a map of land purchases, Blue River Township, Johnson County, IN, 1820-1850 (courtesy Atlas of Johnson County)

9 Portion of a map of land purchases 1820 to 1850 in Nineveh Township, Johnson County (courtesy Atlas of Johnson County)

10 Roads and towns 1845 depicting also earliest trails to Camp Atterbury region. Approximate location of Camp Atterbury in Red (map modified from Hoover and Rodman 1980:69 original by Clark Ray)

11 Portion of Young and Dinn Pioneer map of Johnson County, depicting Berry Trail, Mauxferry Road, early settlers and mills in the area. Collier's Mill is within Camp Atterbury (courtesy Young and Dinn n.d.)

12 Portion of Young and Dinn Pioneer Map of Johnson County depicting Berry Trail, Mauxferry trail, early settlers and Williamsburg in Nineveh Township (courtesy Young and Dinn n.d.)

13 Enlargement of a portion of Colton's 1852 map of Indiana (courtesy Library of Congress Collection of Indiana Historical Maps on-line).

14 Portion of Johnson's 1858 Railroad map of Indiana. Compare to Fig Road from Columbus to Taggart's and Martinsville complete. Also road from Edinburgh to Williamsburg in place. Red outlines the Camp Atterbury region. (Courtesy Library of Congress collection of Indiana Historical Maps on-line).

15 Plat of hamlet of Kansas, in Bartholomew County, IN, within the CAJMTC. (courtesy Atlas of Bartholomew County, 1879.)

161866 plat of Williamsburg, Nineveh P.O. (courtesy, Atlas of Johnson County, IN, 1984)

17 Churches, schools, and mills east of Edinburgh in the mid-19th century (courtesy Atlas of Johnson County, 1984).

18 Churches and schools in the Williamsburg community in the mid-19th century (courtesy Atlas of Johnson County, 1984 
19 Landowners circa 1879, Union Township, Bartholomew County (courtesy Beers 1879:37)

20 Landownership, circa 1879, Nineveh Township, Bartholomew County (courtesy Beers 1879:37).

21 Enlargement of Landowner map, Nineveh Township, Johnson County, circa 1881 (courtesy Atlas of Johnson County).

22 Enlargement of a portion of Blue River Township, Johnson County, circa 1881 at confluence of Sugar Creek and Blue River. (courtesy Atlas of Johnson County)

23 Thomas Blackwell farm in 1916, farm laborers holding banner championing Empire Fertilizer. (Courtesy Johnson County Historical Society, Franklin, IN)

24 Churches, Schools, and road network, Nineveh and Union Townships,

Bartholomew County, circa 1888 (courtesy BaCHS 1976:front inset)

25 Churches, Schools, road network, Nineveh and Blue River Townships, Johnson County, circa 1881 (courtesy Atlas of Johnson County)

26 Churches, schools, and roads, Hamblen Township, Brown County, circa 1876

27 Nineveh High School, circa 1885 (courtesy Johnson County Historical Society, Franklin, IN)

28 Complaint for non payment of Toll, Bartholomew County (courtesy Bartholomew County Historical Society, Columbus, IN).

29 Enlargement of 1906 Mendelhall's Guide and Road Map of Indiana (courtesy IUPUI Digital Library Collection, on-line).

30 Furnas Mill at Sugar Creek, Blue River Township, Johnson County (courtesy Johnson County Historical Society, Franklin, IN)

31 Enlargement of Galbraith's Railway Mail Service Map of 1897 (courtesy Library of Congress American Memory Collection, on-line) .86

32 Williamsburg -Nineveh, 1900 (courtesy Atlas of Johnson County)

33 The Drybread farm in late 19th century, an example of a prosperous farmer of the Tipton Plain in Johnson County and within Camp Atterbury (courtesy Atlas of Johnson County).

34 The Joshua Richardson cabin. Although located near Hensley (Trafalgar) in Johnson County, it is thought to be representative of the home steads in the hills section of Camp Atterbury (courtesy Johnson County historical Society)

35 Nineveh Township, Bartholomew County Plat Map, circa 1925 to 1941 (courtesy IUPUI Digital Map Collections on-line).

36 Union Township, Bartholomew County Plat Map, circa 1925 to 1941 (courtesy IUPUI Digital Map Collections on-line)

37 Blue River Township, Johnson County Plat Map, circa 1925 to 1941 (courtesy IUPUI Digital Map Collections on-line).

38 Nineveh Township, Johnson County Plat Map, circa 1925 to 1941 (courtesy IUPUI Digital Map Collections on-line).

39 Hamblen Township, Brown County Plat Map, circa 1925 to 1941 (courtesy IUPUI Digital Map Collections on-line)

40 Although from an 19th century atlas, this farm scene is typical of a diversified "stock" farm on the edge of the Tipton Plain in Johnson County in the early 20th century (from Atlas of Johnson County). 
41 Canning Factory in Trafalgar, Johnson County Indiana, just north of Brown County (Courtesy Johnson County Historical Society Museum).

42 Schaefer and Schwartzkopf Mill and elevator in Columbus, IN. Camp Atterbury farmers turned to large mills in the 20th century once roads were improved (from Marshall and Prather 2003:103)..............................................................................104

43 Kansas Methodist Church, circa 1940s (courtesy Camp Atterbury Museum) ..................105

44 Ohio Ridge Church, circa 1940s (courtesy Camp Atterbury Museum).............................105

45 Precinct School, circa 1930s (courtesy Herman Johnson)................................................ 107

46 Kids in front of Records School, circa 1920s (courtesy Herman Johnson)....................... 107

47 This enlargement of a 1912 touring map indicates the better roads in the Camp Atterbury region during the first half of the $20^{\text {th }}$ century (from Scarborough's Road Map and Motor Guide of Indiana, 1912) .............................................................109

48 Dinn Store at Kansas shortly before Army Acquisition (courtesy Camp Atterbury Museum)

49 George and Alice Stillabower home circa 1942 (courtesy Camp Atterbury Museum).

50 Emily Long stands in front of her home after Camp Atterbury acquisition. Sign on door reads "No Trespassing, U.S. Government Property" (courtesy Camp Atterbury Museum).

51 An example of a home in Brown County, during the Depression, depicting the contrast between Camp Atterbury residents and those in extreme poverty. These people were resettled (courtesy Reid 1987:3)..............................................................118

52 Area of farmstead (in percent)...............................................................................

53 Relationship of farmstead to a public highway (in percent)............................................132

54 Number of separate buildings on farmstead (in percent)...............................................133

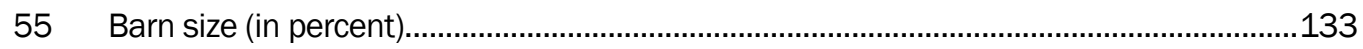

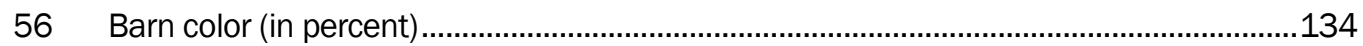

$57 \quad$ Number of rooms in farmhouse (in percent)..............................................................134

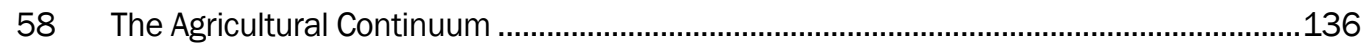

59 Generalized regions for Camp Atterbury Agriculturalists ................................................138

\section{Tables}

1 Population of Bartholomew, Johnson, and Brown Counties, 1830-1850 41

2 Population of Nineveh and Union Townships, Bartholomew County, Nineveh and Blue River, Johnson County, and Hamblen Township, Brown County, 1860 and 1870. Parentheses indicates Black population.

3 Farm sizes for Bartholomew, Brown and Johnson Counties, IN in 1860 ............................44

4 Selected livestock production for tri-county region 1840 through 1870 ............................45

5 Selected crop production for tri-county area in 1840. Wheat, rye-oats, corn, potatoes in bushels, wool and tobacco in pounds, hay in tons.

6 Selected crop production for tri-county area in 1850. Wheat, rye-oats, corn, potatoes in bushels, wool, tobacco, butter-cheese in pounds, hay in tons.

7 Selected crop production for tri-county area in 1860. Wheat, rye-oats, corn, potatoes in bushels, wool, tobacco, butter-cheese in pounds, hay in tons 
8 Selected crop production for tri-county area in 1870. Wheat, rye-oats, corn, potatoes in bushels, wool, tobacco, butter-cheese in pounds, hay in tons.

9 Population of townships incorporating Camp Atterbury from 1870 to 1920. Numbers in parentheses indicates Black population.

10 Selected crop production in the tri-county region of Camp Atterbury, 1880 to 1920 66

11 Selected livestock production in the tri-county region of Camp Atterbury, 1880 to 1920 66

12 Farm size for owner-operated farms in the tri-county Camp Atterbury region, 1890

13 Farm size for fixed rent farms in the tri-county Camp Atterbury region, 1890 ...................67 67

14 Farm size for share rented farms in the tri-county Camp Atterbury region, 1890..............67

15 Owner operator farm size in Bartholomew County, 1900 through 1920 ...........................68

16 Owner operator farm size in Brown County, 1900 through 1920......................................68

17 Owner operator farm size in Johnson County, 1900 through 1920 ....................................68

18 Population for Camp Atterbury Townships, 1920 through 1940. Black population

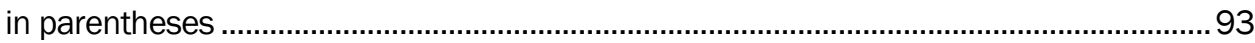

19 Crop production for Camp Atterbury Townships, 1920 to 1940. Wheat, rye and oats, and corn in bushels, wool, tobacco, and butter/cheese in pounds, and hay in tons 98

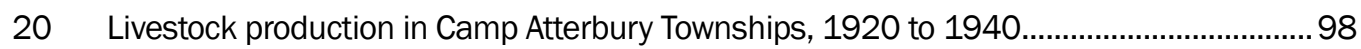

21 Farm sizes and percent ownership for Bartholomew County, 1920 to 1940 .....................99

22 Farm sizes and percent ownership for Brown County, 1920 to 1940...............................99

23 Farm sizes and percent ownership for Johnson County, 1920 to 1940 ……....................99

24 Classes and types of archaeological sites in Camp Atterbury, IN.....................................142 


\section{Preface}

This study was conducted for the Camp Atterbury J oint Maneuver Training Center (CAJ MTC), IN, under Project No. 155652, "19th/20th Century Historic Context." Funding was provided by Military Interdepartmental Purchase Request (MIPR) 21/ 2020/220/ MIPR89DATIN060, dated 14 July 2008. The CAJ MTC technical monitor was Ms. Karstin (Kari) Carmany-George, Cultural Resource Manager.

The work was performed by the Land and Heritage Conservation Branch (CN-C) of the Installations Division (CN), Construction Engineering Research Laboratory (CERL). Adam Smith was the CERL Project Manager. The report was a collabo-rative effort through the Cooperative Ecosystems Studies Unit (CESU) between CERL and the South Carolina Institute of Archaeology and Anthropology (SCIAA) part of the University of South Carolina. Steven D. Smith was the pri-mary author from SCIAA and Chris $\mathrm{J}$. Cochran with help from Sunny Adams was the primary author from CERL. Special acknowledgement is given to those who assisted with the formation of this report: Kari Carmany-George and Kirsten M. Lewis, CAJ MTC; the archivists and librarians at the J ohnson County, Bartholomew County, and Brown County historical societies; Sarah Rogers, Director, Brenna Cundiff, Curator, and Linda Talley Librarian at the J ohnson County Mu-seum of History; Mary Ann McCray at the Bartholomew County Historical Soci-ety; former Camp Atterbury residents Herman J ohnson, Shirley Neville Brown, and David Staughn; and finally additional assistance came from J ames D. West, website master of www.indianamilitary.org and Dr. Frank R. Scheer, curator, Railway Mail Service Library, in Boyce, Virginia. Dr. Christopher White is Chief, CN-C, and Dr. J ohn Bandy is Chief, CN. The Deputy Director of CERL is Dr. Kirankumar V. Topudurti. The Director of CERL is Dr. Ilker R. Adiguzel.

CERL is an element of the U.S. Army Engineer Research and Development Center (ERDC), U.S. Army Corps of Engineers. The Commander and Executive Director of ERDC is COL Gary E. J ohnston, and the Director of ERDC is Dr. James R. Houston. 


\section{Unit Conversion Factors}

\begin{tabular}{|l|c|l|}
\hline Multiply & By & To Obtain \\
\hline acres & $4,046.873$ & square meters \\
\hline degrees Fahrenheit & $(\mathrm{F}-32) / 1.8$ & degrees Celsius \\
\hline feet & 0.3048 & meters \\
\hline gallons (U.S. liquid) & $3.785412 \mathrm{E}-03$ & cubic meters \\
\hline horsepower (550 foot-pounds force per second) & 745.6999 & watts \\
\hline inches & 0.0254 & meters \\
\hline miles (U.S. statute) & $1,609.347$ & meters \\
\hline square feet & 0.09290304 & square meters \\
\hline square miles & $2.589998 \mathrm{E}+06$ & square meters \\
\hline square yards & 0.8361274 & square meters \\
\hline yards & 0.9144 & meters \\
\hline
\end{tabular}




\section{Introduction}

\section{Background}

On 6 J anuary 1942, the U.S. Army announced that it would build a 40,000 plus acre training camp in rural central Indiana (now 33, 132 acres), composed of parts of southeastern J ohnson, northwestern Bartholomew, and a slice of northeastern Brown County, IN (Figures 1 and 2) (West 2005). By April of that year, over 15,000 workers had been employed to construct the camp, and on 15 August 1942, the Eighty-Third Infantry Division was activated at Camp Atterbury, IN. During the previous summer and fall, articles about the Army's planned invasion filled local Franklin and Columbus, IN newspapers providing the families in the area advanced warning. However, less than 6 months after the official announcement, hundreds of Indiana landowners, mostly farmers, had been displaced from their land to make way for the camp's construction. Their ancestral home since the early 1820s was now Camp Atterbury. This settlement history is their story.

This settlement history of the Camp Atterbury region, now the Camp Atterbury J oint Maneuver Training Center (CAJ MTC) under the command of the Indiana National Guard, was prepared through Cooperative Agreement W9132T-09-2-0004, between Engineer Research and Development Center-Construction Engineering Research Laboratory (ERDC-CERL, Champaign, IL) and the University of South Carolina Research Foundation, Columbia, SC, via the Piedmont South Atlantic Coast Cooperative Ecosystems Studies Unit. The project was awarded 28 December 2008. The work was performed as a cooperative effort between the South Carolina Institute of Archaeology and Anthropology, University of South Carolina, and the ERDC-CERL on behalf of and funded by the Indiana Army National Guard and the National Guard Bureau as part of their comprehensive cultural resources management program. 

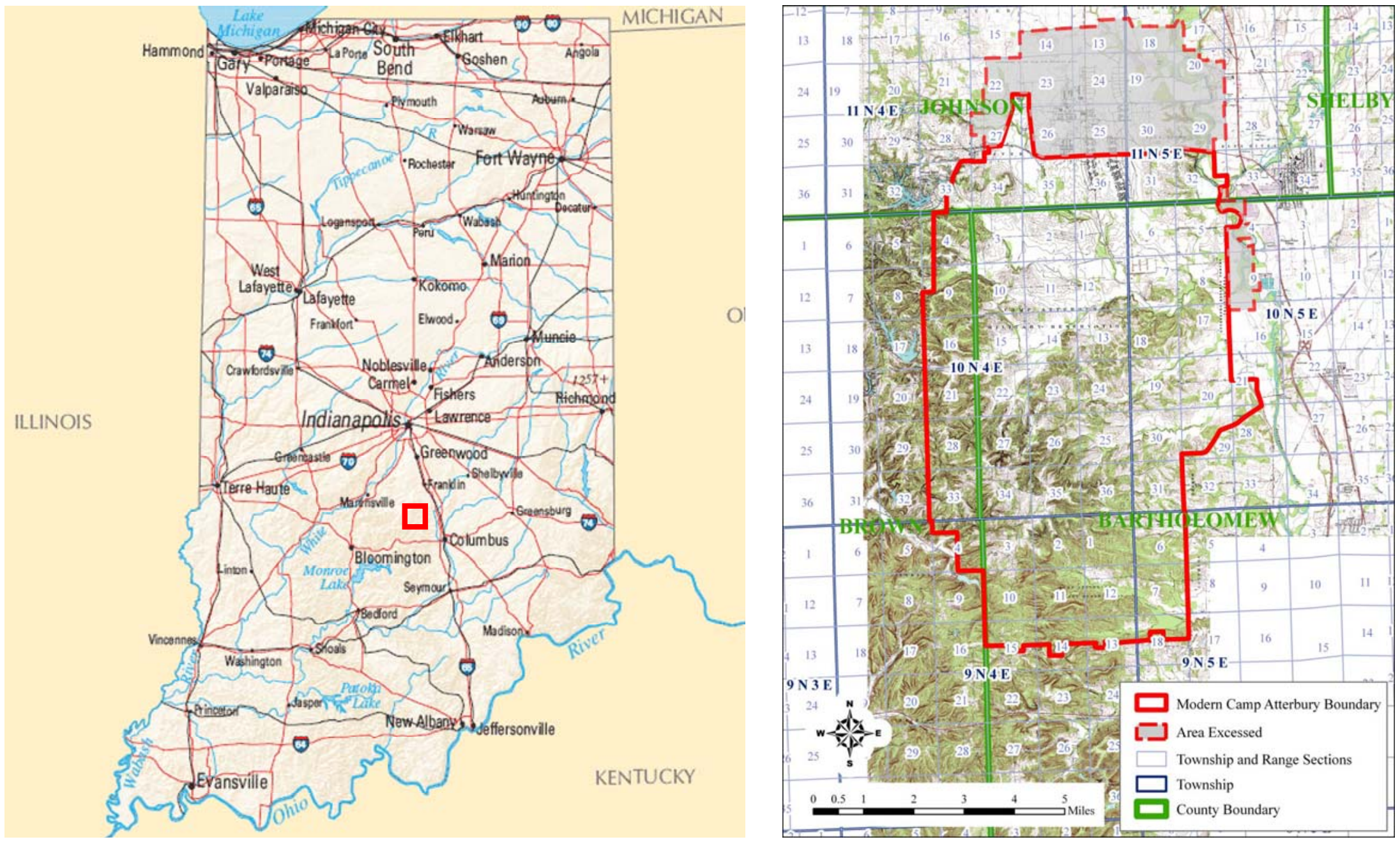

Figure 1. Location of Camp Atterbury Joint Maneuver Training Center (in red).

Figure 2. Camp Atterbury Joint Maneuver Training Center (courtesy Camp Atterbury). 


\section{Project goals}

The archaeological remains of Camp Atterbury's historic settlers are collectively known as cultural resources. Cultural resources have special significance to America's past and when listed on or are eligible for listing on the National Register of Historic Places (NRHP) are known as historic properties. In 1966, the National Historic Preservation Act (P.L. 89-665, 16 U.S.C. 470 et seq., as amended 2006) recognized that “ ...the preservation of this irreplaceable heritage [i.e., historic properties significant to the Nation's heritage] is in the public interest so that its vital legacy of cultural, educational, aesthetic, inspirational, economic, and energy benefits will be maintained and enriched for future generations of Americans" (NHPA Section 1(b)(4)). This act, and subsequent related legislation, required Federal agencies, like the U.S. Army and the National Guard Bureau, to inventory, preserve, and manage historic properties. Furthermore, Department of Defense Instructions 4715.3 and AR 200-1 provide Army policy, procedures, and responsibilities for the management of historic properties on Army installations. Historic properties are technically defined as "any prehistoric or historic district, site, building, structure, or object included in, or eligible for inclusion in, the National Register of Historic Places ..." (36 CFR 800.16 (l)(1)).

The process of inventory, preservation, and managing historic properties involves systematic survey to find and identify sites and buildings (inventory), evaluating their importance to our national history (evaluating), and management of the resources to reduce or eliminate impacts to them. One of the more useful methods of evaluating the significance of cultural resources in order to identify historic properties is the development of historic contexts. Historic contexts are defined as "an organizational format that groups historic properties that share similarities of time, theme and geography" (Advisory Council on Historic Preservation and the National Park Service 1989:7). Historic contexts assist in the definition of property types, pose research questions, and provide evaluation criteria within a historic background allowing a comprehensive program of multiple site evaluation. The goal of this cooperative effort was to develop a historic context for the $19^{\text {th }}$ and $20^{\text {th }}$ century farm and community settlement of what is today the Camp Atterbury J oint Maneuver Training Center (hereafter referred to as Camp Atterbury).

The development of this historic context for $19^{\text {th }}$ and $20^{\text {th }}$ century farm and community settlement at Camp Atterbury should assist cultural resource managers to employ a more encompassing approach to historic archaeo- 
logical site eligibility and management. "This approach should prove to ensure that not only are unique sites recognized, properly evaluated and protected, but also that the best examples of more common sites are also protected. By evaluating the sites in relation to each other, [Camp Atterbury] hopes to reduce the number of sites that require protection and monitoring while at the same time ensuring the sites that are being protected and monitored are not only the unique sites but including the best examples of the more common types of sites" (CERL: Request for Statement of Interest: 7 October 2008).

As a secondary goal, this settlement history is to guide future archaeological efforts for historic sites by providing a series of hypotheses testable during archaeological survey, site testing, and potential data recovery situations. Indeed, archaeological sites are usually determined significant because "...they have yielded, or may likely yield information important to prehistory or history" (36 CFR60.4d). Thus, this settlement history is the first step in providing criteria for the evaluation of particular historic properties and in general providing a better understanding of rural life in south central Indiana.

\section{Research design}

The research purpose of this settlement history is to provide archaeologists with a framework for the evaluation of historic properties (overwhelmingly farmsteads) at Camp Atterbury. As such, the research design for this particular project is in essence to design a research design. In other words, the objective is to discover an overarching theme or themes that define or capture the dominant cultural system(s) at work between the 1820s and 1942, and then use this framework to guide future archaeological efforts. This will be completed through an examination of the developmental history of Camp Atterbury before it was an Army installation.

Since the historic context is aimed at historic archaeological resources, the research framework must have a spatial as well as chronological construct. Previous settlement histories completed for military installations have found that a landscape approach is useful (Smith 1999; 2003). This approach takes a multiscalar perspective, integrating social variables and land-human relationships. The landscape concept has been greatly expanded upon, critiqued, and modified since its introduction by cultural geographer Carl Sauer in the 1920s (David and Thomas 2008; Sauer 1963). However, this project returns to Sauer's more traditional use. Sauer saw landscape as the result primarily of human activity, in which human 
works are inscribed on the earth's surface giving the land its characteristic expression (Sauer 1931:21-24). He also recognized the importance of the historical dynamics of the landscape, the changes or evolution that occurred to create the cultural landscape. Although Sauer was interested in the formation of landscape and the culture that produced it, he was less interested in understanding the culture itself. His focus was on the affect culture had on the landscape. "The cultural landscape is fashioned from a natural landscape by a cultural group. Culture is the agent, the natural area is the medium, the cultural landscape is the result" (Sauer 1963:343). For Carl Sauer the landscape was primarily a place and the artifacts of that place-buildings, roads, and fences.

Likewise, this project takes a more traditional archaeological use of landscape, once termed the "settlement pattern approach" (Chang 1972). According to Carole Crumley and William Marquardt, "The landscape is the spatial manifestation of the relations between humans and their environment" (Crumley and Marquardt 1987:1). Landscape archaeology is a useful method of integrating cultural history (Willey and Phillips 1958; Flannery 1974), cultural geography (Kniffen 1960), spatial analysis (Clarke 1997; Hodder and Orton 1976), and settlement pattern (Chang 1972) research under a single theoretical framework. Landscapes are formed over time as human interactions modify the natural landscape and at the same time the characteristics of the landscape influence human interactions and settlement. The landscape approach is especially useful in cultural resource management, in that it fits well within the framework of historic contexts. Rural landscapes are defined as "a geographical area that historically has been used by people or shaped or modified by human activity, occupancy, or intervention, and that possessed a significant concentration, linkage, or continuity of areas of land use, vegetation, buildings and structures, roads and waterways, and natural features" (McClelland et al. 1991:1-2).

The above definition and use of landscape guides this Camp Atterbury settlement history. Over the course of the following chapters, the author describes or "paints" a series of landscapes beginning with the period just prior to county formation. Four landscapes are described consisting of: (1) the initial primeval landscape of the Native Americans, (2) Pioneer Landscape 1820 to 1877; (3) Late 19th and Early 20th Century Landscape 1877-1920; and (4) the 20th Century Landscape, 1920-1941. The primeval landscape describes the land just prior to the arrival of the first settlers. Within the following landscapes, the development of the settlement system, transportation system, and sociological systems is presented, with a 
goal toward identifying themes and site types. These themes and types are used in the final chapter to identify research topics and evaluation criteria for historic sites at Camp Atterbury. Finally, management policies and practices are recommended, tailored to the site types identified.

\section{Methods}

The primary research method for this project was the gathering of historic data from both primary and secondary sources to build a context as focused as possible on the region that is now Camp Atterbury. This effort was conducted by the Principal Investigator with the assistance of CERL personnel at the local (Indiana) level in collaboration with the Principal Investigator. For instance, CERL personnel compiled census data and photographs.

Specific tasks included and proceeded generally as: (1) data acquisition; (2) analysis of historic documents and development of overview;

(3) identification of themes; and, (4) integration of themes with archaeological data that exists to date. Research continued up to and even after the draft report was presented.

The Internet allowed background and general information to be gathered prior to a focused archival research effort in Indiana. The webpages, search engines, and finding aides of major archives throughout the nation were searched using key words like: Bartholomew County, J ohnson County, Brown County, IN agriculture, Indiana rivers, mills, villages of Mt. Moriah, Kansas, Williamsburg, Edinburgh, and the Driftwood and Blue Rivers. The Indiana University-Purdue University Digital collections were especially helpful including access to previously published late $19^{\text {th }}$ and early $20^{\text {th }}$ century county histories. In addition, the following archival sources were visited either by the Principal Investigator, CERL assistant, or both:

- Indiana Historical Society

- Indiana State Library

- Indiana University Libraries and Archives

- Bartholomew Historical Society

- Brown County Historical Society

- J ohnson County Museum of History

- Camp Atterbury Environmental Office

- Thomas Cooper Library, University of South Carolina

- South Carolina State Library 
- South Caroliniana Library, University of South Carolina

- University of Illinois, Government Documents Library.

The archival research located maps, journals, diaries, census data, tax records and assessments, statistical records, land grants, and regional, county, and local histories and genealogies. Deed, plat, and estate records for the area were not researched as the Principal Investigator has learned through experience that the amount of time for such research versus the return is not cost effective. Secondary sources included journal articles, local and county histories, published and unpublished reports, books and dissertations.

\section{Study area}

Camp Atterbury was originally 44,500 acres and is now approximately 33,135 acres. For the purposes of this study, the original 44,500 acres will be included (Figures 2 and 3). As Figure 2 indicates, it includes most of what was historically Bartholomew County's Nineveh and Union Townships, a slight portion of northern Harrison County, the southern portions of J ohnson County's Nineveh and Blue River Townships, and a sectionwide portion of Brown County's Hamblen Township. The land was characterized by small farmsteads and a few small villages such as Kansas, IN. This boundary is, historically speaking, an artificial boundary based on the perceived needs of the U.S. Army at the time of acquisition. Importantly, it is not a boundary defined by a particular culture or geographic feature, nor did it have any meaning to the people who lived there, up until they were removed. Like many of the properties acquired as a result of the tremendous expansion of the Department of Defense during World War II, one of the prime reasons it was chosen was that the population in the area was quite sparse and fewer families would have to be displaced (Smith 1999; 2003).

Furthermore, like all Midwestern and many southern communities, Camp Atterbury was settled, organized, schooled, churched, policed, and adjudicated under the "county-courthouse" political system (Clendenen 1973; Newton 1974). Under this system of rural dispersed settlement, the population turned to a central place, the county seat, for governmental organization and many of their economic and social needs. Usually, the county seat was at or near the middle of the county. The traditional reason given is that it was believed that any man in the county ought to be able to reach the county seat in 1 day on horseback (Bailey 1991:25). Camp Atterbury was formed at the junction of three counties and on the fringes of each. 
The meaning of this is significant in that while Camp Atterbury families might have been neighbors on a daily basis, for certain societal infrastructural needs like schools, voting, taxes, and law enforcement, they would necessarily have had to turn away from their neighbors and outward to their respective counties - those in the northern part of Camp Atterbury returned to Franklin in J ohnson County, those to the east and south, to Columbus in Bartholomew County, and those along the western edge of the Camp Atterbury, to Nashville in Brown County. For the current project this makes the study of the area more difficult to accomplish, especially in revealing the cultural characteristics of the region. For instance, census data can reveal insights about the lives of citizens over a long-term basis. However, most readily available census data is at the county level and does not reveal specific insights about particular regions below that level. Occasionally, township data is available and useful. However, gaining insights into the lives of Camp Atterbury residents was extremely difficult since most of the historical document sources were expressive of county life, not Camp Atterbury life.

Interestingly, on a broad scale, the three counties that include Camp Atterbury also have noticeably different geomorphological landscapes. Camp Atterbury's location is a conglomerate of all three, from sharply defined valleys of Brown County, rolling hills of Bartholomew and flat prairie land of J ohnson County. The majority of Camp Atterbury is politically tied to Bartholomew County and perhaps culturally tied to the Upland South culture typical of settlers in the rolling hills of Brown County. The exact effect of these political and landscape differences are obvious avenues of research for the future. For the present, they can only be pointed out as hypotheses for future work. 


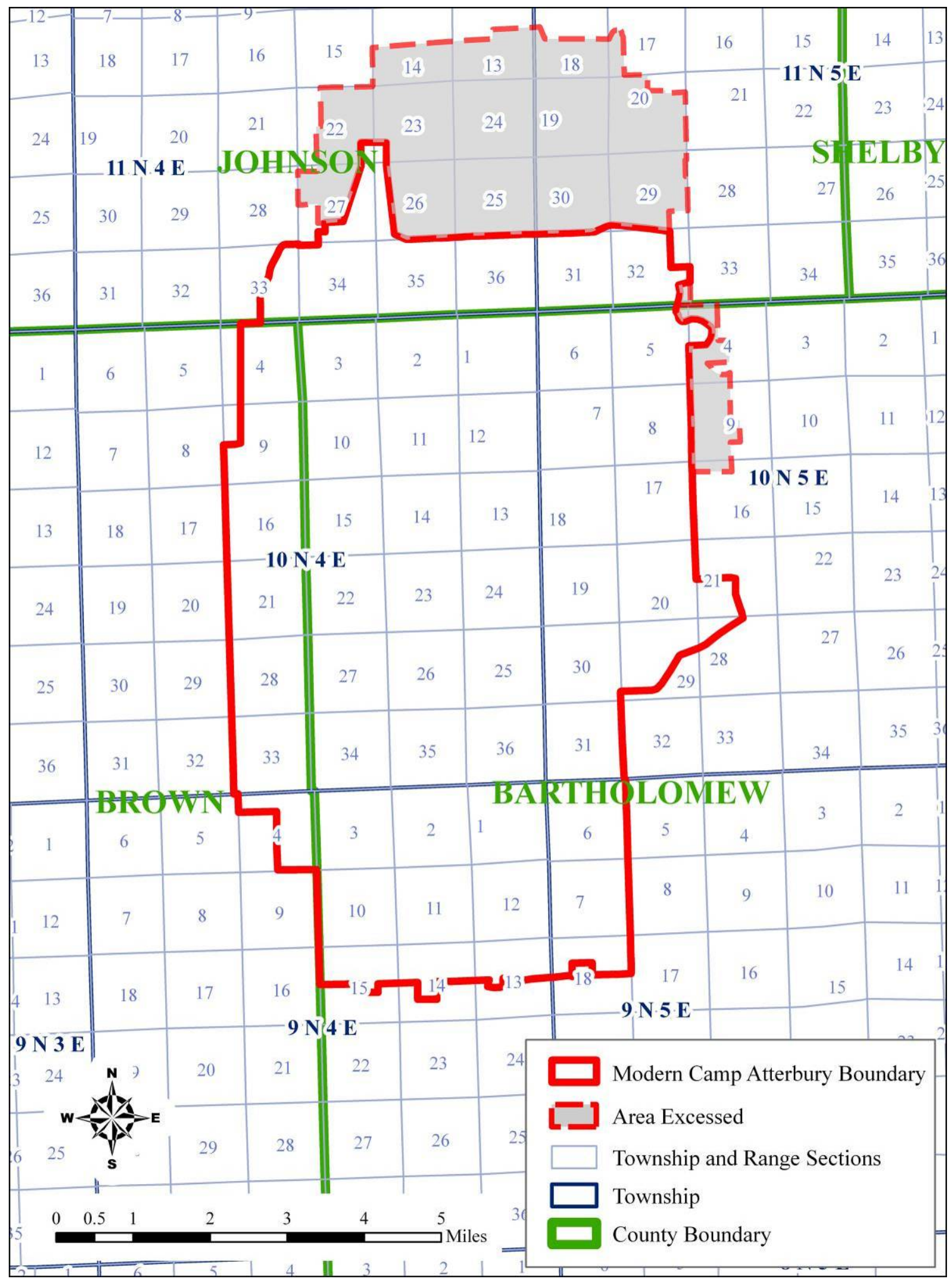

Figure 3. Camp Atterbury Joint Maneuver Training Center Township, Range, and Section map. 
Obviously important events, trends and influences occurred outside of this artificial boundary, but affected the lives and fortunes of those inside the boundary. Every effort will be made to focus on the lives of families within the boundary; however, this historic context will consider the broader settlement of western Bartholomew, southern J ohnson, and eastern Brown County as the study area. Readers are reminded that the Camp Atterbury encompassed two Nineveh Townships, one each in J ohnson and Bartholomew Counties. Every effort will be made to distinguish these two within the following chapters. Blue River Township is also significant; however, census data for Blue River becomes tied to the development of Edinburgh and blurs the data toward urban life after the 1870s.

\section{Project history}

This project was awarded 28 December 2008 and research began with a kick-off meeting at Camp Atterbury on $9 \mathrm{~J}$ anuary 2009. From that time until April 24, internet and interlibrary loan research was conducted by the Principal Investigator. From 27to 30 April 2009, the Principal Investigator conducted field archival research in Indiana and from that point until J une 30 the history was developed and written. Personnel from CERL assisted the Principal Investigator through research trips to the University of Illinois, Champaign, IL and Indiana State Archives, Indianapolis, IN. On 7J une 2009, the author was given the opportunity to visit with Camp Atterbury past residents during their annual reunion, which demonstrates a local interest in Camp Atterbury history. The reunion offers the potential for a considerable oral history of the region, which may be critical to archaeological interpretation of the region as there is very little written about the region during the period between 1920 and 1940. 


\section{Initial Occupation and Pioneer Settlement to 1870}

\section{The primeval landscape}

The settlement of Camp Atterbury was informed by its landscape. When Americans pushed west, most were farmers looking for rich soils, and those who were not farmers were often seeking their fortune through work that supported an agricultural community-millers, bankers, merchants, and blacksmiths. At the time of Euro-American settlement in Indiana, America was largely an agricultural nation. Some 69 percent of the U.S. labor force was engaged in agriculture in 1840, and 52 percent of the U.S. population lived on farms.* Thus, the key to Camp Atterbury's settlement history is its landscape and soils, which were shaped by its geology.

At the geologic foundation of the tri-county region of northwest Bartholomew, northeast Brown, and southeastern J ohnson counties-now Camp Atterbury - are bedrock shale, siltstone, and limestone, called the Bordon River Group and Rock Limestone by geologists (Howe 1997:8). This sedimentary rock near the surface dates to the Paleozoic Age, Mississippian Period, and is about 360 to 320 million years old. The geologic mass that became Indiana was at that time near the equator, mostly submerged beneath the ocean, and crinoids were the dominant life form. Eventually wind, water and glaciers eroded the bedrock creating the topographic landscape and soils found at Camp Atterbury today. Camp Atterbury lies across the margin between two dramatic landforms. The Wisconsinan glacial maximum cuts across the camp generally from the northwest corner at the J ohnson County line, dipping south to almost mid-camp, then returning northeast and then east to the eastern camp border (Figures 2 and 4). This line creates two distinctive landscapes. North of this line, Indiana's landscape is characteristically gentle and rolling, or "pleasantly undulating" (Fisher 1852:75). This is the result of successive glacial activity over millions of years, the latest being the Wisconsinan ice sheet only 10,000 to 16,000 years ago (Hedge 1997:195).

\footnotetext{
* See Growing Nation: The Story of American Agriculture, http://www.agclassroom.org/gan/timeline/1840.htm
} 


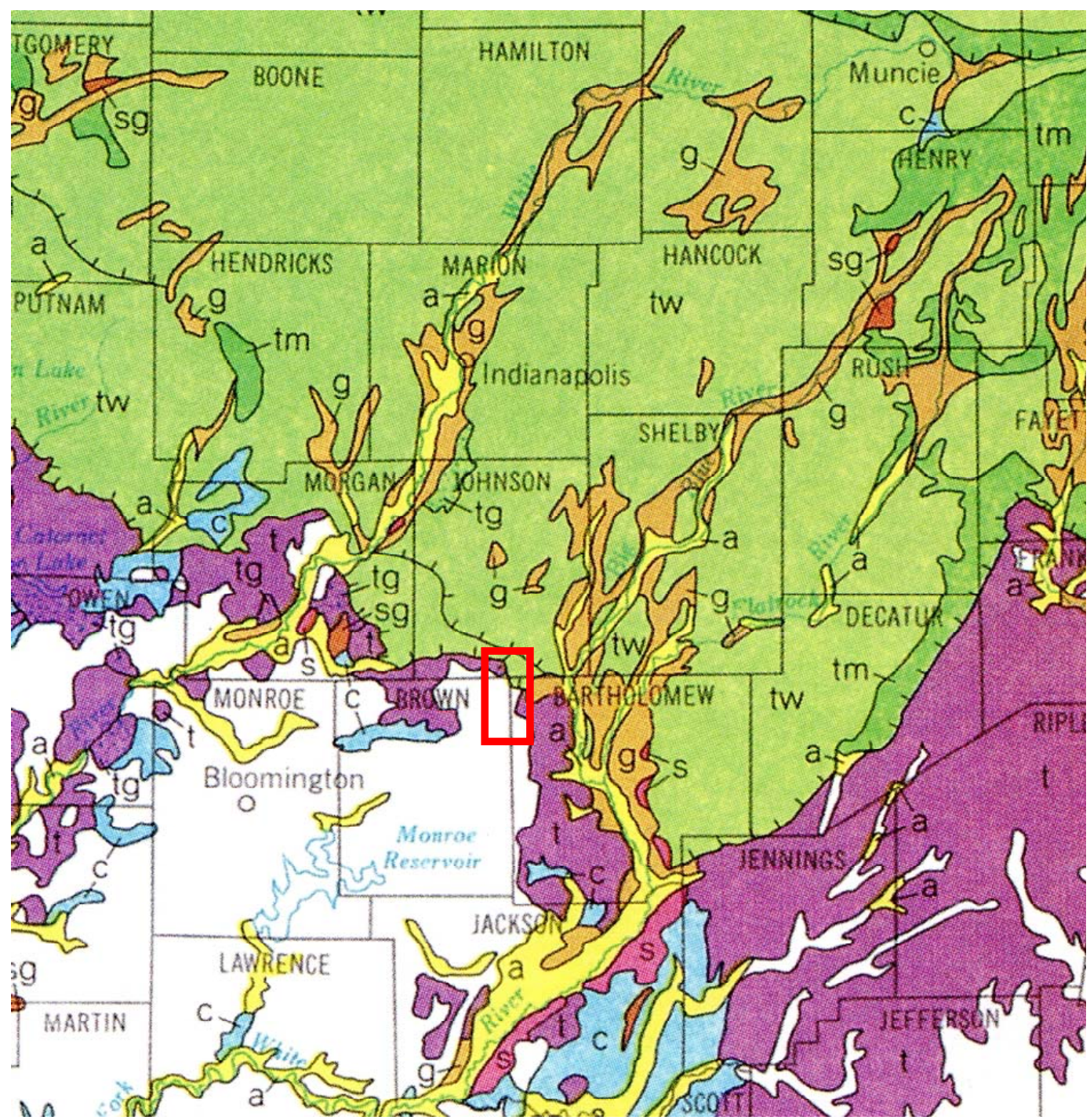

Figure 4. Close-up of Indiana glacial map. Green indicates Wisconsinan Glacial Maximum and Tipton Plain. White indicates limit of older drifts, purple till soils, orange sand and gravel glacial outwash. Red block location of Camp Atterbury (Indiana Geological Survey Map 26).

Being at the glacial maximum, the northern Camp Atterbury landscape is still slightly undulating, but with broad open flats, which anticipate the prairie flats to the north. Indeed, the landscape becomes flatter as one travels north, and eventually becomes monotonously flat north of Indianapolis, IN. This land, extending across the mid-northern part of Indiana, is called the Tipton Till Plain section of the Central Till Plain Natural Region, which is Indiana's largest natural region. Early settlers would find this land very attractive, containing deep rich soils, but often requiring drainage to be fully productive. D.D. Banta described southern J ohnson County's general topography from the county center:

From this elevated center, a gentle slope would be observed on both sides, in the northern part of the county; but, as it extended toward 
Brown County, the slope would appear more abrupt and precipitous. On the eastern side, this descent, in places, as in Nineveh Township, would be quite abrupt, making the boldly escarped hills of the township. ...To the east and south, would be stretched away, as far as the eye could reach, a broad, alluvial plain, covering the whole area of Clark, Needham and Blue River Townships (Banta 1888:462).

South of this line, and making up the majority of Camp Atterbury, the land is unglaciated, dynamic, and rolling with pronounced hillsides and steep valleys, which are the result of ancient eroding streams. An early description called the region "hilly and broken" (Fisher 1852:52). This land is the Highland Rim Natural Region. It runs narrowly from the Ohio River to Morgan County and at Camp Atterbury is referred to as the Brown County Hills Section (Homoya et al. 1985: Homoya and Huffman 1997:167). Part of the Hills Section was labeled the "Wall Ridge," which "trends to the north, through Union Township, thence west through Nineveh Township to the Brown County Line" (BaCHS, 1976:1).

It is not a continuous ridge, but a series of high points intersected by numerous valleys and gaps, that fall away to the lower lands of the east and west, north and south. The central and northern parts of Nineveh Township, while broken by outliers and foothills of the Wall ridge, are generally what may be termed rolling lands. Low hills and ridges, ranging from 25 to $50 \mathrm{ft}$ in height, occupy much of the country between the knobstone summit and the bottoms of the Driftwood, White River, and to the south of the ridge in Ohio and J ackson townships (BaCHS 1976:1-2). This land is more interesting and pleasing to the eye than the northern prairie section of Camp Atterbury, especially as the seasons change and the trees turn colors, but its soils were considered poor farmland. Explorer, land speculator, and State Representative J ohn Tipton, who played a major part in the formation of Bartholomew County, once described this land as "very poor hilly land, that does not, nor perhaps never will, admit of being tilled" (Tipton Papers Volume 1, quoted in BCHS 1976:193). Only the river valleys are fertile and the land was settled late in Indiana Pioneer history. It was never over-crowded and is more suited to recreation even today. Approximately two-thirds of Camp Atterbury is this kind of landscape.

Soils within the Tipton Till Plain Wisconsinan glacial maximum are loess over loamy Wisconsinan glacial till, and although they are poorly drained they are naturally highly fertile (Franzmeier 1997:45; Homoya et al. 1985:254; Homoya 1997: 158). Early champions of the soil called it "rich, 
black loam, mixed with sand" (Fisher 1852:75). Another noted that in Bartholomew County's Nineveh Township, "The surface is considerably broken; yet a good portion of it is nice rolling land and produces well" (Cline \&McHaffie 1874:357), obviously characterizing the margin. Surrounding Kansas, a small hamlet within Camp Atterbury, a 19th century historian described the land as "surpassingly fertile" (BaCHS 1976:177). Beyond the maximum to the south, the soils are discontinuous loess over weathered sandstone and shale. The Brown County hills land is "characterized by deeply dissected uplands underlain by siltstone, shale, and sandstone" (Homoya et al. 1985:261). The soils along the banks of Nineveh Creek were described in the 19th century as "Loess, a yellow or bluff-colored sediment. It has much siliceous material, but little coarse sand, and is easily removed by currents of water. The hills are accordingly cut into gullies and gorges, with abrupt sides" (Banta 1888:464). Indeed, bedrock is near the surface and water runs off the unglaciated thin soils in this area. Farming the hill slopes is possible, but it erodes what soils are there. Logging in the $19^{\text {th }}$ century exacerbated the erosion of these soils. The eastern edge of the camp includes moderately thick loess over weathered loamy glacial till and is not as fertile as those to the north (Franzmeier 1997:53). A mid-19th century promotional guide to Bartholomew County noted that the land was "not very rich, but is just the kind of soil to suit the horticulturalist. There is scarcely any other part of the State that is better adapted to fruit growing than the western half of this [Bartholomew] county ..." (Cline \& McHaffie 1874:133).

The extreme eastern portion of Camp Atterbury contains a sliver of another of Indiana's natural regions. This land is called the Scottsburg Lowland section of the Bluegrass Natural Region (Homoya 1997:158). This region, which makes up the gentle alluvial river valley of the Driftwood, has acid to neutral silt loam soils and the forest there consists of swamp cottonwoods, red maple pin oak, and river birch (Homoya et al. 1985:263). The Driftwood has a history of flooding. This area became known at the Hog Bottom region, a place where farmers allowed their hogs to fatten up for a few days on the abundant acorns, before driving them to Columbus for sale (Scott 1976).

Before the first European and American settlers, both the hills and flats of Camp Atterbury were thickly forested. On the camp's poorly drained northern end the flatwoods of the Tipton Till Plain consisted of a beechmaple-oak forest including pin, swamp white, bur, and Shumard's oaks, with green ash, American elm, sycamore and red maple (Hedge 1997:195; 
Hoyoma et al. 1985:255). The virgin forest trees here were described as "more than six feet in diameter, and their leafy tops were so interlaced that the sun never struck the ground" (Miller 1940: 359). Some areas, including most likely the land that is now Camp Atterbury, included shallow depressions that were seasonally wet. These areas are drained today. The hill region of the camp's southern portion is and was an oak-hickory forest of white, black and chestnut oak, black walnut, shagbark hickory, and wild cherry, with sycamore along the streams (Homoya and Huffman 1997:168). At the time of the first settlers, the forest consisted of "oak, hickory, beech, etc.," growing "luxuriantly" (Fisher 1852: 52). In hilly Brown County, the forests were described as "The timber on the hills is white and chestnut oak, hickory, etc., and in the bottoms walnut, poplar, sugar, hackberry, cherry, buckeye, elm, etc." (Fisher 1852:55). The understory consists of ferns, wildflowers, and under the chestnut oaks greenbrier, black huckleberry, blueberry, and painted sedge.

Camp Atterbury is primarily drained by creeks connected to the Driftwood River. This river is actually a branch of the East Fork of the White River that runs throughout southern and southeastern Indiana (Figure 5). North of the Driftwood, this long meandering drainage begins its two branching headwaters as the Big Blue River and Sugar Creek in Henry County. They come together to form a section of the stream that is called the Driftwood until it gets to Columbus, IN, in Bartholomew County. From there it joins the Flatrock River to form the East Fork of the White River, which then travels south and west to the junction of three Indiana counties, Knox, Davies, and Pike, all the way across southern Indiana. This long drainage finally ends along the western border of Indiana emptying into the Wabash River in Knox County. J ohn Vauter wrote of his trip in the New Purchase area in 1819, that "we found beautifully rich and level lands on both sides of the Driftwood, and well timbered. The river (by counting the horses steps) was 180 yards wide" where they crossed (Madison Republic, 16 February 1819 quoted in Branigin 1913:42). 


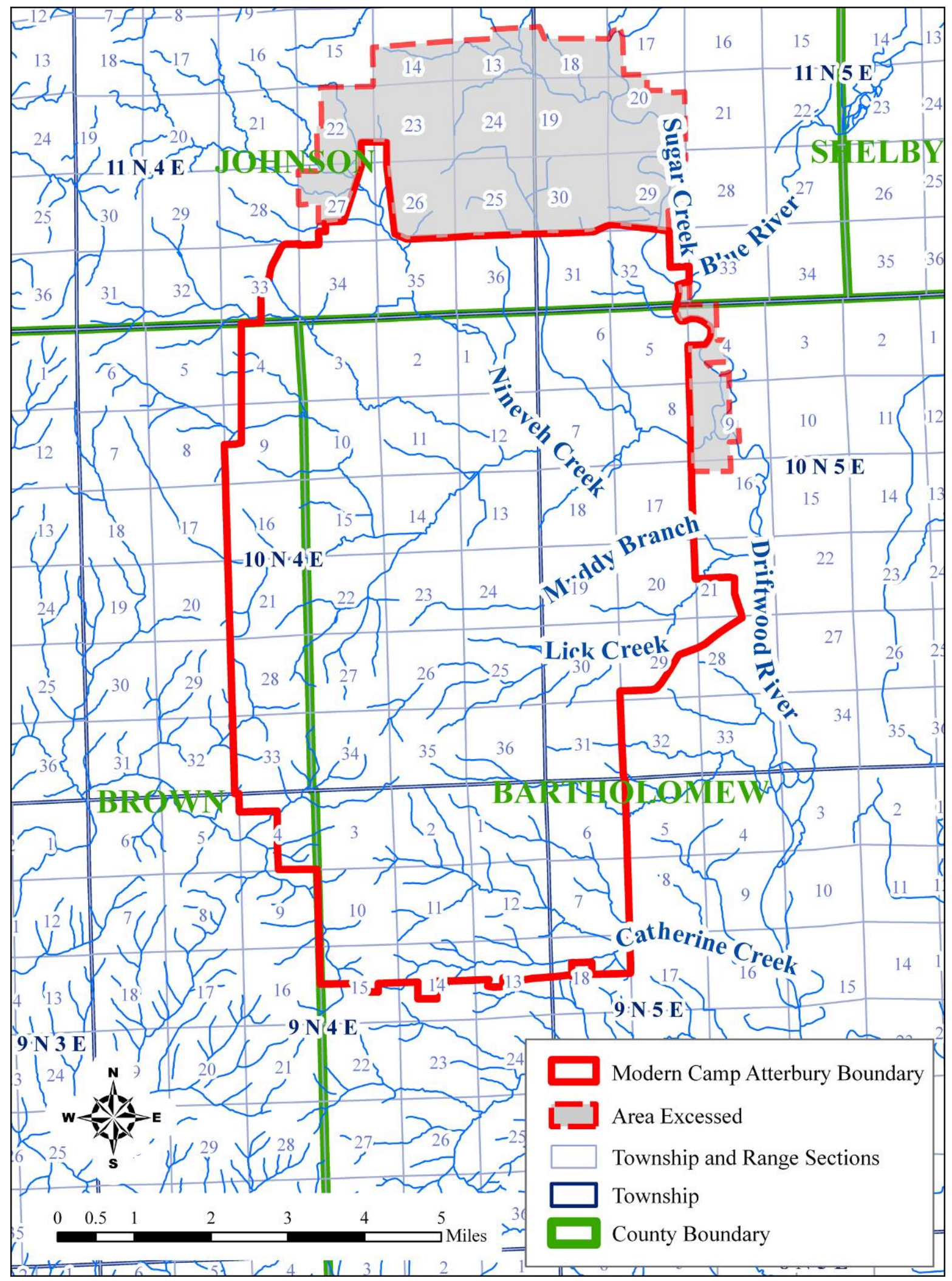

Figure 5. Principal creeks and rivers draining Camp Atterbury (courtesy Camp Atterbury). 
Camp Atterbury's northeastern corner includes Sugar Creek and the Driftwood, but most of the rest is drained by small dendritic creeks of the Driftwood watershed including north to south: Nineveh Creek, Muddy Branch, Lick Creek, and Catherine Creek. According to a promotional guide to the county, "Those streams and their tributaries furnish the [Bartholomew] county with a never-failing supply of stock water" (Cline \& McHaffie 1874:134). Nineveh Creek is the principal drainage in Camp Atterbury, and begins in J ohnson County. Banta notes that "from the southern and highest part of the ridge, Nineveh Creek sweeps down a narrow ravine, excavated by its plowing waters. Its channel is simply a gorge, with high and precipitous clay banks" (Banta 1888:463). Portions of the camp's westernmost region drain west to the White River out of East Fork of Sweetwater Creek. None of these creeks were in any way deterrents to settlement. However, flooding of the Driftwood, Sugar Creek, and Big Blue temporarily isolated the region on occasion, cutting transportation routes to Edinburgh, Columbus and Indianapolis.

Indiana's climate is and was well suited for agriculture. With dramatic seasonal changes, the climate is considered "temperate-continental and humid" and Camp Atterbury is, like its geographic position, at the margin between two climate zones. The first is a northerly cool-temperatecontinental (average temperature $48^{\circ} \mathrm{F}$ ) and the second is a southerly warm-temperate-continental (average temperature $57^{\circ} \mathrm{F}$ ) climate zone (Newman 1997:85). The Camp Atterbury average temperature is between 53 and $54^{\circ} \mathrm{F}$ (Newman 1997:86). In late spring central Indiana receives its greatest amount of annual precipitation. The state wide average is near 40 in., while around Camp Atterbury rainfall averages around 42 in. At Camp Atterbury, winter weather is confined to only 3 months and receives an average of $15 \mathrm{in}$. of snow, but there are wet cool springs, and a long hot summer growing season of between 170 to 180 days.

The vast south-central Indiana forests were full of game when the first settlers arrived. In describing J ohnson County, historian D. D. Banta noted "The county, as indeed all of central Indiana, abounded in a bountiful and variegated mast, on which the deers [sic], bears and wild turkeys fed and fattened in its season, and little wonder the woods abounded in game" (Banta 1888:344). J ohnson County also contained numerous salt licks, which attracted game and the early settlers learned to hide near them and wait for the deer to arrive. Deer provided pioneers with plenty of protein. Also, bear meat was considered especially "prized" and hunting them was assisted by dogs. Other animals that provided the early settlers with meat 
and hides included wolves, wild-cat, fox, otter, raccoon, ground hog, skunk, mink, weasel, muskrat, opossum, rabbit, pigeon, and squirrel (BaCHS 1888:45). It is hard to believe today, but at one time "as many as 100 wild turkeys comprised a flock, or drove. Enormous flights of passenger pigeons darkened the sky. For several years thousands of robins passed through Brown County in spring and fall. Robins and pigeons roosted low in the trees and at night were clubbed to the ground. They were salted and stored in barrels" (Bailey 1991: 72).

Wolves plagued the early settlers, attacking the pioneer's dogs and "with most incessant and terrifying howlings, rendered the nights hideous" (BaCHS 1888:45). Throughout the pioneer period, counties offered a bounty of as much as a dollar for every wolf killed (Branigin 1913:207). However, the most feared beast in the Indiana woods was the panther. "The bear, the wolf, and even the deer, would fight savagely when in close quarters, but each would run from the hunter whenever it could. The panther, on the contrary, was reputed to make battle with man without provocation" (Banta 1888:346). Wolves and panthers were supposedly eliminated in Brown County by the 1880s; however, the source of this statement also states that deer, turkey and bear also were eliminated (Bailey 1991:72). Meanwhile, for the early settlers, "More hunters, however, got into trouble with wounded deer than with all other animals of the country" (Banta 1888:346). Wounded deer were as dangerous as panthers.

One particularly bothersome creature was the squirrel. As D.D. Banta described, the forests were full of "mast" meaning nuts, which the settlers' hogs loved. However, this mast also meant an abundance of squirrels, and the rodents found the pioneer's crops a welcome diversion from their normal diet. Women and children were often sent to the fields to drive off the squirrels as the crops ripened, but they usually lost the battle. These tree rodents were such a pest to the early settlers that they became the focus of community gatherings. In the fall of 1834, for instance, settlers in Sand Creek and Wayne Townships of Bartholomew County held a match to see which township could kill the most squirrels within a 3-day period. Fifty hunters from each township competed, the official count being made by counting squirrel scalps, and the losing township had to provide a barbeque dinner for the other township. The winner was Sand Creek (by a head?). The final tally was not provided in the story, but one man alone was said to have brought nearly 900 scalps. Crows, more difficult to hit with a rifle, were also a problem and counted for two squirrels in the contest (BCHS 1888:46). 
The region seemed to be paradise for the early settlers, but some historians allow that the area was not without its detractions. D.D. Banta noted that early settlers found J ohnson County a "country where Nature was arrayed against them in one of her most forbidding forms" (Banta 1888:1). He quotes an early settler J udge Franklin Harden extensively:

Tall trees covered the whole country with their wide-spreading branches, descending to the ground, and the shrubbery below arose and united with the branches of the trees. ... In the open spaces, in the valleys, grew either prickly-ash or nettles both equally armed with sharp, fiery prickles. ... It was often necessary to cover the horses legs while plowing fresh lands to prevent contact with the nettles ... The soil, after a heavy rain, seemed to be afloat. ... Where the spice - wood did not grow too thickly, male fern formed a solid mass three feet in depth, covering logs and pitfalls so completely that the unwary walker often found himself thrown on his head beyond the obstruction. (Harden in Banta 1888:1)

Likewise, J ohnson County historian, Elba L. Branigin noted the forests' dense undergrowth:

Covered with a heavy growth of oak, poplar, ash, maple, sycamore, beech, walnut, elm and hickory, with spice brush and grape vines and undergrowth forming an almost impenetrable tangle, this wilderness was unknown even to the Indians except for occasional straggling hands of hunters or war parties bound from the villages on the upper Wabash to the Kentucky River (Branigin 1913:25-26).

Historian D.D. Banta adds that: "There were a few open spaces, 'nature's deadenings, and along the margins of the open swamps', where, 'wild grasses grew scantily in patches'”' (Banta 1888:334).

\section{Native Americans}

Perhaps this tangle of undergrowth was partially due to Native American's displacement from the area shortly before the first settlers' arrival. Certainly the first American settlers to Camp Atterbury were not the first to occupy the land. Native Americans roamed North America for 12,000 years before the settlers. The Native Americans probably managed the landscape with annual burning. Little is known about Native American use of the Camp Atterbury region, but the meager evidence suggests that they used it in a similar manner as the first settlers. That is, they hunted and gathered in the hills of Bartholomew and Brown counties, while the northern quarter of Camp Atterbury was used for both hunting and gathering 
and for permanent settlement. It is already established that the area had abundant hardwoods, and the Native Americans and early settlers both harvested the plentiful nuts seasonally available. There are over 170 separate archaeological sites testifying to the prehistoric occupation of Camp Atterbury (INARNG 2008). The majority of these are small lithic collections from projectile points and scrapers, indicating that most occupations were small temporary camps and that large habitations or villages were not prevalent in Camp Atterbury. This is probably due to a lack of large streams within the camp except for a short section of the Driftwood River, near Edinburgh.

The earliest peoples in North America were the Paleo-Indians (sometime prior to 8000 B.C.), and are known today as big game hunters. Archaeologists believe they had no permanent homes, but rather wandered across the landscape in a seasonal round following big game herds (Shott 2009:33). Many of their distinctive fluted projectile points are found on "river valley terraces" and at least one has been found within Camp Atterbury (Kari Carmany-George, personal communication 4 September 2009). Archaeologists call the period between 8000 B.C. and 1000 B.C., the Archaic Period, and it coincides with the retreat of the last major glacial episode and climate warming. Early Archaic points have also been found within Camp Atterbury, but it is likely that seasonal use of the Camp Atterbury region began around 4000 B.C. when the oak-hickory and beechmaple forests had been fully established over most of Indiana (Stafford 1997:361). From that time on, Camp Atterbury's landscape had abundant nuts and game. Native American camps at that time would have been small, temporary camps used to gather nuts and probably located on a small terrace next to Nineveh, Muddy, and Catherine Creeks.

Certainly, Native Americans were traveling through the area by the Woodland Period, beginning around 500 B.C. The Woodland period is traditionally marked by the introduction of ceramics, and some of the earliest ceramics are called "Marion-thick" as a result of being found initially in Marion County, north of Camp Atterbury (Stafford 1997: 363). The Woodland Period marked the beginning also of complex agriculturally-based societies, the remnants of which today are marked by mounds and other earthworks across the eastern United States. An example is the Hopewell complex at Mounds State Park in Anderson, IN (Stafford 1997:364). Within Camp Atterbury, Woodland ceramics have been identified on at least one archaeological site. 
Native American societies increased in complexity and size during the Mississippian Period (or Late Pre-Contact A.D. 1000-1450). At this time the central North American continent was the home of large permanent agricultural settlements like Cahokia, in Collinsville, IL. In Indiana, the Angel Mounds site, along the Ohio River, is an excellent example of such a town. The site consists of a large platform mound and over 100 acres of village. Perhaps as many as 1000 people lived at the town (Kellar 1983:5455). Testifying to local occupation, there was a Late Woodland site just south of Columbus, IN, excavated by Dr. J ames Kellar of the Glen Black Laboratory of Indiana University (BaCHS 1976:184). Closer to Camp Atterbury, $19^{\text {th }}$ century historian Branigin recorded two Indian mounds 2 miles north of the mouth of Sugar Creek (Branigin 1913:25). Furthermore, a little less than a mile north of the confluence of Sugar Creek and the Big Blue, archaeologists recently excavated a Late Woodland Period village about $2 \frac{1}{2}$ acres in size dating to the late thirteenth or midfourteenth centuries (Bush 2004:80; McCullough 2000). Archaeologists place this village within what they call the Oliver Phase of the Late Woodland-Mississippian Time frame. These people are described as "villagedwelling horticulturalists who inhabited the White River valleys of central Indiana from roughly A.D. 1200 until A.D. 1425 or 1450 in calendar years" (Bush 2004:1). While primarily horticulturalists, excavations at the site indicated they grew not only corn and beans, but also gathered hickory nuts, so it is quite obvious these Native Americans were making use of Camp Atterbury's forests.

J ust prior to the arrival of Europeans, Native Americans across the continent were in a state of flux. Large complex towns were abandoned and Native Americans resettled in dispersed farmsteads. Some archaeologists believe the collapse of these great societies was the result of climate change, causing a change in the growing season. Another reason may be an increased availability of bison herds, drawing people westward. Or perhaps Native American's simply over exploited the natural resources (Trubitt 2009:45). The introduction of European goods flowing from colonial settlements along the coast and the St. Lawrence-Great Lakes waterway also created turmoil among the Native Americans in Indiana, creating tension and competition among the tribes, notwithstanding the diseases that also took their toll (Noble 2009:52). In any case, by the time Native Americans had direct contact with Europeans, there had been tremendous displacement. Then new diseases and warfare decimated the Native population further. Experts have estimated that during the fifteenth century, as many 
as 200,000 Native Americans were living in Indiana. By 1700, there were only around 20,000 (Parker 1997:370).

J ust how much 10,000 years of Native American occupation modified Camp Atterbury's landscape is unknown, but it is now well established that Native Americans conducted seasonal burnings to clear vegetation, create habitats for game species and opened the forest for settlement (Parker 1997:369-370). They also created trails that were used by the first European and Euro-American explorers and settlers. There is little doubt these land management practices took place in the Camp Atterbury region and that Native American displacement changed the landscape prior to the first Euro-American settlers. There is evidence that central Indiana, between the Ohio and the White Rivers was "generally avoided" by historic Native Americans (Madison 1986:10). As mentioned this might have resulted in the "impenetrable tangle" in southern J ohnson County (Branigin 1913:25-26).

\section{The arrival of the Europeans}

The French were the first Europeans to arrive in Indiana, the traditional "first" honor being given to explorer Robert Cavelier de La Salle in 1608 who was looking for the gateway to the Mississippi River (Madison 1986:12). After La Salle, French traders and soldiers arrived from the St. Lawrence River in the early seventeenth century (Nassaney 2009:45). Their primary goal was fur trading, but there was also a desire to convert the Native Americans to Christianity. To facilitate both, the French constructed a chain of trading posts linking the St. Lawrence to the Great Lakes and the Mississippi River. Among the many posts was Fort Ouiatanon, constructed in 1717, located along the upper Wabash River, in Tippecanoe County, IN. Other posts included the Indian village of Kekionga (Fort Wayne) and Chippecoke (Vincennes). All three were along Indiana's major waterways. Vincennes was home to the first settlers (as opposed to traders and soldiers) in the state (Parker 1997:370). Once the English along the Atlantic coast began drifting over the Appalachians, the French fortified these posts. There also may have been a small French trading post south of Camp Atterbury along the East Fort of the White River, at Vallonia, in J ackson County. If so, traders may have made their way north along the Driftwood River and may have been the first whites to visit the Camp Atterbury region (BaCHS 1976:41).

When the French established their trading posts, Native American groups in Indiana included the Miami, Potawatomi, and Delaware in strength, 
with a host of other smaller tribes including the Shawnees, Weas, and Wyandottes (Figure 6), which were also only recent arrivals. These tribes were reoccupying lands abandoned by the collapse of the Iroquois Confederacy, which had dominated the region just prior to the arrival of the Europeans (Madison 1986:10). Some came from the west, but most were eastern tribes. These new tribes set themselves up as middlemen between the French and more western tribes. They lived a life very similar to the Late Woodland peoples, occupying medium-sized villages in the summer, and dispersing into small kin related camps in the winter (Edmunds in Parker 1997:369), but their lifestyles and fortunes changed rapidly as they became entangled in the conflicts between the French and English for the North American continent between 1689 and 1763.

Indeed, throughout the eighteenth century and into the early $19^{\text {th }}$, Indiana became a military and economic battleground between the French and English and later between the Americans and English. The Indiana tribes were drawn into conflict through various alliances. In the 1730s, for instance, the French encouraged the Indiana tribes to invade the English backed Chickasaws living in the South.

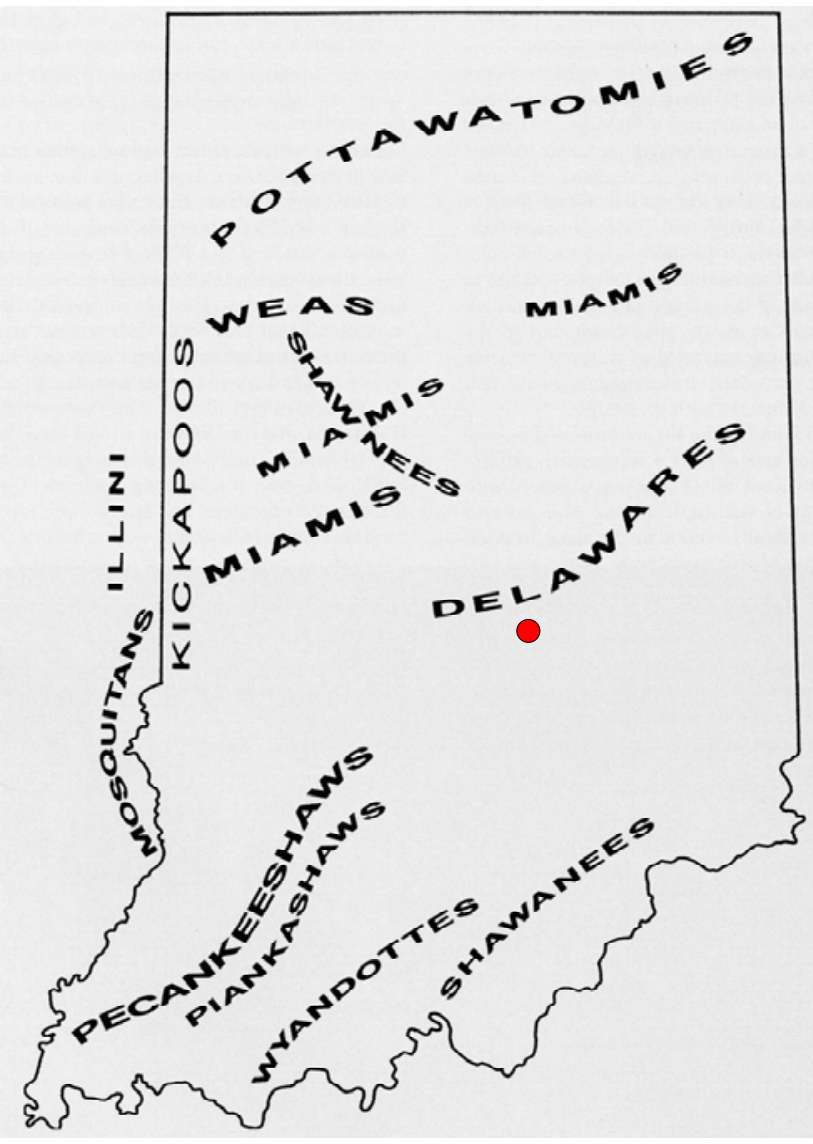

Figure 6. Historic Indian Tribes at the time of initial settlement, ca. 1800. Approximate location of the Camp Atterbury in red (Courtesy Jackson 1997:368, modified from map by Daniel Hough). 
This ended in a rout of the Indiana tribes (Madison 1986:13-16). Meanwhile, Pennsylvania traders enticed the Indiana tribes toward their cheaper trade goods and in 1747, Piankeshaw Chief La Demoiselle, established a trading village at Pickawillany along the Ohio River (Piqua, Ohio) to better access the English trade.

The French responded by destroying the village in 1747 and constructing Fort Duquesne in 1754 at the forks of the Ohio (Pittsburgh, Pennsylvania), demonstrating their resolve to protect their North American empire. Soon France and England were at war. The British captured the French forts, including Ouiatanon, which were recaptured by the Miamis and Potawatomis during the Pontiac Rebellion of 1763.

That same fateful year, the French gave up their claim to the land that became Indiana (Madison 1986:18) and later in the year the British issued a Proclamation that the land west of the Appalachians was closed to American colonists. Nevertheless, the proclamation had little effect, and during the rest of the 1760s, Americans illegally seeped through the mountains seeking land to farm or to sell in the future.

As land explorers, speculators, and squatters continued to trickle westward in the 1760s drifting down the Ohio or through the mountains into Kentucky, some undoubtedly entered Indiana. Possibly one or two families ranged up the East Fork of the White River and onto the Driftwood, but it is unlikely that any actually settled in Camp Atterbury. Still, as will be noted, an old Indian trail did lead up the west side of the Driftwood, so it is possible that a few adventurous settlers made their way through the otherwise vacant land. Most of the activity was along the Ohio and up the Wabash. One of these settlements was the English Fort Sackville, formerly the French Vincennes.

In 1774, the British reinforced their resolve to protect their northern empire by enacting the Quebec Act, a declaration that the territory north of the Ohio was part of the Province of Quebec and that Americans were excluded from settlement (Madison 1986:21). As tensions rose between the Americans and the British, the Native Americans were again used by both sides, but the British were better at providing food, guns, and supplies. From Detroit they began encouraging the Indians to attack Americans in Kentucky. The Americans responded by organizing an expedition against the British forts along the Mississippi and Wabash river including Fort Sackville, IN. Under the command of George Rogers Clark, who captured 
Kaskaskia along the Mississippi, Captain Leonard Helm led a detachment against the French village at old Vincennes along the Wabash. Helms was in turn captured by British General Henry Hamilton, and in a daring winter raid, Clark recaptured Fort Sackville in 1779 (Madison 1986:25-26).

In 1781, the fate of the Native Americans in Indiana was sealed when the British surrendered at Yorktown and America gained the territory. Although it would take another war between the Americans and the British in 1812, it was only a matter of time before the Native Americans were forced out of Indiana and the land was open for American settlement. Still, the large tribes of Delaware, Potawatomi, and Miamis remained in the New Purchase area until around the 1830s. Furthermore, although the last removal of Miamis was not until 1846, even then only half the tribe moved. Today, descendants of those Miamis that did not move still live in Indiana. Locally, one of the earliest settlers in Bartholomew County, J ohn Hamner who settled in Sand Creek Township in 1819, remembered that there was a village of 40 Potawatomis at the fork of Sand Creek and there were "numerous wigwams on each side of the Driftwood and on up Blue river at that time" (BaCHS 1976:183). If so, there is a possibility that there was a historic Native American settlement in Camp Atterbury.

\section{Initial settlement of Camp Atterbury}

By 1800, Indiana was part of America, and part of a vast territory called the Northwest Territory consisting of all the land west of the Appalachians, north of the Ohio, and east of the Mississippi. It was a land that most Americans felt was theirs as a result of wining the American Revolution. After the Treaty of Paris in 1783, while the new American government debated what to do with the land, and armies made expeditions into Indiana to fight the Indians and British, a steady flow of settlers were floating down the Ohio or crossing the Ohio from Kentucky in an effort to settle the land. Meanwhile a series of government policies were passed that would turn the flow into a flood. These policies included the Ordinance of 1785, which laid out a system of surveying the land for legal purchase and the Northwest Ordinance of 1787, which set territorial and later state governance. There was also the Land Act of 1800, which reduced the minimum amount of land required to make a purchase.

This land act promoted settlement of the land as opposed to land speculation and also created the Indiana Territory (Madison 1986:33-35). Once the Indiana Territory was proclaimed, a series of treaties incorporated more and more of what is now Indiana (Figure 7). The creation of the Illi- 
nois Territory in 1809 established the present boundaries of what later became the state of Indiana (Branigin 1913:27). Statehood was established in 1816 and the New Purchase of October 1818 opened the floodgates to the settlement of the Camp Atterbury area. The New Purchase was part of the Treaty of St. Mary's, in which the Delaware and Miami Indians relinquished the center part of the Indiana territory to American settlement.

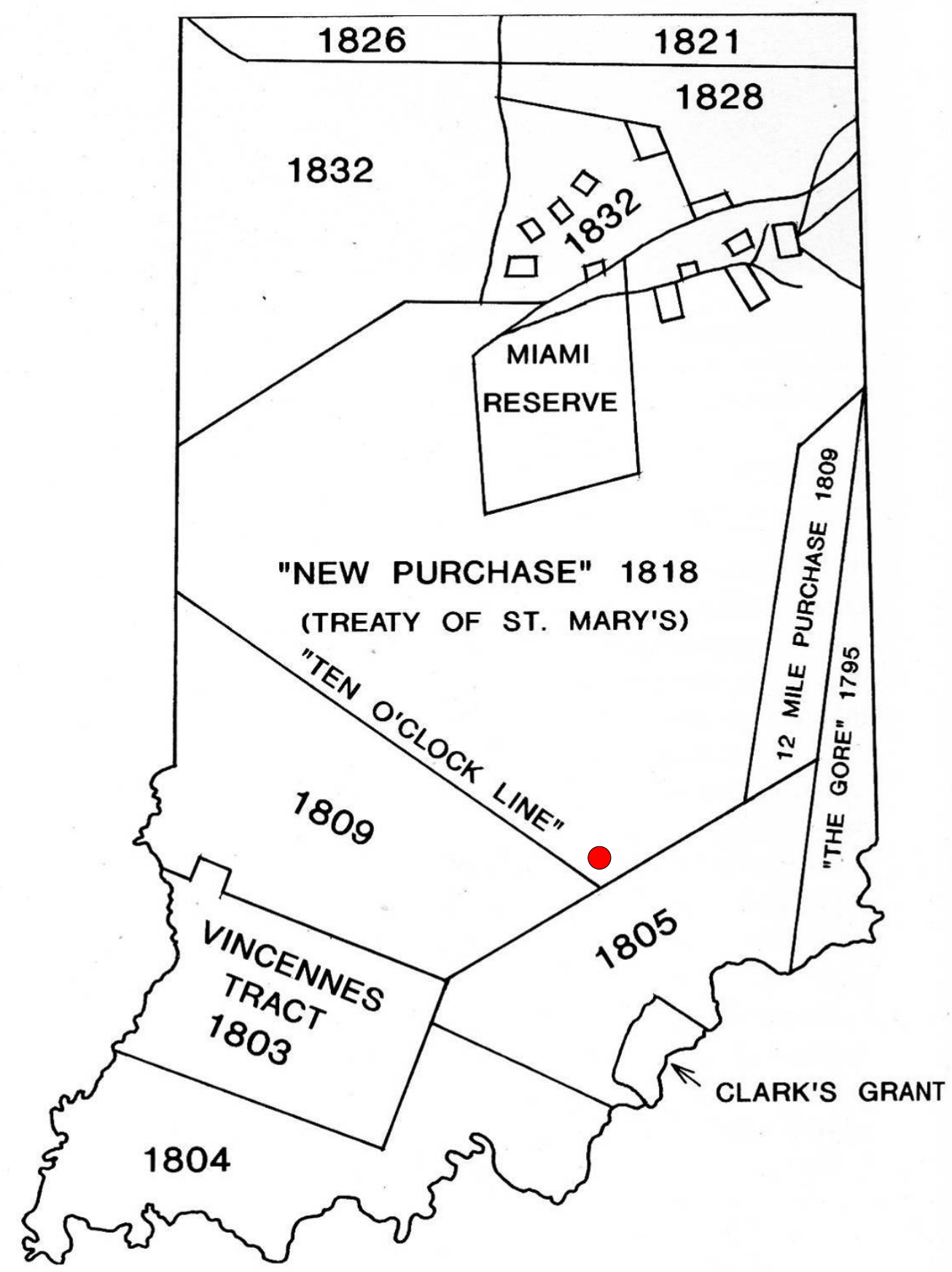

Figure 7. Succession of Indian treaties incorporating modern Indiana. Approximate location of Camp Atterbury in red. 
The first wave of Euro-American and later American settlers was part of a "trans-Appalachian migration process that predated the American Revolution" (Nicholson 1992:7). Most were white, small scale farmers with few possessions who came with their livestock and little else. Usually they were squatters, far in advance of formal government and even U.S. ownership of the land. Often they came from the mid-Atlantic states, moved into Tennessee and Kentucky, but were always ready to take advantage of any opportunity to move on west or north to Indiana. From 1810 to 1820, when Indiana became a state, the white population increased almost by 500 percent (from 24,520 to 147,178) (Parker 1997:370). Most of this population was confined to the 18 counties in the state's southern portion, south of Camp Atterbury. They were concentrated around the old settlement of Vincennes along the Wabash, and along the Ohio from Cincinnati to Louisville, KY.

An unknown number, especially after the New Purchase, made their way into central and northern Indiana from the settlements along the Ohio River and using Indian trails from the new state of Ohio. A tour of central Indiana just after the New Purchase found two squatters between the Sand Creek at Geneva in J ennings County and the site of Indianapolis. One was located along the Blue River (BaCHS 1976:41). J ohnson County historian D. D. Banta noted that the legal settlers arriving in 1820 occasionally bought lands "on which cabins had already been built by earlier settlers" (Banta 1888:3236). Only a year after the new purchase, the public lands of future Bartholomew County were surveyed and placed on sale at Brookville and J effersonville, IN (BaCHS 1976:43). With the land surveyed, the invasion of legal settlement began in earnest around 1819. The settlement of Bartholomew and J ohnson Counties was invigorated in 1820 by the government lowering of the price of land to $\$ 1.25$ an acre and the minimum purchase to 80 acres (Salstrom 2007:39).

Perhaps the first Americans to enter Camp Atterbury were part of a military expedition against a Delaware Indian village on the west fork of the White River above present day Indianapolis. In 1813, General J oseph Bartholomew (the county namesake) led about 137 men from Vallonia in J ackson County to attack the village. Their route passed along the east side of the Driftwood. On the return trip they passed down the west side (Pence 1896, reprinted BaCHS 1976:185). J ohn Tipton was among these men and soon returned to claim land in the county. Another possibility might be William Conner, a trader who ranged about central Indiana and built a post at Connersville, IN. In 1816, he is known to have floated down the 
Flatrock River with trading goods (BaCHS 1976:41). An excellent summary of the initial settlement of Indiana, including Camp Atterbury is presented by George Parker:

The first wave of settlers were transients on the land. They "squatted" on unsold lands, built cabins, cleared a few acres of corn and vegetables, and subsisted largely on wild animals. As the country became settled, these frontiersmen would sell out to the next wave of settlers and move farther out into the wilderness. The first settlements were along the forested river valleys, where transportation was easiest. ... Farms expanded away from the stream valleys as the population increased and road systems improved (Parker 1997:373).

Banta noted that the initial settlers often visited the land and decided where to settle, then purchased the land at the land office, and finally brought their families to their new purchase. Others settled and waited for a land office to open. The land office in Brookville opened on 4 October 1820. Like many other settlers, J ohn Campbell (Edinburgh's first settler) returned east to purchase the land he had already settled (Otto 1987:2).

J oseph Cox is given the traditional honor of the first settler to Bartholomew County. Actually, he was the head of a large contingent that included his wife, nine sons and four of their wives, and several grandchildren. They came from J ennings County in 1819 and settled just northeast of modern Columbus along Hawcreek (BaCHS 1976:197). J oseph's son Thomas constructed a grist mill, a wise move that would attract other settlers and provide a solid economic base for the family.

The story of the Cox family is so archetypical of Indiana pioneers, and most likely those of Camp Atterbury, it is worth examining in greater detail. Although Cox was born in Pennsylvania, his family first settled in North Carolina. When he became an adult he moved first to Virginia, and then seeking land, moved to Knox County, KY. He raised his family along the Cumberland, was thrown out of the Quaker church for Indian fighting, and then decided to follow his restless brothers who were making for Missouri. Once across the Ohio his wife became ill and he settled in J ackson County, IN. Three years later, the New Purchase lands opened for settlement, and he sold his land in J ohnson County for the large sum of \$10.00 an acre to move north to Hawcreek, 18 miles from his J ackson County home (BaCHS 1976:197-198). Cox probably never understood how typical his migrating lifestyle was at the time. Countless others were on the move from Virginia and North Carolina into Kentucky, settling a few years and 
then moving farther west. The flow of migration channeled these people to the Ohio, when they crossed at the falls of the Ohio, Madison, Maukport, or Henderson (to name a few) to settle for a few years in Indiana. Many did indeed move on to Missouri (Smith 1993), but for many others, sickness, death, or new opportunities for land drew them farther north into central Indiana to make a final homestead. For agriculturalists, it would be a good move and many of them became quite prosperous.

Another Hawpatch settler was less fortunate, and became one of Brown County's earliest settlers. J ob Hamblen also began his journey to Indiana from Virginia. Like Cox, his first move west was to Knox County, KY around 1816 or 1817. He is thought to have moved from there to J ennings County. By 1821 he settled in the Hawpatch, northeast of Columbus where he intended to remain. However, he did not have the money to buy property and was removed by the settler who had purchased Hamblen's land and he had no legal recourse but to move. After a settlement of a horse and other items for Hamblen's land improvements, Hamblen moved to the western edge of Bartholomew County, Section 30, T 10N, 4E, (now Brown County) and started over. This location is just a mile west of Camp Atterbury's western boundary. J ob's son eventually purchased this property and the Hamblen's were rewarded with the township being named for J ob as the area's traditional first settler (Hamblen 1940:66-70). J ames Taggart, though, gets the nod as the first to purchase land in the township in 1828. His property was just a mile south of Hamblen's and later a small hamlet was named after the family (Ford n.d.:43).

It was the eastern portion of the Bartholomew County that drew the earliest settlers. One county history states that the southwestern part of the county and the land "lying contiguous to what is now Brown County" was not settled until the 1830s (BaCHS 1976:43-45). The land in eastern Bartholomew County was fertile and gently rolling rather than "broken" as has been described on the western side that is now Camp Atterbury. Areas called the Hawpatch, along Haw Creek, Sand Creek, and Flat Rock were favorite locations, as well as land close to the Driftwood. Many of the first land purchases were by speculators, buying up the best lands to sell to homesteaders.

While the Hawpatch filled up, other settlers arrived in the future southern J ohnson County and Camp Atterbury. The Blue River and Sugar Creek were obvious points of interest to the first settlers and J ohn Campbell claimed the honor of the first settler of Edinburgh. Campbell took a 
slightly different route to central Indiana, from Tennessee in 1814 to Ohio, then to Connersville, IN, and from there to the Blue River in 1820 (Otto 1987:1). On the final leg, he had to cut his own trail, with the help of a friend and neighbor Benjamin Crews. Crews settled a little south of Campbell and became one of the earliest settlers in Nineveh Township, Bartholomew County (Otto 1987:2).

As frontier trails were built the pioneer's options for migrating into the tricounty region increased. In 1845, representatives of a group of about 15 families in Tuscarawas and Coshocton Counties, Ohio took the traditional route down the Ohio River to Madison and then traveled north along the Madison / Indianapolis road to Nineveh Township where they purchased land along the Wall Ridge in Union and Nineveh Township. Then, they returned home, gathered up their belongings, and wagon-trained across Ohio to Indianapolis via the National Road. There they turned south on the Madison road to Taylorsville and then settled on their new land, which became known locally as the Ohio Ridge settlement. The Ohio Ridge settlement is now within Camp Atterbury (Stott 1972).

Although historian Banta claims that settlement of J ohnson County was slow, other evidence would challenge that assertion (Figures 8 and 9). For instance, while Banta states that at the end of the year of 1820 there were only 20 families in J ohnson County (Banta 1888:326), Otto states that before the close of that same year, 39 land purchases had been made in southern J ohnson County totaling 4000 acres. If both statements are accurate, then it is possible this information provides a glimpse of the ratio of settlers to speculators, at around 1 to 1 . Still, progress in settlement was made. At the end of the following year, "a line of settlements extended nearly across the south side of the township. In 1821, Amos Durbin, ... settled on the outskirts of Blue River Settlement and found himself in Nineveh Township. Durbin is recognized as the first settler in Nineveh Township [J ohnson County]" (Otto 1987:4). Durbin was followed that same year by Ohioan Robert Worl, who "erected a pole cabin on the [Nineveh] creek bank 1 mile east of the present village of Nineveh" (Hibbs 2007:7). This land is also within Camp Atterbury.

\section{County formation}

Both Bartholomew and J ohnson Counties were established by land speculators. In J ohnson County, George King purchased land he thought was a good location for a county seat (and later became Franklin, IN) and then worked to petition the state for county organization (Banta 1888:681). The 
Indiana legislature passed the act in December 1822. Blue River and Nineveh Townships, J ohnson County were formed in 1823 (Banta 1888: 683). In Bartholomew County, J ohn Tipton played a prominent part in the early history of Indiana as a soldier, state representative, U.S. senator (18321839), Indian agent, and of course, land speculator. Tipton, who had passed through the area during the War of 1812, later purchased land and donated 30 acres to the county for the county seat under the condition the town be named for him. Bartholomew County was created by the state legislature in J anuary 1821 (BaCHS 1976:193). The local authorities did at first call the county seat Tiptonia, but quickly renamed it Columbus (Baker 1995:101). Nineveh Township, Bartholomew County was originally organized on 10 May 1824 (BaCHS 1976:34). On 3 J anuary 1837, the township had to be reformed as a result of the creation of Brown County. Then on 3 September 1845, 12 sections were taken from it to form Union Township. From 1845 on, the township boundaries remained consistent until the creation of Camp Atterbury (BaCHS 1976:34, 36).

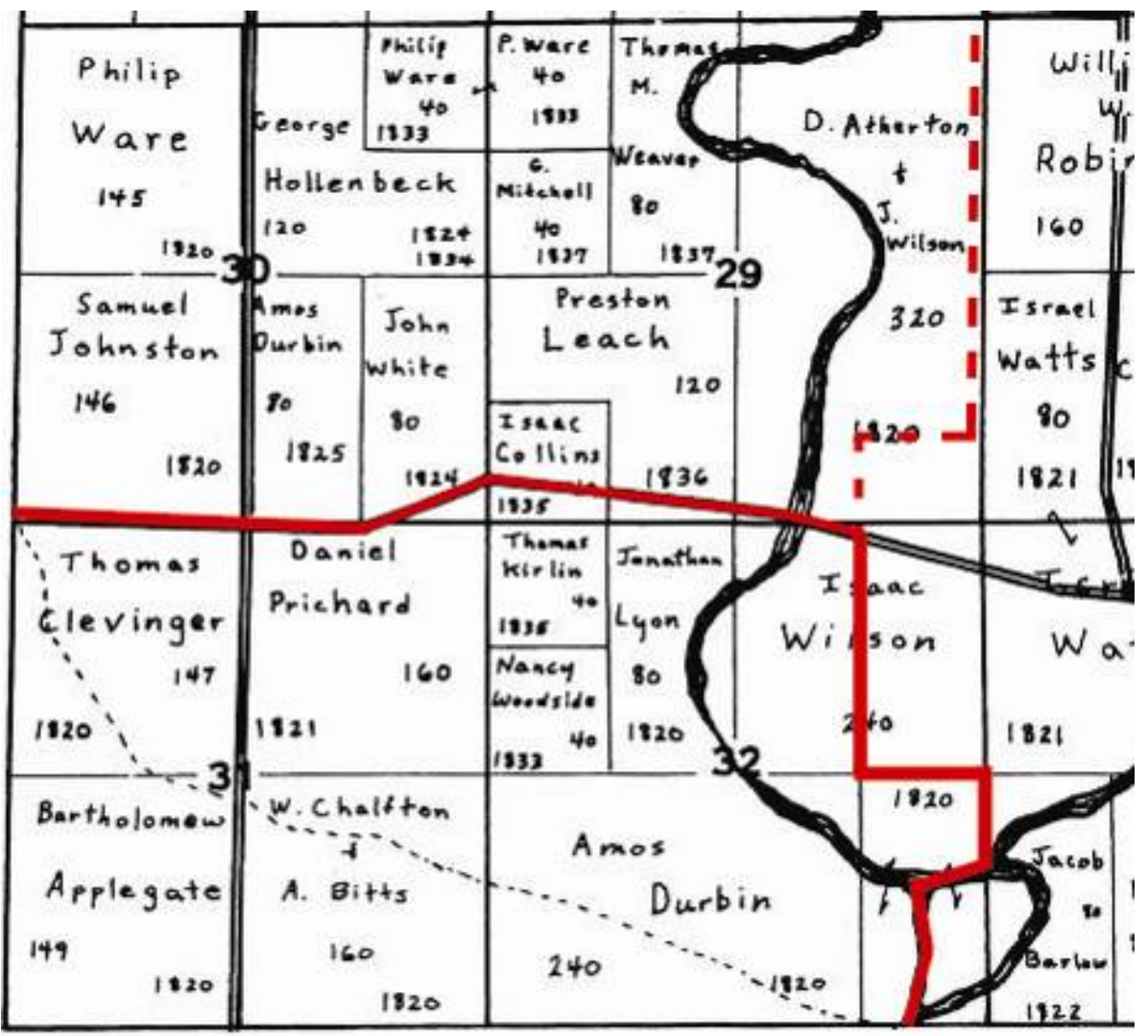

Figure 8. Portion of a map of land purchases, Blue River Township, Johnson County, IN, 1820-1850 (courtesy Atlas of Johnson County). 


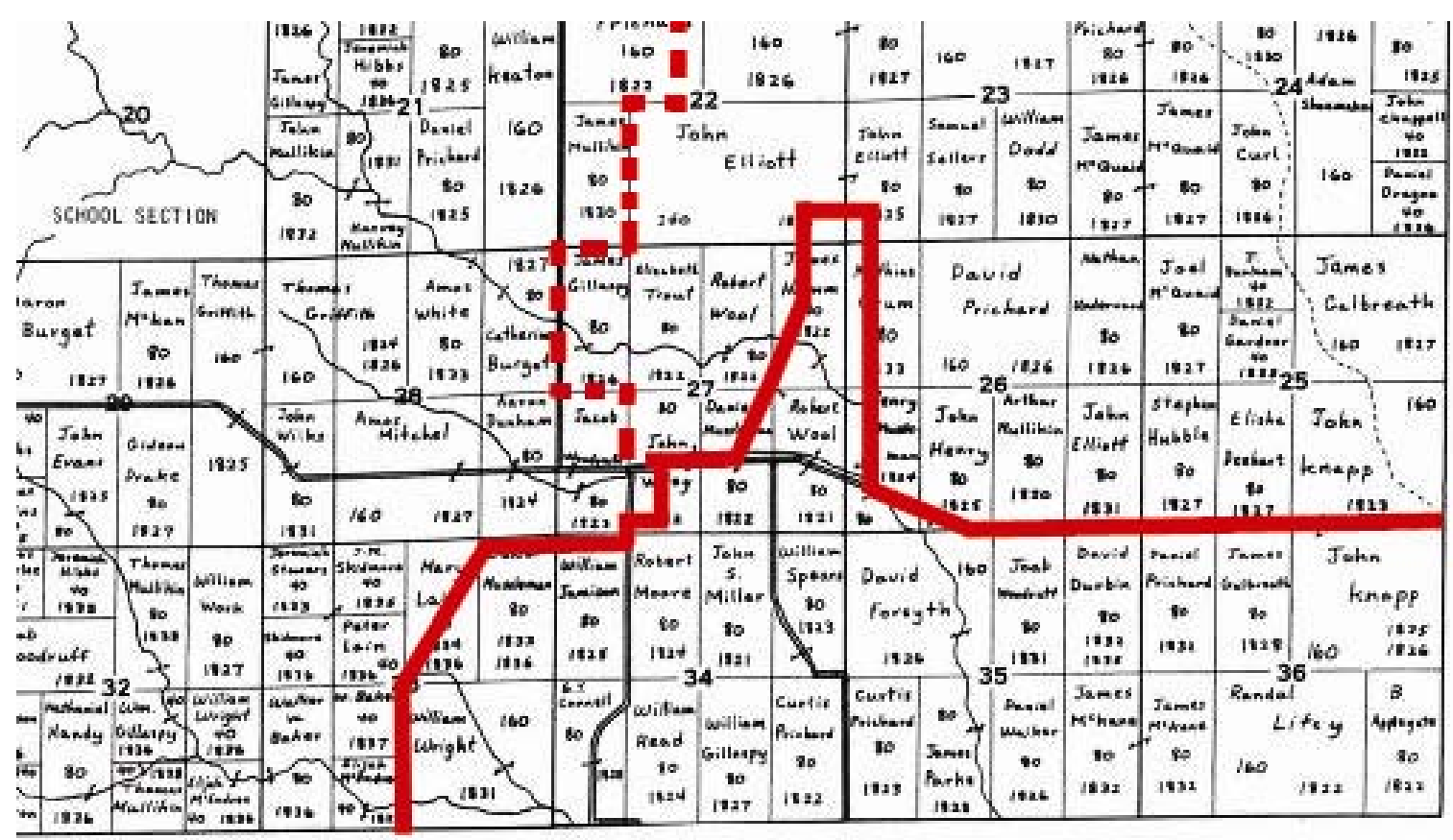

Figure 9. Portion of a map of land purchases 1820 to 1850 in Nineveh Township, Johnson County (courtesy Atlas of Johnson County).

Brown County was established in 1836 (Bailey 1991:25). The hilly region between Columbus (the Bartholomew county seat) and Bloomington (the Monroe County seat) had acquired a reputation as a refuge for less respectable citizens. Several prominent citizens in the area, including the Brummetts, Dawsons, Taggarts, and Hamblens, petitioned for the creation of Brown County (Nicholson1992:39-41). Prominent citizens in Bartholomew County wanted to rid themselves of the "ruffians and thieves" who were "prone to violence" and supported the petition (Nicholson1992:37). The location of the courthouse, again, had both a geographic and economic origin. The committee of county commissioners requested bids from three central Brown County communities (Georgetown, Hedgesville, and Salt Creek). Banner Brummett and J ames Dawson won the bid, and J acksonville, renamed Nashville, became the county seat (Nicholson1992:42-43).

\section{Trails, roads, and railways - entering Camp Atterbury}

The general migration route into the Indiana Territory was down the Ohio River and into the northern interior from Madison, the falls of the Ohio (Louisville, J effersonville), Mauckport, or Evansville. For the very first squatters, trappers, and soldiers, the Wabash River provided the most convenient route, and for that reason, the first Europeans and Americans probably entered the Bartholomew-J ohnson County region by coming up the White River and its East Fork to the Driftwood River. The earliest set- 
tlers followed the old Indian trails, and cut their own roads to settle central Indiana. Some migrated west from Ohio along such trails.

From the Ohio River, two roads, most likely originally Indian trails, were the main pathways for the earliest settlers to Bartholomew and J ohnson Counties. These roads were the Mauxferry road and the Madison road (Figures 10, 11, 12, and 13). Mauxferry Road (also Mauk and Mock's) officially became a state road in 1825, but there was likely an old trail from the ferry crossing at Maukport through Corydon (the territorial capitol) to Salem, Brownstown, and Rockport. From there the road ran along the west side of the Driftwood River past Franklin to Indianapolis (Pence n.d. Columbus Republican). In Bartholomew County, this portion of the Mauxferry road was used by General Bartholomew's militia on their return trip after defeating a village of Delaware Indians along the White River. They crossed at the "upper rapids [sic] where Lowell mills would be later established, 4 miles north of Columbus" (Pence 1895 in BaCHS 1976:191). Another expedition was organized in J uly of that same year and probably followed the same route north. Among the soldiers was J ohn Tipton who would later travel the trail in 1820 with commissioners seeking a location for a new capitol of Indiana. Tipton stopped along the trail at a ferry across the Driftwood River run by Richard Berry just south of what became Edinburgh. He later surveyed this road in 1823 (Pence 1896 in BaCHS 1976:186). This section of the trail was called the Berry Trail (Otto 1987:1). A map in "Pioneers Map of J ohnson County" (Young and Dinn n.d.) depicts the Berry Trail crossing the Driftwood River just south of the confluence of the Blue River and Sugar Creek in Section 32, T11N, R5E, crossing into Section 31, then turning north and northwest and paralleling the Mauxferry road (Figures 11 and 12) If so, remnants of this trail may be in Camp Atterbury. Today, Mauxferry road runs through the Camp Atterbury.

From the east, some southern J ohnson County settlers came by way of Whetzel's Trace, a road cut out of the wilderness by J acob Whetzel and others. This trail began around Brookville and ran west toward the bluffs of the White River, placing it north of Camp Atterbury, but it is possible that some Camp Atterbury settlers chose that route (Branigin 1913:34-36). 


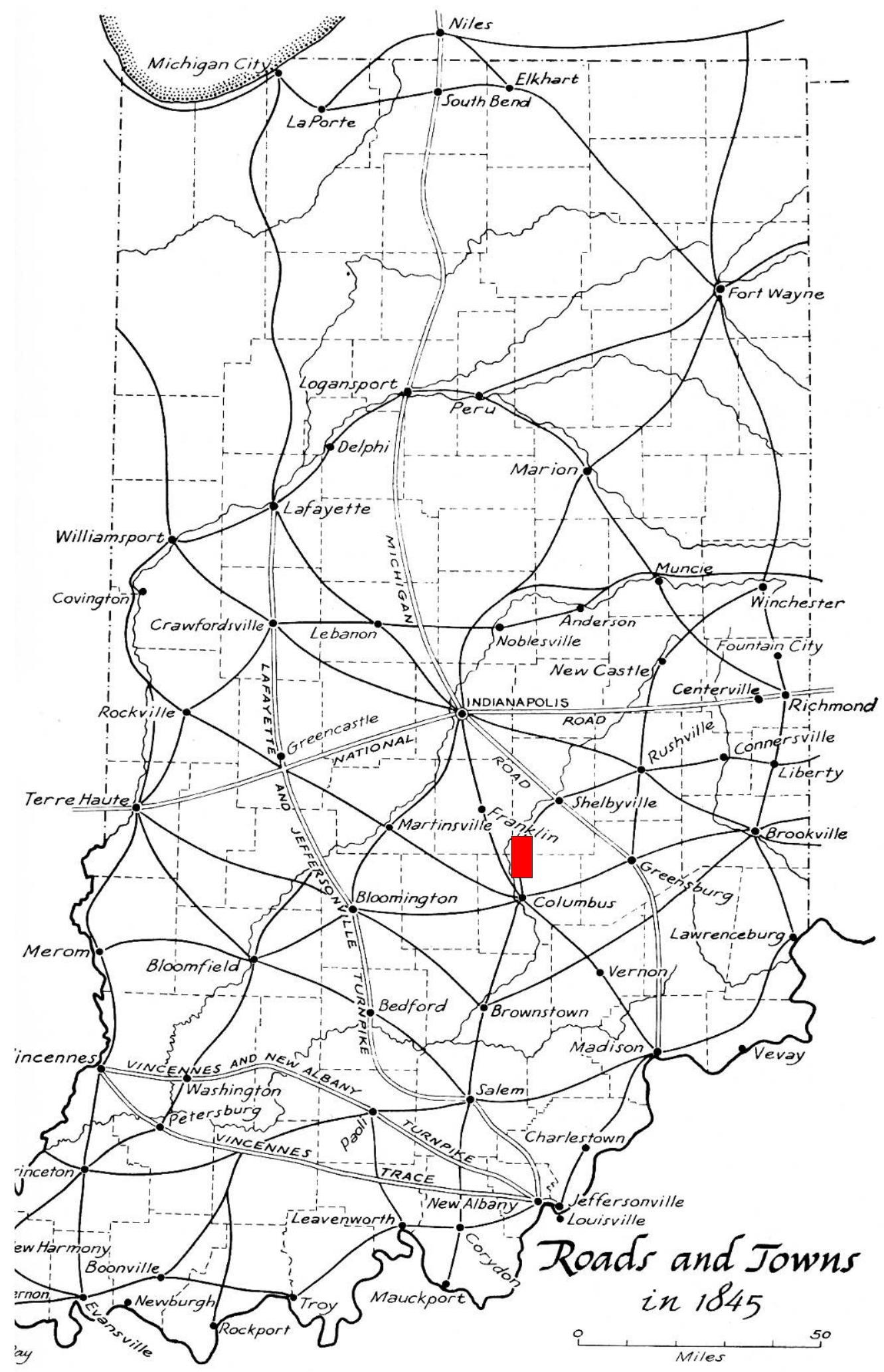

Figure 10. Roads and towns 1845 depicting also earliest trails to Camp Atterbury region. Approximate location of Camp Atterbury in Red (map modified from Hoover and Rodman 1980:69 original by Clark Ray). 


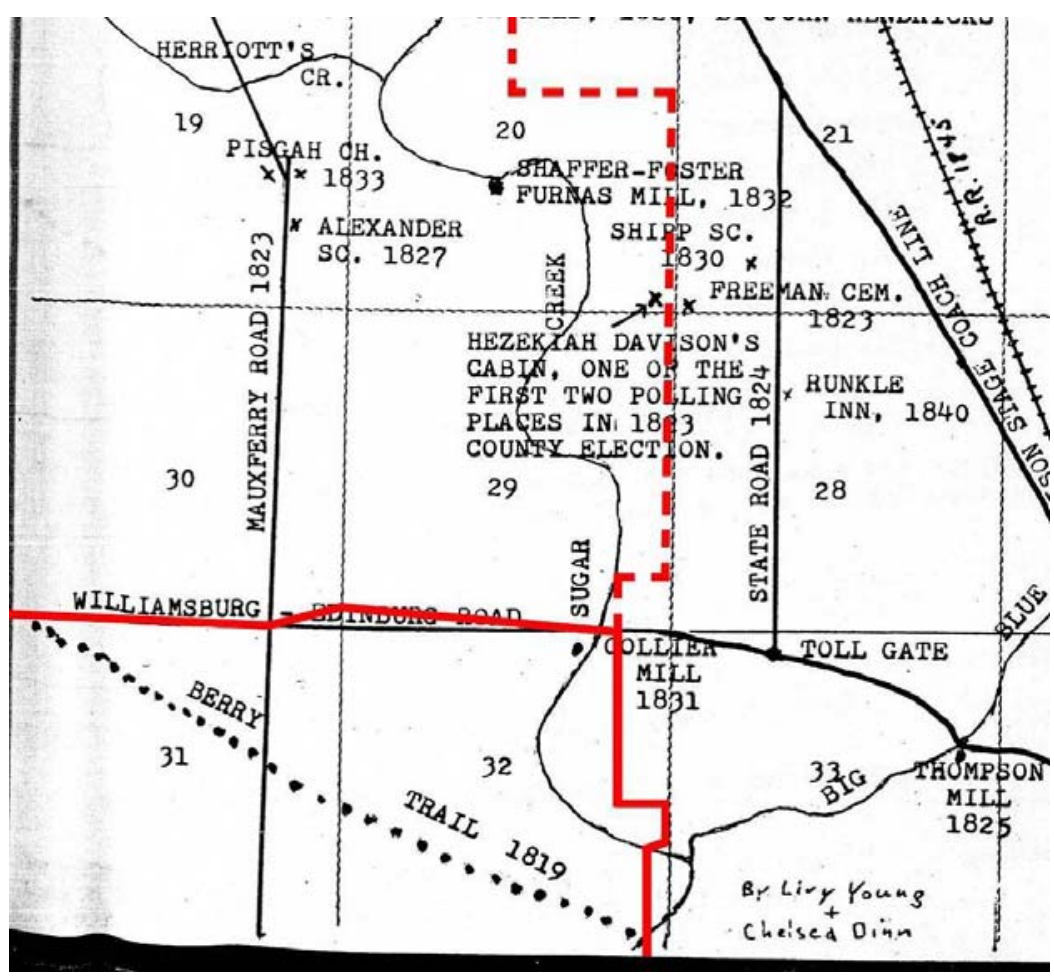

Figure 11. Portion of Young and Dinn Pioneer map of Johnson County, depicting Berry Trail, Mauxferry Road, early settlers and mills in the area. Collier's Mill is within Camp Atterbury (courtesy Young and Dinn n.d.).

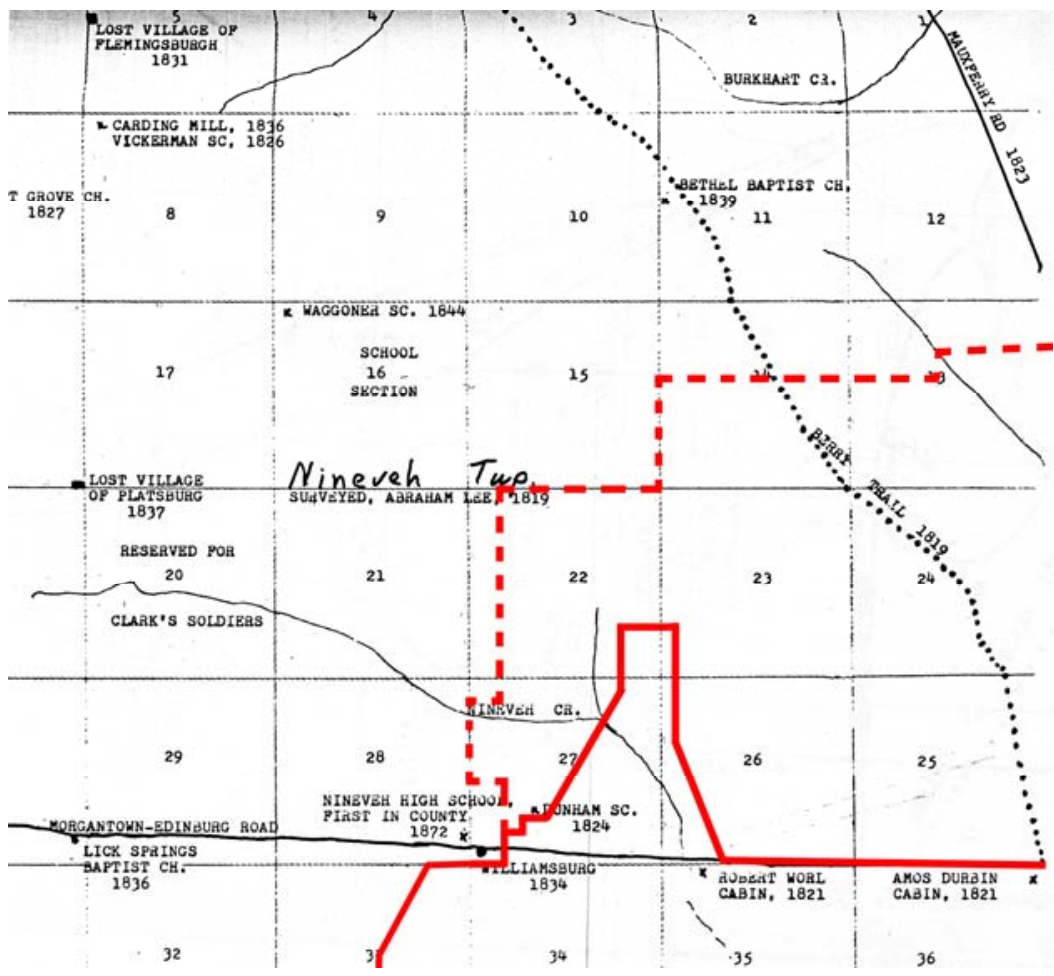

Figure 12. Portion of Young and Dinn Pioneer Map of Johnson County depicting Berry Trail, Mauxferry trail, early settlers and Williamsburg in Nineveh Township (courtesy Young and Dinn n.d.). 


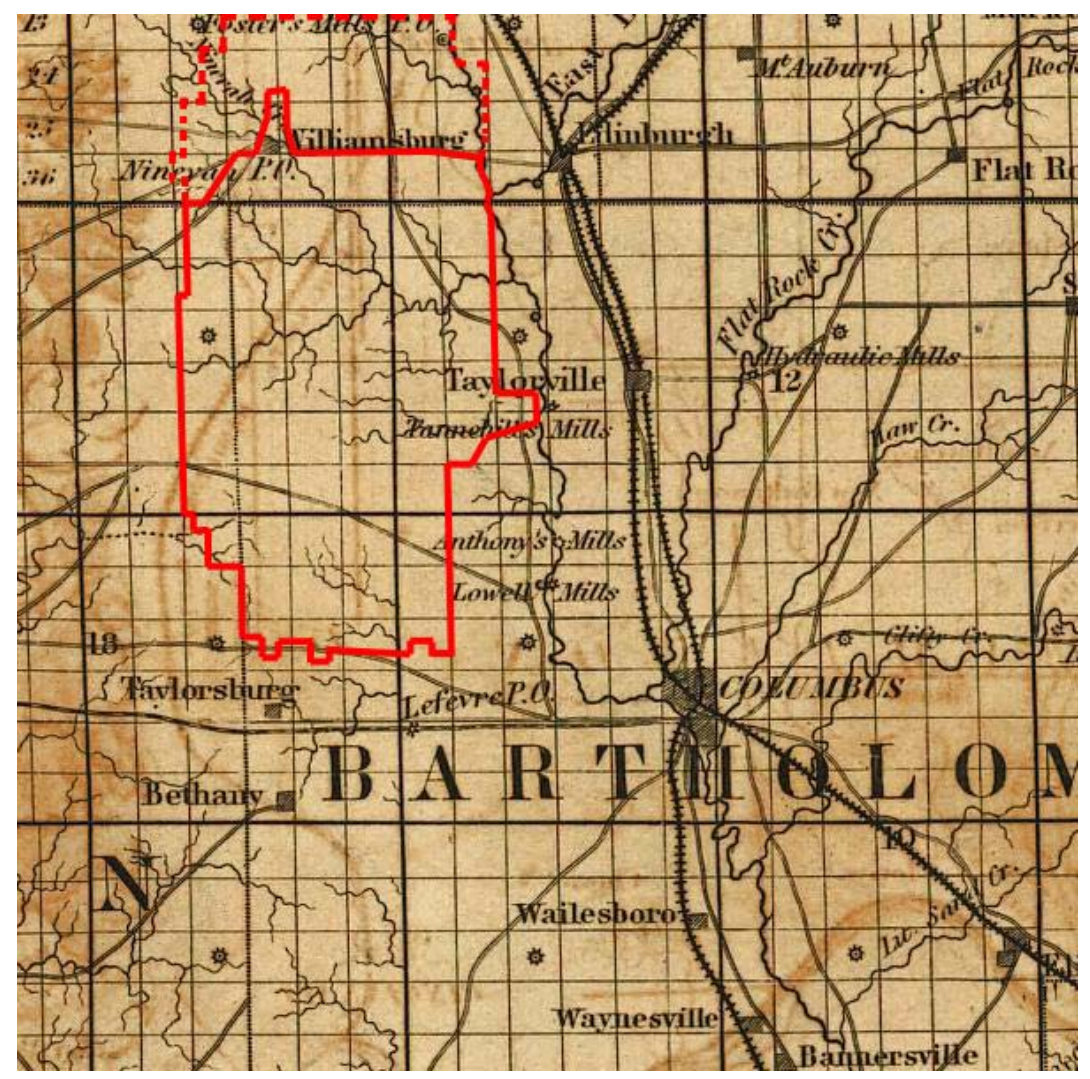

Figure 13. Enlargement of a portion of Colton's 1852 map of Indiana (courtesy Library of Congress Collection of Indiana Historical Maps on-line).

Settlers moving into the Brown County region also used the Mauxferry Road and turned northwest at Salem where they followed a trail to Spark's Ferry then to Vallonia and north into Brown County. Once in Brown County, those settlers who eventually made their way into the northeastern hills around the Taggart settlement followed a trail from Stone Head, to Deadfall Creek, across Henderson (Gnaw Bone) Creek, and then up along the North Fork of Salt Creek to the Hamblen Township (Bailey 1991:15).

Brown County settlers also followed the Mauxferry Road to the Columbus vicinity and then took a trail northwest from Columbus to Martinsville (Figure 10). This trail was unique because it passed through Camp Atterbury, but seems to have totally disappeared by the late $19^{\text {th }}$ century. Colton's map of Indiana dating to 1852 (Figure 11) provides the best and probably most accurate depiction of the main roads at that time. It mapped the Mauxferry Road following the Driftwood River north along the east bank and the earlier trail to Taggart's settlement and Martinsville ended at Taggart's. 
The Madison Road runs north from Madison, IN through J ackson County and crosses the White River at modern day Columbus, IN. Beginning in 1828, the stage ran along this road, taking 4 days to travel 90 miles (Carmony 1998:133). As settlement progressed this trail became the main supply road for Bartholomew and J ohnson Counties (Crump n.d. BaCHS, VF, Transportation). At first, supplies from Madison came on pack horses, but a road quickly developed and supplies came by wagon. Wagons filled with produce such as bacon, lard, dried fruit, deerskins, and maple sugar were shipped to the Ohio River and returned with manufactured goods from the east. Hogs were also driven to Madison. These drives were difficult since "a hog always had his head on the wrong end" (Crump n.d. BaCHS, VF, Transportation). Hogs were the first surplus commodity or "cash crop" that the early farmers sold and despite the difficulty, it was not considered a "particular hardship" to get them to the Ohio River for sale (Banta 1888:351).

Flat boats were used on the Driftwood River to transport heavier products such as lumber, corn, pork, and whiskey. The river was "navigable about twice a year" (Crump n.d.). These boats were 60 to 100 et long by $25 \mathrm{ft}$ wide and were pre-constructed during the fall or winter. In the spring, crews were quickly formed for trips down river to the Ohio River and sometimes to New Orleans via the Mississippi River. Crews were paid from the profits of produce sales and then they returned north by steamboat. As roads improved and trains became more popular, flat boat transportation was abandoned. According to Crump, the last flatboat out of Columbus left in the spring of 1844, the same year the railroad from Madison reached Columbus (Crump n.d. BaCHS). This railroad was completed to Indianapolis in 1847 providing farmers with a national market for their produce (Figure 14).

Once the counties were formed, new roads were built. After 1822 they were partially financed by a Federal Three Per Cent Fund. In 1824, legislation was passed that required males between 21 and 50 to work a minimum of 3 days per year on road construction and maintenance within their county. Landowners were subject to more days up to a maximum of 10 days per year depending on the number of acres owned. A fine of 50 cents a day was assessed on those who did not want to work. In 1831, the number of days was reduced to 2 days per year, but a road tax was added (Carmony 1998:132-132). 


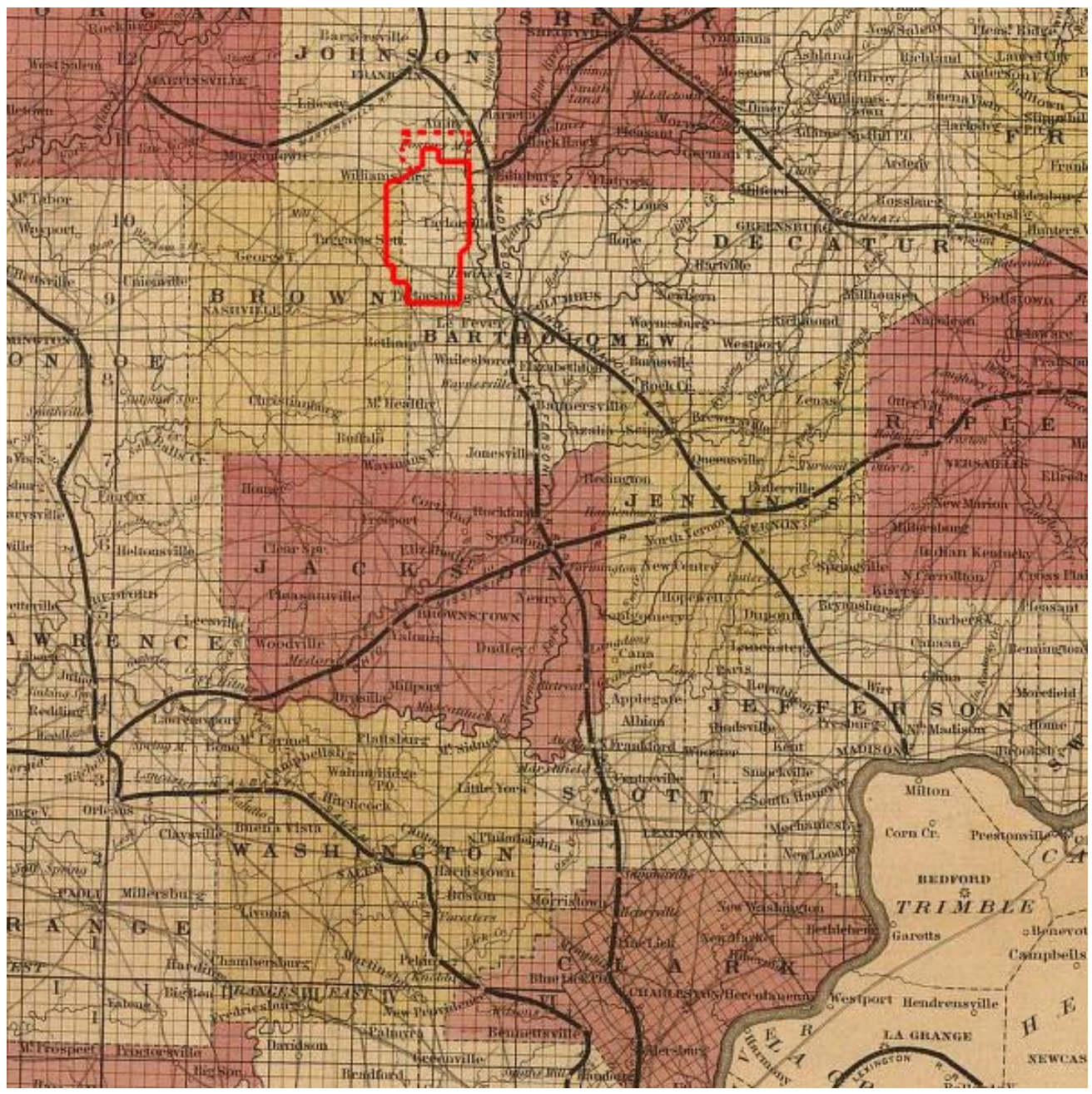

Figure 14. Portion of Johnson's 1858 Railroad map of Indiana. Compare to Fig Road from Columbus to Taggart's and Martinsville complete. Also road from Edinburgh to Williamsburg in place. Red outlines the Camp Atterbury region. (Courtesy Library of Congress collection of Indiana Historical Maps on-line).

The early roads were abysmal. One history of Bartholomew County states that at the time of county organization, "her territory was already traversed by some tolerably well defined roads" (BaCHS 1976:27). However, this does not seem to be the case presented in other sources. The early roads were almost always miserable trails, either muddy or dusty, and often just worn down places in the forests. Trails seemed to splinter randomly, sometimes to avoid obstacles, and the main trail was difficult to follow.

The fall of the year was usually chosen as the time to move, of necessity. The wretched conditions of the Indiana roads as found at almost all other seasons of the year, operated largely to bring this about. From the season of the beginning of the fall rain, on through the winter and spring and till the summer drouths [sic] held the land in their dry embrace, it was next to 
impossible to haul a load from the Ohio River to central Indiana (Banta 1888:330).

Dorthy Bailey, Brown County historian adds:

In the dim forest, trails and traces widened by constant and increasing wagon traffic, never really dried out. In wet weather they were deep in mud and almost impassable. A wagon often sank a foot and a half, and horses or oxen mired to their bellies in the mud. After such an experience drivers turned into the dense woods beside the trail maneuvering between trees, through tangled underbrush and around fallen logs (Bailey 1976:14).

Charles H. Titus wrote a vivid travel journal of his travels from Madison to Indianapolis, IN, in 1843, including the journey through the land that became Camp Atterbury (Clark 1989). Titus was stuck in Columbus due to flooding:

Wednesday morning we prevailed upon a hack driver, who came up from the depot the day before, to try to take us through to Franklin, from which place there was no obstruction till we should arrive at Indianapolis. ... We got started a little after daylight, and arrived at Edinburgh-ten miles-about seven O'clock. Here we were told that we could not possibly proceed. The water in the river was very high, so that all the bottom land on both sides of it was overflown. It was a mile or more across the water at this place. There was a ferry boat, but it was fastened to a tree about midway from either bank, and there was no means of getting it. ... We were now worse off, than if we had staid at Columbus, for there was, her, but on poor, filthy, shabby looking, public house, kept by a widow woman, who had a large family of dirty children (Clark 1989:206-207).

After a breakfast in Edinburgh, Titus and his fellow passengers prevailed upon the stage driver to backtrack to a ferry crossing on the Driftwood, and from there across Camp Atterbury to Williamsburg, IN:

The road back to the ferry was quite good, and we had no difficulty in reaching it. [after the ferry crossing] The road as far as Williamsburgh, was not worse than we had before, but from this place to Franklin, it was horrible, and beyond all description. ... A great part of the road was through the woods, where there was only a cow path, and it was sometimes exceedingly difficult for the coach to pass through (Clark 1989:208). 
Overall, Titus was unimpressed with the landscape for the entire 85 miles from Madison to Indianapolis. "This is the least interesting part of the state of Indiana. ... The land is generally low and swampy, difficult for cultivation and exceedingly unhealthy" (Clark 1989:210).

Ferries, which were established early, were critical to early transportation in Indiana. J ames Thompson in J ohnson County established a ferry in 1831 just south of his mill across the Blue River near Camp Atterbury. He was allowed to charge 6.25 cents for a pedestrian, 12.5 cents for a man on a horse, 25 cents for a two-horse wagon, and 37.5 cents for large wagon pulled by four or more horses (Branigin 1913:517). J ohn Campbell was licensed for another ferry nearby across Sugar Creek a year later. There was another one along the old state road crossing Sugar Creek and one on the Driftwood River (see Titus description). One of the first bridges in J ohnson County was at Thompson's built in 1869 (Branigin 1913:517).

Plank roads were one way to solve the mud problem. The first plank or corduroy road in J ohnson County was constructed in 1850 and stretched from Edinburgh to Nineveh. Plank roads were only $8 \mathrm{ft}$ wide and consisted of square-cut logs laid side by side with boards over top (Branigin 1913:518; Hibbs 2007:29). Today, modern Hospital Road follows the general route of this road. Another alternative to muddy roads was turnpikes. Turnpikes were private roads that travelers paid a toll to the owner to use. They could also be plank or dirt roads, but they were more apt to be better maintained in comparison to public roads. One of the turnpikes ran from Edinburgh to Kansas (BaCHS 1976:28). Turnpike or toll roads were authorized in 1852. One of the best methods to solve the mud problem was to lay gravel. The first gravel roads were constructed in 1865. The Camp Atterbury region was one of the first areas to see gravel roads. The Mauxferry Road from Franklin south to just west of Edinburgh was graveled in 1866 (Branigin 1913:519). Gravel remained the primary road bed through the rest of the $19^{\text {th }}$ century.

The era of the freight wagon ended in 1844 when the railroad made its way to Columbus (Figure 14). The Indiana General Assembly authorized the organization of the Madison, Indianapolis, and La Fayette Railroad on 2 February 1832 (BaCHS 1976:28). When completed it ran from Madison to Columbus and then to Indianapolis. Another railroad company, the Ohio \& Indianapolis Railroad Company was authorized the following day. When it was completed, it ran from J effersonville through Columbus to Indianapolis. The Madison line was completed first. The J effersonville 
Railroad, built north from J effersonville, reached Columbus in 1853. These two railroads then competed (sometimes actual fist fights) with each other having separate parallel lines between Columbus and Edinburgh until 1866. At that time the two companies consolidated as the J effersonville, Madison, and Indianapolis Railroad (BaCHS 1976:29).

\section{The pioneer community}

Population data from the pioneer period indicates that while there was initially a rapid purchase of lands between 1819 and 1825, actual settlement of Camp Atterbury progressed slowly, but steadily afterward. In J ohnson County, Banta states that in 1821 there were 55 families in the whole county, and by 1822 there were still less than 100. "It took ten years to bring it up to 800," stated Banta (Banta 1888:326). Between 1830 and 1840, Bartholomew County population doubled, but only increased another 20 percent by 1850 (Table 1). The formation of Brown County may have had something to do with the slow population growth in Bartholomew County, but that cannot be the only factor leading to the lack of significant increase. In J ohnson County, the population more than doubled between 1830 and 1840, with about a 30 percent increase by 1850. Meanwhile, Brown County population doubled between 1840 and 1850.

The 1860 census is the first record of settlement density in the CAJ MTC. It indicates that Nineveh and Union Townships, Bartholomew County (the principal townships that constitute Camp Atterbury today) accounted for only 1679 people or 9 percent of Bartholomew County's population (Table 2). In the J ohnson County region, Nineveh and Blue River Township's population was only 13 percent of J ohnson County's population. Hamblen Township accounted for 25 percent of Brown County's population, but Camp Atterbury only has a sliver of land in that township.

Table 1. Population of Bartholomew, Johnson, and Brown Counties, $1830-1850$.

\begin{tabular}{|l|l|l|l|l|l|l|}
\hline \multirow{3}{*}{ County } & \multicolumn{3}{|l|}{1830 Census } & \multicolumn{2}{l|}{1840 Census } & \multicolumn{2}{l|}{1850 Census } \\
\cline { 2 - 8 } & White & Black & White & Black & White & Black \\
\hline Bartholomew & 5,476 & - & 10,008 & 34 & 12,346 & 82 \\
\hline Johnson & 4,019 & - & 9,332 & 20 & 12,086 & 15 \\
\hline Brown & - & - & 2,341 & 23 & 4,827 & 19 \\
\hline Totals & 9,495 & & 21,758 & 77 & 29,375 & 116 \\
\hline
\end{tabular}


Table 2. Population of Nineveh and Union Townships, Bartholomew County, Nineveh and Blue River, Johnson County, and Hamblen Township, Brown County, 1860 and 1870. Parentheses indicates Black population.

\begin{tabular}{|l|l|c|c|}
\hline County & Township & 1860 Census Total & 1870 Census Total \\
\hline Bartholomew & & $17,865(7)$ & $21,133(11)$ \\
\hline Bartholomew & Nineveh & $879(0)$ & $767(0)$ \\
\hline Bartholomew & Union & $800(0)$ & $1,008(0)$ \\
\hline Johnson & & $14,854(19)$ & $18,366(115)$ \\
\hline Johnson & Nineveh & $1,761(0)$ & $1,650(0)$ \\
\hline Johnson & Blue River & $295(0)$ & $2,573(25)$ \\
\hline Brown & & $6,507(0)$ & $8,681(1)$ \\
\hline Brown & Hamblen & 1,627 & 2,011 \\
\hline
\end{tabular}

By 1870, the tri-county regional population reached its maximum density until the creation of Camp Atterbury. An increase of 3268 in Bartholomew County (18 percent increase) and 3512 (23 percent increase) in J ohnson County indicates steady progress, but also may reflect some out-migration of veterans after the Civil War.

Surprisingly few people lived in Blue River Township, J ohnson Countyonly 295 people in 1860 . One explanation may be that the rivers were subject to flooding, making a lot of the land unusable until it was better drained. By 1870 the population had increased substantially to 2573. This may have been due to the village of Edinburgh's location along the main highway and railroad, which made the town a central economic node in the immediate area. Another interesting phenomenon is that although Hamblen Township, Brown County had poor soils, in the 1860s and 1870s it had greater population than the other townships that were later incorporated into Camp Atterbury. Only J ohnson County's Blue River Township had a greater population in 1870 .

The census shows that the largest ethnic population in the tri-county area was decidedly Euro-American. From 1830 to 1870, the African American population never exceeded 40 residents in Bartholomew, J ohnson, or Brown Counties. The townships that later composed Camp Atterbury had fewer with only 25 African Americans in Blue River Township in 1870, who likely lived in Edinburgh.

\section{Pioneer Agriculture}

The number of squatters in the Camp Atterbury area is impossible to calculate. It is doubtful that more than a family or two arrived prior to the 
New Purchase, but after that, the flow of settlers began. The first wave of settlers had to be self-sufficient. Arriving on their land, they camped in the woods while they built cabins. Arriving in mid summer, usually the first act was to clear some land and get started on a corn crop, even before the cabin was built. "It was so common in the pioneer times, this moving into unfinished cabins, that it seldom or never caused comment. It may be safely assumed that during the first 10 years after the first white man moved to the [Johnson] county, more than half of the people who came to find homes, lived for a time in unfinished cabins. Quilts and blankets hung over the cabin doors and windows, gave protection against the wind and weather for weeks, and in some instances, for months, to a large per cent of the people who came during those first ten years" (Banta 1888:328329). As the population rose, later settlers could hire laborers to assist in getting them homesteaded. "A cabin of two rooms, finished after the fashion of the times, usually cost about \$50" (Banta 1888:326).

Clearing the land for crops, draining the swamps, cutting the trees, damming the rivers and creeks for mill races, burning the underbrush (again), and clearing away the roads had a profound impact on the landscape, including changing the flora and fauna in Camp Atterbury. Besides reducing the deer population and eventually driving panthers, bears, wildcat, wolves, and other mammals to near extinction, new species like cattle, sheep, and new species of dogs were introduced. Hogs were introduced to the forests, which provided them with an abundance of meat. Turned loose to graze, hogs took over the pioneer forests as early as 1824 (Banta 1888:333), and in turn provided the early settlers with a ready source of meat. Being difficult to brand once they were turned loose, hog thieves also became a common nuisance to the farmer.

As previously noted, crops were in danger from raccoons, wild turkeys, and other birds. Yet grey squirrels were one of the most noisome pests for the early settler. Historian D. D. Banta describes in great detail the struggle between man and squirrel:

But the depredation of the grey squirrels was greater than that from all other causes combined. ... They prowled around the fields and found hiding places in the dead tree left standing herein. As soon as the seed corn was covered they began their work of destruction, and kept it up till the grain was absorbed by the growing plant. With what certainty a squirrel will follow the row and dig in the corn-hills only, till he found the grain. ... Thence on till earing time the rodents could do no harm, but no sooner were the grains found on the cob than the spring marauders, ac- 
companied by a full grown progeny, returned, and between themselves, the birds and raccoons, the little field stood a sorry chance. Some years were worse than others, but all were bad. The years 1824, 1834, and 1836, were specially bad ones. ... The children were sent to the fields armed with every conceivable device for making noise. They rattled "horse fiddles" and bells, and beat on fence rails and hollow stumps and trees, with clubs. ... [One early settler on the Blue River, describes her childhood] - he would waken her and her sisters, and they would immediately go to their respective stations in the field and begin the noisy demonstrations of the day. During the heat of the day the squirrels lay concealed in the woods, and they rested from their labors, but as the afternoon sun descended, the squirrels returned and they resumed their noisy demonstrations in the field (Banta 1888:340-341).

Farmers set traps and also shot the squirrels, sometimes working all morning in the field and spending the entire afternoon shooting squirrels.

Pioneer period census data does not allow for a detailed analysis of the Camp Atterbury region. However, the general data does provide clues to the tri-county regions' agricultural life. Statistics clearly reflect a thriving rural farming community developing steadily from initial settlement to the post war period. In 1850, there were 1249 farms in Bartholomew County, 535 in Brown County, and 1153 in J ohnson County. By 1860, Bartholomew had grown to 1566 farms, Brown to 736, and J ohnson County to 1837. At that time, 80 percent of Bartholomew County (214,954 acres), 55 percent of Brown County (111,182 acres) and 79 percent of J ohnson County (163,084 acres) was classified as agricultural. Furthermore, these farms were overwhelmingly small family farms (Table 3). The vast majority (70 percent) of farms in the tri-county region were between 20 to 100 acres. Some 22 percent were between 100 and 500, but there were only nine farms over 500 acres.

Table 3. Farm sizes for Bartholomew, Brown and Johnson Counties, IN in 1860.

\begin{tabular}{|l|c|c|c|c|c|c|c|c|}
\hline County & $\begin{array}{c}\text { Under } \\
10\end{array}$ & $\begin{array}{c}10 \text { to } \\
19\end{array}$ & $\begin{array}{c}20 \text { to } \\
49\end{array}$ & $\begin{array}{c}50 \text { to } \\
99\end{array}$ & $\begin{array}{c}100 \text { to } \\
500\end{array}$ & $\begin{array}{c}500 \text { to } \\
999\end{array}$ & $\begin{array}{c}\text { Over } \\
1000\end{array}$ & Totals \\
\hline Bartholomew & 10 & 98 & 602 & 521 & 328 & 7 & 0 & 1,566 \\
\hline Brown & 27 & 94 & 357 & 188 & 70 & 0 & 0 & 736 \\
\hline Johnson & 11 & 54 & 510 & 733 & 527 & 2 & 0 & 1,837 \\
\hline
\end{tabular}


Agricultural statistics indicate that the Camp Atterbury region consisted of small diversified farms, with the main cash crop being corn and the main livestock being hogs (Tables 4, 5, 6, 7, and 8). Like the southern states, swine were the dominate meat source in the region. Cattle were important, but the number of hogs far out numbered head of cattle (data are missing for the 1860s and 1870s). For some unknown reason, swine production was considerably reduced by the 1870s. Perhaps fencing laws were the reason. In 1851, Indiana passed a law requiring farmers to fence in their animals. For a long time this law was ignored, but when it started being enforced, it caused much anger among farmers in the hills of Bartholomew and Brown Counties (Nicholson1992:68).

Table 4. Selected livestock production for tri-county region 1840 through 1870.

\begin{tabular}{|l|c|c|c|c|}
\hline County & Horses/Mules & \multicolumn{1}{l|}{ Cattle } & \multicolumn{1}{l|}{ Sheep } & \multicolumn{1}{l|}{ Swine } \\
\hline Bartholomew 1840 & 2,188 & 7,324 & 7,061 & 25,244 \\
\hline Bartholomew 1850 & 4,314 & 9,336 & 14,531 & 44,869 \\
\hline Bartholomew 1860 & 6,376 & - & 10,666 & 50,420 \\
\hline Bartholomew 1870 & 7,237 & - & 15,838 & 38,546 \\
\hline Johnson 1840 & 2,389 & 7,283 & 7,087 & 14,318 \\
\hline Johnson 1850 & 4,605 & 8,848 & 19,335 & 36,055 \\
\hline Johnson 1860 & 6,833 & - & 11,775 & 45,472 \\
\hline Johnson 1870 & 7,106 & - & 13,775 & 30,006 \\
\hline Brown 1840 & 652 & 2,261 & 2,635 & 6,927 \\
\hline Brown 1850 & 1,347 & 2,755 & 5,260 & 9,977 \\
\hline Brown 1860 & 1,687 & - & 5,669 & 146,009 \\
\hline Brown 1870 & 2,103 & - & 8,404 & 7,100 \\
\hline
\end{tabular}

Table 5. Selected crop production for tri-county area in 1840 . Wheat, rye-oats, corn, potatoes in bushels, wool and tobacco in pounds, hay in tons.

\begin{tabular}{|l|c|r|l|l|l|l|l|}
\hline County 1840 & Wheat & Rye, Oats & Corn & Potatoes & Wool & Hay & Tobacco \\
\hline Bartholomew & 37,149 & 55,404 & 470,630 & 10,861 & 12,094 & 1,212 & 1,454 \\
\hline Brown & 3,328 & 9,411 & 66,578 & 3,539 & 2,991 & 71 & 3,562 \\
\hline Johnson & 56,691 & 83,700 & 497,028 & 14,121 & 20,343 & 2,088 & 49,484 \\
\hline
\end{tabular}

Table 6. Selected crop production for tri-county area in 1850 . Wheat, rye-oats, corn, potatoes in bushels, wool, tobacco, butter-cheese in pounds, hay in tons.

\begin{tabular}{|l|l|l|l|r|r|r|r|l|}
\hline County 1850 & Wheat & Rye, Oats & Corn & Potatoes & Wool & $\begin{array}{l}\text { Hay, } \\
\text { tons }\end{array}$ & Tobacco & $\begin{array}{l}\text { Butter/ } \\
\text { Cheese }\end{array}$ \\
\hline Bartholomew & 102,531 & 60,038 & $1,173,902$ & 20,722 & 32,014 & 3,558 & 4,800 & 181,937 \\
\hline Brown & 14,154 & 19,019 & 179,304 & 7,514 & 10,029 & 642 & 9,504 & 49,343 \\
\hline Johnson & 99,038 & 34,802 & 993,375 & 15,496 & 41,602 & 3,082 & 11,538 & 140,668 \\
\hline
\end{tabular}


Table 7. Selected crop production for tri-county area in 1860 . Wheat, rye-oats, corn, potatoes in bushels, wool, tobacco, butter-cheese in pounds, hay in tons.

\begin{tabular}{|l|c|c|c|c|c|l|l|l|}
\hline County 1860 & Wheat & Rye, Oats & Corn & Potatoes & Wool & $\begin{array}{l}\text { Hay, } \\
\text { tons }\end{array}$ & Tobacco & $\begin{array}{l}\text { Butter/ } \\
\text { Cheese }\end{array}$ \\
\hline Bartholomew & 3,099 & 108,873 & $1,412,285$ & 36,285 & 26,494 & 5,568 & 17,136 & 325,194 \\
\hline Brown & 56,410 & 34,037 & 220,496 & 16,683 & 10,647 & 1,534 & 170,715 & 57,532 \\
\hline Johnson & 262,383 & 68,094 & $1,331,522$ & 21,517 & 33,511 & 5,177 & 32,108 & 265,724 \\
\hline
\end{tabular}

Table 8. Selected crop production for tri-county area in 1870. Wheat, rye-oats, corn, potatoes in bushels, wool, tobacco, butter-cheese in pounds, hay in tons.

\begin{tabular}{|l|l|l|l|l|l|l|l|l|}
\hline County 1870 & Wheat & Rye, Oats & Corn & Potatoes & Wool & $\begin{array}{l}\text { Hay, } \\
\text { tons }\end{array}$ & Tobacco & $\begin{array}{l}\text { Butter/ } \\
\text { Cheese }\end{array}$ \\
\hline Bartholomew & 491,424 & 113,568 & $1,529,675$ & 67,352 & 0 & 9,370 & 0 & 221,080 \\
\hline Brown & 83,056 & 63,634 & 197,734 & 17,770 & 0 & 2,348 & 0 & 67,754 \\
\hline Johnson & 544,917 & 21,928 & $1,240,220$ & 50,392 & 45,363 & 6,376 & 0 & 300,915 \\
\hline
\end{tabular}

The tri-county farmers grew a wide variety of crops, including wheat, rye and oats, corn, hay, tobacco, and potatoes (Tables 5, 6, 7, and 8). Wool and Cheese products were also important, and there were a variety of crops produced in small quantities like barley, buckwheat, hops, peas, beans, hemp, flax, wine, and beeswax.

These statistics do not necessarily reflect what was happening in Camp Atterbury, but reflect general trends in the tri-county area. The statistics indicate that corn was the primary cash crop and that all the counties increased corn production steadily through the mid $19^{\text {th }}$ century, with a slight drop in production in 1870. Likewise, the production of wheat, potatoes, rye, and oats increased throughout this period, with the exception of rye and oats in J ohnson County, and an unexplained dramatic drop in wheat in Bartholomew County in 1860. Overall, wheat production increased significantly throughout this period as a result of a world-wide demand (Nicholson1992:64-65). Interestingly, wheat had the greatest market potential, but the first settlers found the soils in Indiana actually too fertile for wheat. It took four to 15 crops of corn before the soils were depleted enough to grow a good crop of wheat (Salstrom 2007:43). In 1870, tobacco and wool crops disappeared except for J ohnson County wool production. Overall, these statistics reflect a rural farming community with a reliance on corn and swine in a thriving market economy.

\section{Hamlets, villages, and towns}

Throughout its settlement history, the Camp Atterbury region was a distinctively rural farming region. Within what became Camp Atterbury, there were no real settlement clusters that could be described as towns. 
The closest town was Edinburgh, just east of the modern cantonment. The hamlet of Taylorsville was to the southeast. For those who settled in the southern portion of Camp Atterbury, Columbus was only about 4 miles east and was the largest town in Bartholomew County.

On 15 February 1855, William A. Ergenbright laid out 31 lots in Section 12, T10N, R4E of Bartholomew County's Nineveh Township, which became known as Kansas (BaCHS VF: Early Communities). Kansas is an important archaeological site today (Figure 15). Albertus Ergenbright established one of the first general stores in the little hamlet. It had a post office from 21 May 1856 to 9 May 1863 (Baker 1995:182).

Settlers in Camp Atterbury's northern portion used Edinburgh for supplies and services. Edinburgh was platted in 1822 (Banta 1888:528; Otto 1987:7). It was originally platted for 32 lots, only one lot more than Kansas (Otto 1987:9). However, historian D. D. Banta says that a town plat in 1825 depicts 63 lots on 27 blocks (Banta 1888:528). On Driftwood River, Edinburgh was ideally located for the earliest settlers. William Hensley made a quick fortune by opening a store in 1822 as agent for the Booth and Newby Store of Salem, IN. Isaac Collier opened a blacksmith shop and J ohn Adams added a wheel wright shop (Otto 1987:10-11).

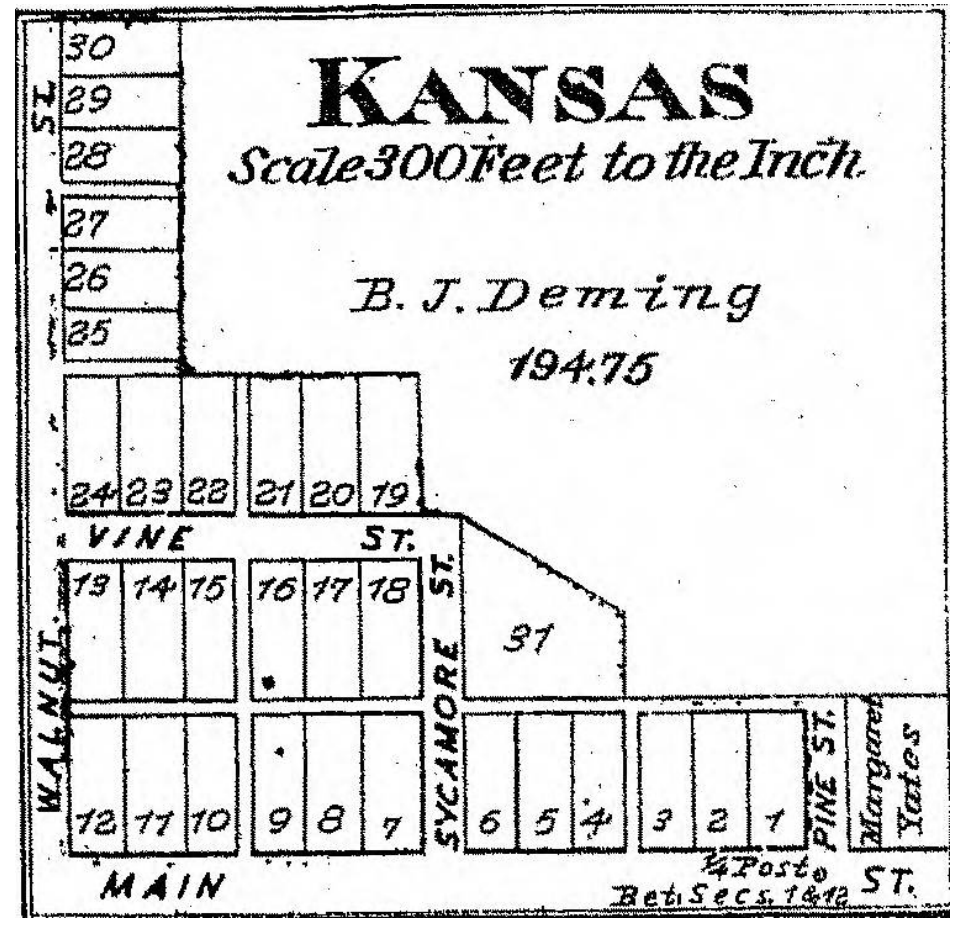

Figure 15. Plat of hamlet of Kansas, in Bartholomew County, IN, within the CAJMTC. (courtesy Atlas of Bartholomew County, 1879.). 
By the fall of 1822, there were four families living in Edinburgh (Banta 1888:529). By 1823 there was a post office and a cabinet shop. The post master delivered the mail on Sundays to families who came to Edinburgh to attend church. In 1845, there were 250 inhabitants (Banta 1888:531) and Edinburgh was on its way to becoming a regional market center for southern J ohnson County. It remained so throughout the $19^{\text {th }}$ Century.

Another small hamlet serving those in the northern Camp Atterbury area was Williamsburg (Later Nineveh) (Figure 16). Williamsburg was one of the earliest villages in J ohnson County. Hunter J oab Woodruff was one of the first to arrive in the area around 1822 (Banta 1888:555). Woodruff obtained 370 deer and bear skins and took them to Madison where he purchased dry-goods with his profits. He returned to the area and opened a store to serve the local families (Banta 1888:556).

Woodruff also established a post office on 26 November 1832 called Woodruff's (Baker 1995:243). On 22 February 1839 the post office name was changed to Ninevah (now Nineveh) (Baker 1995:243). Daniel Mussulman was the first to actually settle on the present site of Williamsburg and he also opened a store. The two stores became a central node in the community for other economic and social needs. Dr. William J ohnson also opened a practice in the area. The village was platted in May 1834 as Williamsburg (Baker 1995:243). One of the first industries was a distillery established around the time the village was platted; however, it was controversial for the local residents (Bergen 1984:256).

Charles Titus was not impressed with Williamsburg or its inhabitants in 1843. Titus was on his way to Indianapolis from Columbus and was detoured to Williamsburg. He wrote:

At Williamsburg, we had a fair sample of a backwoods village. A cluster of ill arranged houses, built principally of logs, and in every conceivable form and shape. One store with a few old rusty goods and a "beggarly account of empty boxes"; a black smith's shop, which consisted of a few logs thrown up, a small stone chimney, a small bellows, and a small man to blow them; one tavern, built also of logs, presenting a most filthy and unforbidding aspect (Clark 1989:208). 


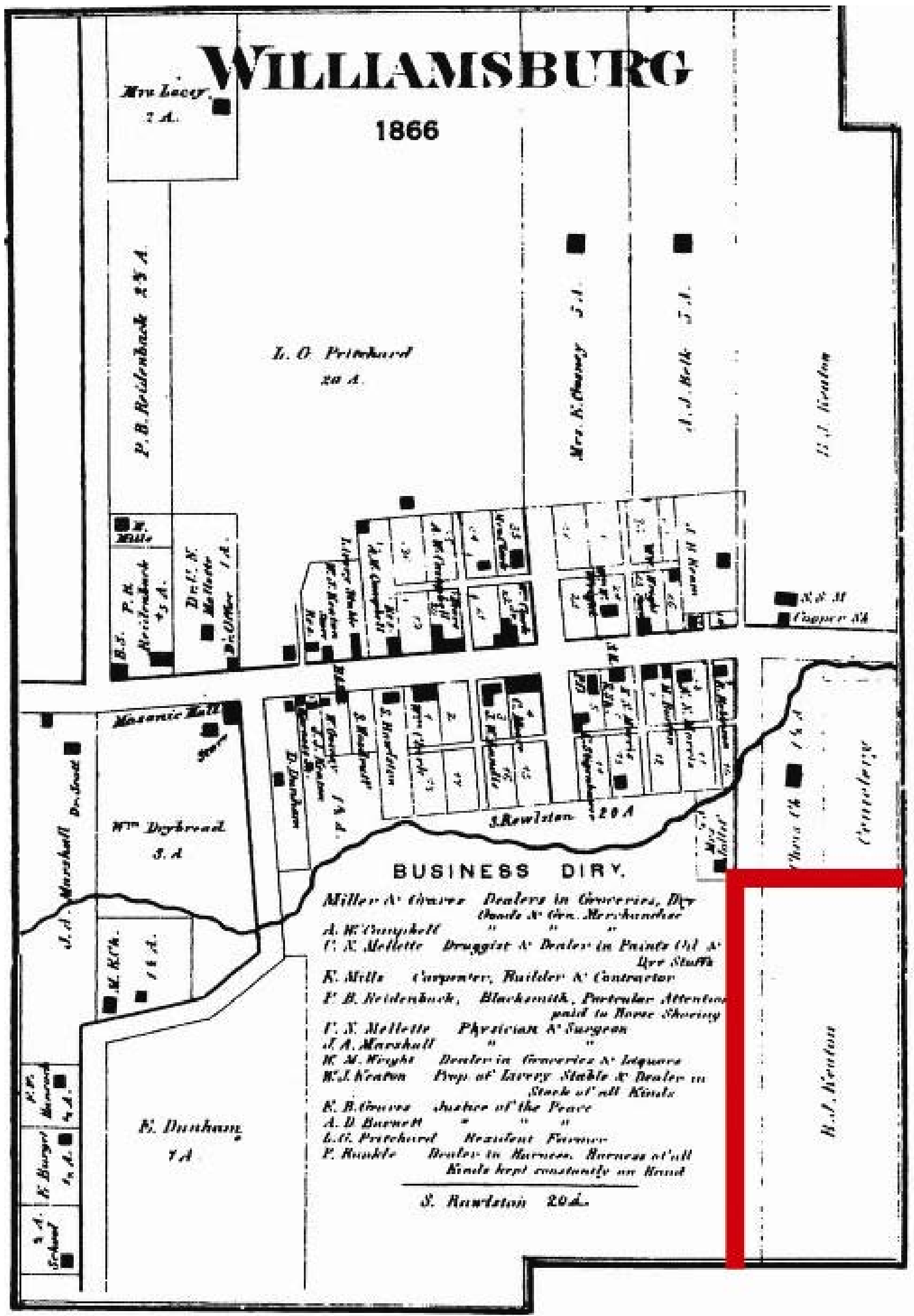

Figure 16. 1866 plat of Williamsburg, Nineveh P.O. (courtesy, Atlas of Johnson County, IN, 1984). 
Not content to disparage the town, he also wrote the following about the residents:

Their countenances bespoke of ignorance, superstition and general accompaniment "brass." Among them was found the blustering politician, the know-everything physician, the profound metaphysician and the astute theologian. Their dress was of all colors and fashions. Take them, all in all, they presented a rather ludicrous appearance. (Clark 1989:208).

Despite Titus's disparagement of Williamsburg, the town grew well and rivaled Edinburgh until 1845 when the railroad arrived at Edinburgh. Residents nearer to Brown County had few places to go for supplies and most had to turn to Bartholomew or J ohnson County villages. There was a small hamlet just outside of Camp Atterbury called Mt. Moriah, near the Taggart settlement. A post office was established there in 1850 (Baker 1976:987).

Finally, there was Taylorsville, between Edinburgh and Columbus, a small village on the rail line a few miles east of Camp Atterbury. The town began when the railroad came through and was platted in 1849. The first business was a grain warehouse, owned by a Samuel H. Steinberger. The village became locally important as a distribution point for corn and livestock to national markets. The Tanny Hill Mill along the Driftwood River was a mile west of the town. The village was originally called Herod, but like a lot of little villages at the time, the name was changed when the post office was established (Columbus Republic 1895). After serving as a prominent citizen in Taylorsville, Samuel Steinberger moved to Kansas in 1887 (BaCHS 1976:172).

\section{Churches and schools}

The record of settlement in central Indiana indicates that after 1818, settlers arrived at a steady pace, and by the end of the 1830s, most of the land had been claimed, if not settled. Many of the land claims, especially where there was desirable farmland, occurred between 1820 and 1825. As settlers arrived they wasted no time developing a typical Midwestern rural community. Such a community first needed a governmental infrastructure, which in this case was already in place with the formation of the county. Second, they needed a social infrastructure in the form of churches, schools, and other social organizations. 
Characteristically of this period in American history, "Among the pioneers of Bartholomew County almost every Christian denomination was represented. The settler's cabin was scarcely completed before the itinerant or missionary was there with Bible and hymn book gathering the widely separated families together for worship" (BaCHS 1976:113). Certainly circuit riders were passing through the area by 1821 and continued throughout the pioneer period, but congregations were also quickly organized, meeting at first in private homes. Beginning in the 1830s church buildings were built and by the 1850s were well distributed across the region (Figures 17, 18). Historian D. D. Banta noted, for example that, the Baptists organized at Daniel Mussulman's home in Nineveh Township (J ohnson County) (Banta 1888:359). These early churches were often cooperative efforts, where different denominations would join together to build one church to serve more than one denomination (Goetz n.d.). The buildings were in fact community centers and were used for a multitude of social gatherings.

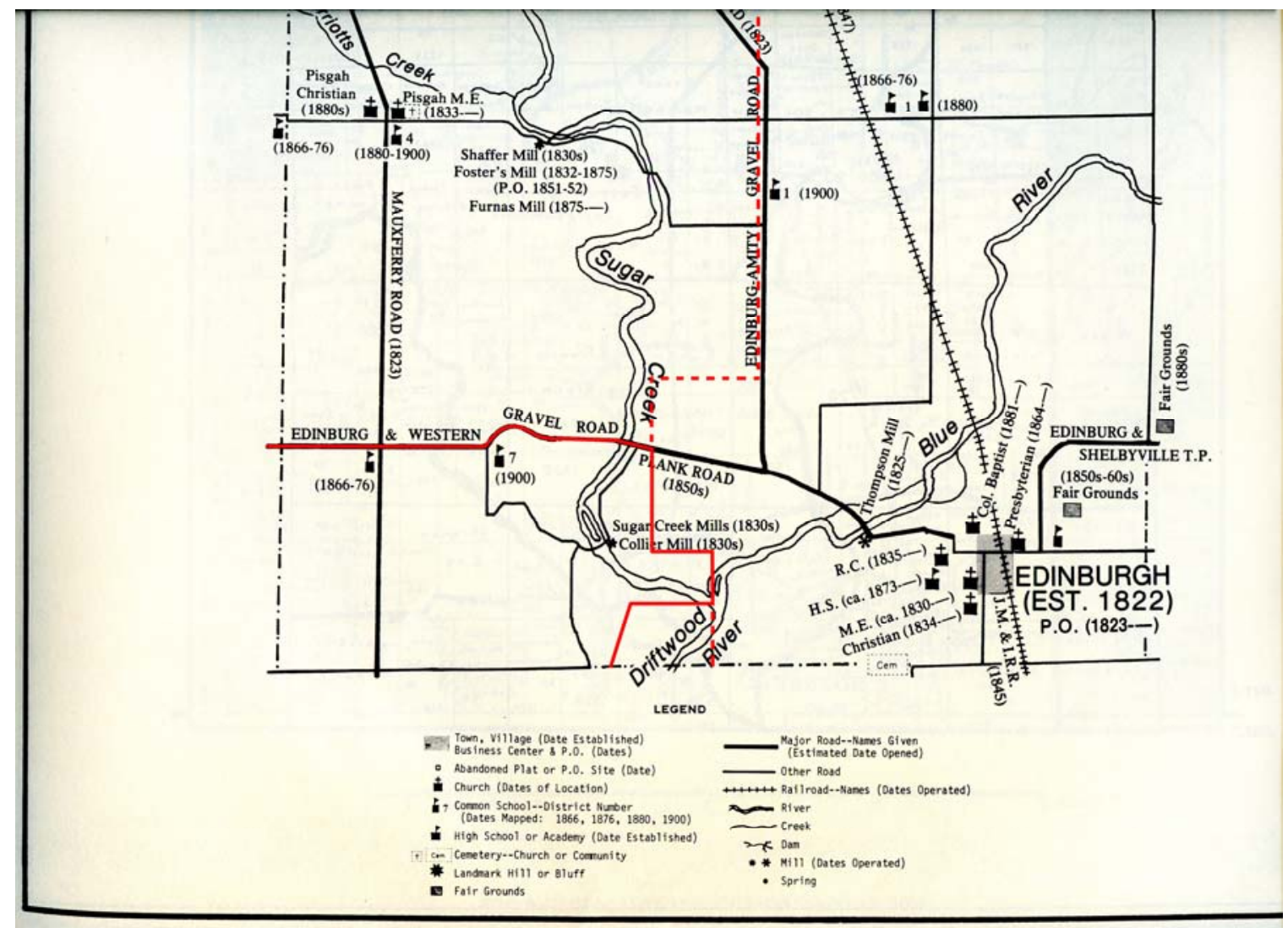

Figure 17. Churches, schools, and mills east of Edinburgh in the mid-19th century (courtesy Atlas of Johnson County, 1984). 


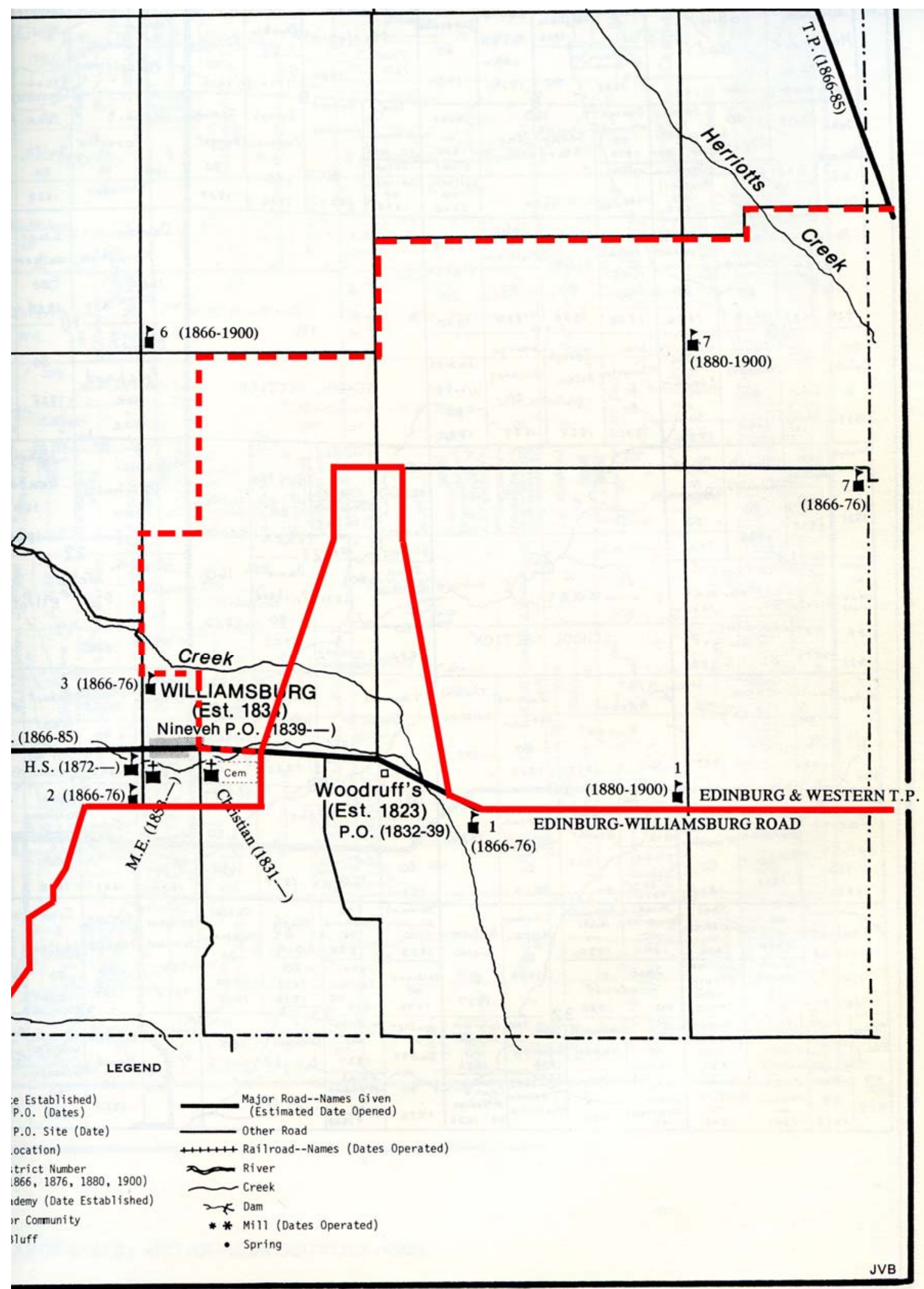

Figure 18. Churches and schools in the Williamsburg community in the mid-19th century (courtesy Atlas of Johnson County, 1984. 
There was a meeting house as early as 1822 in the Hawpatch region, only a year after the county was established (BaCHS 1976:93). A "chapel" for the Methodist Episcopal (M.E) was organized in 1821 in Columbus Township (BaCHS 1976:98). Closer to Camp Atterbury, there was an M.E. congregation in Taylorsville by 1833, and they built a church in 1850. The Bethel M.E. church was constructed around 1853 in Union Township, 21/2 miles west of Taylorsville (BaCHS 1976:98). Taylorsville also had a New Light Christians house built in the 1860s (BaCHS 1976:108).

Within the Nineveh Township, Bartholomew County section of Camp Atterbury, the Methodists organized a church around the late 1830s (BaCHS 1976:100). Catholics built a church in Union Township in 1855 called St. John's at Mt. Erin (BaCHS 1976:106).

In J ohnson County the Blue River Baptists organized in 1823 at the forks of the Blue and Sugar Creek, just outside of Camp Atterbury (Flatrock Association minutes, 1823-1899, J CHS Vertical Files). Another Baptist Church, the Nineveh Baptists, was built around 1824 near Williamsburg. Also in Williamsburg the Nineveh Church of Christ organized at the school house in 1832 and constructed its own building in 1840 .

Historians note that schools developed slowly in pioneer Indiana, and certainly prior to the Civil War most children were either home schooled or remained illiterate. Throughout the $19^{\text {th }}$ century most schools remained one room school houses. A "general system of education" was even a part of the Indiana constitution in 1816 (Carmony 1998:363) so while it took some time to establish a public system, children's education was a pioneer goal in the new counties.

In the second quarter of the $19^{\text {th }}$ century private schools were established within the Camp Atterbury region. In Nineveh Township, Bartholomew County, there was a school on J ohn Drybread's farm by around 1832, taught by J ohn Wilson (BaCHS 1976:134). Thomas Lowry taught in the township prior to 1838. J ohn Ball was teaching near Kansas by 1840 . J acob Slack had a subscription school by 1841. Union Township's first school was established in 1840 (BaCHS 1976:136-137).

On the north end of Camp Atterbury, an Ohio man named Aaron Dunham arrived at Williamsburg in 1824 and announced he was a school teacher. The settlement signed a contract with him to teach for 3 months at $\$ 2.40$ per student, and he taught in the home of William Strain (Hibbs 2007:24). 
Schools sprang up after that, and in 1852, Williamsburg established an academy, which at the time was the equivalent of a high school (Hibbs 2007:25). By 1869, there were six schools within Nineveh Township, Bartholomew County: (1) District School No. 1 or Records School (east of Kansas, Section 6), (2) School No. 2 or Stucker School (Section 19), (3) School No. 3, Drybread (Section 2, west of Kansas), (4) School No. 4, (Section 14), (5) School No. 5, Nevill (Section 15, near Brown County Line), and (6) School No. 6, Hog Bottom or Renner School (Section 16). The Hog Bottom School was replaced in 1887 (Marshall and Prather 2003:213).

Mary Ann McCray provides a description of a one room school built around 1867 along the Ohio Ridge in Union Township, that was likely typical of the period:

... about $30 \mathrm{ft}$ by $40 \mathrm{ft}-9 \mathrm{ft}$ high 3 windows on the east side, 3 windows on the west large black board across north end 1 door in south end. 1 box wood stove, 12 or 14 double seats 6 or 8 single seats 1 large map holder 1 painted bench-to set on in class 1 large dictionary 1 hand brass bell \& three corner cupboards, one in south corner used for dinner buckets in northwest corner for teachers use cistern well for water north side of school (BaCHS Vertical Files, "School” n.d.).

\section{Industries}

The early pioneers were all subsistence farmers, but soon the rich soils in the northern part of Camp Atterbury provided a surplus crop that could be used for barter and eventually be sold for cash to build a more prosperous farm. Subsistence farmers needed little, but in order to grow to cash crops they needed at least a mill, blacksmith, and a store within a reasonable distance. Horse driven mills filled the void in some cases. "A history of Bartholomew County states that the earliest settlers had to travel as much as forty miles to find a mill to grind their corn (BaCHS 1976: 53)." This seems an exaggeration in an area with such bad roads. It was more likely that intrepid pioneers used horses, or adapted the Native American practice of grinding stones before traveling that far. Nevertheless, mills were critical and millers came early. The Cox family, for instance, built a mill on Haw Creek close to their homestead soon after arrival. It was within 10 to 15 miles of Camp Atterbury residents and close enough for them to use, especially if they were willing to travel 40 miles, as indicated in one source (BaCHS 1976:52). 
Along the Driftwood River, mills were established almost as soon as the settlers arrived. J ohn Pence built a mill west of Taylorsville along the Driftwood River in 1822, which likely served Camp Atterbury settlers (BaCHS 1976:53). It was later purchased by Zachariah Tannehill whose family ran it until 1876 when Daniel Miller took over. This mill is just north of the Tannehill bridge on county roads $625 \mathrm{~N}$ and $650 \mathrm{~W}$, and eventually became the site of the Valley Roller Mills owned by the Drybreads (BaCHS 1976:53). Taylorville had its own grist and saw mill, which was destroyed by a boiler explosion around 1873 (BaCHS 1976:172). A little farther downstream, the Gale Mill (later Lowell mill) was established in 1836. The community of Lowell was built around it (remnants of it are seen at the bridge crossing County Road 265N).

Upstream along the Blue River (Section 33, Township 11 North, Range 5 East), just outside of Edinburgh, J ames Thompson built and operated a grist and saw mill in 1826 or 1827 (Banta 1888:533). By 1850 he had a large four-story brick mill that was considered the best in J ohnson County. Thompson's partner was Isaac Collier who first built a mill on Sugar Creek "just west of Edinburgh, about a half mile south of the Nineveh Road Bridge at the main (east) gate of Camp Atterbury" (Otto 1987:14). This mill is within Camp Atterbury at Section 32, Township 11 North, Range 5 East. Collier's Mill was both a grist and saw mill built around 1831 (J ohnson County Historical Society Vertical Files, "Mills"). Upstream in Section 20 along Sugar Creek was the Furnas or Foster Mill built around 1832 (J ohnson County Historical Society Vertical files, "Mills"). It was both a saw and grist mill also.

Like most good locations, several mills were built near Edinburgh, one after another, as the older mills were lost due to flooding or technology changed. Mills sprang up all over the region as more land was cleared and farmers moved beyond mere subsistence farming to cash crop farming and with the advent of steam power, mills could be built almost anywhere. By 1860, there were four flour mills in J ohnson County, 17 in Bartholomew County and two in Brown County in 1860 (U.S. Census 1860). There were also three saw mills in J ohnson County and 15 in Bartholomew County (U.S. Census of 1860).

Other industries included distilleries and tanneries. By 1835 Edinburgh had a distillery and in 1837 a tannery was established (Banta 1888:534). Edinburgh had a hominy mill in 1857, a woolen mill in 1863, a furniture factory in 1868, and foundry in 1868 (Banta 1888:535-536). Williamsburg 
also had a distillery and tannery around the mid 19th century (Banta 1888:558). In 1837, Edmund Mooney established a tannery 2 miles southwest of Kansas (BaCHS VF: Early Communities). One of the more important enterprises for the area was starch mills. The region's bumper corn crops provided the local entrepreneurs with the raw material for starch mills, and they grew to be very successful through the $19^{\text {th }}$ century. One of the first was the Blue River Starch Works established in 1868 (Banta 1888:537).

\section{Civil War}

Until the arrival of the U.S. Army in the 1940s, military activity was absent in Camp Atterbury and the rest of central Indiana. During peacetime, militias were formed, and during the Mexican War in the 1840s, patriotic volunteer residents of the tri-county area joined larger state regiments before marching off to war. Likewise, during the Civil War men volunteered for duty at first and were later drafted into regiments and marched south. Columbus became an important muster ground throughout the war. As men marched off, others formed Home Guards, or joined the Indiana Legion, where they learned the rudiments of military life. Unlike areas south of the Ohio River, the Camp Atterbury area did not experience the destruction to infrastructure, homes, industries, or crops caused by the Civil War.

Although many families of Bartholomew, J ohnson, and Brown Counties were transplants from the South, by the time of the Civil War, there was little support for the South, especially after the South had seceded from the Union. After secession, most of the debate centered around whether to let the Southern states secede or whether they should be coerced back. However, "In less than one week after the fall of Fort Sumter a company was organized in Bartholomew County" (BaCHS 1976:76). It would appear that residents in Bartholomew and J ohnson Counties were overwhelmingly Union.

Brown County was a different story. With its isolated rolling hills, the county developed a reputation as an area where people running from the law could lose themselves. During the Civil War, it was reputed to be the hiding place of deserters and draft dodgers. It was also a stronghold for "Copperheads," northerners who sympathized with the South or were against Lincoln (Thornbrough 1965:201). In 1863, there was a citizens' gathering in which a leading Democrat, Louis Prosser, shot a Union soldier and was then shot. According to Thornbrough, Prosser led a group of armed men into a Union rally and started the argument. Prosser shot a 
soldier and then was shot by a Union officer (Thornbrough 1965:201). However, a recent dissertation claims that Prosser was invited to speak at the rally and that Union soldiers arrived claiming to be in pursuit of deserters. A soldier instigated the violence when he attempted to disarm Prosser. Prosser shot him and was shot in return (Nicholson 1992:99100). In either case, southern sympathizers marched and drilled afterward in what became known as the Brown County war. While there were some incidents of harassment, outright warfare never surfaced. An investigation by the government after the Prosser incident revealed that Copperhead support was strong throughout the county.

Active warfare never entered Bartholomew, Brown, or J ohnson Counties. Citizens were on the alert at all times for the possibility of Confederates entering the state, and in J uly of 1863, their fears were realized when General J ohn Hunt Morgan lead around 2000 grey-clad soldiers across the Ohio River into Southern Indiana (Madison 1986:203). Morgan's raid pushed through Corydon and Salem, and then east toward Versailles, and then into Ohio. Word of Morgan spread northward to Columbus and the town's leaders prepared for the worst. Businesses closed, women and children were evacuated, and the men armed themselves with whatever guns they had. The local provost marshal, Colonel Simeon Stansifer, rallied them at the Second Street bridge on the west side of town, and they began to fortify a defensive position. The defenders included 50 men armed only with pitchforks. They waited all night, then a young man named Carruthers came riding across the bridge shouting that Morgan was coming. It seems Carruthers had been south of town gathering cows when he spotted a group of men riding for Columbus. He immediately assumed they were Morgan's men and rode ahead of them. Unfortunately for Carruthers, it turned out it was a posse of farmers who were on their way to town to join the defenders. Meanwhile, Morgan had turned east and never entered Bartholomew County (BaCHS 1976:212).

By the end of the war, some 231 privates and 12 officers from Bartholomew County had been killed in the war (BaCHS 1976:88). The county provided some 3263 men through volunteer and drafts; some of these would have been veterans re-enlisting (BaCHS 1976:89). 


\section{The pioneer landscape-summary}

The abundance of natural resources in the Camp Atterbury region provided well for the early settlers. Early farmers were looking for rich soils, which made the region to the north and east of Camp Atterbury more attractive. Because the land in Brown County and Nineveh Township Bartholomew County was not targeted by land speculators who drove up prices, it was settled later by people of fewer means (Nicholson1992:21). However, all of the necessities for a successful rural farming community were established early. The county system of government was almost immediately set in place, schools and churches were established early, mills and other necessities for farming were built, and roads were cut, and while subject to weather conditions, were passable. Rivers transported commodities to market and a rail system came early that provided a means to transport surplus farm commodities greater distances. The Civil War came and went, and while there had been the disruption and tragedy of fathers and sons lost in battle, the war had not severely impacted government, economy, society, or landscape. At the end of the pioneer period the region was a well ordered farming community with a prosperous future that had long shed its rustic pioneer setting. A promotional guide to Bartholomew County published in 1874 well summarizes the cultural landscape of Camp Atterbury:

\begin{abstract}
Her wealth and improvements have steadily increased rather in advance of her population. Fine dwellings and farms, fine churches and school houses, fine grist mills and manufacturing establishments, and fine towns and villages have sprung up all over the country as indications of wealth and prosperity, while the rude log structures used for churches and school houses, the old-fashioned horse mill and the fur trader have long since gone where the woodbine twineth (Cline \& McHaffie 1874:137).
\end{abstract}

J ohnson County was prospering and the area around the CAJ MTC had great potential. Some of that potential would not be realized until later when the land around the Driftwood River would be drained, but it was clear that the farms in this area were going to become large and productive. Finally, Brown County remained a rustic pioneer county and its landscape and culture remained closer to the pioneer era. While Bartholomew and J ohnson County farmers were expanding their yields as diversified farmers, Brown County farmers were subsisting, but doing well within the margins of the rolling hills. 


\section{Late 19th and Early 20th Century Landscape, 1870 - 1920}

\section{Introduction}

The 1870s began a new era in the settlement history of Camp Atterbury, marking the beginning of a period of established communities; prosperity and growth; cultural, social improvement and professional development; technological innovation, and peace. Unlike the American South, central Indiana had escaped the ravages of the Civil War and may have even prospered by providing corn and wheat to the U.S. Army. After the war, returning soldiers readapted to rural life or pushed west to find new land. Likewise, Reconstruction was a political issue to be discussed at the dinner table, not a transforming physical reconstruction of property and society like that being experienced in the South. Meanwhile, the initial purchase and settlement of the land had been largely completed. Instead of speculators and pioneers arriving and establishing homesteads, the landscape consisted of widely dispersed privately owned or rented farmsteads. Public property in the camp region was confined to school and county property. Farms actually were being divided as a new generation of Hoosiers was inheriting the land or businesses from their pioneer fathers.

Significant landscape changes had occurred since the arrival of the first settler to the tri-county region. The most visible change in 1870 was the cleared timber and creation of farm fields with homesteads defined by numerous crisscrossing rutty roads. In 1819, the land was occupied by Native Americans in widely dispersed small villages. There were a few rarely used trails through the heavy forest, but there were also numerous swamps and areas of heavy ground cover that had not been occupied for many years. In 1870, most of those areas were transformed with rutted or muddy trails and roads. In the northern part of Camp Atterbury, the farms were well distributed across a fairly open landscape. In 1875, some 39 percent of the state remained forested, but deforestation was already becoming a problem (Thornbrough 1965:364). Many of the farms still had old cabins built by the original settlers, but the cabins had become storage barns after new large two-story brick structures were built nearby. The rural landscape became dominated by these new home types, which served as testimony to the agricultural prosperity of the region. These brick homesteads clustered in the camp's J ohnson County and eastern Bar- 
tholomew County areas. An 1884 agricultural report noted that in Bartholomew County, "on nearly every road in the county may be seen fine large dwelling houses, in contrast with the little old log or frame houses standing near. Also, more convenient and capacious barns are taking the place of the old ones" (Annual Report, Indiana State Board of Agriculture, 1884:250, quoted in Phillips 1968:138). In the southern rolling hills of Camp Atterbury, the forests still dominated the landscape (Brown County in 1880 still was 57.3 percent forested [Thornbrough 1965:365]). Brown County farms were scattered, smaller, and resembled the earlier log structures of the Pioneer period.

The 1870s began with a severe economic depression, which continued throughout the decade and affected the lives of all Hoosiers (Thornbrough 1965:274). Nevertheless, the next 50 years were overall times of relative peace and prosperity, with steady progress toward improved roads, increased social organization, and improved education. Symbolic of the era, Bartholomew County constructed a four-story brick courthouse with full basement in Columbus. Completed in 1874, it still stands today (Marshall and Prather 2003:7-9). Change was driven primarily by technological changes in agriculture that increased yields.

\section{Population and Settlement}

By 1870, settlement across Camp Atterbury was dispersed, but fairly evenly distributed, with a slight increase in density in the northern portion (Figures 19, 20, 21, and 22). It is possible that the camp had reached its "carrying capacity" or maximum distribution and density. Surprisingly, population levels in most of the townships associated with Camp Atterbury reached their peaks in 1860 or 1870 . The data in Table 9 indicate that Nineveh Township in Bartholomew County dropped from 879 people in 1860 to 767 people in 1870 and the township's population continued to drop until 1920. Union Township, Bartholomew County, peaked at 1008 in 1870 and then dropped to a low of 445 in 1920 . The population in the more fertile lands of Nineveh Township, J ohnson County, peaked in 1860 at 1761 and continued to drop. The population of Hamblen Township, Brown County, dropped also, from a peak of 2011 in 1870 to 1331 in 1920. Only Blue River Township increased its population. This was unquestionably due to the growth of Edinburgh, combined possibly by land modifications near the Blue River, Sugar Creek, and the Driftwood River, which improved drainage and allowed for additional settlement. 


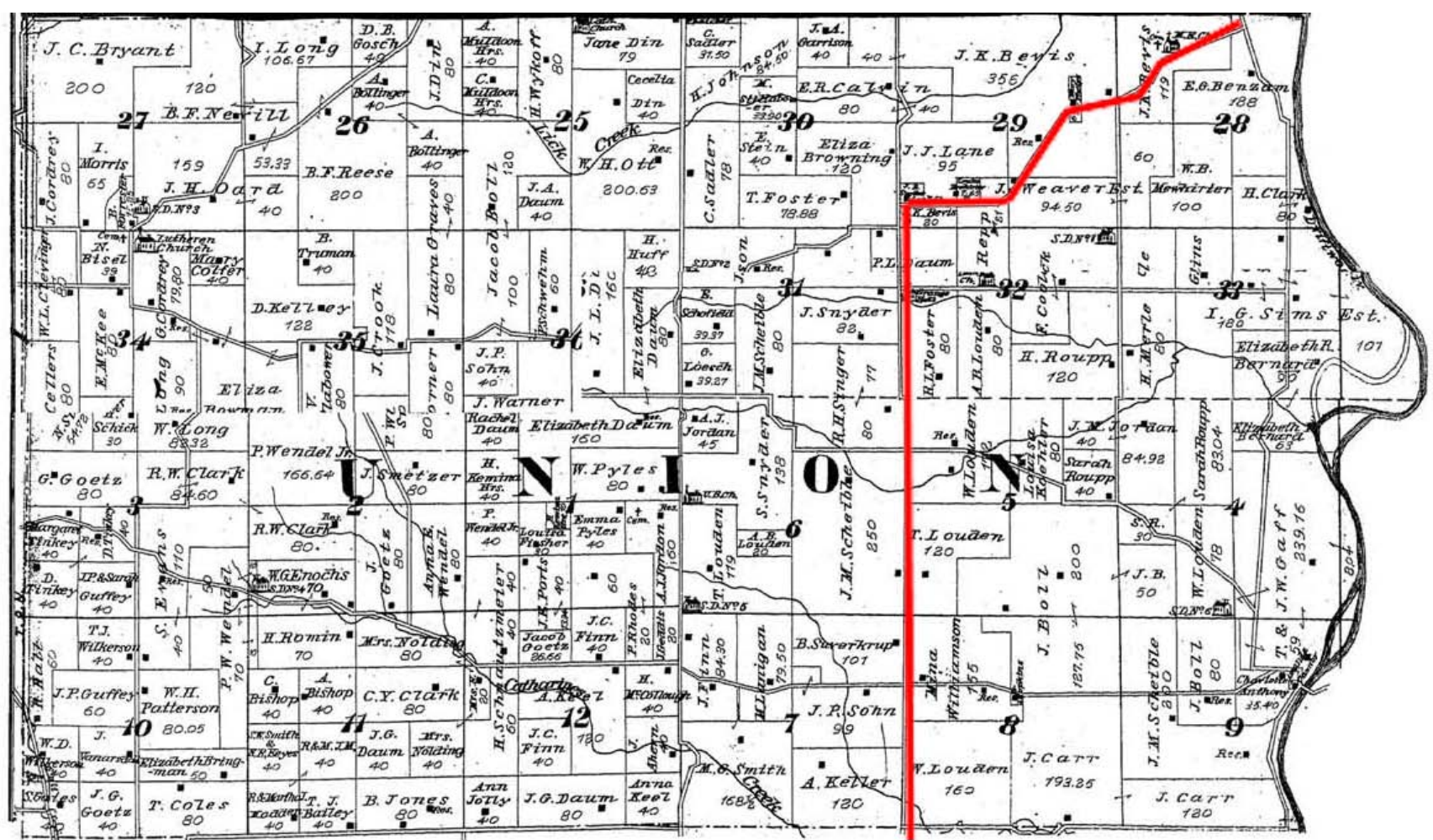

Figure 19. Landowners circa 1879, Union Township, Bartholomew County (courtesy Beers 1879:37).

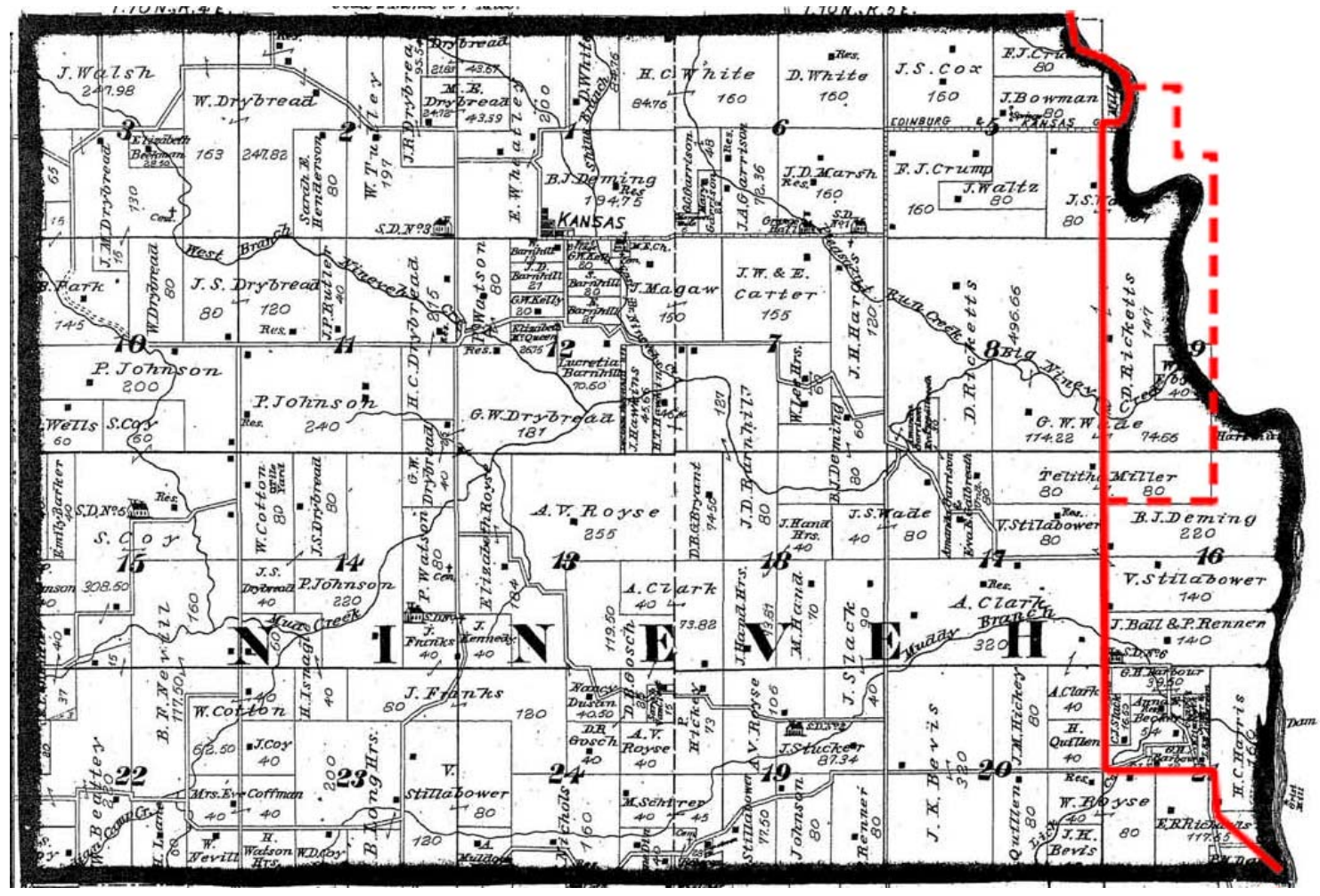

Figure 20. Landownership, circa 1879, Nineveh Township, Bartholomew County (courtesy Beers 1879:37). 


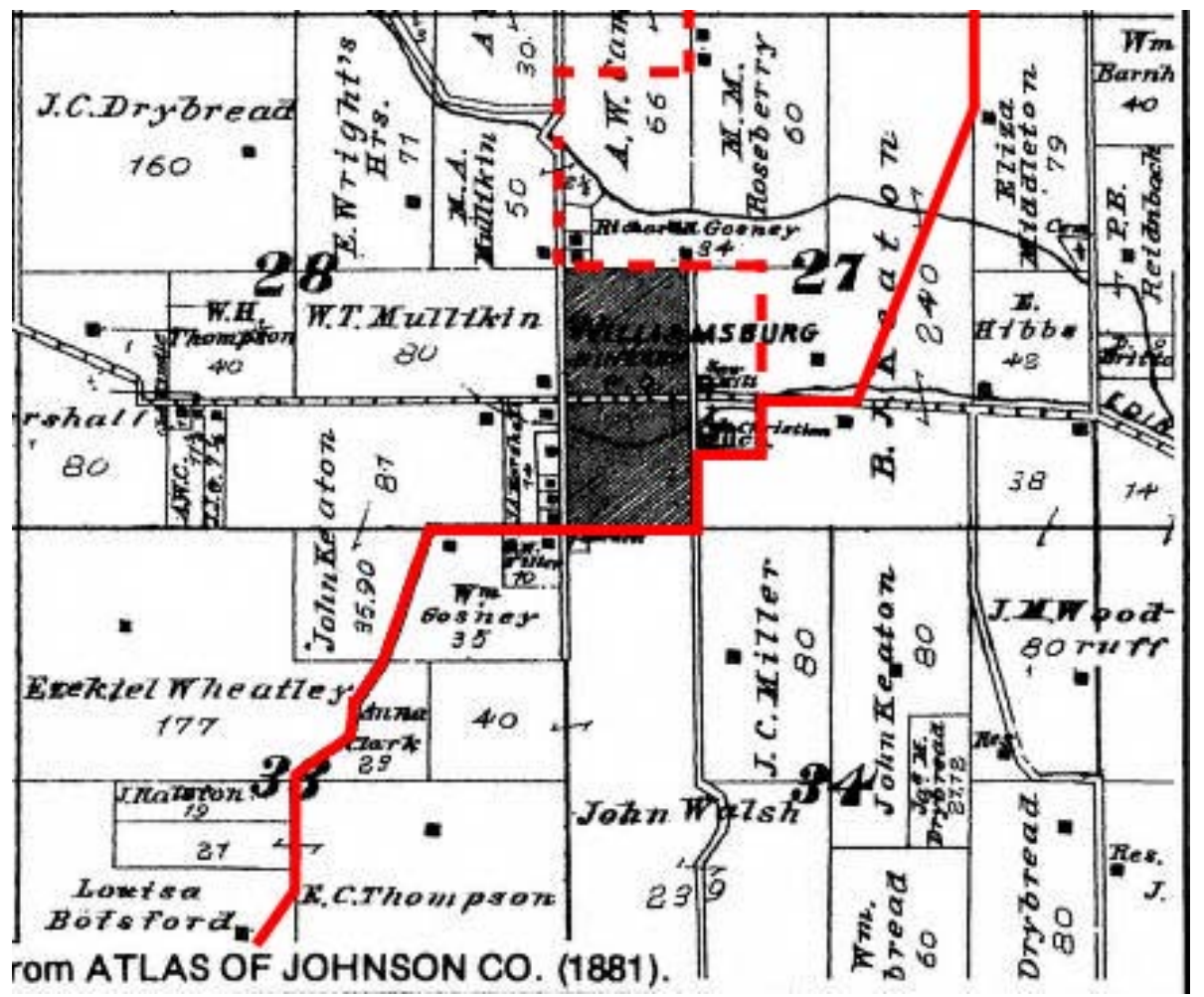

Figure 21. Enlargement of Landowner map, Nineveh Township, Johnson County, circa 1881 (courtesy Atlas of Johnson County).

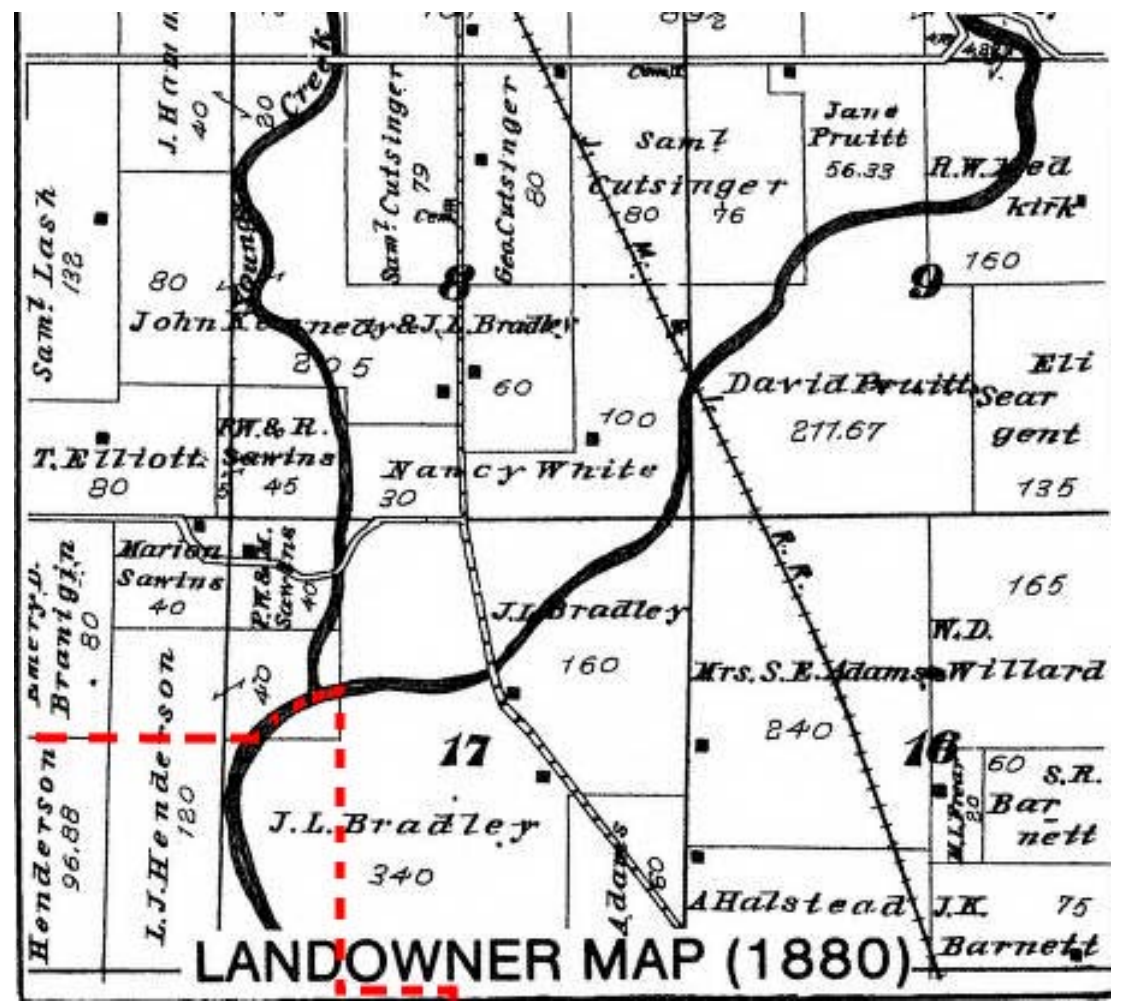

Figure 22. Enlargement of a portion of Blue River Township, Johnson County, circa 1881 at confluence of Sugar Creek and Blue River. (courtesy Atlas of Johnson County). 
Table 9. Population of townships incorporating Camp Atterbury from 1870 to 1920 . Numbers in parentheses indicates Black population.

\begin{tabular}{|l|l|l|l|c|c|c|c|}
\hline County & Township & 1870 Census & $\mathbf{1 8 8 0 \text { Census }}$ & $\begin{array}{c}1890 \\
\text { Census }\end{array}$ & $\begin{array}{c}1900 \\
\text { Census }\end{array}$ & $\begin{array}{c}1910 \\
\text { Census }\end{array}$ & $\begin{array}{c}1920 \\
\text { Census }\end{array}$ \\
\hline Bartholomew & & $21,133(11)$ & $22,777(138)$ & $23,867(314)$ & $24,594(335)$ & $24,813(319)$ & $23,887(229)$ \\
\hline Bartholomew & Nineveh & $767(0)$ & - & 697 & 624 & 577 & 529 \\
\hline Bartholomew & Union & $1,008(0)$ & - & 737 & 641 & 570 & 445 \\
\hline Johnson & & $18,366(115)$ & $19,537(354)$ & $19,561(342)$ & $20,223(418)$ & 20,391 & 20,739 \\
\hline Johnson & Nineveh & $1,650(0)$ & - & 1,523 & 1,393 & 1,288 & 1,187 \\
\hline Johnson & Blue River & $2,573(25)$ & - & 2,792 & 2,589 & 2,815 & 3,088 \\
\hline Brown & & $8,681(1)$ & $10,264(0)$ & $10,308(7)$ & $9,727(1)$ & $7,975(1)$ & $7,019(1)$ \\
\hline Brown & Hamblen & 2,011 & - & 1,959 & 1,923 & 1,524 & 1,331 \\
\hline
\end{tabular}

The reason for the population loss in Bartholomew and J ohnson Counties is not known. Possibly, it was due to continued out-migration of farmer's sons seeking their own land in the western states, or the result of better opportunities in growing urban areas like Indianapolis (Philips 1965:364366; Salstrom 2007:118-119). Note that county populations continued to slowly grow in the late $19^{\text {th }}$ century. After 1900, populations stabilized in Bartholomew and J ohnson Counties. Brown County's population loss was due to soil depletion making farming unprofitable.

Historians write that Brown County was a rugged land with relatively poor soils and scattered population. Certainly, Brown County had a smaller population than J ohnson and Bartholomew Counties. Historian Howard Nicholson noted that Brown County population decreased by 25 percent between 1890 and 1910, due largely to an agricultural depression and the erosion of fertile soils from lumbering (see below) (Nicholson 1992:122). Township population analysis agrees with that assessment (includes men, women, and children). Hamblen Township had the largest population of the townships that make up Camp Atterbury.

However, the township is nearly twice as large as Nineveh Township, J ohnson County (Hamblen has 64 sections, while Nineveh has 36), and nearly three times as large as Nineveh Township, Bartholomew County (22 sections). Assuming an average density per section spread over these townships (or per square mile) dividing the population into the area provides the following township population comparisons for 1870:

(1) Hamblen Township, Brown County, 31 persons per square mile;

(2) Nineveh, J ohnson County, 46 persons per square mile; (3) Nineveh Township, Bartholomew County, 35 persons per square mile; and (4) Union Township, Bartholomew 42 persons per square mile. Hamblen 
did have the fewest people per square mile, but not dramatically fewer than Bartholomew. Meanwhile, Union Township population density, along the Ohio Ridge, compared well with the rich soils of Nineveh Township in Johnson County.

By 1920, the population density dropped to the following numbers:

(1) Hamblen Township, 21 persons per square mile; (2) Nineveh Township, J ohnson County, 32 per square mile; (3) Nineveh Township, Bartholomew County, 24 per square mile; and (4) Union Township, 18 per square mile. (Blue River Township is not included because it contains Edinburgh.) Each township lost around 10 persons per square mile by 1920 except for Union Township. That township's population had dropped by nearly 25 persons per square mile. Compared to the rest of Indiana in 1913, J ohnson County's overall rural population was 49.4 persons per square mile (Branigin 1913:537).

While one cannot determine exactly how many people lived within Camp Atterbury between 1870 and 1930, the data provides the opportunity to make educated guesses. The average population for the period for each township was as follows: (1) Bartholomew-Nineveh, 28 persons per square mile; (2) Bartholomew-Union, 28 per square mile; (3) J ohnson-Nineveh, 39 per square mile; and (4) Brown- Hamblen, 27.3 per square mile. Interestingly, except for the fertile lands in J ohnson County's Nineveh Township, the three other townships were all around 28 people per square mile (again, leaving out Blue River because of Edinburgh). Therefore it is reasonable to assume that, for most of the camp as defined today, the average was indeed 28 per square mile, or around 1428 persons on average per year living within Camp Atterbury during the period between 1870 and $1920(33,132$ acres $=51$ square miles $)$.

Camp Atterbury remained rural through this period. Except for Williamsburg-Nineveh, just outside Camp Atterbury, and Kansas, there were no other hamlets associated with Camp Atterbury. Other areas of the camp had local names including Ohio Ridge, Hog Bottom, and Pisgah, but these were place names of churches and school rather than clustered settlements. Edinburgh, Taylorsville, and Columbus remained the urban centers that served the Camp Atterbury region. 


\section{Agricultural Life}

Much of the farming in Bartholomew County during the latter part of the $19^{\text {th }}$ century and about a dozen years into the next century could be described as subsistence farming - a way to make a living and little else. Farms were small, averaging around 80 acres. Large original land holdings had been broken up by the custom of dividing land equally among offspring, and farm families quite often were large. For the most part, labor was family help (Marshall and Prather 2003:61).

The above quote is from the 2003 Bartholomew County history. Although this description might be characteristic of the Camp Atterbury hills region, agricultural census data indicates that for Bartholomew County as a whole, and extending to the tri-county region, farm productivity was better than subsistence level. For example, in 1919, 79.6 percent of the corn, 76.5 percent of the hay, and 69.9 percent of the oats grown in Indiana was consumed on the farm rather than sold indicating that the farmers were self sufficient (Philips 1968:150). Still, census data clearly reveals that the tri-county regional farms were harvesting a cash crop and selling it in a market economy (Tables 10 and 11).

The average farm size recorded by Marshall and Prather is also suspect. The 1880 census indicates that there were 2207 farms in Bartholomew County, cultivating 240,746 acres, for an average farm size of 109 acres. The 1900 census notes that there were 2431 farms cultivating 254,051 acres or an average of 104 acres, and the 1910 figures were 2127 farms cultivating 244,900 acres or 115 acres. At no time was the average farm size less than 100 acres. It is possible that the authors meant the median size of farms was 80 acres, but even then the census data do not appear to support that contention (Tables 10 and 11).

The Census of Agriculture during this period records the bountiful production of the three counties (Tables 10 and 11). These statistics indicate that corn and swine were still the mainstays of the cash crops in the three counties. Some of the corn was being used to feed the swine, however, from the number of mills and starch factories, the counties produced a lot of grain and other food crops. All in all, the evidence paints a picture of prosperity and of farms actively participating in a national and international market economy.

Bartholomew and J ohnson Counties were in Indiana's heart of sweet corn production (Philips 1968:155). A People's Guide noted that in 1874, Bar- 
tholomew County was "the banner corn county of the state" (Cline and McHaffie 1874:133). Meanwhile, their northern neighbors were also "Corn Kings." The superintendent of schools for J ohnson County wrote in 1914 that:

No county in the world has merited and received more honors for really great contribution to scientific agriculture than J ohnson County through the work of her Corn Kings. The grand champion sweepstakes on 10 ears of White Dent at the national show in Omaha was won in 1908, as well as grand champion sweepstakes on a single ear of corn, which was purchased from the grower for $\$ 250$.

The grand champion trophies continued to be awarded to J ohnson County corn farmers for all but 2 years between 1906 to 1920 (Blake n.d.:7).

Table 10. Selected crop production in the tri-county region of Camp Atterbury, 1880 to 1920.

\begin{tabular}{|l|l|l|l|l|l|l|c|c|}
\hline County & Wheat & $\begin{array}{l}\text { Rye and } \\
\text { Oats* }\end{array}$ & Corn & Potatoes & Wool & Hay tons & Tobacco & Butter/Cheese \\
\hline Bartholomew 1880 & 672,947 & 100,817 & $1,842,869$ & 36,688 & 43,713 & - & 37,364 & 410,699 \\
\hline Bartholomew 1890 & 690,898 & 192,889 & $1,836,694$ & 78,906 & - & 25,268 & 3,271 & 473,450 \\
\hline Bartholomew 1900 & 765,930 & 138,300 & $1,804,840$ & 54,141 & 47,284 & - & 4,420 & 514,030 \\
\hline Bartholomew 1910 & 696,101 & 90,174 & $2,358,155$ & 56,713 & - & - & 14,145 & 410,337 \\
\hline Bartholomew 1920 & 923,718 & 172,692 & $1,766,771$ & 20,305 & 17,024 & - & 3,631 & 168,000 \\
\hline Johnson 1880 & 649,937 & 49,941 & $1,987,379$ & 38,147 & 4,226 & - & 3,935 & 417,986 \\
\hline Johnson 1890 & 512,854 & 145,406 & $1,718,643$ & 50,296 & - & 24,639 & 10,300 & 484,676 \\
\hline Johnson 1900 & 537,320 & 47,260 & $2,259,930$ & 23,245 & 8,035 & - & 22,600 & 551,574 \\
\hline Johnson 1910 & 640,831 & 93,077 & $2,982,253$ & 33,842 & - & - & 47,128 & 491,849 \\
\hline Johnson 1920 & 966,749 & 98,414 & $1,656,668$ & 2,903 & 2,634 & - & 7,230 & 140,770 \\
\hline Brown 1880 & 67,380 & 71,781 & 314,124 & 29,665 & 4,009 & - & 190,265 & 240,948 \\
\hline Brown 1890 & 67,464 & 74,855 & 357,103 & 45,538 & - & 10,053 & 18,402 & 333,535 \\
\hline Brown 1900 & 107,830 & 33,810 & 344,590 & 35,296 & 4,081 & - & 22,750 & 227,103 \\
\hline Brown 1910 & 58,298 & 35,795 & 426,558 & 59,856 & - & - & 7,003 & 222,725 \\
\hline Brown 1920 & 57,104 & 39,602 & 366,805 & 15,066 & 1,003 & - & 12,933 & 144,074 \\
\hline *After 1900 this statistic is mostly oats. Wheat, oats, corn, potatoes in bushels, butter/cheese and tobacco in pounds. \\
\hline
\end{tabular}

Table 11. Selected livestock production in the tri-county region of Camp Atterbury, 1880 to 1920.

\begin{tabular}{|l|c|r|r|l|}
\hline County & Horses/Mules & \multicolumn{1}{l|}{ Cattle } & \multicolumn{1}{l|}{ Sheep } & Swine \\
\hline Bartholomew 1880 & 7,408 & - & 6,879 & 37,749 \\
\hline Bartholomew 1890 & 9,000 & 15,824 & - & 34,916 \\
\hline Bartholomew 1900 & 9,782 & 16,452 & 11,098 & 39,112 \\
\hline Bartholomew 1910 & 9,909 & 11,840 & 8,120 & 30,041 \\
\hline Bartholomew 1920 & 9,278 & 15,460 & 4,131 & 45,413 \\
\hline
\end{tabular}




\begin{tabular}{|l|c|r|r|r|}
\hline County & Horses/Mules & \multicolumn{1}{l|}{ Cattle } & \multicolumn{1}{l|}{ Sheep } & \multicolumn{1}{l|}{ Swine } \\
\hline Johnson 1880 & 7,489 & - & 6,213 & 45,800 \\
\hline Johnson 1890 & 9,240 & 16,428 & - & 49,866 \\
\hline Johnson 1900 & 8,870 & 19,530 & 18,190 & 56,218 \\
\hline Johnson 1910 & 10,701 & 16,019 & 11,596 & 41,335 \\
\hline Johnson 1920 & 10,306 & 17,548 & 4,999 & 55,187 \\
\hline Brown 1880 & 3,251 & - & 6,189 & 13,479 \\
\hline Brown 1890 & 3,526 & 8,598 & - & 11,894 \\
\hline Brown 1900 & 4,219 & 7,142 & 11,626 & 9,474 \\
\hline Brown 1910 & 3,556 & 5,014 & 5,675 & 5,382 \\
\hline Brown 1920 & 3,471 & 5,609 & 2,066 & 7,787 \\
\hline
\end{tabular}

Nearly all farms in 1890 were owner-operated, but shared and rented farms increased through the period. The lowest percentage of private ownership was J ohnson County of 49 percent in 1900 (Table 12, 13, and 14); but all three counties had low ownership at that time, Bartholomew being only 52 percent and Brown County only 66 percent (Tables 15, 16, and 17).

Indiana farmers may have been victims of their own success. As yields increased, prices went down. This drove farmers to clear and farm more land, increasing the need for mechanization. Farmers increased their debt by mortgaging their homes and land to purchase equipment. As swamplands were drained to increase the amount of land available, prices dipped further. Exacerbating the situation were national policies like protective tariffs and rising freight costs (American Guide Series 1941:69-71). However, Bartholomew and J ohnson Counties were part of a bigger trend in farm production and farm values across Indiana and the nation.

Table 12. Farm size for owner-operated farms in the tri-county Camp Atterbury region, 1890.

\begin{tabular}{|l|c|c|c|c|c|c|c|c|c|}
\hline Counties in 1890 & Under 10 & $\mathbf{1 0}$ to 19 & $\mathbf{2 0}$ to 49 & $\mathbf{5 0}$ to 99 & $\mathbf{1 0 0}$ to 500 & 500 to 999 & Over 1000 & Total Owner & Total Farms \\
\hline Bartholomew & 53 & 51 & 305 & 481 & 710 & 17 & 4 & $1,621(76 \%)$ & 2,129 \\
\hline Brown & 11 & 28 & 378 & 455 & 505 & 12 & 3 & $1,392(87 \%)$ & 1,601 \\
\hline Johnson & 64 & 75 & 290 & 383 & 484 & 6 & 1 & $1,303(68 \%)$ & 1,920 \\
\hline
\end{tabular}

Table 13. Farm size for fixed rent farms in the tri-county Camp Atterbury region, 1890.

\begin{tabular}{|l|c|c|c|c|c|c|c|c|}
\hline Counties in 1890 & Under 10 & 10 to 19 & 20 to 49 & 50 to 99 & 100 to 500 & 500 to 999 & Over 1000 & Totals \\
\hline Bartholomew & 7 & 6 & 13 & 28 & 49 & 1 & 0 & $104(5 \%)$ \\
\hline Brown & 0 & 4 & 13 & 8 & 8 & 0 & 0 & $33(2 \%)$ \\
\hline Johnson & 20 & 5 & 26 & 43 & 37 & 0 & 0 & $131(7 \%)$ \\
\hline
\end{tabular}

Table 14. Farm size for share rented farms in the tri-county Camp Atterbury region, 1890.

\begin{tabular}{|l|c|c|c|c|c|c|c|l|}
\hline Counties in 1890 & Under 10 & 10 to 19 & 20 to 49 & 50 to 99 & 100 to 500 & 500 to 999 & Over 1000 & Totals \\
\hline Bartholomew & 4 & 11 & 71 & 140 & 173 & 5 & 0 & $404(19 \%)$ \\
\hline Brown & 4 & 9 & 53 & 61 & 49 & 0 & 0 & $176(11 \%)$ \\
\hline Johnson & 4 & 15 & 102 & 165 & 197 & 3 & 0 & $486(25 \%)$ \\
\hline
\end{tabular}


Table 15. Owner operator farm size in Bartholomew County, 1900 through 1920.

\begin{tabular}{|l|c|c|c|c|c|c|c|c|c|}
\hline Bartholomew County & Under 10 & $\mathbf{1 0}$ to 49 & $\mathbf{5 0}$ to 99 & $\mathbf{1 0 0}$ to 174 & $\mathbf{1 7 5}$ to 259 & $\mathbf{2 6 0}$ to 499 & $\mathbf{5 0 0} \&$ Over & Total Owner & Total Farms \\
\hline 1900 & 135 & 602 & 656 & 692 & 221 & 105 & 20 & $1,281(52 \%)$ & 2,431 \\
\hline 1910 & 73 & 434 & 581 & 655 & 255 & 106 & 23 & $1,474(69 \%)$ & 2,127 \\
\hline 1920 & 64 & 387 & 568 & 655 & 237 & 107 & 25 & $1,380(68 \%)$ & 2,043 \\
\hline
\end{tabular}

Table 16. Owner operator farm size in Brown County, 1900 through 1920.

\begin{tabular}{|l|c|c|c|c|c|c|c|c|c|}
\hline Brown County & Under 10 & 10 to 49 & 50 to 99 & $\mathbf{1 0 0}$ to 174 & $\mathbf{1 7 5}$ to 259 & $\mathbf{2 6 0}$ to 499 & $\mathbf{5 0 0} \&$ Over & Total Owner & Total Farms \\
\hline 1900 & 54 & 493 & 623 & 425 & 155 & 59 & 16 & $1,208(66 \%)$ & 1,825 \\
\hline 1910 & 30 & 355 & 487 & 419 & 133 & 67 & 10 & $1,221(81 \%)$ & 1,501 \\
\hline 1920 & 36 & 314 & 468 & 409 & 152 & 66 & 13 & $1,169(80 \%)$ & 1,458 \\
\hline
\end{tabular}

Table 17. Owner operator farm size in Johnson County, 1900 through 1920.

\begin{tabular}{|l|c|c|c|c|c|c|c|c|c|}
\hline Johnson County & Under 10 & $\mathbf{1 0}$ to 49 & $\mathbf{5 0}$ to 99 & $\mathbf{1 0 0}$ to 174 & $\mathbf{1 7 5}$ to 259 & $\mathbf{2 6 0}$ to 499 & $\mathbf{5 0 0} \&$ Over & Total Owner & Total Farms \\
\hline 1900 & 100 & 566 & 653 & 487 & 155 & 82 & 10 & $998(49 \%)$ & 2,053 \\
\hline 1910 & 136 & 449 & 673 & 507 & 168 & 84 & 8 & $1,301(64 \%)$ & 2,025 \\
\hline 1920 & 164 & 426 & 659 & 558 & 171 & 67 & 6 & $1,259(61 \%)$ & 2,051 \\
\hline
\end{tabular}

At the turn of the 20th century, Midwestern agriculture was in its "golden age" (Phillips 1968:132). Farm sizes averaged 100 acres in Indiana, which as seen above, fit the Bartholomew and J ohnson County averages (Phillips 1968:134). Further, the slow increase in cash and share renters is not to be confused with the tenant system in the South, where landless poor whites and blacks were tied to cotton agriculture and faced continual debt. Midwestern tenants, including Indiana's, resulted from:

"high-priced rather than low-priced land, and to the raising of hay, grain, and hogs....A U.S. Department of Agriculture study of three townships in central Indiana in the summer of 1911 suggests that farm tenants there were making a fair return on capital invested" (Phillips 1968:136).

In other words, farming was profitable either as a landowner or a renter.

Early $19^{\text {th }}$ century observers of western Bartholomew County had noted that while the soils were poor, the land was ideal for fruit growing. This was repeated in an 1874 People's Guide to the county (Cline and McHaffie 1874:133). Along Catherine Creek the 330 acre Allison orchard was established around 1901. It thrived during the 1930s (Marshall and Prather 2003:91). However, census information does not indicate that fruit was an especially large market crop in the tri-county region. The 1890 census noted that Bartholomew County produced 107,980 bushels of apples, Brown County produced 88,925, and J ohnson County produced 47,720, while the 1900 census recorded 56,334, 23,592, and 55,985 bushels respectively (U.S. Census of Agriculture 1890 and 1900). 
Farm mechanization changed the fortunes of the tri-county area slowly, but steadily. There was considerable technological advancement in farm machinery from 1820 to 1870, including new sturdier plows that helped break the Tipton Plain prairie soils. Harvesters, cultivators, and threshers also were developed, but the peak of agricultural mechanization was in the latter part of the $19^{\text {th }}$ century. "In the eighties and nineties a multiplicity of new or improved farm machines were introduced into the state, including the riding gang plow, disk plow, manure spreader, twine binder, fertilizer drill, side-delivery hay rake and the two-row corn cultivator. Two machines particularly important for Indiana agriculture, the corn binder and corn picker, were added in the first two decades of the $20^{\text {th }}$ century" (Philips 1968:139). Historians noted that farmers in the hills country did not adapt rapidly to these machines for economic reasons, while it was the more prosperous farmers in the Tipton plains that were able to purchase new equipment and increase their yields (Nicholson 1992:125-128).

The purchase of a harvester or thresher not only increased the farmer's production, it increased his status in the community. Threshing "rings" developed, consisting of a group of farmers sharing the thresher and working together in an annual round to harvest their crops. Wheat threshing, usually in J uly, became an important community event. The men divided into work teams while the women cooked and the children assisted with chores. When finished they moved on to another farm. Where the farms were small and crops were harvested in less than a day, the farmers did several farms a day and at the end of the season, they would all gather for a "thresher's picnic" (Marshall and Prather 2003:63-63). Threshing built and strengthened community ties, but also divided the community between those who shared the machines and those who did not (Nicholson 1992:130), defining communities by those within and outside of the threshing teams.

The science of agriculture in the early $20^{\text {th }}$ century improved and the prosperous farmers began to practice soil renewal, fertilization, and crop rotation (Figure 23). Mechanization and scientific farming was championed at the newly established agricultural school at Purdue University in 1879. The State Agricultural Board was established and a farmer's institute was built by the board in Columbus in 1882. It took several years before it was widely attended (Philips 1968:142-144). In 1914, the Federal government passed the Smith-Lever Act. This act provided funding for agricultural specialists at the county level who distributed information about new farming practices. These county "extension" agents were not fully em- 
braced immediately, but eventually farmers saw the benefits of their service. Home Economic clubs, Home Demonstration Clubs and 4-H programs were started during this period (Marshall and Prather 1968:76).

\section{Late $19^{\text {th }}$ century social organization}

Circuit riders still traveled through the counties during the 1870s and 1880s, but most religious people joined and attended churches. Newly formed congregations of the various Protestant and Catholic denominations moved from private homes to separate church buildings at this time while congregations established during the Pioneer period began to build more substantial structures. In Columbus, Franklin, and Edinburgh, for instance, the congregations built elaborate brick edifices that still stand today. In the rural areas, the wood frame churches built in the 1850s and 1860 s were still used in the late $19^{\text {th }}$ century, while some were remodeled or replaced (Figures 24, 25, and 26). At Kansas, a Christian church was organized in 1876 by Elder A. Elmore and a brick structure was built immediately. Interestingly, this church was blown down and replaced with a wood frame building. The church served the people until Camp Atterbury was established (BaCHS 1976:117).

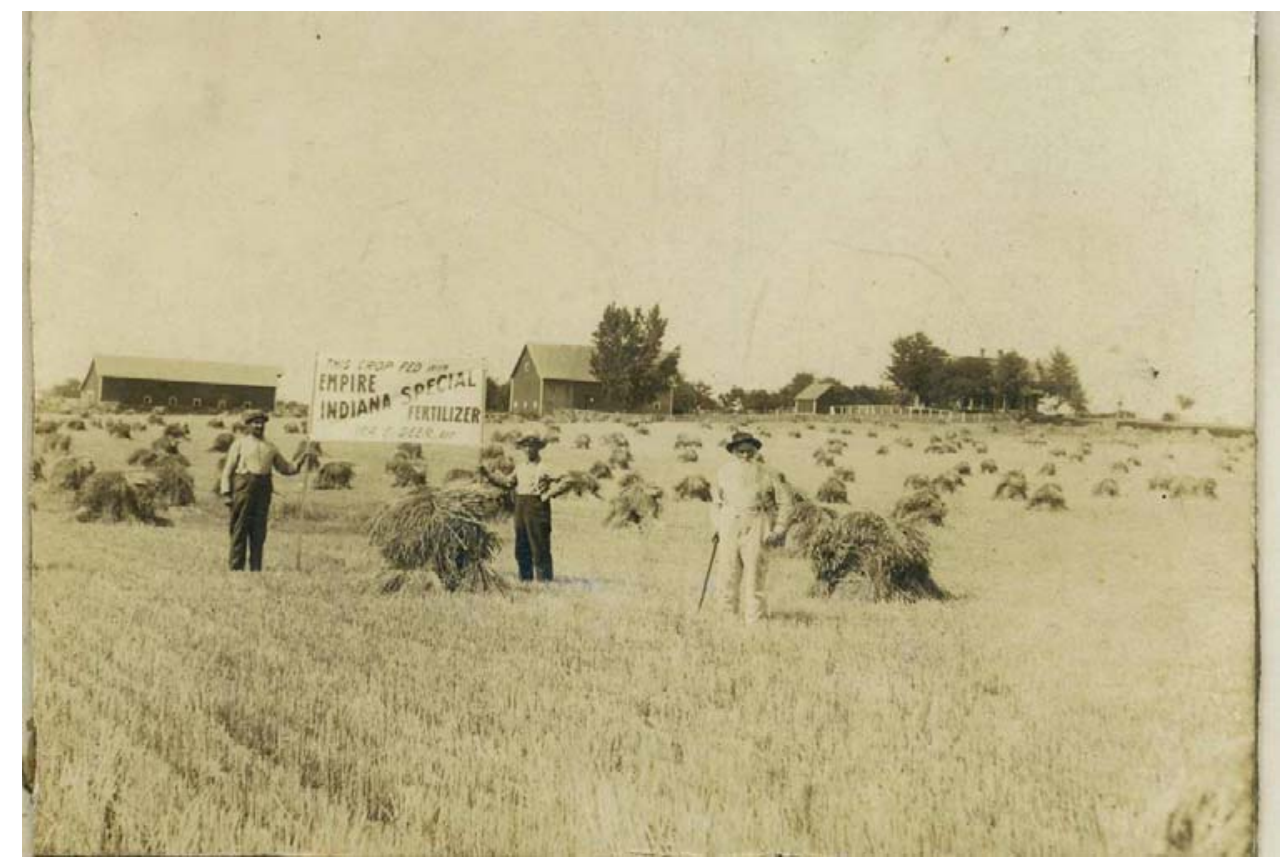

Figure 23. Thomas Blackwell farm in 1916, farm laborers holding banner championing Empire Fertilizer. (Courtesy Johnson County Historical Society, Franklin, IN). 


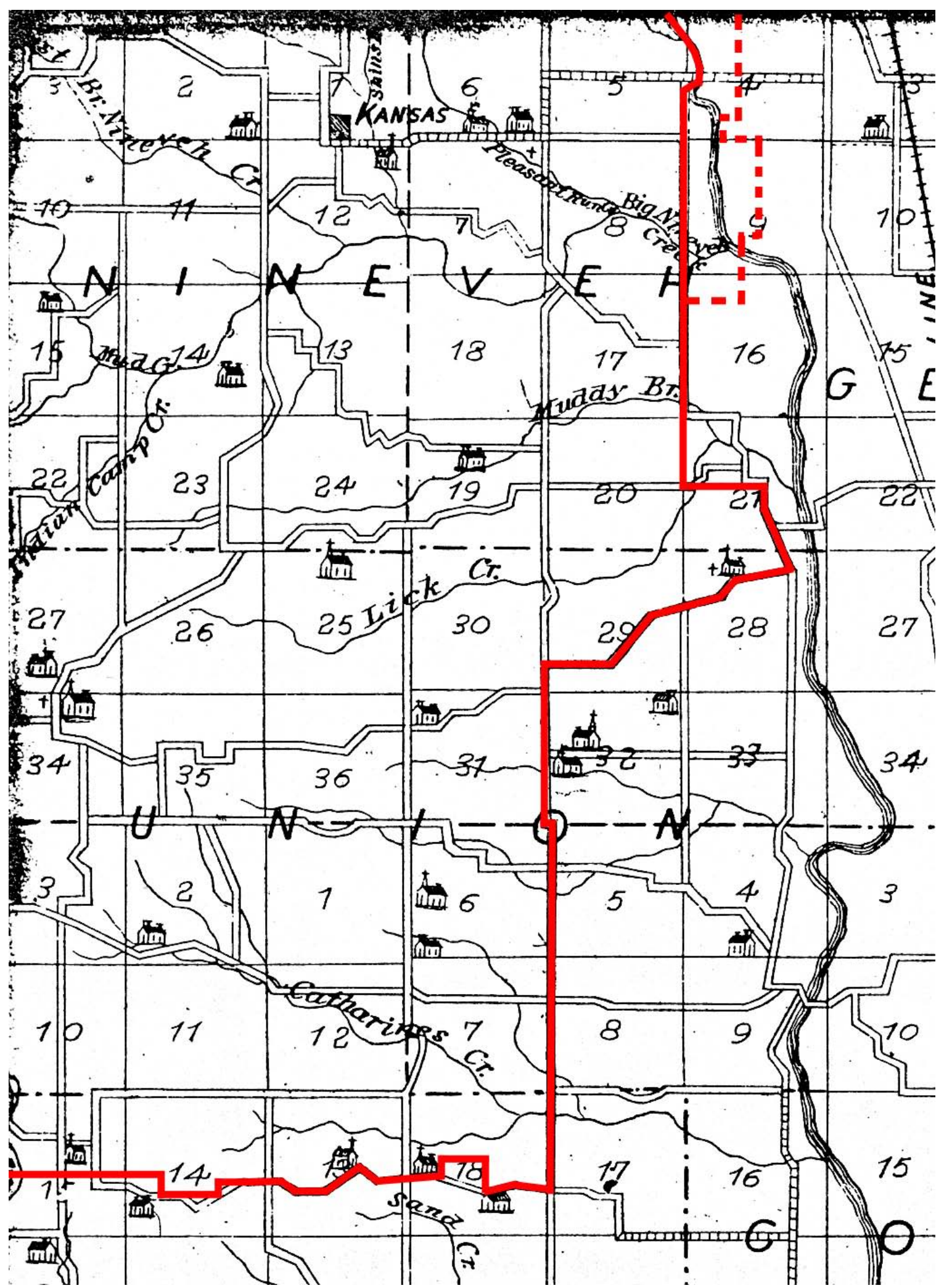

Figure 24. Churches, Schools, and road network, Nineveh and Union Townships, Bartholomew County, circa 1888 (courtesy BaCHS 1976:front inset). 


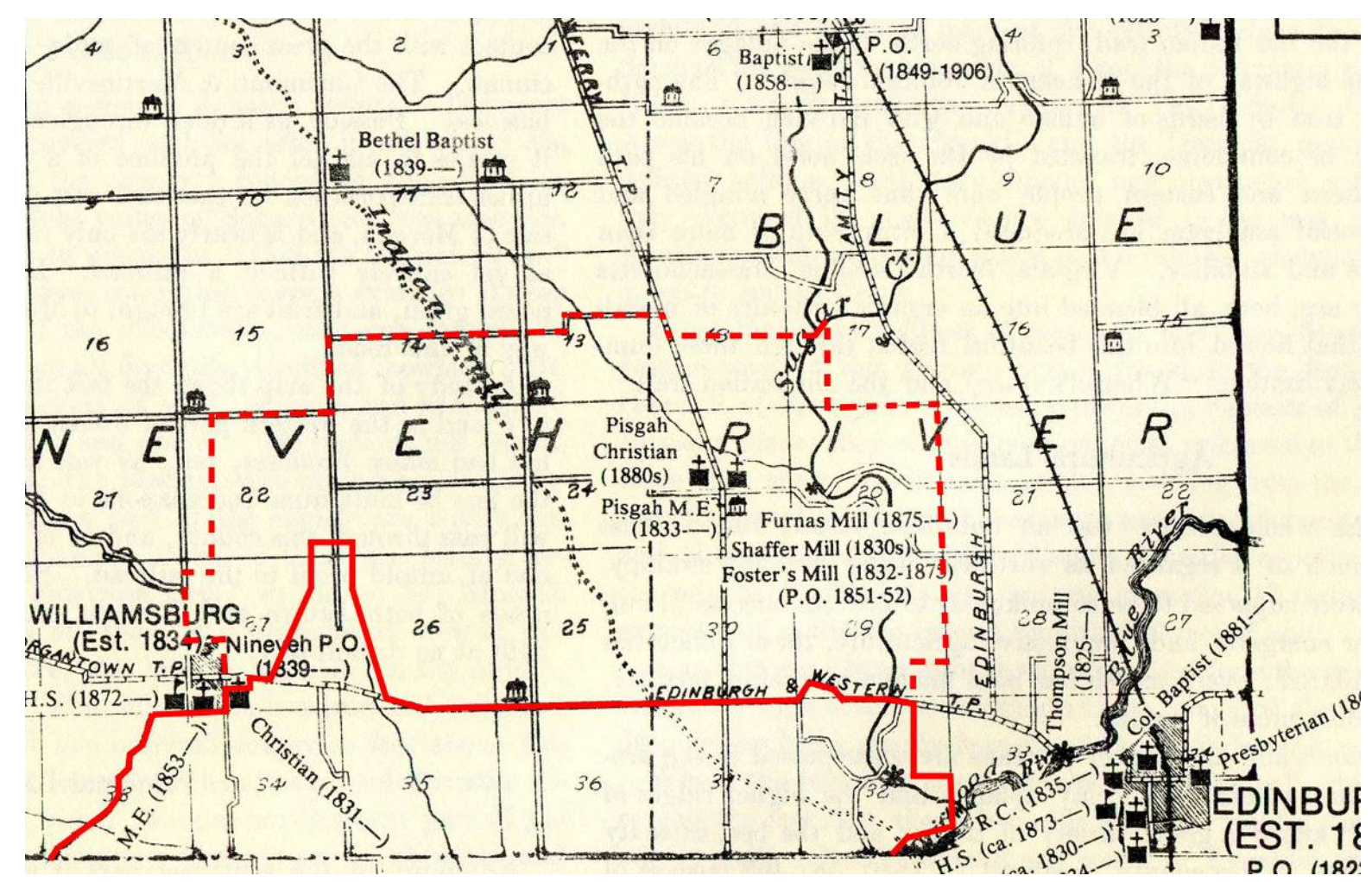

Figure 25. Churches, Schools, road network, Nineveh and Blue River Townships, Johnson County, circa 1881 (courtesy Atlas of Johnson County).

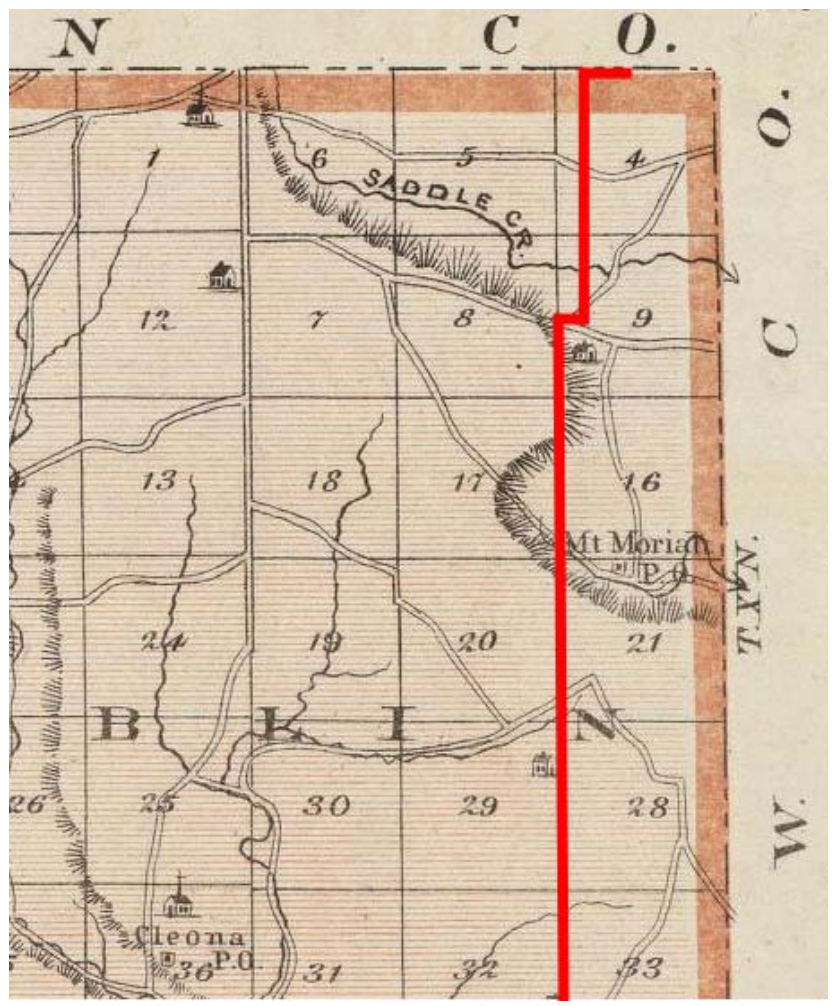

Figure 26. Churches, schools, and roads, Hamblen Township, Brown County, circa 1876. 
On the Ohio Ridge Lutherans and United Brethren had shared a building from the Pioneer period. A second church was built in 1871 and repaired in 1896 and 1906 (Stott 1980:2), but building the new church caused a riff in the community when the Lutheran minister thought that the building should no longer be shared with the United Brethren. Other Lutherans disagreed. The Brethren moved out to the local school, but the controversy split the remaining Lutherans and reduced membership to such an extent that in 1898, the remaining Lutherans asked the local Methodists if they would include their church on the Methodist circuit and the Methodists agreed (Stott 1980:3). Besides the St. Mathew's Lutheran Church in 1874, Union Township had a St. J ohn's Lutheran church, and the Bethany M.E. church (Cline and McHaffie 1874:345-346). In the late 1870s, Union Township also had a Catholic church (Marshal and Prather 2003:162).

In Nineveh Township, J ohnson County, most of the churches originally established during pioneer days continued to flourish. The Williamsburg Christian congregation built a brick structure in 1860. There was a major controversy in 1890 when the church purchased an organ. Part of the congregation threatened to quit the church because it was thought to be against Biblical teaching (Hibbs 2007:45). The church was remodeled in 1905 and served until the 1950s (Hibbs 2007:51). The Methodists also had a church at Nineveh as well as another at Pisgah (see the "Towns" section, p 85). Across Camp Atterbury, church cemeteries were established next to the churches. Families were sometimes charged for burial plots. For instance, in 1895 at St. Mathews in Union Township, Bartholomew County, grave sites sold for 25 cents, 50 cents, and \$1.00.

Public schools improved throughout the period and subscription schools faded from the landscape. Some of the improvements were initiatives started in the Pioneer period. At that time the state legislature passed a series of laws establishing regulations and taxation for public schools. One law in 1867 allowed schools to be open eight to 10 months a year. Several Normal, or teaching schools, opened to standardize requirements for the teaching profession. School reform continued during the late $19^{\text {th }}$ century and, in 1873, the state established county superintendents and county boards of education, increasing standardization in teaching, curricula, and text books (BaCHS 1976:139). From 1883 to 1885, Indiana laws came to require licenses for teachers and physicians (Nicholson 1992:134).

These acts pushed forward educational progress and as a secondary benefit, in combination with churches, strengthened a sense of community 
among people living in Camp Atterbury. In 1895, the Columbus Republic announced that Nineveh Township, Bartholomew County, School No. 1, held commencement at the Kansas, M. E. church, "Saturday evening and notwithstanding the rainy evening the house was crowded to its utmost capacity. There were twelve graduates, four boys and eight girls, on the rostrum. They did honor to themselves and their instructors. ... We hope many of the graduates will take the county superintendent's advice and enroll themselves in some good high school" (Columbus Republican 1895).

By 1888 there were close to 100 schools in Bartholomew County (Marshall and Prather 2003:201). Union Township had six school houses in 1874 (Cline and McHaffie 1874:346). Schools were supposed to be located so that no student would have to walk more than 2 miles. According to one Bartholomew County resident, "We never heard of school closings because of severe weather (even in that memorable winter of 1917-18). We traveled by "shank's pony." We walked with long underwear as part of our armor, topped with black ribbed stockings, and footed with high top shoes and our "Arctics" (overshoes) we survived" (Essex 1976). Schools were often named for the local families. For instance, in Nineveh Township, Bartholomew County, there was the Hog Bottom school (or Renner school for the Renner family), which "stood in the bottom land west of the Driftwood river where corn grew tall and hogs grew fat" (Essex 1976). Also the Gosch school was on the "southside" of Camp Atterbury (Gosch family), the Records school in the northeast (Records family), Kansas school, Drybread school (Drybread family), and Neville school (for Ed Neville) (Essex 1976).

In Nineveh Township, J ohnson County, there were ten school districts in the late 19th century. Calvin (No 1.) was located at the intersection of Hospital and School House roads within Camp Atterbury. It was built in 1873 and was constructed of brick (Hibbs 2007:24). That same year, a high school was built, which was the first for the township, and it is claimed to be the first rural township high school in Indiana (Hibbs 2007:26) (Figure 27). The high school was a two-story brick building. By 1906, it was too small for the number of students in the district. It was torn down and the bricks were used to construct a larger school of "eight rooms supplied with good light and hot air heat" (Franklin Democrat 1926 in Hibbs 2007:27). In 1893, Nineveh Township enrolled 177 boys and 162 females, for 115 school days; the township library had 180 books in (Bergen 1984:317). 


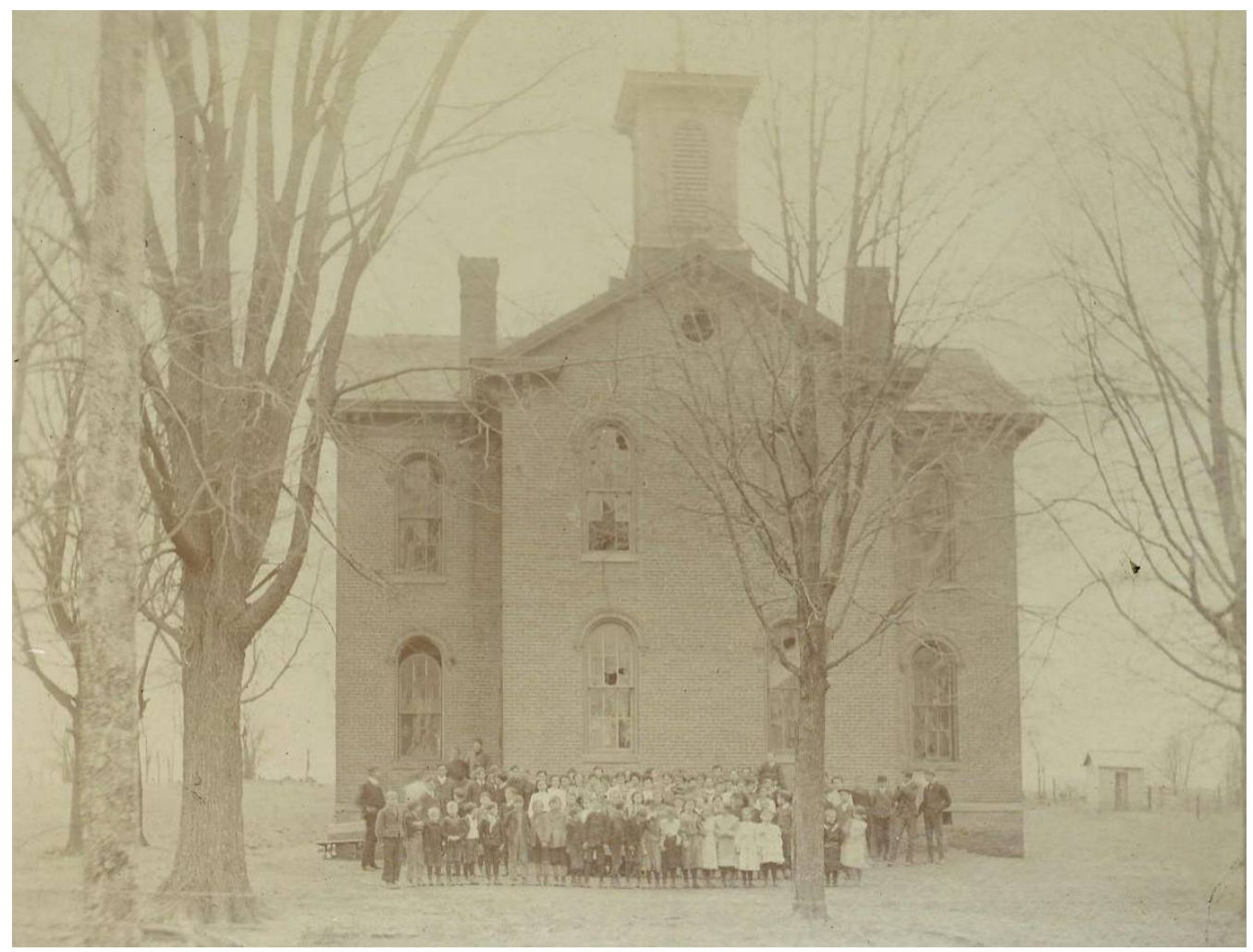

Figure 27. Nineveh High School, circa 1885 (courtesy Johnson County Historical Society, Franklin, IN).

In 1912, Nineveh Township had nine schools. Ninevah school No. 1 was the closest to Camp Atterbury with five teachers grades 1 through 8 (Franklin Democrat 1 November 1912). In 1914, a school report indicates that there were nine teachers in Nineveh Township (Education Report 1914).

Agricultural societies expanded during this period. The original Bartholomew County Agricultural Society folded in 1876, but in 1881 another society was organized and in 1883 the Bartholomew County Agricultural and Industrial Association was formed (BaCHS 1976:38). The largest agricultural society was the Grange, which organized in Indiana in 1872 and by the following year had as many as 18 units in Bartholomew County (Marshall and Prather 2003:78). In 1919, Bartholomew County farmers organized their own Farmers Association. Nineveh Township had 38 members while Union Township had 28 (Marshall and Prather 2003:80). In 1923, this organization became part of the Indiana Farm Bureau.

Secret societies also grew in influence. During the 1880s, a vigilante organization, similar to the Ku Klux Klan, began harassing and threatening citizens who did not fit their "acceptable manners and morals" (Marshall and Prather 2003:20). These regulators were called Whitecappers, and al- 
though they originated in Crawford and Harrison Counties, they had made their way into Brown and Bartholomew by the 1880s. Like the Ku Klux Klan (KKK), they attempted to assert control through threats of violence against the non conformers (Nicholson 1992:142-143). The peak of activity in eastern Brown County was around 1902 (Nicholson 1992:149). A series of trials from 1907 to 1909 helped to dissolve the Whitecappers in Bartholomew County and eastern Brown County (Marshall and Prather 2003:20).

Another type of "regulator" society that formed in the late 1870s in Brown County was detective associations. Hamblen Township had its own Horse Thief and Felony Detective Association, which was a group of citizens who arrested anyone who stole horses, pigs, or cattle. They were actually sanctioned by Indiana Law, so technically, they were not vigilantes. They acted like constables and were less likely to resort to direct violence than Whitecappers. The Hamblen group lasted until 1923 (Nicholson 1992:132-133).

During the latter half of this period, people in the tri-county region and Camp Atterbury witnessed increased social and educational opportunities. The Franklin Opera House opened and in 1894 in Columbus the public library opened (Marshall and Prather 2003:53). It would become the county library in 1923. J ohnson County historian I. George Blake wrote that:

J ohnson county was a pleasant place to live during the early part of the century. It was a period when libraries, parks and playgrounds were being established. It was a time of concerts, chautauquas, religious revivals, strawberry festivals, home talent plays at the Opera House, literary societies in the homes, lodge hall dancing, victrola music, listening-in on party lines, taffy pulls, pictures with actors moving on a screen at the Nickelo, roller skating on an indoor rink, first ride in an automobile, athletic contests, glee clubs, oratorical and declamation contests (Blake n.d. 7).

Cultural change of a different kind was occurring in Brown County. As subsistence farmers lost their lands and migrated out of the county the transformation that occurred capitalized on the natural beauty and rugged landscape of the area at the turn of the $20^{\text {th }}$ century and Brown County became a tourist destination and an artist's mecca. Famous Indiana artist T.C. Steele arrived in Brown County in 1909, followed by Gustave Baumann. Both these artists and others painted Brown County landscape scenes introducing the county to the larger world. By 1914, Nashville became known as an artist colony (Nicholson 1992:156). Photographer Frank Hohenberger began roaming the Brown County hills around 1912 and 
documented the backcountry beauty and the subsistence farmers through the 1920s (Nicholson 1992:16-161). Hohenberger later wrote newspaper columns about the county, which attracted more and more tourists to the area. Tourism and art were the future of Brown County.

\section{Transportation}

During the late $19^{\text {th }}$ and early $20^{\text {th }}$ centuries, roads improved significantly (Figures 25 and 26). The period between the 1870s and early 1880s was the era of the toll road and quite a few miles of toll roads were developed and maintained around Camp Atterbury, including the Edinburgh \& Kansas Turnpike, but toll roads came and went quickly as they were financial failures. One reason is that toll operators had difficulty collecting their tolls. The Bartholomew County Historical Society has a collection of complaint forms filed against citizens who failed to pay their toll (Figure 28). By 1885, it was clear that toll companies could not maintain the roads and the public began to clamor for better roads controlled by the county. The transition was quick in J ohnson County and by 1887 all the county's toll roads were gone (Branigin 1913:519). In Bartholomew County toll roads continued a little longer. A county vote taken in 1886 showed that most residents still opposed county take over (BaCHS 1976:28). Toll roads across Indiana continued to fail and by 1905 there were only 112 miles of private roads left in the state (Philips 1968:262).

In the late 1880s, tri-county residents saw that publicly owned gravel roads were the future. Gravel had been used for improving roads at least as early as the 1870s. The state's free gravel road system, financed by bonds, became popular throughout Indiana. In the summer, farmers would haul and lay down gravel to pay their road tax (Marshall and Prather 2003:63). One county guide pronounced that "Gravel and sand beds are numerous in many parts of the [Bartholomew] county, thereby affording the facilities for good gravel roads, which her enterprising citizens are using to good advantage" (Cline and McHaffie 1874:134). By 1880 there were around 150 miles of gravel roads in J ohnson County, and by 1913 that had increased to 276 miles (J CHS 7 April 1990; Branigin 1913:520). Gravel was an improvement, but not the panacea for reliable transportation. If it snowed or rained heavily, people still were unable to travel rapidly or at all in the rural areas. Asphalt began to be used in the $20^{\text {th }}$ century, but was adopted slowly due to costs. 


\section{STATE OF INDTANA, \}, BARTHOLONEW COUNTY, Bzrfore 15 the \\ Mror
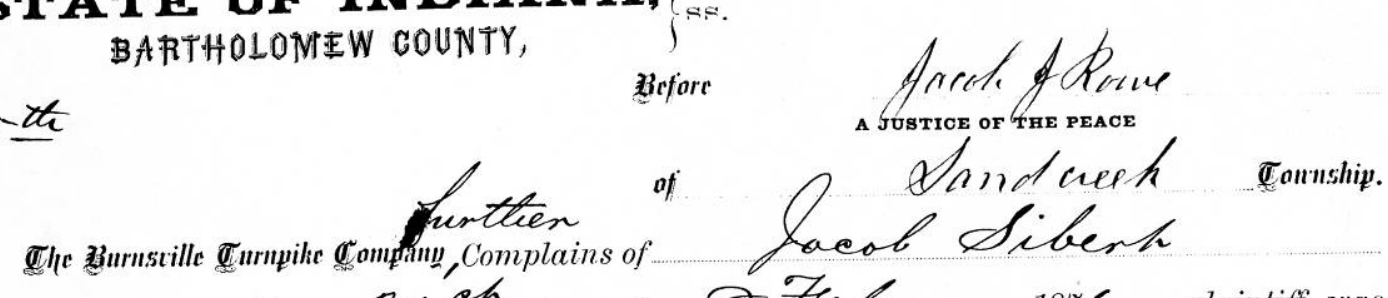 and says that on the 21 ch day of $O$ Feby, 1876 , plaintiff was the owner of a Turnpike or Gravel Road leading from a point near the city of Columbus, In- diana, where the Columbus and Hope Turnpike Road leaves the Madison and Indianapolis State Road in a northerly direction; thence from that point over and along the said Madison and Indianapolis State Road, or as near thereto as it was practicable to make it; and then had three consecutive miles of said road completed, and had erected a toll-gate and toll-house on the portion thereof completed; and the rate of toll established by plaintiff nver said road. was and is for a oue lorse velicb Tro cuto. \\ per mile; and the rates of toll were placed in full view, in legible and large letters upon said. toll-house, and said Company had an agent at said gate to collegt tolls lawtully duy frgm persons traveling upon said road, and on said day said defendam traveled, upone said road a distance of, to-wit: mules, whereby he became liable to pay, as toll therefor, to-wit: the sum of Que cents, which sair sum was then and there demanded of him by plaintiff's suid agent, but which said defendant, with the intent to defraud said Company, refused to pay, whereby an action hath accrued to plaintiff to demand and recover of and from said defendant the sum of three dollars, forfeited to plaintiff by the form of the Statute in such case made and provided, for.

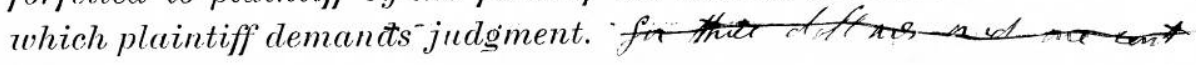

Figure 28. Complaint for non payment of Toll, Bartholomew County (courtesy Bartholomew County Historical Society, Columbus, IN).

At the turn of the 20th century, automobiles came on the scene and forever changed the landscape. The first automobile in Brown County was owned by Dr. Ray Tilton, who purchased his vehicle on 26 March 1911. By 1914, there were 15 automobiles in the county, and by 1917 there were 125 (King 1995). Automobiles were the driving force behind the cry for better roads and a state/ national system of roadways from this time forward in American history (Figure 29).

Another solution to more reliable transportation was the construction of iron bridges to replace the ferries. This began in the 1870 s. In 1873, for instance, iron bridges were built over Sugar Creek near Smiley's Mill and across that same creek along the road between Edinburgh and Nineveh (Hibbs 2007:29). The transition was slow and ferries still operated until the 1930s. 


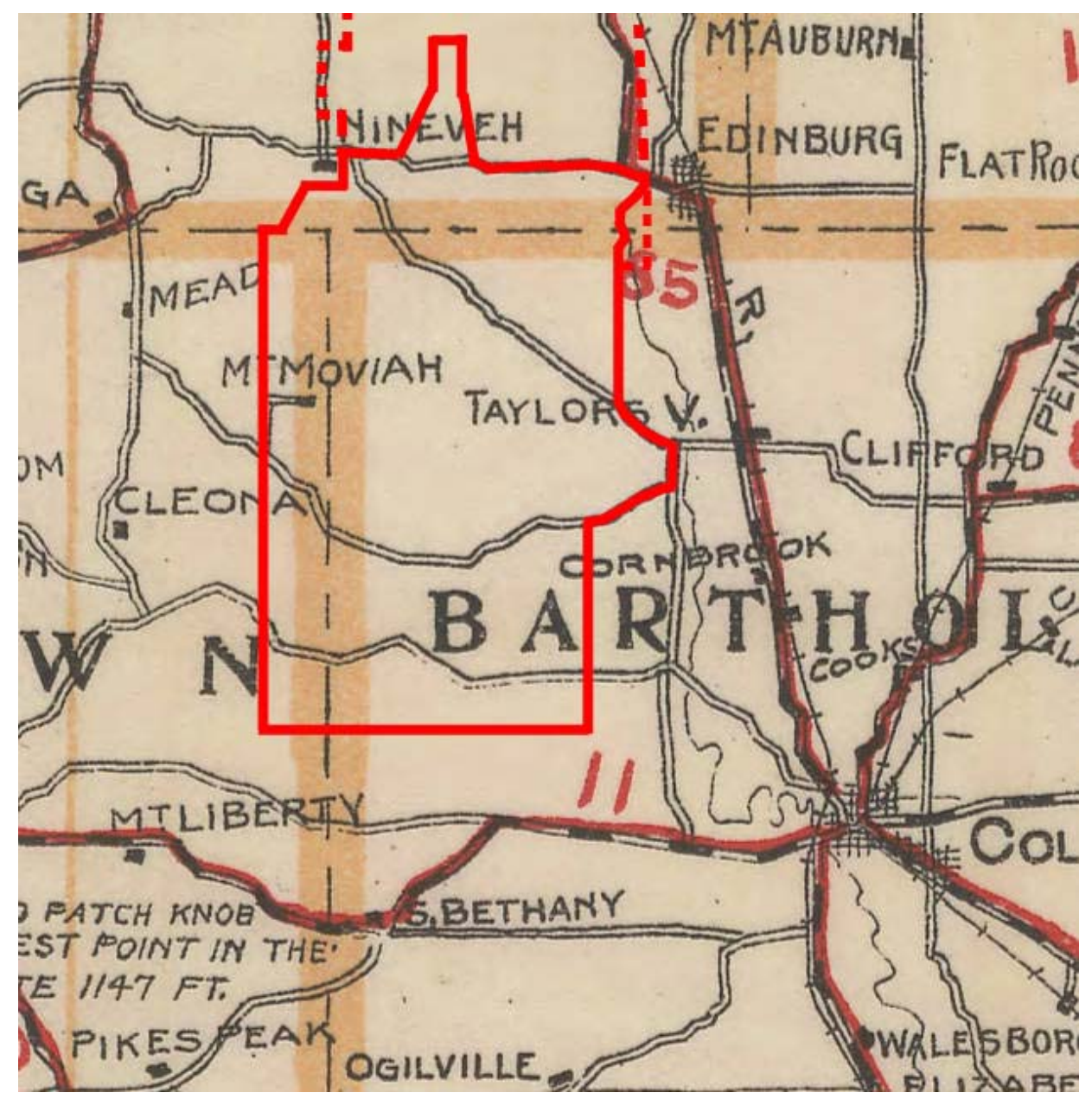

Figure 29. Enlargement of 1906 Mendelhall's Guide and Road Map of Indiana (courtesy IUPUI Digital Library Collection, on-line).

Delivering goods to market was one of the forces behind the call for road improvement, which meant that the best roads, or the roads improved first, were those leading to the railroad. The railroads was the "king of freight" after the Civil War. By 1880 the Towns of Franklin, Edinburgh, and Taylorsville located along the rail line from Indianapolis south to Columbus were vital transportation nodes for the Camp Atterbury farmers. At that time, the railroad still branched at Columbus southeast to Madison or directly south to J effersonville. It was called the J effersonville, Madison, and Indianapolis Line. There was another branch from Columbus northeast to Shelbyville and Greenville (Thornbrough 1965:351; BaHS 1976:30). North of Camp Atterbury there was another line running southeast from Franklin to Martinsville called the Fairland, Franklin, and Martinsville (Thornbrough 1965:351). There was no rail line in Brown County. Thus Camp Atterbury market goods traveled east to Edinburgh, Taylorsville, and Columbus for processing or shipment to national markets. 
These railroads did much more than provide a market source. They also opened Camp Atterbury to the world at large. At the turn of the century, residents of Camp Atterbury found themselves able to get to Indianapolis and perhaps home again in the same day when the interurban train arrived at Edinburgh. The first interurban train, using the rail beds of the railroads, rolled from Franklin to Indianapolis in 1901. The following year, Camp Atterbury residents could ride the Interurban between Indianapolis and Edinburgh (Branigin 19193:522). In 1903, the line was extended south to Columbus (Otto 1987:49). The year 1913 is remembered as the year of the flood, when 9 in. of rain fell in 24 hours on 27 March. The flood damaged Thompson's Mill, flooded part of Edinburgh and washed out the interurban line cutting communication and transport between Edinburgh and Franklin (Otto 1987:55).

Improved roads and passenger service to Indianapolis and J effersonville all worked to break the rural isolation of Camp Atterbury. This period saw not only technological advancement in transportation, but also in communication. In 1882, a telegraph line was constructed down the state road from Indianapolis to Madison, and in the same year telephones were introduced to the area. By 1897, the town of Franklin was well connected by telephone and in 1913 J ohnson County had 2900 telephones in operation (Branigin 1913:522). There is no evidence that the Camp Atterbury region had telephone service at that time. Most of those who had telephones lived along the transportation corridor between Franklin, Edinburgh, Columbus, and Indianapolis (Branigin 1913:522).

Perhaps the most significant advancement that connected Camp Atterbury to the larger world was Rural Free Delivery. This began as early as October 1896 in Indiana. It is unknown exactly when Rural Free Delivery began in Camp Atterbury, but it was available by 1900 (Philips 1968:141). Rural Free Delivery assisted farmers with personal mail and also brought new agricultural magazines from the agricultural schools like Purdue University, and similar new ideas for women in homemaking. Sears and other company product catalogs introduced the Camp Atterbury residents to new products to make farming and house work more efficient. Through Rural Free Delivery, products and information arrived on the doorstep instead of requiring a trip to Edinburgh, Taylorsville, or Columbus. 


\section{Industries}

Camp Atterbury remained a rural farming region with little industry in the late $19^{\text {th }}$ century. This reflected general trends in Indiana where over half the people were engaged in agriculture and 80 percent were classified as rural during this period (Thornbrough 1965:363). However, in Columbus, Edinburgh, and Franklin industries grew that improved the lives and fortunes of Camp Atterbury's farmers. The 1870 census provides a snapshot of how far the tri-state region had come in development of businesses and industries. In J ohnson County, there were 11 brick kilns, 13 wagonmakers, 11 flour mills, 14 saw mills and two planing mills, eight harness shops, a starch mill, two woolen mills, and seven cooperages (U.S. Census 1870). Bartholomew County had five agricultural implement shops, 13 brick kilns, 13 flour mills, 12 saw mills, nine harness shops, five cooperages, and two canneries (U.S. Census 1870).

Brown County remained without any industry except seven sawmills and four leather shops (probably tanneries) (U.S. Census 1870); one of these leather shops was J ames C. Parmerlee's tannery in Hamblen Township. The tannery began operation around 1826, and continued throughout this period, winning state, national, and international awards according to an 1876 historical atlas of Indiana (Bailey 1976:45). J ames died in 1872, but the tannery continued until 1879. In J ohnson County, the W.W. Mooney \& Sons tannery, first opened in Nineveh in 1837, moved to Columbus in 1863 (BaCHS 1976:160).

Grain and lumber mills were still the largest industries through this period. In 1865, a flour mill opened in Columbus that was quickly changed to hominy. During an accident or an experiment, the rollers for making hominy were placed close together and out came a flaky corn product, which was sold to breweries. In 1884, the new product came on the market as Cerealine breakfast food. The Cerealine Company moved to Indianapolis in 1892, but Camp Atterbury farmers probably sold a lot of their corn to this company (BaCHS 1976:159). Columbus had other mills including Donner Mills and Schaefer Mills, and a Taylorsville mill that moved to Columbus in 1874 operated by J .R. Gent \& Company. Many of these mills changed owners and locations in Columbus, but served the Camp Atterbury region (Marshall and Prather 2003:102-103).

There were also mills closer to Camp Atterbury that served the community. Within Atterbury, along Sugar Creek, was Foster Mill. In 1875, it became the Furnas Mill, named for Orlando Furnas. It continued to prosper 
through the late $19^{\text {th }}$ century (Figure 30). At the turn of the century it was considered a historic monument, but was still being used by J ohn Workman to grind custom corn. On 31 J uly 1913, it was struck by lightning and burned completely (Franklin Democrat, 8 August 1913). Collier's Mill downstream and within Camp Atterbury operated until around 1876, but was a ruin by 1881 (Smith 1987). Little is known about its operations.

The Thompson Mill on Blue River was another landmark during this period. Originally, the mill was jointly built and run by J ames Thompson and his father-in-law Isaac Collier and was also called the Thompson-Collier mill. Back in 1850 a large four story brick mill replaced the original mill, but in 1872 the brick mill burned. J ohn Thompson replaced that mill with a six story brick and stone mill (Black n.d.:34). The mill's production peak was in the 1870s. In 1884, a stone dam was constructed to control the flow of water and is still visible today in Irwin Park, Edinburgh. In 1886, J ohn died. His sons took over the mill and ran it until 1890s when the family bank failed. Afterward, several entrepreneurs attempted to manufacture corn meal at the mill. At one time the city of Edinburgh tried to use the power mechanism to produce electricity. That failed, but during WWI, generators were added and used to power the Union Starch and Refining Company. The last owners were the Irwin's who moved to Illinois in 1922 (Otto 1987:16-17).

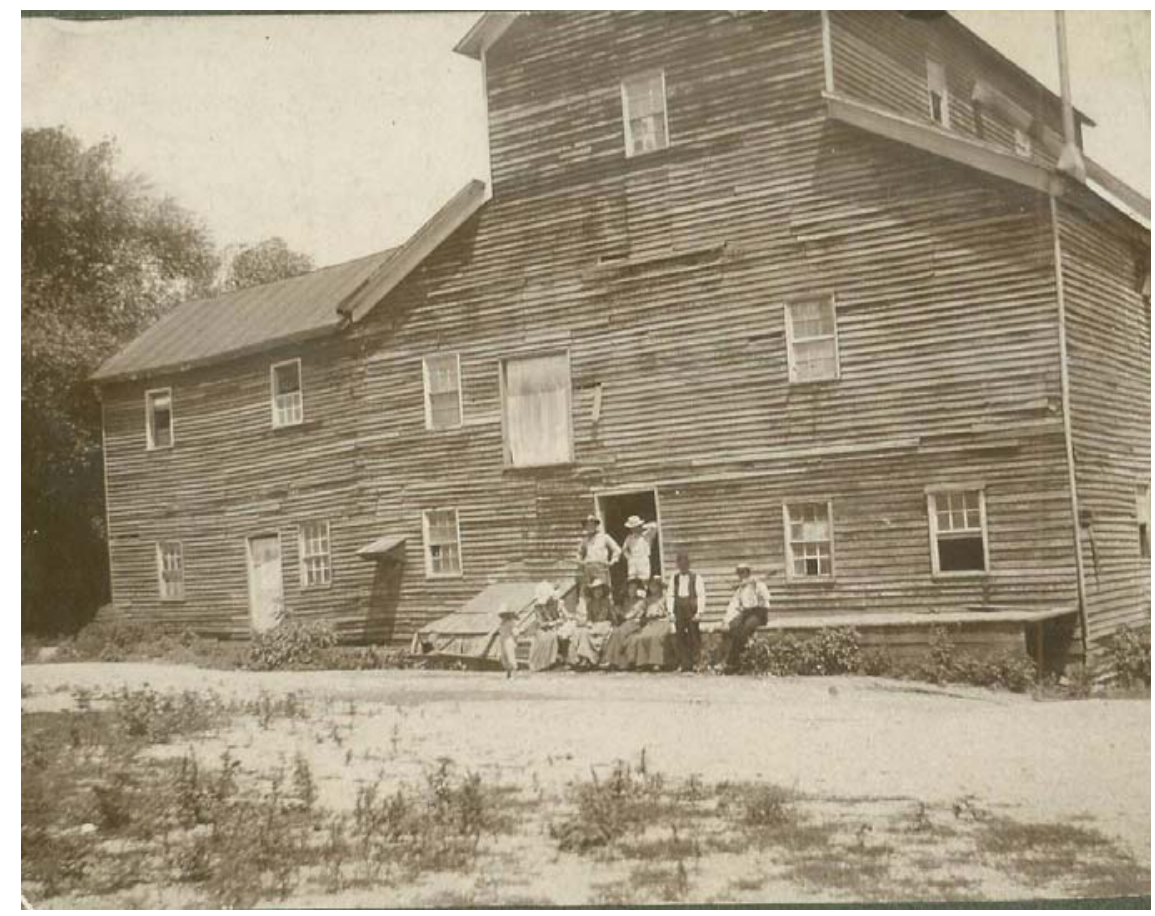

Figure 30. Furnas Mill at Sugar Creek, Blue River Township, Johnson County (courtesy Johnson County Historical Society, Franklin, IN). 
Another important mill for the farmers of Camp Atterbury was the mill at Lowell along the Driftwood, near Taylorsville. Built on the site of a previous mill (see Chapter 2 [p 11]), "Lowell Mills" prospered through the late $19^{\text {th }}$ century. In 1879, it ground some 91,532 bushels of wheat (BaCHS 1976:206). Nearby was the Tannehill-Drybread Mill. A woolen mill at first, it was converted into a flour and feed mill in the late 1870s and changed owners several times (BaCHS 1976:219). In 1895, it was under the ownership of Seneca Drybread and called the Valley Roller Mills consisting of a large three story building that produced two grades of flour, corn meal, and crushed feed. It had the distinction of being the "only one in the county the power for which is furnished by water, but it 'grinds and grinds' just the same" (Columbus Republic 1895).

With the abundant corn and wheat produced in the area, it was natural that starch became an important regional agricultural product. Starch works began in the 1860s. In 1880, two large starch works were established, one in Franklin called the Franklin Starch Works of Thompson, White \& Company (Banta 1888:512) and the other in Columbus called the American Starch Company (BaCHS 1976:160). Another was the Indiana Starch Company also in Franklin (Banta 1888:513). In Edinburgh the Blue River Starch Factory was established in the 1880s (Banta 1888:538). The Blue River factory produced pure corn starch, refined pearl and powdered table corn starch, and white gloss lump starches. It produced 7.5 million pounds of starch annually (Otto 1987:31).

\section{Logging}

The most dramatic impact to the Camp Atterbury landscape occurred during the late $19^{\text {th }}$ century. At the beginning of this period, Indiana was still a forested landscape. U.S. Department of Agriculture noted that in the mid 1870s, Indiana was still 40 percent timber covered (Philips 1968:213), but:

Most of the state's forests were cut during the period from 1870 to 1900 , when large tracts of wooded land were converted to fields for agricultural crops. This conversion was hastened by the advent of the steam-powered sawmill which made it possible to meet the high demand for wood products in the decades after the Civil War. (Philips 19678:213)

Brown County would suffer the most, along with the central and southern portions of Camp Atterbury. There were numerous saw mills in the tricounty region in 1870, and these mills continued operation through the late $19^{\text {th }}$ century. In 1880, J ohnson County had 20 saw mills, Bartholomew 
had 24, and Brown County had seven (U.S. Census 1880). One of these was the Taggart Mill in Hamblen Township, Brown County, near Camp Atterbury. It was established around 1879 and in 1880 William Taggart added a grist mill (Bailey 1991:48). The lumber mill employed six people, cutting some 100,000 board feet annually (Nicholson1992:124).

Like many areas of the South, the logging was done by lumber barons. In Brown County, a man named J ohn McGregor arrived in 1879 and immediately began to purchase large tracts of land. Over the next 10 years, he purchased over 7000 acres and obtained logging rights to more. By 1880, McGregor, the Stave King, employed some 200 workers at his mill and shipped six million barrel staves and 2 million board feet of lumber out of Brown County forests (Nicholson1992:106-107). McGregor's offices were in Columbus, so both Brown County and Bartholomew County saw an economic boost from the business. McGregor was popular in the community for he hired local farmers during the winter months. By 1888 they were shipping 85 railcar loads of staves from Columbus every quarter of the year (BaCHS 1976:161).

While McGregor was the largest stave producer, his success encouraged others and even more timber was cut. As mentioned, this included the Taggart family in Hamblen Township. However, once the timber in Brown County was exhausted around 1887, McGregor left with much of the county landscape cleared of timber. At first the lands were somewhat fertile, but after the trees were removed, the hillsides quickly eroded. Some lumbering continued in Brown County until the 20 th century, smaller trees were cut for railroad cross ties or for tanning. Cordwood also continued to be cut as a source of income well into the $20^{\text {th }}$ century (Mathis 1936:45). However, by 1910, the lumber industry in Indiana was importing trees from out of state to operate its mills (U.S. Census of Manufacturers 1910:303).

\section{Business and trades}

A guide to Bartholomew County published in 1874 provides a snapshot of the professional community in Camp Atterbury (Cline and McHaffie 1874). Most people were farmers and numerous people were both farmers and professionals in another area. Union Township had a blacksmith, one farmer-blacksmith, one saw miller-farmer, one wagon maker-farmer, one saddler-farmer, three carpenter-farmers, two tanner-farmers, two day laborers, one thresher-farmer, two farmer-machinists, one farmer-stone cutter, three farmer-shoemakers, one farmer and manufacturer of Calhoun 
plow handles, two carpenters, one physician-farmer, three farmer-shingle makers, one farmer-merchant, one school teacher, two school teacherfarmers, one wagon maker, two coopers, and two farmer-coopers. Nineveh Township had one engineer at a saw mill, one farmer-tile maker, two teamsters, four persons in saw milling, two blacksmiths, one farmerschool teacher, two carpenters, one laborer, one school teacher, one farmer-township trustee, one farmer-stock raiser, and one shoemaker (in Kansas). Note that there were many fewer men listed as being both farmers with an additional profession in Nineveh Township. This may have been because Nineveh had better farmland or it might have been caused by the differences between interviewers' questions.

\section{Towns}

After the Civil War and into the $20^{\text {th }}$ century, Columbus, increasingly became the primary central location for obtaining supplies, equipment, and medical assistance needed by the families living in the Camp Atterbury region. It was the main market for Camp Atterbury agricultural products. A detailed history of the town is beyond the scope of this study, but it must be noted that Columbus was the source of economic life for Camp Atterbury. Columbus had grain and saw mills, elevators, dairies, farm equipment stores, slaughter houses and meat packers, canneries, groceries, and department stores.

Through the late $19^{\text {th }}$ and early $20^{\text {th }}$ centuries many small towns grew and new ones sprang up, often as a result of the need for a railroad stop or post office. Taylorsville, originally a rail stop, was incorporated in 1876. By the 1890s it had mills, two hundred residents, a barber shop, two blacksmiths, a wagon maker, physicians, general stores, drug store, and a hotel (Columbus Republican 1895; BaCHS 2003:138). A grain elevator was built in 1915.

Kansas, one of two hamlets fully within Camp Atterbury never commanded much respect among historians. The original history of Bartholomew County published in 1888 described it as being "of no commercial importance” with about 200 inhabitants (BaCHS 1976:177). There was only one store, which was operated by J efferson Huffman. There was also a saw mill owned by Frank Emmons, which was the only business. By 1904 it had a wagon maker, blacksmith, and painter and perhaps reached its developmental peak. The 2003 history of the county noted that "Kansas, never much more than a sharp turn in the road, consisted of five or six houses, a small store with a gasoline pump out by the road, a blacksmith 
shop, Kansas Christian Church, Nineveh Methodist Church, and the Kansas school a short distance away" (Marshall and Prather 2003:151). People often said that no one could go through Kansas, "because it was all on one side of the road" (Essex 1976).

Mt. Moriah in Brown County was the other hamlet within Camp Atterbury at this time. In the 1880s, it had a post office that closed in 1905 when its mail service moved to Columbus (Baker 1976:987; see Figure 31). Still, it had 100 residents in the 1880s, including three blacksmiths, a saw mill, shoemaker, general store, and physician (Polk Directory, 1882). The residents of Mt. Moriah and those in Brown County along the western side of Camp Atterbury area conducted their banking, shipping, and shopping in Edinburgh, Taylorsville, and Columbus.

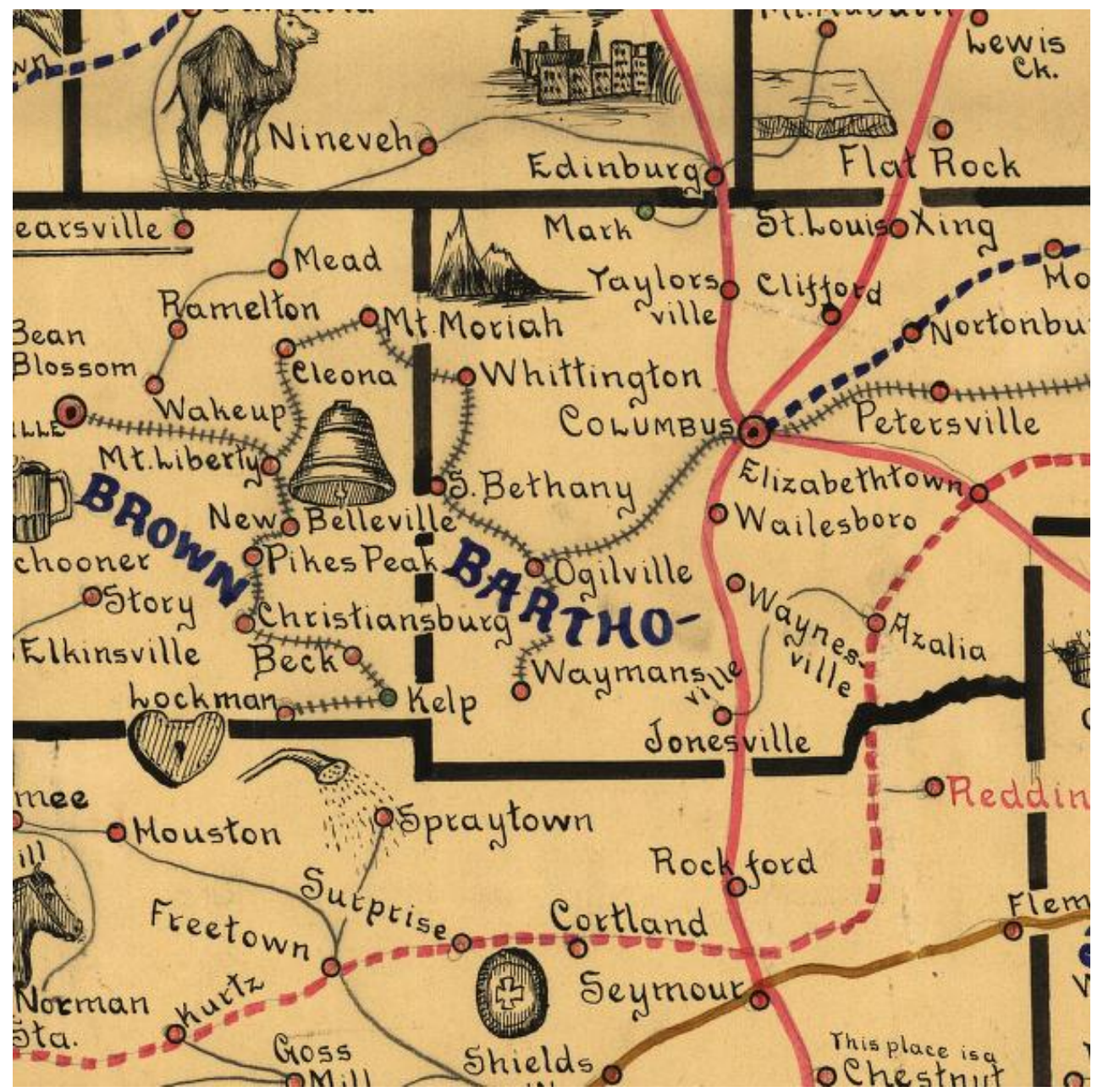

Figure 31. Enlargement of Galbraith's Railway Mail Service Map of 1897 (courtesy Library of Congress American Memory Collection, on-line) 
By the late 19th century, Edinburgh had grown to a substantial village and became an important market center for the Camp Atterbury region. It was located between the two county seats of Franklin and Columbus, and along the main north to south road and rail network. Historian D. D. Banta described it in 1888: "Occupying, as it does, a beautiful site on the bank of Blue River, and encompassed by a flourishing agricultural region, it seems to have obtained the kindest favors of fortune" (Banta 1888:527).

The town flourished after river obstructions were cleared from the Blue River and the railroad was built. By 1871 it had several industries, including a mill that produced hominy, and a starch mill, a flour mill, and a woolen mill. It also had a planing mill established around 1878 (Banta 1888:536). Right at the publication of Banta's 1888 history, the town also had a Pump factory, pulley factory, and starch factory. In 1875, the Edinburgh Courier began printing local news for residents of Edinburgh and Camp Atterbury (Banta 1888:542). It is clear that during the late $19^{\text {th }}$ and early $20^{\text {th }}$ century, Edinburgh, even more so than Franklin, was the pride of the county and a cosmopolitan community. In 1913, it was the only town in the county that had its own water works and electric light plant, which was established as early as 1897. It also had a first rate school system and telephone system (Branigin 1913:530). The town had all of the usual business enterprises, and also some unusual ones for the time: an automobile garage, three bakeries, a coal company, a florist, four insurance companies, a nickelo (probably nickelodeon), and three veterinarians (Branigin 1913:541).

In 1880, the village of Williamsburg (Nineveh) had a population of 200 (Figure 32). There were three blacksmiths, a grocery, two shoemakers, a general store, a dry goods store, two carpenters, a flour and saw mill, a harness shop, two physicians, another physician and druggist, and a wagonmaker (Bergen 1984:255). By 1888 the village had grown to 350 inhabitants, and new businesses included a combined grocery and hardware store, two drug stores, a confectionary, a harness-maker, a shoemaker, a livery stable, an undertaker, and a sale stable (Banta 1888:560).

In 1894, the village was still growing with 425 inhabitants and new business included a livery, four persons in livestock, a fence manufacturer, and a furniture store (Bergen 1984:255). By 1913, it was clear that the town had waned a bit with three groceries, a hardware store and a livery being the only businesses listed (Branigin 1913:543). 


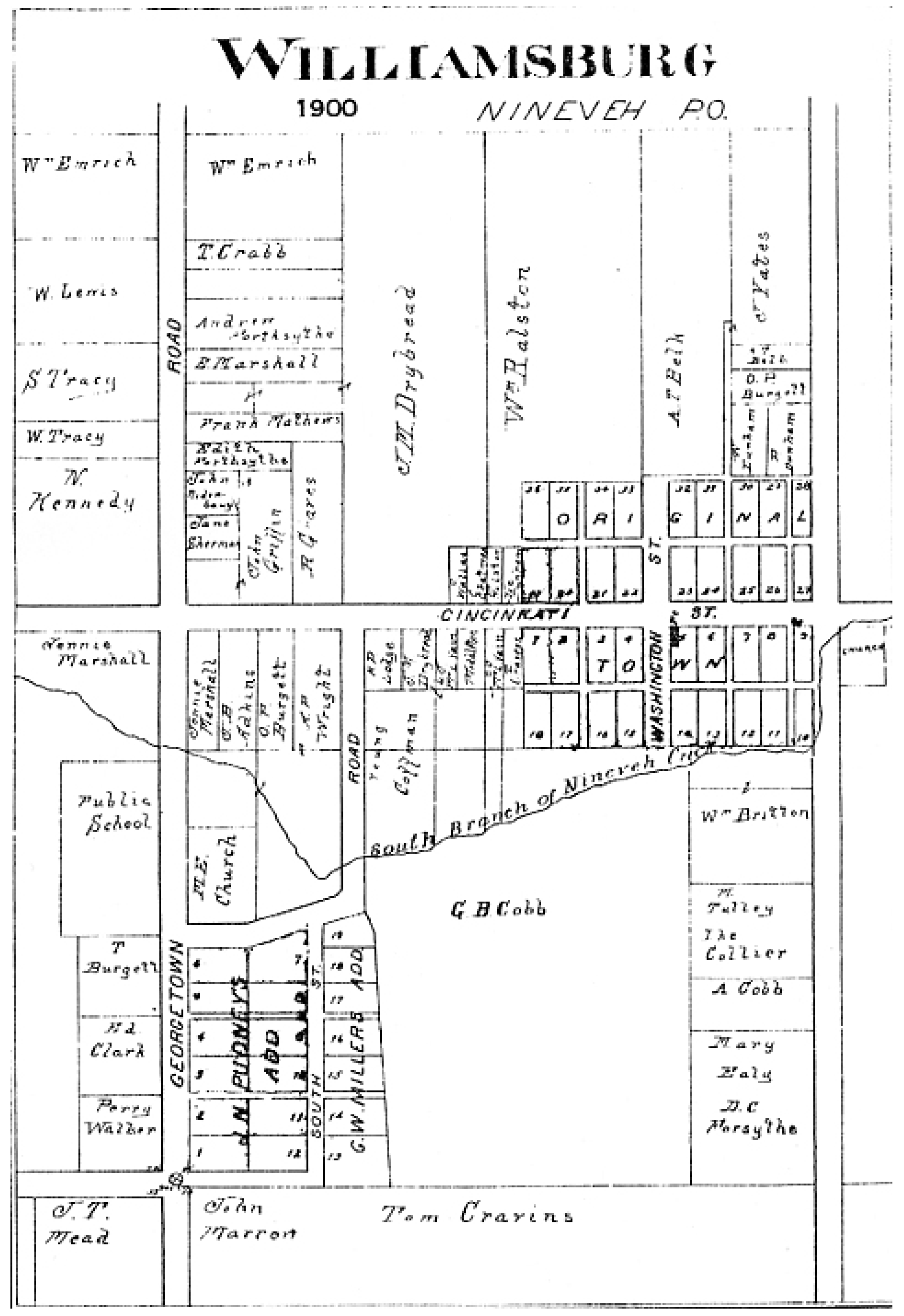

Figure 32. Williamsburg -Nineveh, 1900 (courtesy Atlas of Johnson County). 
Exactly when Williamsburg began to be commonly called Nineveh is unknown. As noted in the previous chapter, the post office was called Ninavah (with an a) in 1839. It appears that the post office was called Nineveh after that time, while the town was Williamsburg up to circa 1900, when it came to be called Nineveh in association with the post office (Bergen 1984:255).

There were other communities, which never appear to have been consolidated or large enough to be considered hamlets or villages, but were still clusters of homes with place names. One of these already has been mentioned; the Hog Bottom area. Another was the Ohio Ridge, named as a result of a group of pioneers from Steubenville, Ohio who settled there. Finally there is Whittington, which was a post stop, and it may actually have been part of the Ohio Ridge community. A mail service map of 1897 indicates its location. The map also reinforces that there was a road running out of Columbus to Whittington and then to Mt. Moriah through Camp Atterbury that is no longer extant (or perhaps the current Ohio Ridge road is a remnant of this old road). In any case, the road and Whittington disappear from most maps by the $20^{\text {th }}$ century.

In J ohnson County, historical sources mention a place called Pisgah, approximately a mile west of the Furnas Mill at the intersection of a northsouth road and an east-west road, in Section 19, Township 11 North, Range 5 East, just inside the Camp Atterbury boundary. This location is the site of the Pisgah School (No.4), Pisgah Christian and Pisgah M.E. church and no doubt the community became recognized as a result of the church. It is not known how long the Pisgah community was in existence, but a map indicates that the churches were active in 1880 (Bergen 1984:257). The vicinity of Furnas Mill included a few homesteads and was called Harvest City (Bergen 1984:257; Blake n.d.120).

\section{Summary of the late $19^{\text {th }}$ century landscape}

A guide to the county, no doubt intending to encourage settlement was positive. Nevertheless, it sets the tone of the times and the landscape of the late $19^{\text {th }}$ century in and around the Camp Atterbury. Describing Bartholomew County in 1874, it embellishes that:

Her wealth and improvements have steadily increased rather in advance of her population. Fine dwellings and farms, fine churches and school houses, fine grist mills and manufacturing establishments, and fine towns and villages have sprung up all over the country as indications of 
wealth and prosperity, while rude log structures used for churches and school houses, the old-fashioned horse mill and the fur trader have long since gone where the woodbine twineth.

She now has her principal thoroughfares graveled, and about 40 miles of railroad, whereby travel and communication are made easy and speedy, and has a market at home for all the surplus of the county. She has several lines of telegraph, and if need be communication may be sent to any part of the world and returned with lightening speed (Cline and McHaffie 1874:137).

By 1920, the landscape within Camp Atterbury had changed from a forest frontier of dispersed homesteads with maybe one or two outbuildings, linked by muddy rutty trails, to large cleared areas revealing two-story brick or frame homes, with multiple outbuildings and large two-story barns, connected by gravel and dirt country roads (Figure 33). A few farms, near Edinburgh, even had gas or electric service. Along the roads, the rail fencing was deteriorating and at many farms was by barbed wire. At right-angle section corners the occasional church and school complex was found consisting of one room frame buildings and perhaps a store. Farm fields were dotted with mechanical devices for planting and threshing. A few of the large farms had steam driven tractors parked beside one of their outbuildings.

The landscape in the hills section of the Camp Atterbury was probably a bit different (Figure 34). Still wooded, the farms largely resembled the pioneer period. Homesteads were smaller and were of wood frame with fewer outbuildings. There were also denuded hillsides and tops where trees had been clear cut leaving deep run-offs where the topsoil had eroded. However, most farmers, even those in the hilly sections, were finding a market for their crops and if not generally prospering, at the least self sufficient. 


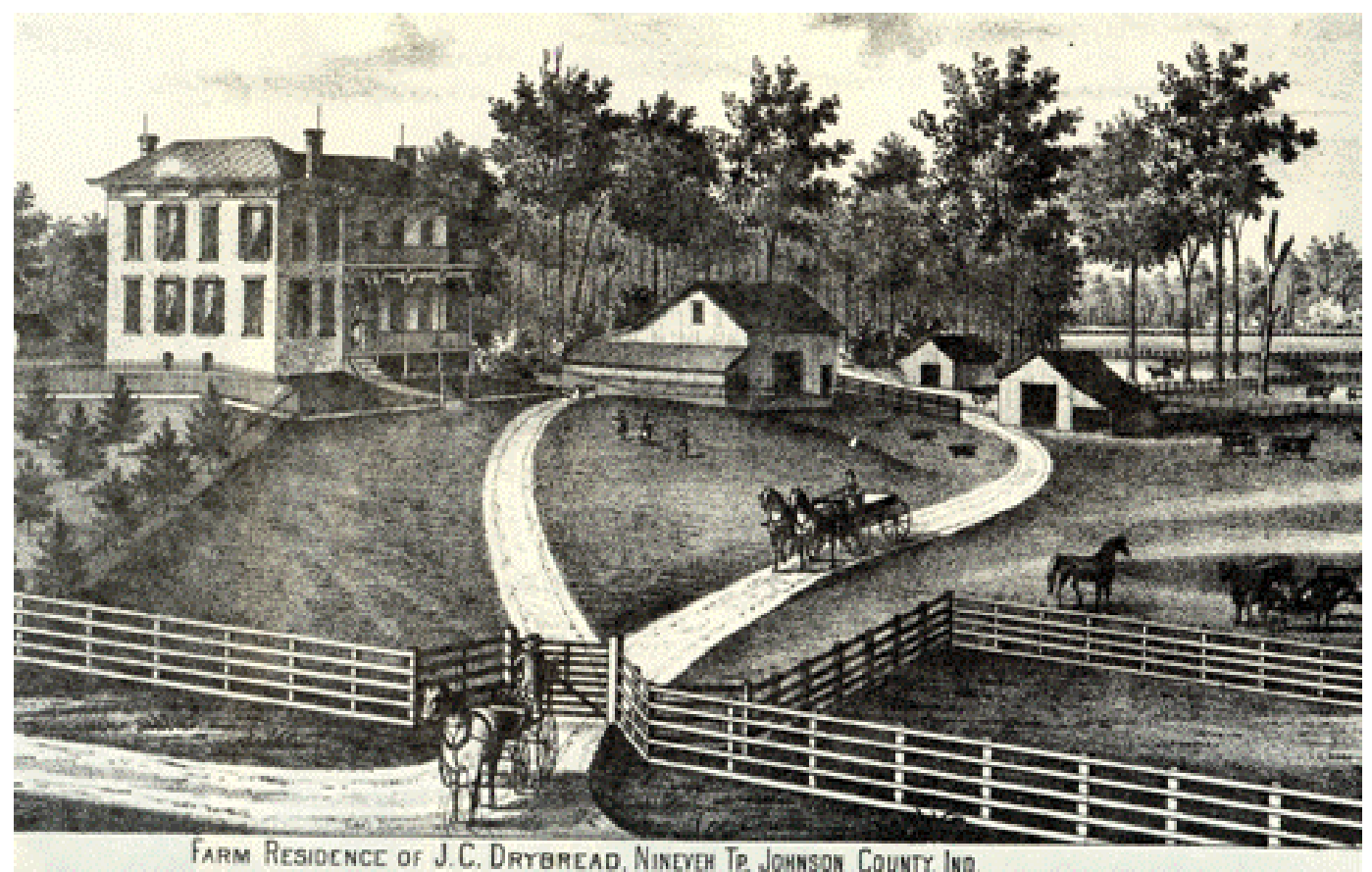

Figure 33. The Drybread farm in late 19th century, an example of a prosperous farmer of the Tipton Plain in Johnson County and within Camp Atterbury (courtesy Atlas of Johnson County).

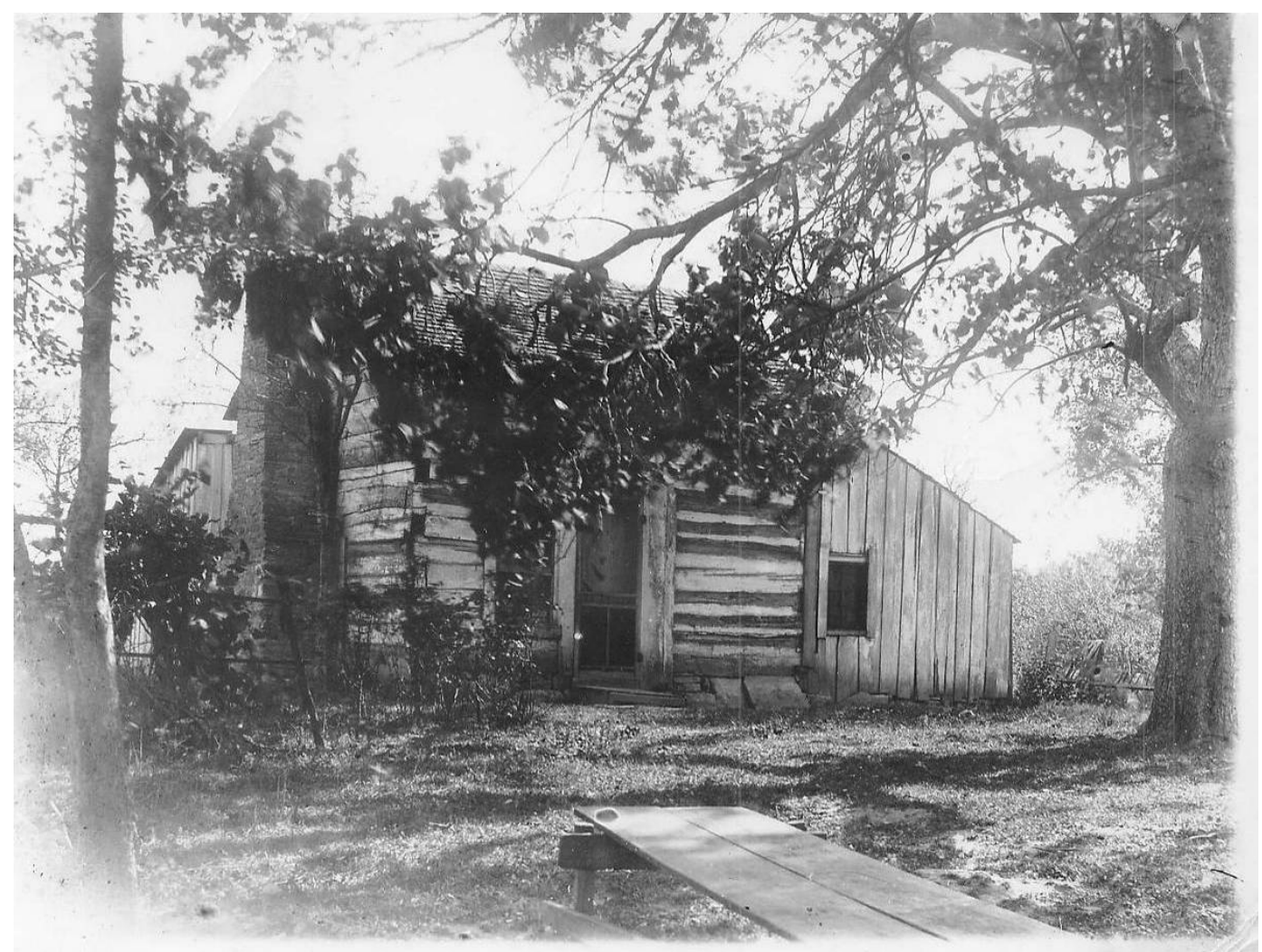

Figure 34. The Joshua Richardson cabin. Although located near Hensley (Trafalgar) in Johnson County, it is thought to be representative of the home 'steads in the hills section of Camp Atterbury (courtesy Johnson County historical Society). 


\section{The 20th Century Landscape: 1920 to 1940}

\section{Introduction}

The 1920s began well for the residents of Camp Atterbury. Crop prices were high. New land was cleared to increase yields. There were technological advances in agriculture, the most significant of which was the automobile and gasoline-powered farm equipment. Residents of towns like Columbus, Franklin, Edinburgh and Taylorsville had telephones, indoor plumbing, refrigerators, and central heating. Most of these did not reach Camp Atterbury until the 1930s. Unfortunately, farm prices dropped through the 1920s and there was a national economic Depression in the 1930s. Eventually war came to the community in the form of government land acquisition. With each of the above changes, the landscape also changed. The war's impact to the landscape was clear and extreme, the impact of the Depression much less clear. Undoubtedly, the people experienced hardships, but the residents were overwhelmingly self sufficient farmers. Although they may have not prospered, evidence suggests that they experienced less adversity than those in the cities.

\section{$20^{\text {th }}$ century population and settlement}

The census data for the period between 1920 and 1940 indicate a population drop from the late $19^{\text {th }}$ century, but a relatively stable population density throughout the first half of the $20^{\text {th }}$. The 1930 census does indicate a dip in population. This drop is probably the continuation of a trend of migration to the cities by young rural people looking for jobs. This outmigration actually began in the late $19^{\text {th }}$ century for the Camp Atterbury region (see previous chapter). The national economy also influenced this population drop. Many family farms across Indiana were abandoned in the late 1920s due to falling crop prices. However, during the Depression of the 1930s, as unemployment rose in the cities, the trend reversed and people moved back to the family farms. There was a "back to the land movement," of urban people reoccupying abandoned farms to survive on home grown crops during the weak economy (Madison 1982:167). Brown County became a popular sanctuary for these people. 
Table 18. Population for Camp Atterbury Townships, 1920 through 1940. Black population in parentheses.

\begin{tabular}{|l|l|c|c|c|}
\hline County & Township & 1920 Census & 1930 Census & 1940 Census \\
\hline Bartholomew & & $23,887(229)$ & $24,864(191)$ & $28,276(181)$ \\
\hline Bartholomew & Nineveh & 529 & 450 & $465(6)$ \\
\hline Bartholomew & Union & 445 & 394 & $522(4)$ \\
\hline Johnson & & $20,739(402)$ & $21,706(311)$ & $22,493(294)$ \\
\hline Johnson & Nineveh & 1,187 & 1,128 & 1,092 \\
\hline Johnson & Blue River & 3,088 & 2,930 & 3,065 \\
\hline Brown & & $7,019(1)$ & 5,168 & $6,189(6)$ \\
\hline Brown & Hamblen & 1,331 & 932 & 1,184 \\
\hline
\end{tabular}

Census figures demonstrate that the tri-county area was less densely populated in the first half of the $20^{\text {th }}$ century in comparison to the late $19^{\text {th }}$ century (Table 18). As seen in the previous chapter, Hamblen Township had the largest population of the townships that now include Camp Atterbury. The 1920 census records the greatest number of people within the four townships that make up Camp Atterbury. These townships are: (1) Nineveh, Township, Bartholomew, County; (2) Nineveh Township, Johnson County; (3) Union Township, Bartholomew, County; and (4) Hamblen Township, Brown County. (Blue River Township is excluded from this analysis.)

Assuming an average density per section spread over these four townships (or per square mile), and dividing the population into the area, the following township population densities were calculated for 1920: (1) Hamblen Township, Brown County, 21 persons per square mile, (2) Nineveh, Township, J ohnson County, 33 persons per square mile, (3) Nineveh Township, Bartholomew County, 22 persons per square mile, and (4) Union Township, Bartholomew County, 18.5 persons per square mile. If the average density for the four townships in 1920 was 23.6, there were fewer than 1204 persons living in Camp Atterbury at that time (Camp Atterbury =51 square miles). More accurately, Nineveh and Union Townships in Bartholomew County best represent the majority of Camp Atterbury, and the average for 1920 is therefore approximately 20 persons per square mile, or an average of 1020 persons. This is considerably less than in 1870 when there was on average 28 persons per square mile and an average of 1428 persons (see previous chapter).

The only densely populated area of the Camp Atterbury may have been near the town of Edinburgh, or in Blue River Township, where the population totals were around 3000 persons for the three censuses. However, 
most of this was probably the town of Edinburgh itself, and it is doubtful there was much of a suburb at that time. Therefore the rural areas of Blue River probably had a similar population density to Nineveh Township in J ohnson County. These population data indicate that the entire Camp Atterbury remained a dispersed farming community throughout the first half of the $20^{\text {th }}$ century (Figures 35, 36, 37, 38 and 39). This is directly supported by the census data for agriculture.

\section{$20^{\text {th }}$ century agricultural life}

Camp Atterbury remained predominately farmland throughout the first half of the $20^{\text {th }}$ century, with the only exceptions being the hamlet of Kansas and the village of Nineveh, just outside of Camp Atterbury. A common thread for Indiana agriculture and most certainly for Camp Atterbury was the persistent importance of corn and hogs during this period.

There is one generalization about Indiana farming that continued to hold through the interwar years: corn and hogs were the economic mainstay of most Hoosier farmers, as they had been since the pioneer period ... In a sense, corn and hogs were even more important than their first-and second-place individual ranks would indicate: since most of the corn was fed to hogs, the two eventually became one. (Madison 1982:153).

Bartholomew County continued as one of the state's top corn producing counties through this period. In fact, the county won the state's corn contest and was named Indiana Corn King from 1922 through 1928 (Marshall and Prather 2003:65).

Tables 19 and 20 list county level data for the tri-county region. What is clearly evident is that, like much of Indiana, corn and hogs remained the two dominate market commodities produced in the tri-county region and most likely the Camp Atterbury region, even with a downturn in overall production. Corn production took a slight downturn in Bartholomew County around the 1930s, but remained steady in J ohnson County. Swine production declined throughout the period, but still remained strong. Sheep actually increased in the 1930s and the production of wool increased from 1920 s to 1940 s. Cattle, overall, remained steady with an increase in J ohnson County in 1940 (Figure 40). It is interesting to note the amount of tobacco grown in the tri-county was greater than that used for home consumption. 


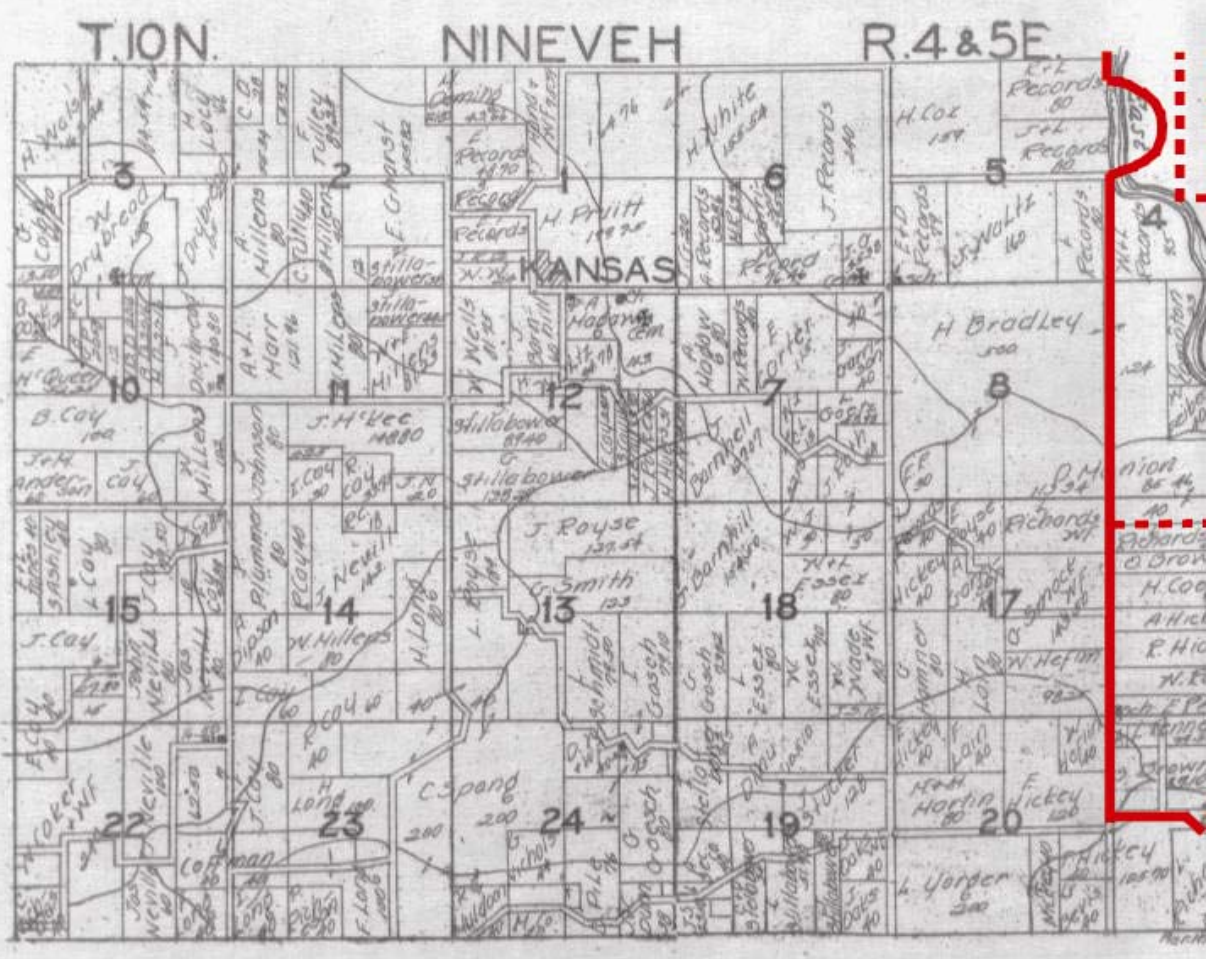

Figure 35. Nineveh Township, Bartholomew County Plat Map, circa 1925 to 1941 (courtesy IUPUI Digital Map Collections on-line).

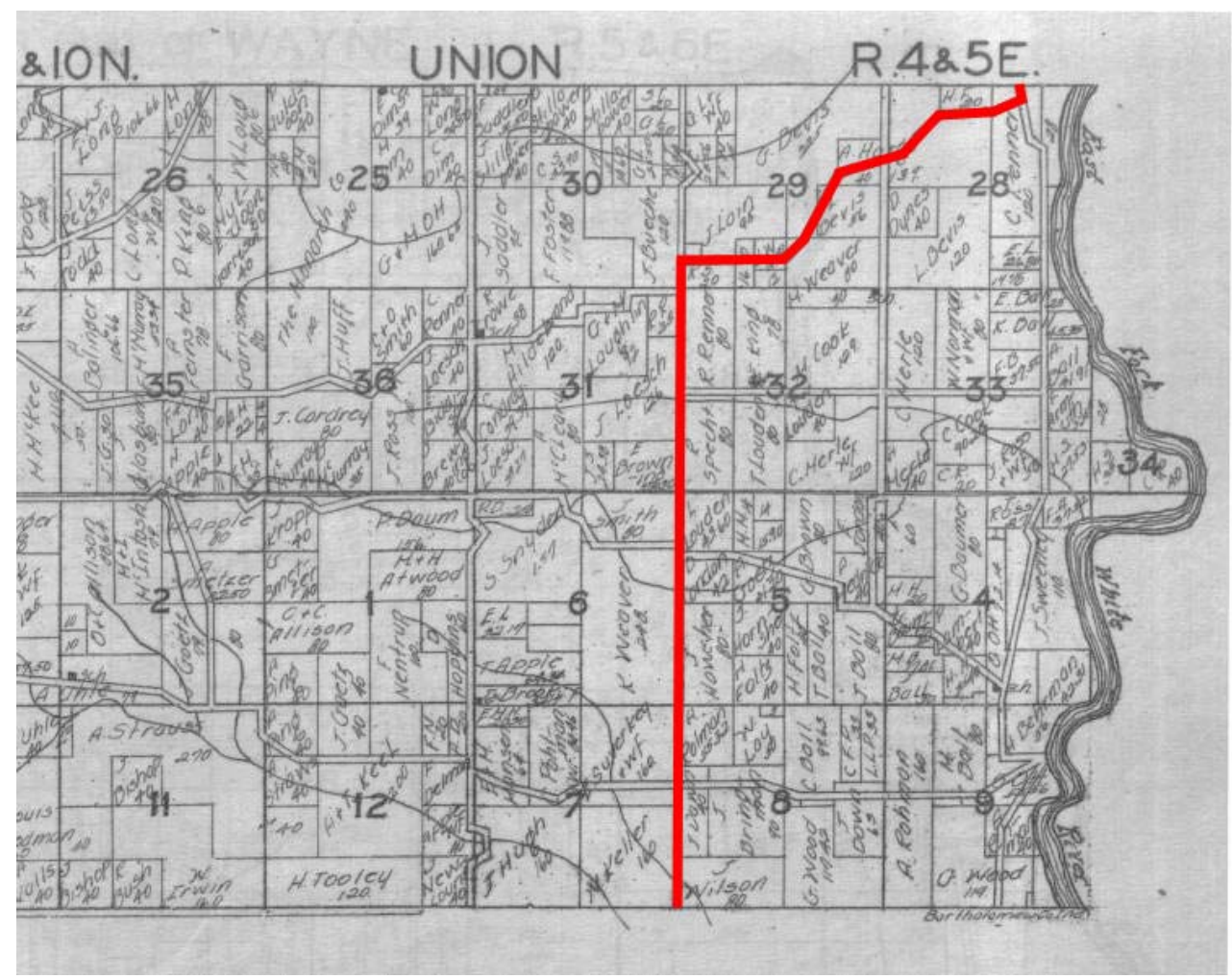

Figure 36. Union Township, Bartholomew County Plat Map, circa 1925 to 1941 (courtesy IUPUI Digital Map Collections on-line). 


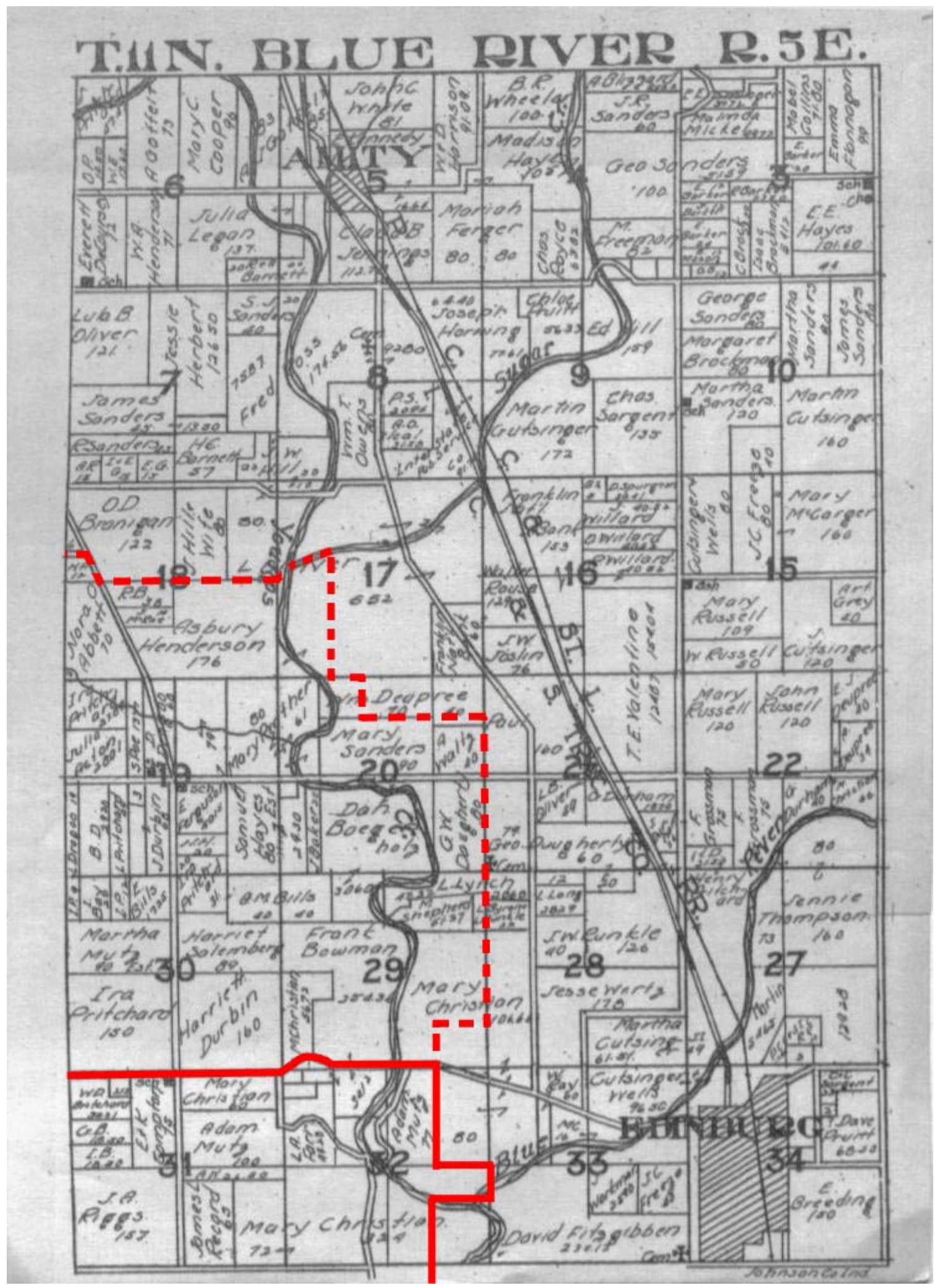

Figure 37. Blue River Township, Johnson County Plat Map, circa 1925 to 1941 (courtesy IUPUI Digital Map Collections on-line). 


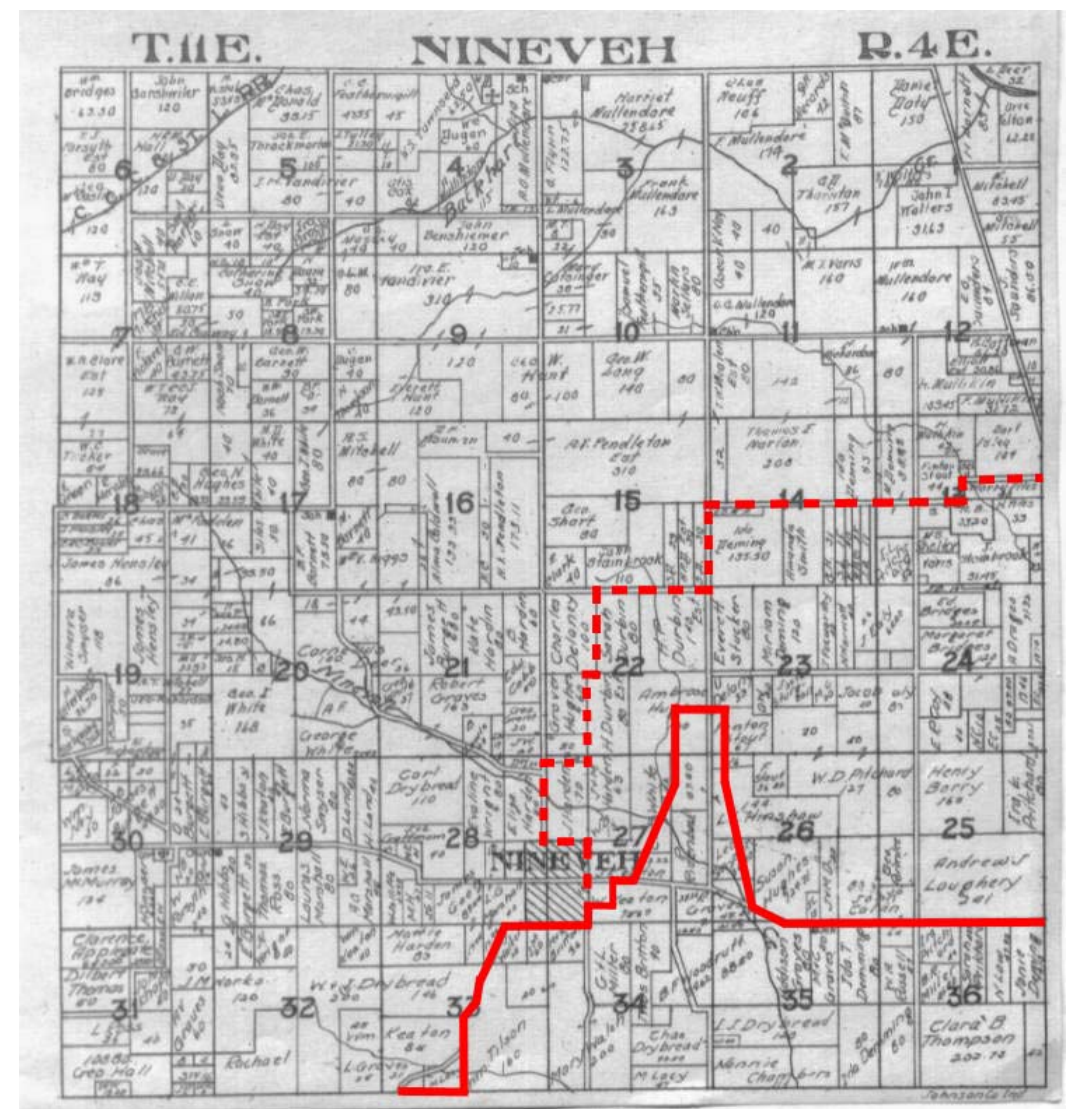

Figure 38. Nineveh Township, Johnson County Plat Map, circa 1925 to 1941 (courtesy IUPUI Digital Map Collections on-line).

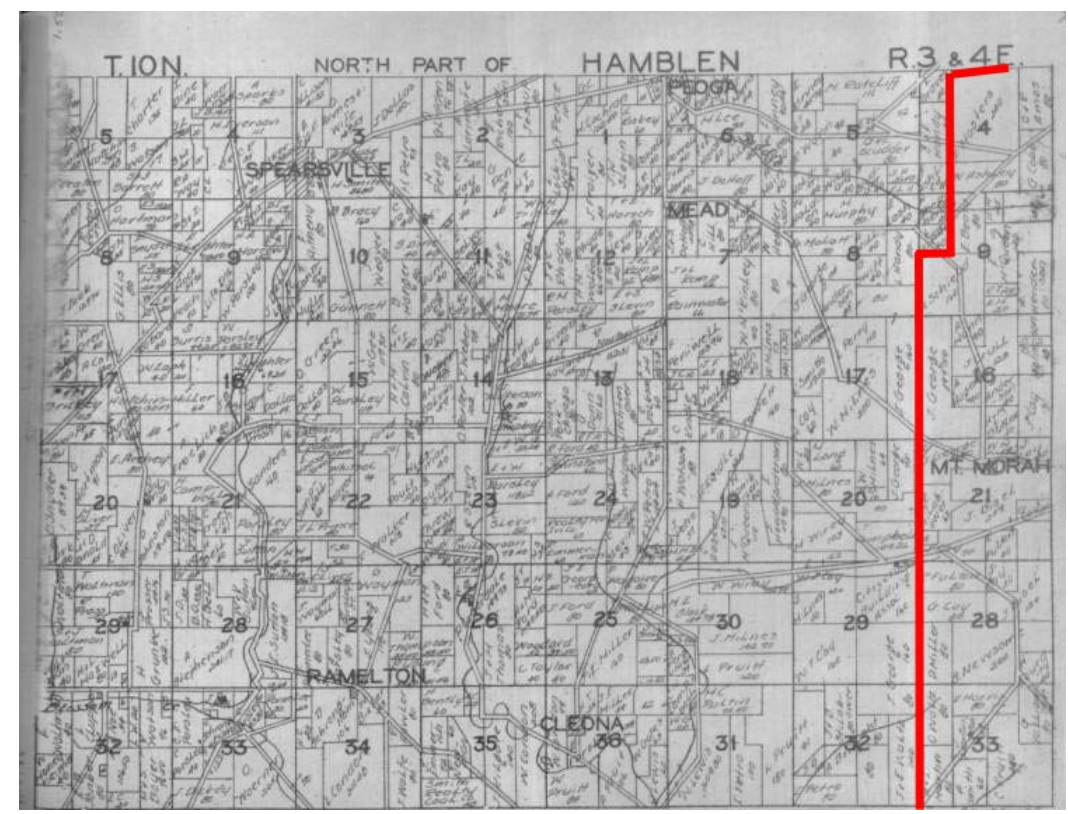

Figure 39. Hamblen Township, Brown County Plat Map, circa 1925 to 1941 (courtesy IUPUI Digital Map Collections on-line). 
Table 19. Crop production for Camp Atterbury Townships, 1920 to 1940. Wheat, rye and oats, and corn in bushels, wool, tobacco, and butter/cheese in pounds, and hay in tons.

\begin{tabular}{|l|l|l|l|l|r|r|c|}
\hline County & Wheat & Rye and Oats & Corn & Wool & Hay tons & Tobacco & Butter/Cheese \\
\hline Bartholomew 1920 & 923,718 & 172,692 & $1,766,771$ & 17,024 & - & 3,631 & 168,000 \\
\hline Bartholomew 1930 & 486,548 & 107,723 & $1,449,990$ & 19,173 & 27,111 & 225,521 & 57,040 \\
\hline Bartholomew 1940 & 422,782 & 36,483 & $1,979,318$ & 27,158 & - & 305,668 & - \\
\hline Johnson 1920 & 966,749 & 98,414 & $1,656,668$ & 26,347 & - & 7,230 & 140,770 \\
\hline Johnson 1930 & 596,679 & 154,930 & $1,659,185$ & 39,027 & 32,168 & 35,477 & 43,751 \\
\hline Johnson 1940 & 473,655 & 73,219 & $2,511,505$ & 40,143 & - & 125,737 & - \\
\hline Brown 1920 & 57,104 & 39,602 & 366,805 & 10,037 & - & 12,933 & 144,074 \\
\hline Brown 1930 & 2,897 & 4,439 & 126,700 & 4,184 & 7,698 & 118,477 & 48,758 \\
\hline Brown 1940 & 3,812 & 225 & 193,463 & 2,403 & - & 20,766 & - \\
\hline
\end{tabular}

Table 20. Livestock production in Camp Atterbury Townships, 1920 to 1940.

\begin{tabular}{|l|c|c|c|c|}
\hline County & Horses/Mules & Cattle/cows & \multicolumn{1}{l|}{ Sheep } & Swine \\
\hline Bartholomew 1920 & 9,278 & 15,460 & 4,131 & 45,413 \\
\hline Bartholomew 1930 & 6,570 & 13,754 & 5,978 & 26,650 \\
\hline Bartholomew 1940 & 3,024 & $12,288 / 6,327$ & 4,299 & 18,913 \\
\hline Johnson 1920 & 10,306 & 17,548 & 4,999 & 55,187 \\
\hline Johnson 1930 & 5,988 & 17,481 & 11,749 & 47,968 \\
\hline Johnson 1940 & 4,098 & $19,508 / 8,275$ & 6,345 & 36,012 \\
\hline Brown 1920 & 3,471 & 5,609 & 2,066 & 7,787 \\
\hline Brown 1930 & 1,786 & 3,289 & 1,477 & 2,410 \\
\hline Brown 1940 & 1,068 & $2,732 / 1,564$ & 504 & 2,648 \\
\hline
\end{tabular}

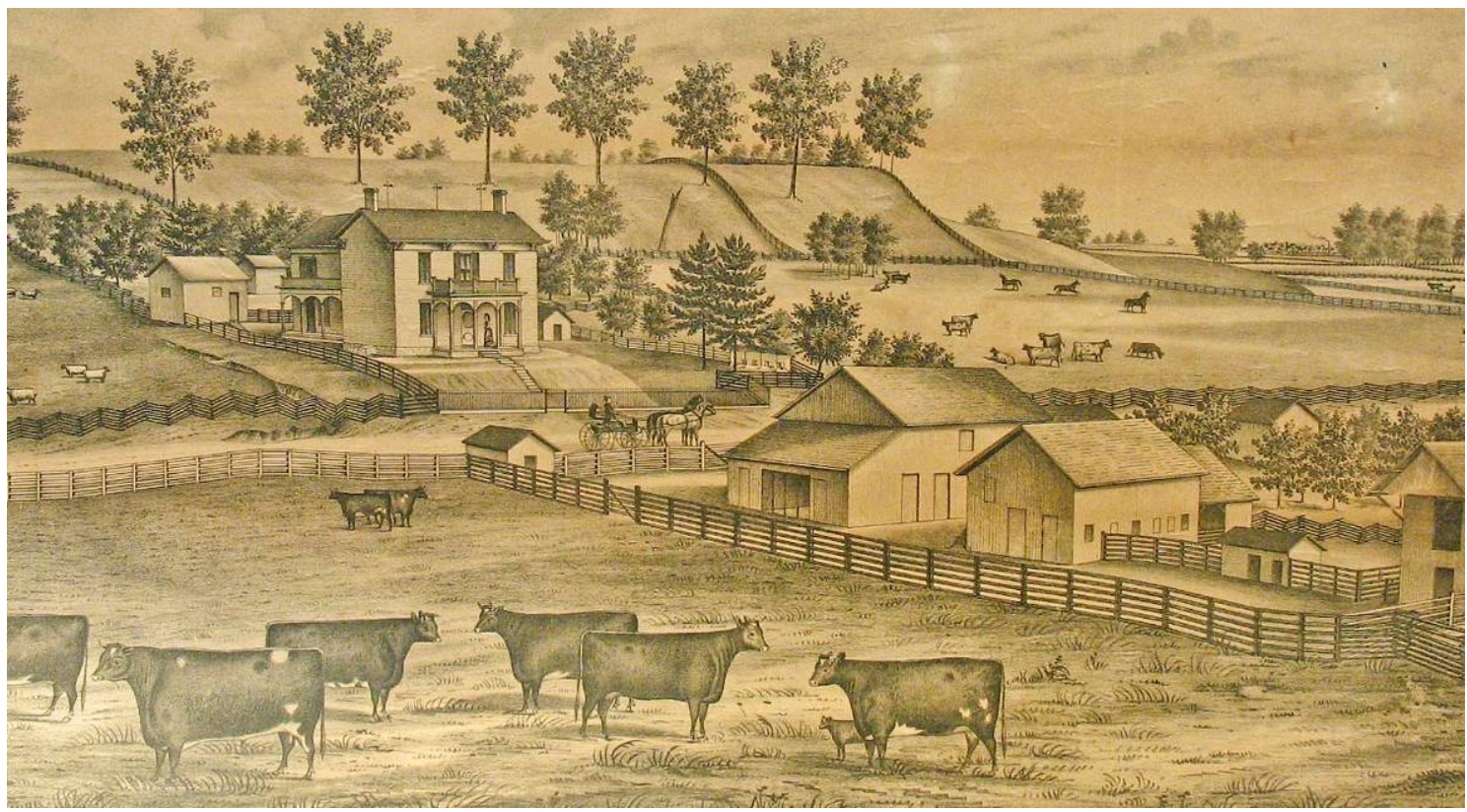

Figure 40. Although from an 19th century atlas, this farm scene is typical of a diversified "stock" farm on the edge of the Tipton Plain in Johnson County in the early 20th century (from Atlas of Johnson County). 
While agricultural production levels indicate a slight loss around the beginning of the Depression, with gains toward its end (probably caused by the war in Europe increasing demand), the change in farm sizes and ownership provide some insights into the effect of the Depression on the tricounty area. The data listed in Tables 21, 22, and 23 indicate that farm ownership in Bartholomew and J ohnson Counties dropped significantly from the 1920s to the 1930s and then recovered somewhat in 1940.

J ohnson County private farm ownership dropped below 50 percent and just barely recovered by 1940 . Even the number of farms dropped, probably due to consolidation of some farms (note that large farms of over 260 acres increased during this period in the two counties). This consolidation may be due to some farmers losing their property through bankruptcy and subsequent purchase by others at bargain prices.

In Brown County, there was significantly greater change in the culture and economy. Brown County's crop and animal production dropped across the board, except for tobacco. This is a direct reflection of the county's change from a rural isolated small-farm region to a tourist and art mecca. The combined effects of $19^{\text {th }}$ century logging and over-use of the thin hill soils made farming increasingly difficult during the $20^{\text {th }}$ century in Brown County. Brown County farmers faced the potential for bankruptcy long before the Depression in the late $19^{\text {th }}$ century and again in the mid 1920 s (Nicholson 1992:154).

Table 21. Farm sizes and percent ownership for Bartholomew County, 1920 to 1940.

\begin{tabular}{|l|c|c|c|c|c|c|c|c|l|}
\hline Bartholomew County & Under 10 & 10 to 49 & 50 to 99 & 100 to 174 & 175 to 259 & 260 to 499 & 500 \& Over & Total Owner & $\begin{array}{l}\text { Total } \\
\text { Farms }\end{array}$ \\
\hline 1920 & 64 & 387 & 568 & 655 & 237 & 107 & 25 & $1,380(68 \%)$ & 2,043 \\
\hline 1930 & 145 & 397 & 450 & 555 & 255 & 119 & 17 & $977(50 \%)$ & 1,938 \\
\hline 1940 & 134 & 354 & 424 & 503 & 218 & 162 & 20 & $1,009(56 \%)$ & 1,815 \\
\hline
\end{tabular}

Table 22. Farm sizes and percent ownership for Brown County, 1920 to 1940.

\begin{tabular}{|l|c|c|c|c|c|c|c|c|c|}
\hline Brown County & Under 10 & 10 to 49 & 50 to 99 & 100 to 174 & 175 to 259 & $\mathbf{2 6 0}$ to 499 & $500 \&$ Over & Total Owner & Total Farms \\
\hline 1920 & 36 & 314 & 468 & 409 & 152 & 66 & 13 & $1,169(80 \%)$ & 1,458 \\
\hline 1930 & 14 & 146 & 279 & 283 & 107 & 36 & 9 & $601(68 \%)$ & 874 \\
\hline 1940 & 29 & 206 & 258 & 260 & 85 & 38 & 7 & $688(77 \%)$ & 883 \\
\hline
\end{tabular}

Table 23. Farm sizes and percent ownership for Johnson County, 1920 to 1940.

\begin{tabular}{|l|c|c|c|c|c|c|c|c|c|}
\hline Johnson County & Under 10 & 10 to 49 & 50 to 99 & 100 to 174 & $\mathbf{1 7 5}$ to 259 & $\mathbf{2 6 0}$ to 499 & $\mathbf{5 0 0} \&$ Over & Total Owner & Total Farms \\
\hline 1920 & 164 & 426 & 659 & 558 & 171 & 67 & 6 & $1,259(61 \%)$ & 2,051 \\
\hline 1930 & 142 & 404 & 556 & 520 & 166 & 81 & 7 & $811(43 \%)$ & 1,876 \\
\hline 1940 & 211 & 436 & 508 & 520 & 166 & 96 & 8 & $954(49 \%)$ & 1,945 \\
\hline
\end{tabular}


This problem was endemic to southern Indiana counties:

[In] Brown and Monroe counties on the northern edge of the region, south to the Ohio River counties. ... many Hoosier farmers struggled to eke out a living, often on the edge of subsistence, much as their grandparents had before the Civil War (Madison 1982:166).

Brown County agriculture was also hit hard with the drop in crop prices after WWI. Indiana farmers' success in increasing yields through better farming practices, conservation, and technology served only to exacerbate this price drop. "Farms increased production during WWI made good money, but the bottom fell out of market afterward. Then increases in yields ironically acted against farmers as prices dropped with surplus crops" (Madison 1982:170). Meanwhile, artists and tourists discovered the hills of Brown County through the early and mid-20 ${ }^{\text {th }}$ century. Farms were purchased by wealthy Indianapolis businessmen, including such people as P.F. Goodrich, as weekend or summer getaways. More and more farms became available as bankruptcy increased. The number of farms in Brown County dropped nearly 50 percent between 1920 and 1930. Some farmers, unable to make a living in agriculture, turned to making moonshine or "white mule" (Nicholson 1992:189).

Government programs attempted to solve some of Indiana farmer's problems during the 1930s. For instance, in the 1930s, soybeans were introduced and it became a popular crop. In fact, the state was second in the nation in soybean production by 1939. Interestingly, though, the tri-county region did not convert to soybeans immediately. In 1940, Bartholomew County produced only 13,032 bushels of soybeans, J ohnson County produced only 8913, and Brown produced only 261 bushels (U.S. Census of Agriculture 1940). During the 1930s, government agents and agricultural schools like Purdue University attempted to introduce hybrid seeds to increase yields. Exactly how Camp Atterbury farmers responded to this development is unknown. One historical source said that hybrid corn was planted as early as 1931 in Bartholomew County (Marshall and Prather 2003:66) while another stated that a hybrid seed was not introduced until 1938 (Madison 1982:157).

While Brown County subsistence farmers struggled, some of the larger farms in the county turned to commercial fruit production. One of the largest orchards was at Hickory Hill in the north central part of the county. The owner B.W. Douglas employed a number of people at his orchard and cannery during the Depression (Bailey 1991:51). Within old Camp Atter- 
bury, there was an orchard along Catherine Creek in Nineveh Township, Bartholomew County, owned by the Allison family (Marshall and Prather 2003:91). Allison Orchards totaled some 330 acres, and in the 1930s, the two sons of the original owner spilt-up the family land. They grew apple, peach, cherry, and plum trees, and also had blackberry, raspberry, and strawberry patches. There may have been more commercial orchards than the Allison's within Camp Atterbury. Mead in Taulman and Wertz (1999:59) noted that when the Army acquired Camp Atterbury, "The land wasn't exceptional for farming, but it had some of the best producing orchards in the state."

Much of the fruit from these orchards was canned (Figure 41). Canning in Brown County became a significant industry not only for fruit canning, but also for tomatoes. Over-regulation by the government Work Projects Administration (WPA) programs, however, brought the canning industry to a halt in Brown County in 1935 (Bailey 1991:82). This may explain the low production of tomatoes in the 1940 census. Bartholomew devoted only 3285 acres, J ohnson 1212 acres, and Brown County only 510 acres to tomatoes in 1940 (U.S. Census of Agriculture 1940). In 1929 and 1938, Indiana had the largest number of acres devoted to tomato production of any state (Madison 1982:154).

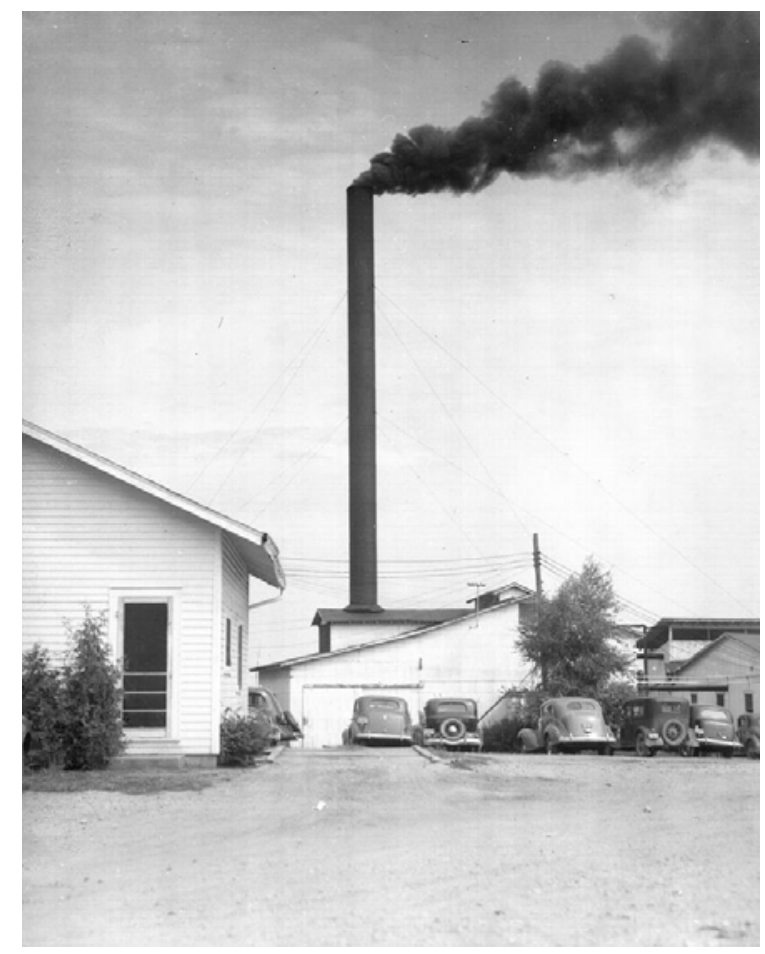

Figure 41. Canning Factory in Trafalgar, Johnson County Indiana, just north of Brown County (Courtesy Johnson County Historical Society Museum). 


\section{Technology and the $20^{\text {th }}$ century farmer}

Indiana and tri-county farmers were slow to accept some modern conveniences and rapid to accept others. For instance, in the early 1930s, only 16.7 percent of Indiana farms had electricity (Madison 1932:171). By 1940, 51.8 percent of Indiana farms had electricity while 98 percent of urban dwellings had electricity. The number of telephones in rural Indiana actually declined through the first half of the $20^{\text {th }}$ century. Some 66 percent of Indiana farms had telephones in 1920, 61 percent had phones in 1930, but only 45 percent had telephones in 1940. In 1940, only 15 percent of Brown County farms had telephones (Madison 1982:172).

On the other hand, Indiana farmers took rapidly to the automobile. By 1940, Bartholomew County had 1800 automobiles on its 1815 farms. J ohnson County had 1955 automobiles on 1945 farms. That same year, Brown County had 500 automobiles on 883 farms. For the tri-county region the total number of automobiles was 4255 on 4643 farms, or, 91 percent of the farms in the tri-county region had an automobile. Compared to the number of automobiles at the state level, the area was above average in automobile ownership. In 1920, 46 percent of Indiana farms had an automobile, in the 1930s, 70 percent, and in 1940, 81 percent (Madison 1982:157). Thus the tri-county region had 10 percent more automobiles than the state average at the beginning of WWII. Trucks were also popular. There were 404 trucks in Bartholomew County, 476 in J ohnson County, and 128 in Brown County in 1940.

Tractors were also popular. In 1940, Bartholomew County had 803 tractors, while J ohnson County had 967 tractors, and Brown County had 111 tractors. In 1920, only 4 percent of Indiana farms had tractors, but the number grew to 22 percent in 1930 and 37 percent in 1940 (Madison 1982:155). The tri-county region was slightly higher than the state numbers in tractors in 1940 .

The use of automobiles, trucks, and mechanical farm implements served to change the social interaction in the community during this period. The use of threshing crews nearly disappeared. With gasoline-powered equipment, farmers could plant and harvest their crops using fewer hired laborers. Since threshing in the late $19^{\text {th }}$ century was an annual community event that included all members of the family, social ties were probably weakened by this change. Ironically, late $19^{\text {th }}$ century farm mechanization had served to increase yields and drew communities together in threshing teams, the efficiency of later innovations had the opposite effect. 


\section{Industries}

As has been discussed in previous chapters, Camp Atterbury was never a significant industrial region. Temporary lumber mills and tanneries were the only industries within the camp borders, except for Collier's grist mill along the Driftwood River. Grain harvested within the camp's borders was milled in Franklin, Edinburgh, Taylorsville, and Columbus during the late $19^{\text {th }}$ century. Around the turn of the century or later, local harvests were taken to grain elevators along the main railroad line where the grain was stored until the farmer obtained the best price. Then it was milled and shipped to distant markets. As a result, around the first quarter of the $20^{\text {th }}$ century, the two mills near Camp Atterbury lost their central importance to the community.

There were still mills in Columbus and Franklin, but as milling technology no longer relied on water power, the Driftwood River mills eventually closed (Figure 42). The Thompson Mill in Edinburgh, for instance, ground corn until around WWI. Afterward the owners attempted to use the dam to generate electricity. When the owners moved to Illinois in 1922, the mill stood abandoned until circa late 1950s, when it was torn down (Otto 1987:17). Furnas Mill burned when struck by lightning in 1913. It took on a new role `and 1930s as an attraction for recreation like fishing and camping. Summer cottages were built along the river bank (J CHS Vertical Files, newspaper article dated 8 August 1913). A grocery store was established. The grocery had a huckster wagon that traveled the country roads filled with fresh vegetables and fruit for sale to local farmers (Hughey in Taulman and Wertz 1999:24). The mill site and summer cottages were locally known as Harvest City (Blake n.d. :34; Taulman and Wertz 1999:11).

In Edinburgh, the Cutsinger Elevator Company became an important distribution point for north Camp Atterbury grain farmers. It opened in 1871 and continued operations until it burned in 1948. In the same town, Community Mill was established in 1921 and was able to remain open until just before WWII (Otto 1987:85). During the $20^{\text {th }}$ century Columbus was the main processing point for Camp Atterbury livestock. Milk was sent to Columbus dairies, fruit and vegetables were sent to Columbus canneries, hogs and beef to Columbus meat-packing plants, and chickens to Columbus poultries (Marshall and Prather 2003:106-113). Farm implements were purchased in Columbus with the monies earned from harvests. Overall, by 1940, small industries like tanneries and mills were largely gone in the Camp Atterbury region. Some farmers still maintained small portable mills to cut lumber for the farm and to sell locally. 


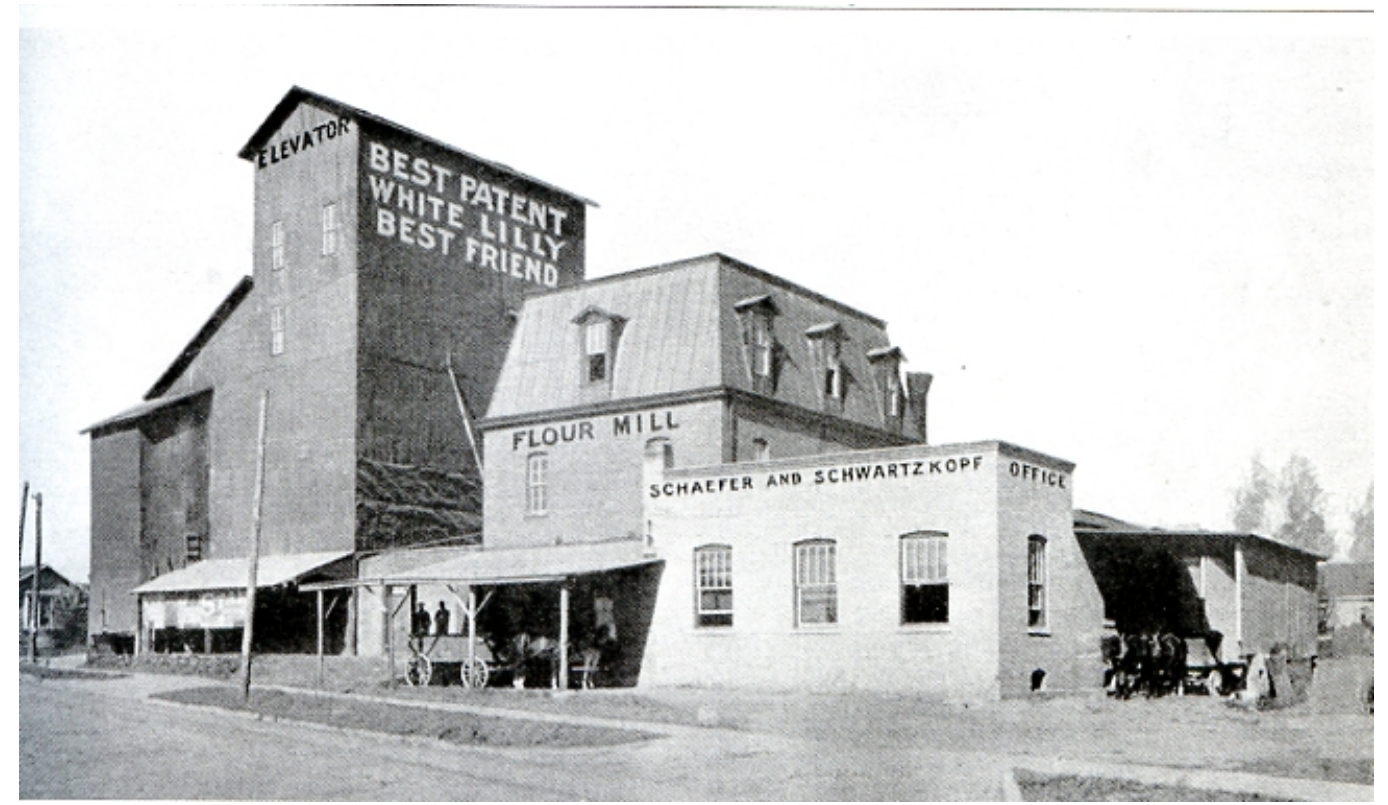

Figure 42. Schaefer and Schwartzkopf Mill and elevator in Columbus, IN. Camp Atterbury farmers turned to large mills in the 20th century once roads were improved (from Marshall and Prather 2003:103).

Two other industries came to the region during this period. After the timber industry in the late 1880s had devastated the Brown County landscape and the county had largely turned to tourism, there was a major conservation effort to reclaim the eroded hillsides through a state-sponsored reforestation program (Nicholson 1992:217). This reforestation was conducted by state conservation workers and its likely some Camp Atterbury residents sought employment in this program. Through the 1920s, Brown County's tourism "industry" grew as more and more visitors from Indianapolis and other urban areas visited. Brown County residents responded by inventing ways to make a living from tourism. By 1930 tourism was the "main economic enterprise" of the county (Nicholson 1992:213). However, tourism was not all positive for the county residents. Some Brown County natives found the visitors intrusive as they drove along county roads photographing the houses and people. This activity no doubt was exacerbated by professional photographer Frank Hohenberger, who fell in love with the county and took hundreds of photographs of Brown County people and landscape. Besides photography, Hohenberger started writing a humorous weekly column in the Indianapolis newspaper entitled "From Down in the Hills O' Brown," which served again to increase outside interest in the county (Nicholson 1992:163). Still, tourists wanted mementos of their visits. Slowly, reluctant Brown County residents adopted once necessary handicrafts (i.e., weaving and basket making) for sale to tourists (Nicholson 1992:201-203). 


\section{$20^{\text {th }}$ century social life}

Churches and schools remained the primary focus of community activities and social order throughout this period. There was very little if any change in the number or denomination of churches between 1920 and 1940. As previously noted, pioneers rapidly organized overwhelmingly Protestant congregations during the initial occupation of the camp. Congregations began in private homes, but soon they built separate churches. By the late 19th century, Methodists, Christians, Baptists (and a few Catholics) dominated the area. By the mid $20^{\text {th }}$ century these same congregations had seen several generations pass through their church doors (Figures 43 and 44).

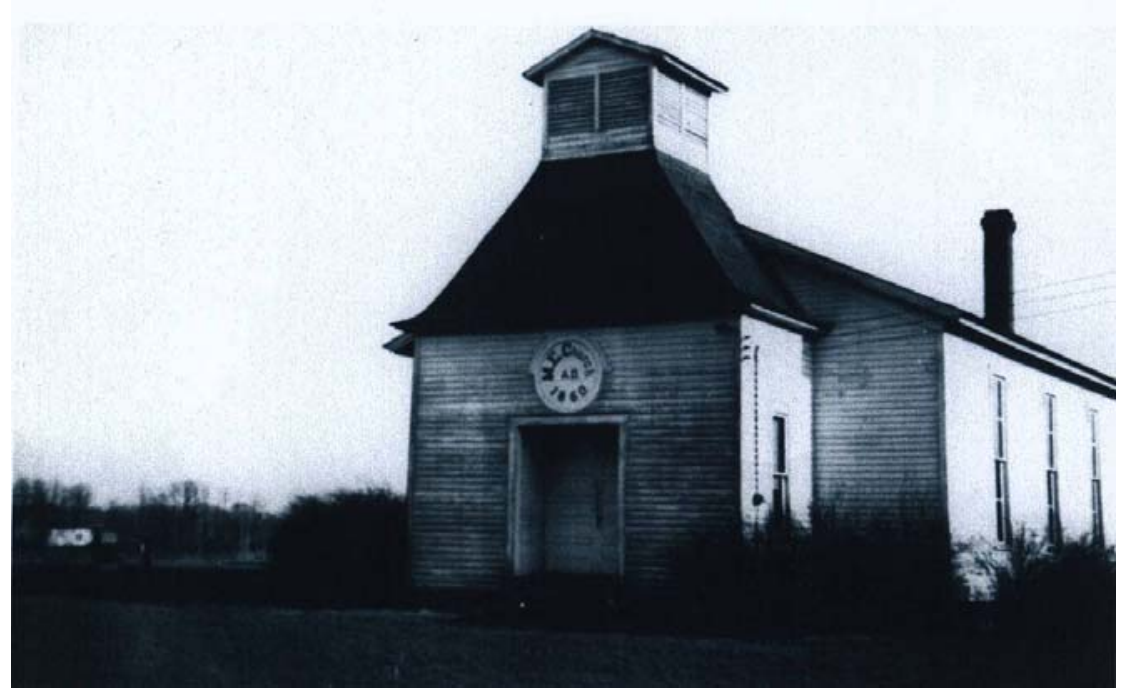

Figure 43. Kansas Methodist Church, circa 1940s (courtesy Camp Atterbury Museum).

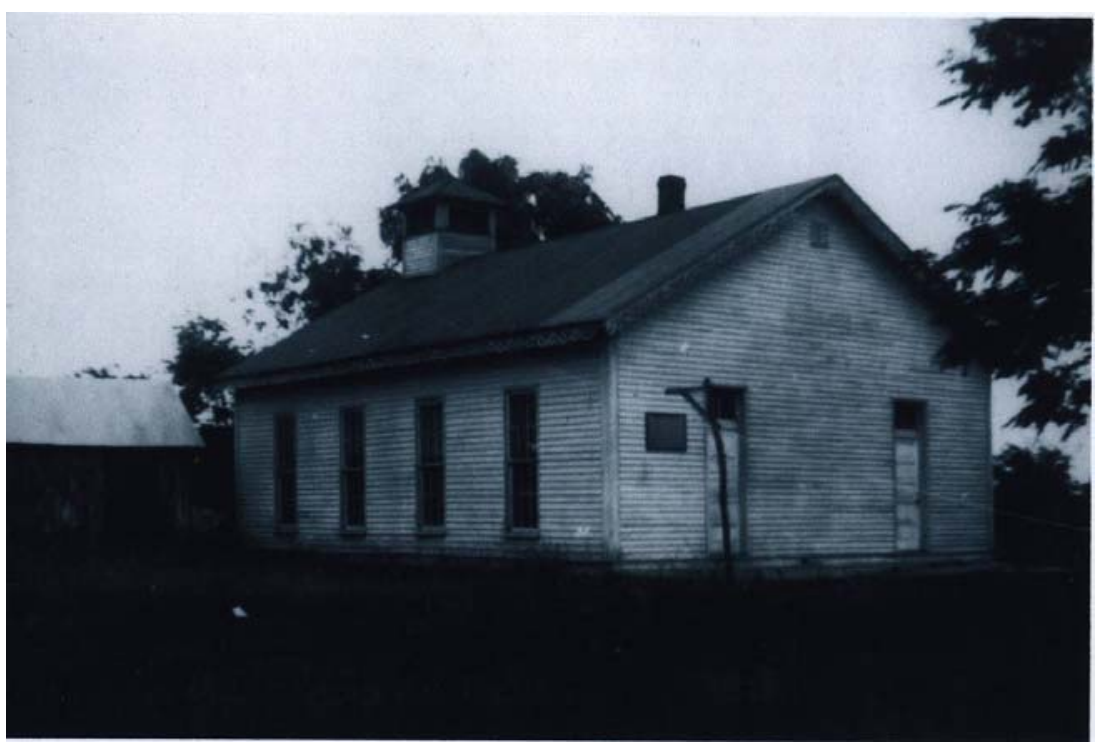

Figure 44. Ohio Ridge Church, circa 1940s (courtesy Camp Atterbury Museum). 
In 1928, Harley Talley wrote a thesis describing Bartholomew County schools. He recommended consolidation of the schools in Nineveh Township into one large school. At that time, 94 students out of 141 children attended the township school (Talley 1928:188, 220). Nineveh Township had four one-room schools (Kansas, Records, Neville, Drybread), while Union township had two one-room schools (Lowell and Precinct). The schools only had one teacher (Talley 1928:44, 45, 189). All of the schools had outdoor toilets, poor lighting, and wood stove heating. According to Talley, the children had above average attendance and the teachers were good, but they showed "little desire" to change teaching methods (Talley 1928:233). As part of his argument for consolidation, he noted "No small town furnishing a community center is anywhere within the township and the school building would serve the social life of the people. And, of course, the school facilities would be tremendously extended and improved" (Talley 1928:222).

Providing some insight into the lifestyle dichotomy between NinevehUnion residents and Bartholomew County residents in the eastern part of the county, Talley noted, "The good farms on the east, the splendid ones in the central part of the county, and the poor ones on the west reflect their incomes and power to bear taxation in the standard of living, social life, and the schools of the county" (Talley 1928:11). Talley believed that the western townships would have to have state assistance to improve their schools (Talley 1928:235).

Apparently Talley's recommendations were taken seriously. When Camp Atterbury was established, Nineveh Township had only three schools remaining in the township-Records, Kansas, and Hog Bottom, with 85 elementary and 30 high school students (Figures 45 and 46). The high school students were attending either Edinburgh or Nineveh high school in J ohnson County (Marshall and Prather 2003:213). Likewise, Union Township only had two schools with 119 students, the Precinct School and Lowell School. The Lowell School was the original one room building built in 1870 and was used until 1942 (Marshall and Prather 2003:218).

While churches and schools were the binding agents of the rural community, other organizations performed the same function. For a farming community, youth farm organizations were the strongest. In 1914, \$-H clubs began, and in the 1920s and 1930s became an integral part of the community. There were corn clubs, swine clubs, baking clubs and others. 


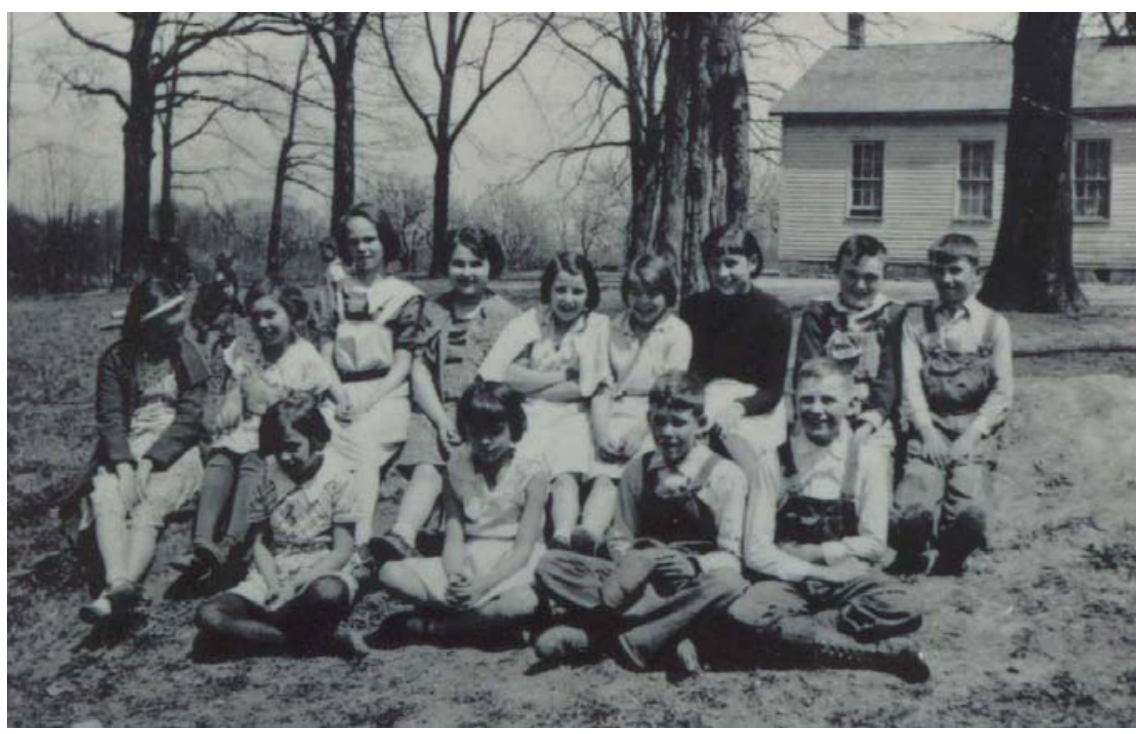

Figure 45. Precinct School, circa 1930s (courtesy Herman Johnson).

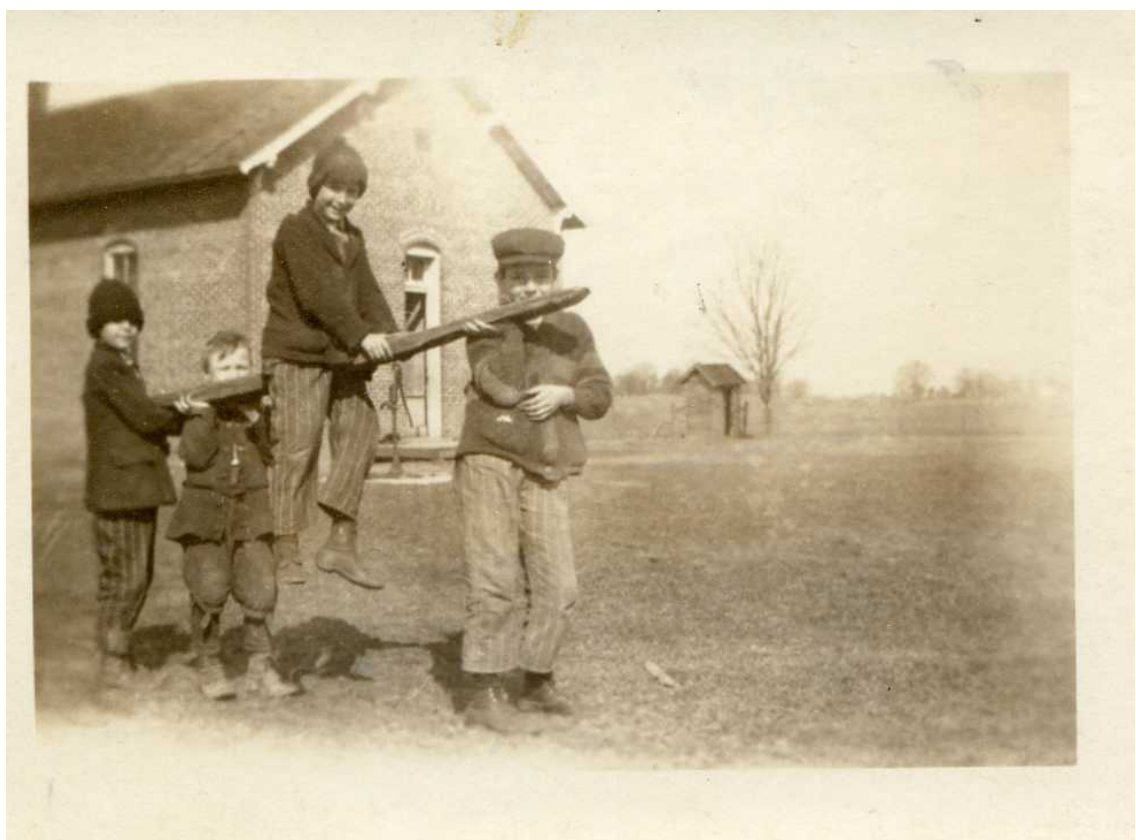

Figure 46. Kids in front of Records School, circa 1920s (courtesy Herman Johnson).

In 1923, there were 162 members of various 4-H clubs in Bartholomew County, and the club's popularity peaked during WWII with as many as 1600 members (Marshall and Prather 2003:75). For adults, the Grange, started in the late $19^{\text {th }}$ century, continued to play an important part in the community. Also, the Bartholomew County Farmer's Association was formed in the early part of the $20^{\text {th }}$ century. In 1923, a state organization called the Indiana Farm Bureau Federation was organized, and it would appear that the Bartholomew County Farmers Association was eventually absorbed by the state organization. The bureau assisted farmers in mar- 
keting products, demonstrating new technologies, and representing farmer economic interests. This included organizing cooperative markets where farmers could buy supplies inexpensively in bulk (Marshall and Prather 2003:80-81).

Secret "regulator" societies unfortunately continued and, in the 1920s, the KKK had a brief revival (Nicholson 1992:206-207). In Brown County members gained support and power in local business and governmental affairs. The local newspaper, the Brown County Democrat, openly endorsed the Klan as their "activities cause[d] no apprehension on the part of anyone" (Brown County Democrat quoted in Nicholson 1992:209). Franklin, IN was another KKK stronghold, the first meeting held there in 1923. Most of their activities were aimed at Catholics. Klan members feared that the public schools were hiring priests as teachers to convert Protestant children (Blee 2002:133). However, the author could find no recorded incidents of outright violence in the tri-county region.

\section{Transportation}

As indicated, the automobile made a dramatic and immediate impact. The need for better roads was quickly realized and the state of Indiana took steps to improve the dirt wagon roads that ran through the countryside. In 1919, Indiana created the State Highways Commission and in 1932 state law transferred authority for roads from townships to county commissions (Madison 1982:186, 191)-long before the transfer roads improvements were made. By 1925, Indiana had 1203 paved roads and 2658 improved gravel roads. One of the first roads improved was the Mauxferry road, paved around 1921, demonstrating the importance of this main artery between Louisville and Indianapolis (Taulman and Wertz 1999:28). The State Road 46 from Columbus to Nashville was blacktopped in 1935 long after the Mauxferry road (Bailey 1991:83).

Gasoline-powered transportation stunted the growth of the interurban rail line. By the early 1920s, the interurban rail system was already threatened. Through the 1920s and 1930s, wise interurban companies converted to bus lines, and shrank their rail network. Still, the main line from Edinburgh to Indianapolis, operated by the Interstate Pubic Service Company, survived until 1941 (Madison 1982:197).*

\footnotetext{
* http://sbcglobalpwp.att.net/w/i/willvdv/interin.html
} 
Harley Talley provided insight into the state of roads in the Camp Atterbury region. Talley noted that the roads in Nineveh Township in 1928 were of mixed quality. "The roads on the north and east [near Edinburgh] are excellent. The roads in the southwest and in the extreme western border are poor but can be built into shape" (Talley 1928:222). At the time the camp was constructed, there were around 130 miles of roads in the Bartholomew County section (Bartholomew County total at the time was 773 miles), including 10 miles of blacktop (probably most of this along the Mauxferry road) (Columbus Republican 29 May 1941). A 1912 touring map depicts the roads in Camp Atterbury at that time (Figure 47). Although it was published before 1920, it does provide a clear picture of the road system for the period between 1920 and 1930, and re-emphasizes how early the automobile became part of the American scene.

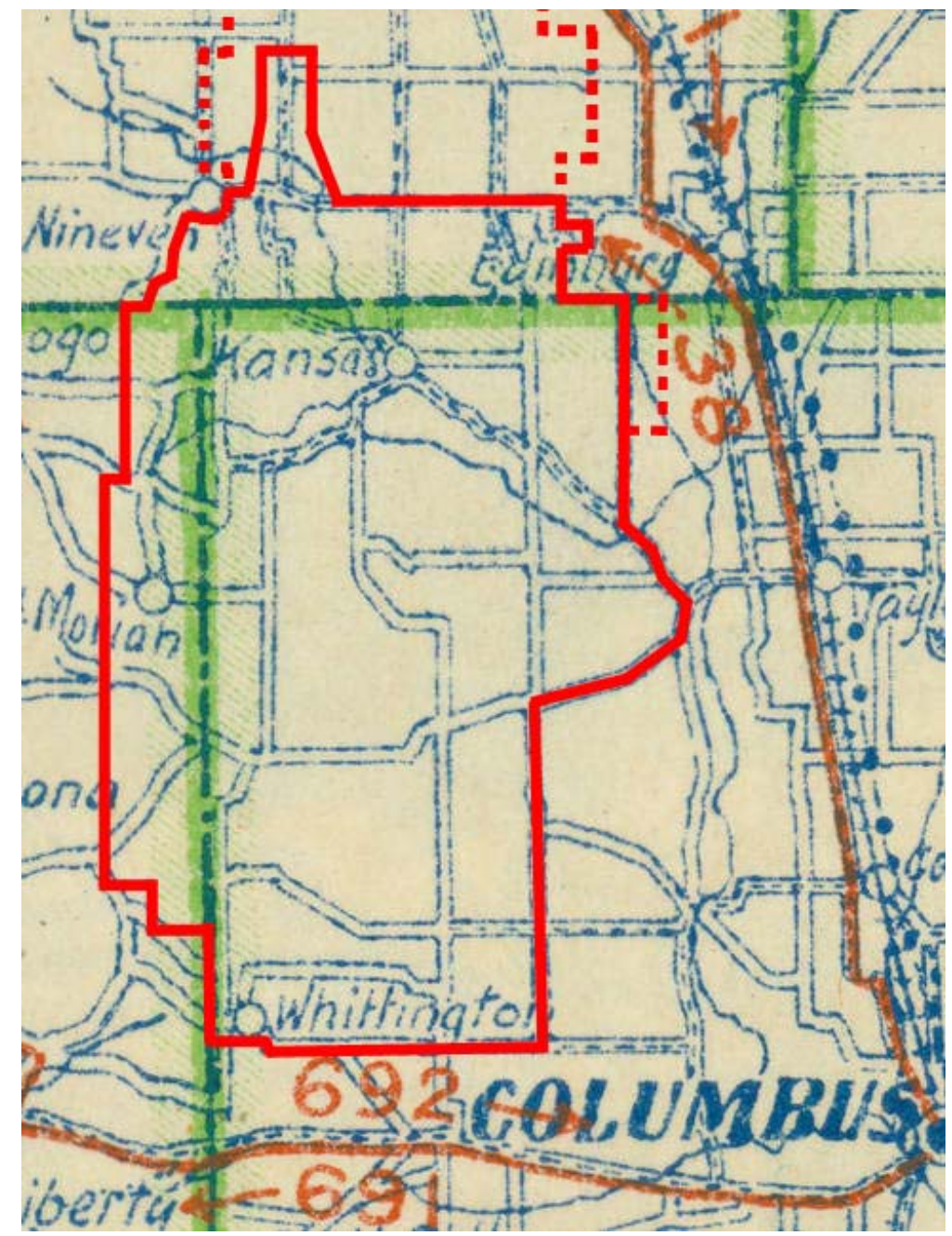

Figure 47. This enlargement of a 1912 touring map indicates the better roads in the Camp Atterbury region during the first half of the $20^{\text {th }}$ century (from Scarborough's Road Map and Motor Guide of Indiana, 1912). 


\section{Towns}

Automobiles broke the isolation of the Camp Atterbury region. The automobile contributed to the growth and importance of Edinburgh, Columbus, and to a lesser extent, Franklin. Camp Atterbury residents used autos to quickly access markets, doctors, banks, and grocers. They used trucks to get their crops to the grain elevators and their livestock to Columbus slaughter houses. In turn, places like Nineveh, Kansas, Pisgah, Mt. Moriah (and perhaps Whittington?) lost their importance to the community. The automobile also changed community social ties because Edinburgh and Columbus schools and churches became accessible. Through this transition, smaller hamlets failed to grow.

Kansas is a case in point. At the time of Army acquisition in 1942, Kansas consisted of only five houses, a blacksmith shop, a general store (including a filling station), two churches and a school. The Dinn's, who owned the little store, also ran a little rental library (Figure 48). Although Kansas never grew beyond a small hamlet, it was a popular place on weekends. Mrs. Franklin Dinn noted in 1941just before it was taken over by the Army that, "On Saturday nights the store's so crowded you can hardly get in" (Fifer, 1941; Taulman and Wertz 1999:3). In J ohnson County, the Pisgah community remained a recognizable place between Nineveh and Edinburgh consisting of the Calvin School and two churches. Mt. Moriah in Brown County never achieved Kansas's status as a central place and eventually was no longer shown on contemporary maps.

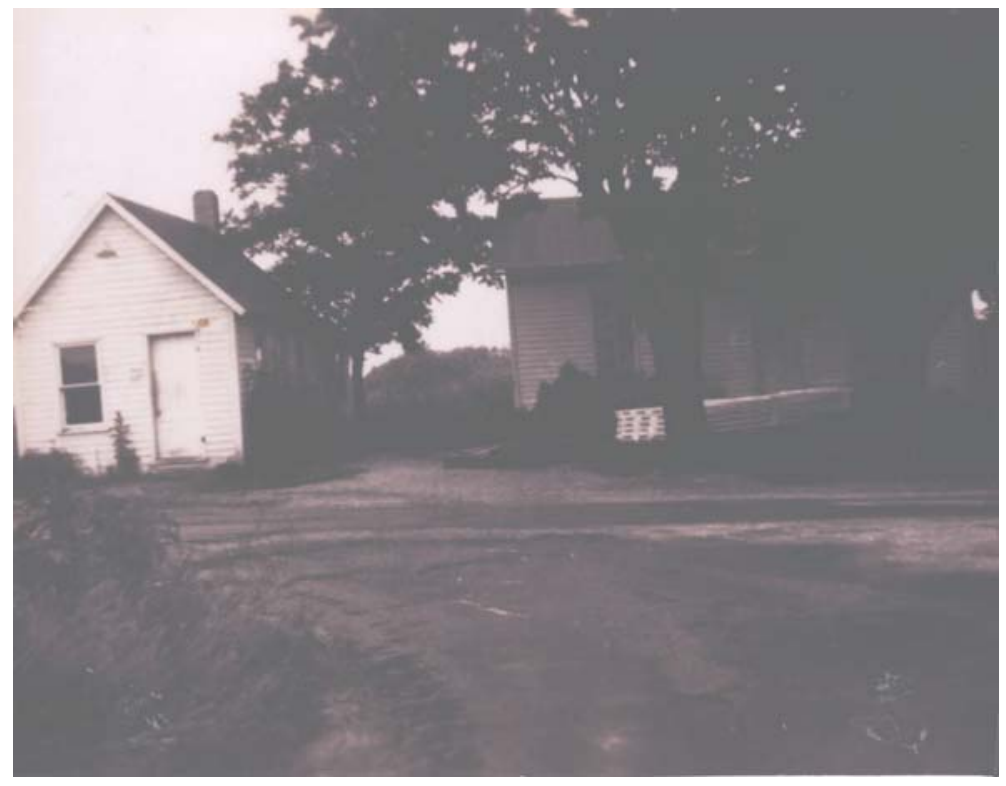

Figure 48. Dinn Store at Kansas shortly before Army Acquisition (courtesy Camp Atterbury Museum). 
The real action was in the larger towns outside of Camp Atterbury. Edinburgh was described in the Works Progress Guide as a "brisk country town, has a canning factory, a large veneer mill, and a furniture factory" (American Guide Series 1941:439). The veneer industry, which began in the late 1890s, grew throughout the 1920s and 1930s, eventually making Edinburgh the "Veneer Capitol of the USA" in the 1950s (Otto 1987:87).

The 2003 history of Bartholomew County demonstrated the importance of Columbus in the lives of Camp Atterbury residents. Nearly all of this history revolved around industry, education, arts, preservation, agri-business, and the architecture of Columbus, IN (Marshall and Prather 2003). One section was headed "Small Towns Lose Their Identity," which accurately summed up the 20 $0^{\text {th }}$ century urban history of Bartholomew County and, by extension, Camp Atterbury (Marshall and Prather 2003:121).

\section{Depression}

It is difficult to assess the Depression's impact on residents of Camp Atterbury. Certainly there was an impact, but, as previously noted crop production was not significantly reduced, although farm ownership dropped in the 1930s. Since the region was predominately agricultural, the people turned to their largely self-sufficient farms and were able to sustain life, but not necessarily prosper. Ruby Hibbs noted that "When the banks closed. ... most country people were better off than city people. Country people then had milk cows, feeder cattle, hogs, sheep, and chickens. Wool from the sheep provided some spring income. One dry goods store in Franklin bought wool from the farmers. ... Farmers then had gardens, orchards and berry patches. Many fruits and vegetables were canned for use in winter so there was always food on hand" (Hibbs 2007:39). Hibbs went further to describe Camp Atterbury's residents' self sufficiency. They substituted roasted wheat for coffee, made their own soap, cut their own wood, and baked their own bread just as they had done since their ancestors first settled the land.

While self sufficient, Camp Atterbury residents were cash poor. Many lost their savings when the banks failed. Hibbs describes one Fourth of J uly where several families wanted to make ice cream. They had all the ingredients, sugar, salt, cream, eggs, and milk, but no one had 25 cents to buy ice (Hibbs 2007:40). Some money could be made hunting and trapping or collecting bittersweet, walnuts, and persimmons (Bailey 1991:84). In some cases, farmers returned to the pioneer practice of bartering for the things they could not produce. 
Fruit grower Benjamin Douglas, of Brown County, wrote about the Depression in Brown County, including Hamblen Township. Douglas noted that Brown County natives were self-sufficient prior to the Depression and were self-sufficient during the Depression. "Comparatively few of our native population were on relief rolls. This was illustrated by the conditions in Hamblen Township, where ninety-two families were receiving help, and eighty-seven of them had moved into the county in the last three years. In other words, five native Brown County families had to be cared for. The others were 'foreigners'”' (Douglas 1936:80). These foreigners were people who moved to the county to "ride out the depression." "They had heard that it was easy to make a living here and simply moved in and occupied any old building they could find - and in Hamblen Township were many abandoned farms. We had a few such newcomers in my own neighborhood, but for the most part they occupied the areas "back of beyond," where thriftier people had found it hard going on rough land" (Douglas 1936:80). Despite the new arrivals, Brown County saw continued outmigration during the Depression; "At one time there was a sign in front of the courthouse that read 'Log cabins in any direction"' (Bailey 1991:77).

Perhaps some employment came to Brown County when the game preserve became Brown County State Park in 1928. In 1934, the Civilian Conservation Corps built picnic areas, cleared trails, put up buildings, barns, and an amphitheater at the park (Bailey 1991:83). In 1936, the Works Progress Administration enrolled 500 unemployed men in Brown County. They assisted the Conservation Corps men, built the first high school gym in the county, and constructed a courthouse annex (Bailey 1991:84-85). Another government Depression program was the Bean Blossom Land Utilization Project. This was a resettlement project, but families from Hamblen Township were not included as far as is known (Bailey 1991:85) (Figure 49). This resettlement project indicates that not all of Brown County was as well off as Douglas described in the preceding paragraph.

\section{The Army arrives}

On 6 J anuary 1942, after a year of rumors and newspaper articles threatening local families that they might lose their farms to the Army, the War Department announced that the U.S. Army would purchase some 40,000 acres of Bartholomew, J ohnson, and Brown Counties just west of Edinburgh, IN for a 30,000 man camp (Brown et al. 1981). By April of that same year, 15,000 workers began constructing the cantonment area even while negotiations with land owners continued. 


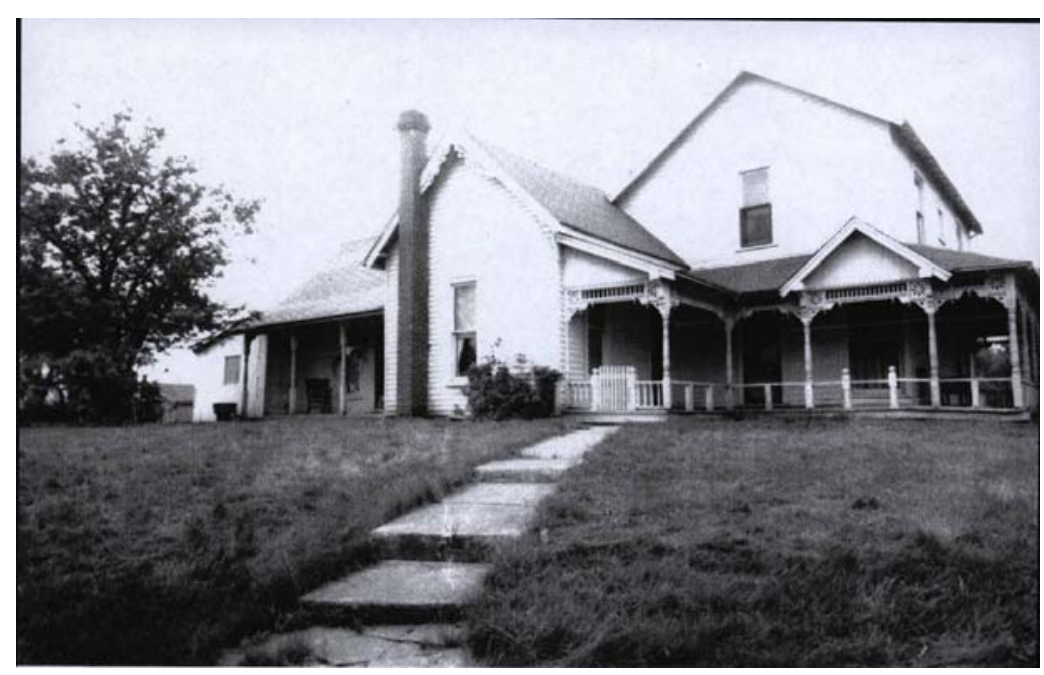

Figure 49. George and Alice Stillabower home circa 1942 (courtesy Camp Atterbury Museum).

For the farmers of Camp Atterbury, the swiftness with which their farms were purchased must have been shocking. The Army's interest in the area began in J anuary 1941. At that time the War Department was looking for a suitable area for a large Midwestern post (Arbuckle 1952). A newspaper article on 8 May 1941 announced that Bartholomew County might be the target for the Army camp (Brown County Genealogical Society 2006). Only a week later, surveyors arrived and surveyed land northwest of Columbus using local people to assist.

The location of the camp was clearly a landscape choice. Charles Hurd, camp architect and engineer, described its advantages. The area was close to Indianapolis, had good rail and road connections, was in an area of light population where much of the land was "untillable," and the cost per acre was low (Hurd 1941:14). One member of the Site Selection Committee, Senator Happy Chandler, stated that the town of Edinburgh, just east of the proposed location, was within a 300 mile radius of 60 percent of the population of America. It also had excellent transportation infrastructure and water sources (Stott 1984:9). The location also had the advantage of low cost acreage to the west (Brown County) and south (Harrison Township) in case the proposed camp needed to expand at a later date (Hurd 1941:14). The only point of concern about the location was which of two tracts, a northern or southern tract, was best for the Army. The differences between the two overlapping tracts were minor. Hurd recommended the northern tract, which included more of J ohnson County, because it included a larger flat area that would require less cut and fill for cantonment construction (Hurd 1941:14). Some 700 families were expected to be affected (Arbuckle 1952). 
The 7 December 1941 attack on Pearl Harbor removed any doubt that the Army was going to build a camp in Bartholomew County. On $14 \mathrm{~J}$ anuary 1942 landowner negotiations began, accelerated by the Army's condemnation of the land filed on J anuary 24. The condemnation took the first 7271 acres, mostly in J ohnson County, and required the landowners to move by February 14 (Arbuckle 1952). Some landowners, resigned to their loss, signed an option and left. Others refused, hoping for increased prices for their land (Figures 49 [p 113] and 50). Those that refused became defendants in the condemnation procedures. Not to be delayed, on 4 April 1942, the government moved to take the land, pending the outcome of the suit. Cases were settled as much as a year later in Indianapolis courts. Overall, the juries favored the government and residents got less for their land than they wanted. Mrs. Louisa Prichard, who signed the option, received the first check on 6 March 1942 (Arbuckle 1952). In Brown County, Mary I. Stillabower ( $\$ 400.00$ for 19 acres) and Clarence Wenger ( $\$ 1,600.00$ for 78 acres) were among the first to receive checks for their property (Brown County Genealogical Society 2006).

As construction continued, landowners of the remaining land waited their fate. Some residents on the fringes of the camp were told they would have to move and then told later told their land would not be purchased. Others were told they were safe, but later the Army condemned their land. Eventually, the Army occupied 40,351 acres; 10,398 in J ohnson County, 25,908 in Bartholomew, and 4045 in Brown County (Arbuckle 1952). The price per acre ranged from $\$ 5.00$ per acre to as much as $\$ 200.00$ an acre, according to one source (Brown County Genealogical Society 2006), and the average per acre was $\$ 94$ dollars (Arbuckle 1952).

However, former residents who were interviewed about the acquisition never heard anyone getting as much as \$200.00 an acre (Mead in Taulman and Welsh 1999:14). "There wasn't anyone who got enough money for their land. They couldn't buy a farm equal to what they had to give up" (Maurice Nichols in Taulman and Welsh 1999:14). To add to the landowners' frustrations, the Army allowed them to take their furniture, but would not let them move their home appliances or remove farm improvements (fencing, etc.). If the landowner could not find a truck to rent, they had to leave their furniture behind. One farmer, who had a small sawmill on his land, had to leave behind his pile of sawed cherry lumber, which was later burned by the Army. 


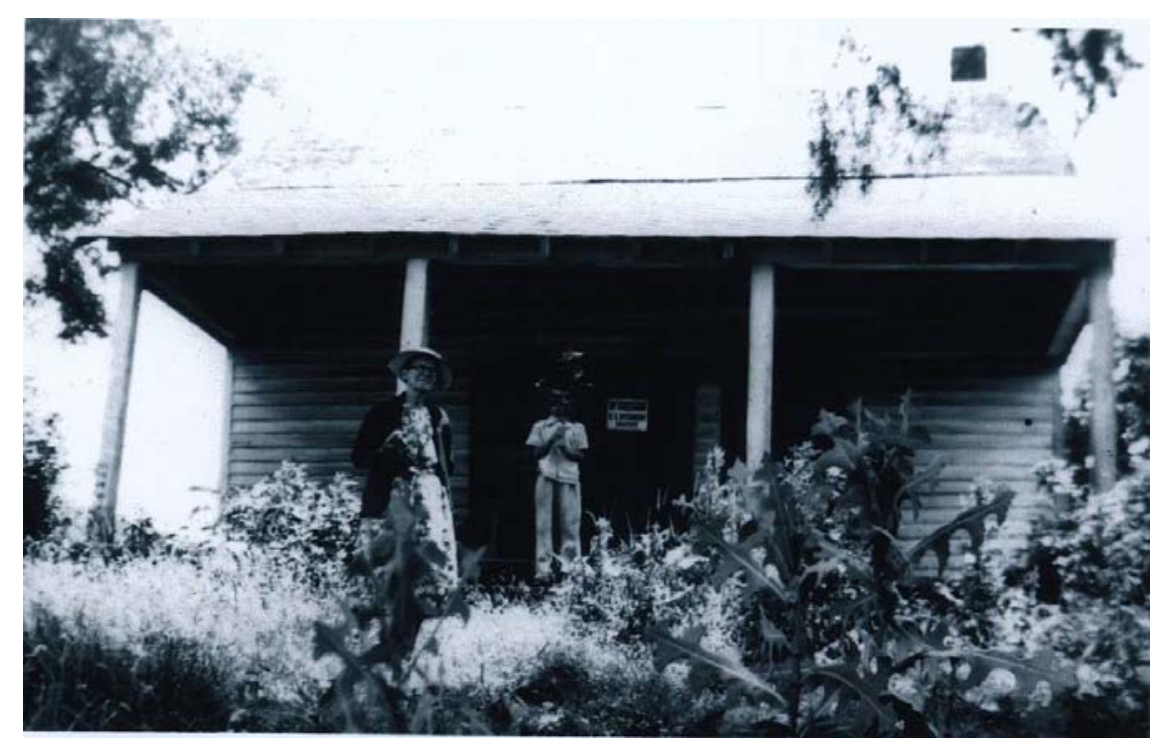

Figure 50. Emily Long stands in front of her home after Camp Atterbury acquisition. Sign on door reads "No Trespassing, U.S. Government Property" (courtesy Camp Atterbury Museum).

Apparently, the Army had plans at one time to auction off the houses after the original landowners left and that is the reason they insisted that house appliances be left behind. Most houses were bulldozed, burned or destroyed by tanks. However, at least one house was auctioned and moved (see Mead in Taulman and Wertz 1999:58-67) and others may have been as well.

The total number of property tracts taken was either 643 or 637, of which 402 were direct purchases from landowners. The remaining tracts consisted of lands condemned by the Army or that had defective land titles (Arbuckle 1952; Letter to Arbuckle, July 1946). A typed manuscript in the Bartholomew County Historical Vertical Files provided a further breakdown of the acreage and lots. The accuracy of this material is not known. For instance, it had a total of only 547 tracts listed as follows: 344 in Bartholomew plus 14 in Kansas town, 30 tracts of churches, schools, and cemeteries; five tracts in Brown County; and, 154 tracts in J ohnson County. For Nineveh Township, Bartholomew County, it noted that 13,500 acres were acquired at an average assessment of $\$ 55.90$ an acre. Union Township lost 10,720 acres with an average assessment of $\$ 16.50$ an acre. Harrison Township lost 1235 acres at \$19.60 an acre and German Township lost 325 acres at \$88.85 an acre (BaCHS Vertical Files, Camp Atterbury).

Besides farms, there were 28 cemeteries (Camp Atterbury Records, 2009). J ohnson County cemeteries included Pisgah Christian (or Methodist) 
Church, Knapp Cemetery (on Route 252), Harriett Creek Cemetery, and two family burial grounds (Waltz in Taulman and Wertz 1999:35). Bartholomew County cemeteries included three in Union Township (St. John's Lutheran, Bethel Methodist, and Ohio Ridge), three in Nineveh (Kansas Methodist, Garrison, and Long), and two in Harrison Township (Mt. Olive and Mt. Carmel) (Arbuckle 1952). According to Arbuckle, the Kansas cemetery burials were not removed, nor were those in one of the private cemeteries. In Brown County, the Christian Bethel Church Cemetery (Mt. Moriah) and a private cemetery were not disturbed either. Today, Tom J ones, Bocock, Powell, Waltz, an unnamed cemetery, Kansas, Mt. Moriah, Wilder, Anderson, and Stone Arch cemeteries remain in Camp Atterbury and are maintained by the U.S. Army. The others were removed to a new burial ground on the Nate Wells farm in Blue River Township. The camp closed the Kansas, Records, and Renner schools in Nineveh Township, Bartholomew County, and the Precinct and Lowell schools in Union Township. In Brown County, the New Bethel Christian Church near Mt. Moriah moved (Brown County Genealogical Society 2006).

Besides the shock of losing their homes and the anger at not getting what they considered a fair price for their land, the residents lost their sense of place and past. Inez Stott lamented that "The sad thing about it is that they not only took our land, but they also took our heritage and hopes for the future" (Stott in Taulman and Wertz 1999:61). Mrs. Gusta Hants, who worked at the J ohnson County Courthouse stated, “I'd see people come in crying all the time, and let me tell you, it was an awful sight. These people lost their homes and had to go out and buy land at $\$ 300$ or $\$ 400$ an acre after they got \$100 an acre" (Hants in Taulman and Wertz 1999:14). Newspaper articles painted a different picture. A 1941 newspaper stated that Kansas' residents "are not bitter, nor do they plan a great hullabaloo of protest against the proposed camp. They're just sorry it had to strike here" (Fifer 1941).

Time has softened some of the anger. Another newspaper article, about a reunion of landowners noted that at the time, "Some of the people were bitter about having to pull up stakes and move out" and some fought the government for a better price, but at the reunion, "Atterbury residents didn't seem bitter about the past” (Madsen n.d.). Another resident, Emerson Coy interviewed many years afterward, "I don't hold grudges anymore, because it was something that had to be done" (Coy in Taulman and Wertz 1999:63). 
There were some positive outcomes. Some residents were able to obtain employment with the camp. Herman J ohnson, whose homestead was taken by the acquisition, moved across the street, off the camp grounds, and found a job driving a truck for the Army. He kept that job until retirement (Personal communication, Mr. Herman J ohnson, 7J une 2009). Assuming the history of camp construction is similar to other camps built during the WWII, locals were hired for the construction, and businesses in Columbus, Edinburgh and Franklin thrived from business with the troops after nearly 10 years of depression.

\section{Summary}

The period between 1920 and 1940 was marked by a national economic crisis, which hit the agricultural sector early in the 1920s and the rest of the country around 1930. Throughout this period, Camp Atterbury remained a rural agricultural community. The community suffered from the economic hard times, but was able to survive. Written records appear to indicate that Bartholomew and J ohnson County farmers were relatively better off than their urban neighbors.

Rural life in Brown County at this time was different. A Works Progress Guide to the state described Brown County around Gnaw Bone, south of Camp Atterbury:

The settlements in this region are poor and sparse and the land sterile and hilly, yet agriculture is the principal occupation, and corn grows on the narrow strips of bottom land. ... Log cabins are still numerous, and nearly every house is heated by wood-burning stoves or fireplaces, and lighted by coal oil lamps. Slopes in this area are too steep for cultivation, and the region is jumbled and heavily foliaged wilderness of hills and valleys (American Guide Series 1941:356).

Brown County farmers suffered more than their Bartholomew and J ohnson County neighbors (Figure 51). A number of them abandoned their farms in the 1920s and some of these farms were reoccupied by families fleeing the city life to return to the land and survive the Depression by subsistence farming. Long time residents saw their quiet hilly landscape being invaded seasonably by tourists. Some embraced the opportunity, while others resisted and resented the tourist's presence. 


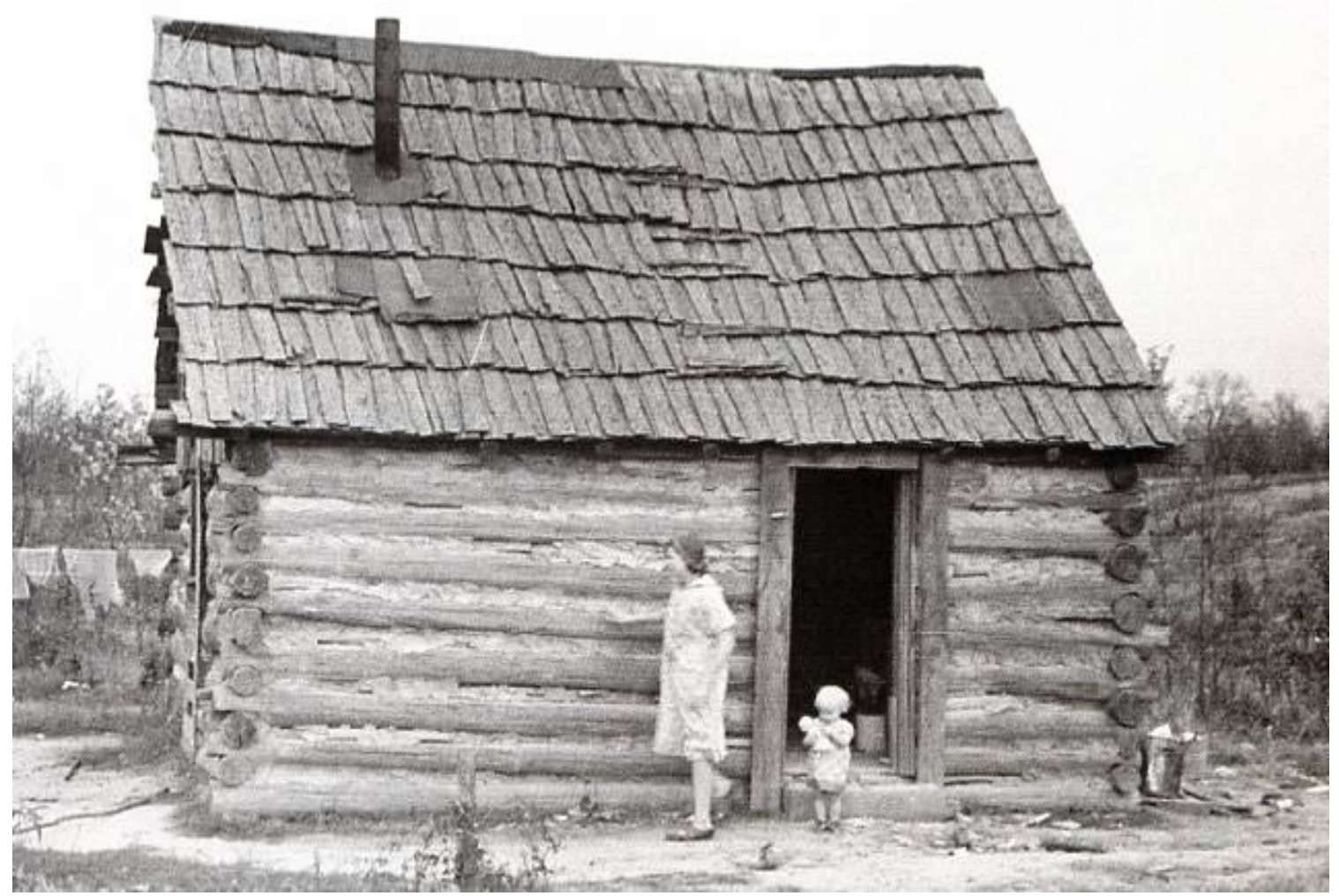

Figure 51. An example of a home in Brown County, during the Depression, depicting the contrast between Camp Atterbury residents and those in extreme poverty. These people were resettled (courtesy Reid 1987:3). 


\section{Landscape, Context, and Management for Historic Period Sites at Camp Atterbury}

\section{Introduction}

The value of an archaeological resource is in its potential to reveal information about the past. To evaluate historic sites at Camp Atterbury for their eligibility for listing in the National Register, and then to manage them in compliance with Federal and U.S. Army-National Guard Bureau standards, they must be evaluated within the context of their history and the research that will reveal that past. The previous chapters outlined the settlement history of Camp Atterbury. This chapter examines, organizes, and evaluates the known and expected historic sites at Camp Atterbury against that landscape history. The result is a historic context, defined as a "unifying framework" (National Park Service 1991:11) that will allow cultural resource managers at Camp Atterbury to evaluate specific archaeological sites already known and those unknown resources discovered as a result of future surveys. Furthermore, this chapter will suggest research topics that may be examined should compliance regulations require data recovery as a result of adverse impacts to identified historic sites.

\section{Summary of the settlement history}

Four generalized landscapes described in the previous chapters characterize development and change in the Camp Atterbury region. These four landscapes are:

1. The Initial Landscape

2. The Pioneer Landscape

3. The Late $19^{\text {th }}$ Century Landscape

4. The $20^{\text {th }}$ Century Landscape.

Clearly these chapters have described a rural agricultural based life of steadily increasing prosperity and peace, a microcosm of life in what has been called "corn belt culture" (Power 1953).

The Initial Landscape: The earliest European and American settlers found a heavily timbered, well-watered landscape, largely vacant of human occupation. Abundant wild food resources allowed settlers to sustain life until they cleared the land for agriculture. Indeed, that abundance may have 
been so great that a hunting-gathering lifestyle could have been sustained longer than it did. To the new settlers, the fertile soils of the Tipton Plain practically demanded crop production. Even the unglaciated areas of Camp Atterbury provided enough hunting resources for the first settlers to sustain a particular subsistence lifestyle typical of the southern states or Upland South. The following paragraphs describe this lifestyle in detail. Overall, the initial landscape was wild and dangerous, but an agricultural Eden compared to the overpopulated European continent that the pioneers' ancestors fled a few generations before settling in Indiana.

The Pioneer Landscape: The 1819 “New Purchase” officially removed Native Americans from the Bartholomew, J ohnson, Brown County region and land acquisition proceeded quickly. The land may or may not have been settled quickly-historical sources seem to be divided on that point-but it was purchased quickly. Early land acquisition maps indicate the land had pretty muchbeen "bought up," if not settled, by 1830. Over the next 40 years, the settlers made steady progress toward establishing a rural agricultural community.

The landscape influenced the pioneer development of the Camp Atterbury community in many ways. The rivers - the Driftwood, Sugar Creek, Blue River-were the earliest transportation and entry routes to Camp Atterbury. From the rivers, the pioneers built footpaths and roads alongside leading into the interior regions. The rivers also determined the location of the earliest mills and towns. Millers were usually entrepreneurs and once the mill was built, they also built a store, or someone else came along and built a store or blacksmith shop nearby. These places soon grew into the market towns of the 19th century including Columbus, Edinburgh, Franklin, and Taylorsville. Churches and schools were built at the same time, but they were more dispersed across the landscape. Determining the location of a county seat had a landscape and political aspect. The courthouse needed to be centrally located to serve county residents, but speculation determined the exact location of all three county seats around Camp Atterbury. Speculators donated the land to draw people to the vicinity of their land to ensure their future wealth.

Once central places like Columbus, Edinburgh, and Franklin were established along the major transportation routes, there really was no further dramatic landscape or social change for quite sometime. From the main roads, the pioneers built branch roads that were primarily along township and section lines to get goods to the markets. The landscape dictated that 
people in the Camp Atterbury region turned largely to the east along the Driftwood River, The East Fork of the White River, Blue River, Sugar Creek, and Mauxferry Road for supplies, milling, and transporting crops to market. The rolling hills of Brown County deterred the flow of goods and services westward.

Subsistence level farming was typical during the early part of the pioneer period, but the fertile soils allowed most farmers to quickly increase their production. By the 1830s, they usually had a surplus crop for market. Corn became the most profitable crop and, by exploiting this crop along with wild running hogs, many farmers enjoyed economic success up until the Civil War. Farm houses were visible indicators of this success. The pioneers constructed their first farmhouses using log construction. Beginning in the late 1830s, the wealthier farmers turned to balloon frame construction. By the end of the pioneer period brick houses appeared across the Tipton plain.

The Civil War threatened to disrupt this pioneer community. No doubt the loss of sons and fathers did just that, but the community was never in serious jeopardy, even if there was disagreement and dissention in the rolling hills of Southern Indiana, including Brown County.

The Late $19^{\text {th }}$ Century Landscape: The period after the Civil War began with steady agricultural improvement and prosperity for most residents of Camp Atterbury. For those living on the Tipton Plain, the land continued to be fertile for corn and wheat production. The landscape on the Tipton Plain and Hog Bottom areas began to resemble the rural community seen today, but with larger woodlots. The landscape consisted of dispersed farmsteads, with large brick homes and numerous outbuildings, and large barns. Some farmers broke their land into smaller parcels at this time, due to inheritance practices of dividing land among ones children upon death. The farms on the plain not only had rich soils, they had abundant timber so each farm had a large woodlot for constructing outbuildings and for burning to keep warm during the winter. Fields and woodlots alternated across the landscape. As time progressed, the fields were lined with barbed wire along the roads. Corn as a cash crop and as a way of life (i.e., seasonal rituals) increasingly became entrenched among the residents. As World War I increased demand for their corn, Camp Atterbury residents became increasingly linked to the wider world economic market. Churches and schools, however, still provided the local community glue. Secret societies, fraternal organizations, agricultural organizations, and political parties 
both strengthened community ties while creating social strata within the community.

The residents of the hill area of Brown and Bartholomew County also enjoyed improvements at the beginning of the late $19^{\text {th }}$ century, but their farms remained small and self-sufficient, sometimes at a merely subsistence level. There simply was not enough fertile soil in the uplands to allow large fields of corn like those along the Tipton Plain. The farmsteads also remained smaller than those of the Tipton Plain. Some farmers retained log construction techniques rather than changing to frame construction. During this period, an economic and perhaps social divergence began to appear within Camp Atterbury. The farmers in the Brown County hills remained subsistence farmers while the farmers of the Tipton Plain diversified their crops and found greater economic success.

In the 1880s, the landscape of Brown County began to change even more dramatically. The national demand for timber was insatiable, especially for hardwood, and Brown County residents found that they could meet that demand. Also, lumber barons moved in, purchased the cheap land, and began cutting timber. After 20 years, the barons moved on, leaving the hills with large open areas. Soil erosion took what was left of the topsoils making the land even less usable for farming.

The isolation experienced by pioneer settlers due to poor roads no longer was a problem by the end of this period. Dirt roads were still the norm in rural areas, but there were plank and gravel roads near the towns. As a result, travel to town took less time. Wealthy Tipton Plain farmers were using steam driven threshing machines on large farms in the late 19th century and purchasing new automobiles in the $20^{\text {th }}$ century. Families with automobiles drove to Franklin, Edinburgh, or Columbus on Saturdays, and caught the interurban to Indianapolis. Road improvements and the rapid transition from horse to automobile actually served to keep Camp Atterbury as a rural landscape of dispersed and well developed farms. Since the larger towns were easily accessible, smaller hamlets like Kansas were less critical to the rural residents.

The 20th Century Landscape: 1920 to 1940: The 1920s changed the lives of all the residents of Camp Atterbury. Many people experienced decreasing wealth and a return to subsistence living between 1920 and 1940. While the national market crashed in 1929, the agricultural market crashed much earlier than that, perhaps as early as 1922. Through the 
1920s, agricultural prices and markets dropped, while yields held steady or even increased due to new farm practices including the use of fertilizers and gasoline-powered farm equipment. However, farmers realized that while they were working harder and producing more, they were getting less return for their labor. Many farmers found new markets in tomatoes or canning vegetables, but corn and hogs remained king. It is not known exactly how the Depression affected those Camp Atterbury residents in the J ohnson County and plains areas of Bartholomew County. Certainly, diversification eased the effects of the economic downturn. Camp Atterbury farmers had been self sufficient since pioneer days. The people had no money, but it does not appear that starvation was a threat, as it was in urban areas.

Twentieth century life in Brown County appears to have been more difficult than in the Bartholomew and J ohnson County region. It is not known if this difficulty applies to Camp Atterbury. Brief interviews conducted during the 2009 settlers reunion indicates that the residents of Camp Atterbury were not as desperate as those residents in Brown County that had to be resettled. In the resettlement areas, farms that had been abandoned were reoccupied by outsiders from large cities attempting to survive the Depression by returning to subsistence farming. However, when war threatened, the Army was not looking for a densely populated, highly fertile, expensive landscape to build a camp. The Army was interested in cheap land with a thin, dispersed population, so that it would not have to displace too many people. The landscape that became Camp Atterbury suited the Army.

There were two distinct landscapes at Camp Atterbury at the time of the Army's acquisition. The rolling hills area contained small farms, a few orchards, and subsistence farmers. The hills were tree covered, but with thin hardwoods and few areas had virgin timber. Many homes were still constructed of horizontal log construction. On the plain, the farms were open, with cultivated fields and small woodlots. Farm buildings were brick or frame, and outbuildings included large barns, grain storage tanks, or elevators, and there was usually a car or car and truck parked nearby. Fields were all enclosed by barbed wire. Branch roads were still dirt, but main roads were gravel and wide. Some roads were paved with asphalt. Churches and schools were scattered across the landscape between the farms, usually at the corner of four section line crossroads. Farmers took their produce to county markets and took their cash crops to the grain elevator along the railroad track. The landscape at this time was not much 
different than that seen today in J ohnson and Bartholomew Counties. In 1942, the U.S. Army came and ended the rural agricultural landscape at Camp Atterbury.

\section{Historic context: becoming Hoosiers at the margin of corn belt culture}

As the previous chapters have discussed, Camp Atterbury lies at the margin between two different geophysical landscapes. Toward the north is the Tipton Plain, and to the south is the unglaciated rolling hills of southern Indiana. The majority of the camp is in the unglaciated hills, while the rest is on the fringe between the hill county and the more distinctive prairielike flats of the Tipton Plain. At the time of U.S. Army acquisition, along the very northern border of Camp Atterbury, the camp included more of the Tipton Plain landscape. This is now under state ownership.

The flat Tipton Plain to the north of Camp Atterbury and the hills of southern Indiana not only are physically different, they generally attracted different American cultures. Northern Indiana was settled by New Englanders and Middle Atlantic peoples from Massachusetts, New York, and Pennsylvania. The southern hills of Indiana were settled by Upland South people from Kentucky, Tennessee, and Virginia, and also Pennsylvania. These different cultures brought distinctive ideas about settlement, government, lifestyles, and values, which should (or may) be reflected in the archaeological remains of Camp Atterbury's historic sites. The historical data presented from previous chapters indicate that the stronger influence was Upland South culture, but, according to historian Richard Power:

The vernacular architectures of Virginia-Kentucky and New England met about midway in Illinois, with the old National Road through Terre Haute, Vandalia, and St. Louis dividing them. We are free to suppose there was a belt of overlapping where each style influenced the other" (Power 1953:138). Power's supposition provides a starting point for understanding the Camp Atterbury region. Even though Power was discussing specifically architecture, the concept is broader and Camp Atterbury is that place - the belt of overlapping. At Camp Atterbury, the Upland South pioneer met Mid-Atlantic and Northeastern New Englanders and together they became Midwesterners. Power further states, "Neither strain [Upland South or New Englander] won out by subordination of the other, but both were conquered as it were by the region itself, were taken by the hand by a process of blending, in which the final outcome was neither Yankee nor Southern, but 'Western'”' (Power 1953:174). 
Based on the previous chapters, this process of blending, or "becoming Midwestern," appears to be an overarching theme or historic context that can be used to guide the evaluation process of historic sites at Camp Atterbury. It is proposed that the archaeological resources at Camp Atterbury offer the opportunity to examine the archaeological manifestations of two closely related, yet distinctive cultures, and how they blended to become Midwestern. Therefore, the proposed Historic Context for Camp Atterbury is: Becoming Hoosiers, at the Margin of Corn Belt Culture.

\section{The traditional upland south}

Upland South culture has a long tradition in the academic literature. The "Upland South" was originally defined by cultural Geographer Fred Kniffen (1965), but numerous cultural geographers described it (Clendenen 1973; Glassie 1968; J ordan and Kaups 1989; Meyer 1975; Newton 1971, 1974; Otto and Anderson 1982; Otto 1985). Archaeologists have found this cultural tradition to be a useful one for research on small southern yeoman farmsteads in regions along the Tombigbee River (Adams et al. 1981; Futato 1989; Smith et al. 1982), northeast Texas (J urney and Moir 1987), Arkansas (Sabo 1990; Stewart-Abernathy 1986), Missouri (Smith 1993), North Carolina (Stine 1989) and South Carolina (J oseph et al. 1991; Resnick 1988). The Upland South defines both the cultural tradition of the white, yeoman, farmer-hunter-stockman, plain folk and their geographical area of settlement in the upland South and southern portions of the northern states, including southern Brown County. Regional variations on the term include Upcountry, Upper South, and the backcountry, especially along the Appalachian chain (Fischer 1989; Ford 1986; J ordan and Kaups 1989; Otto and Anderson 1982: 89). Anthropologists have even recognized the distinctive traits of the Scots-Irish southern farmer as part of the "hill south" (Arensberg 1955).

The Upland South defines a tradition and ideology originating among the Celtic and Welsh peoples that mixed with German and English influences who migrated to America and initially settled in the Delaware Valley in western Virginia (Newton 1971), (J ordan and Kaups 1989), as early as the 1670s. Blending with the Chesapeake Tidewater, German and English traditions of southern Pennsylvania, this multicultural amalgamation resulted in "... an independent small farm owner/ operator who relied on traditional solutions to everyday problems which affected their economic, social, and settlement systems" (Smith et al. 1982: 9). These highly individualistic peoples rapidly migrated down the Appalachian chain beginning as early as the 1720s and after the Revolution, spread westward 
through the Cumberland and other gaps into Kentucky, Tennessee, and then north into Indiana and Illinois and later into Missouri. Farther south, they traveled across upper Georgia through upper Alabama, Mississippi, Arkansas, Louisiana, and Texas, and the Missouri Ozarks (Glassie 1968: 235; Kniffen 1965; Newton 1974; Meyer 1975). The land they settled was remarkably similar-mountainous or rolling and forested with plentiful game and marginal agricultural soils, like those of Brown County.

Milton Newton believed that these people were "preadapted" (Newton 1974) for the topography and climate found in the upper heartland of eastern America. Newton (1974: 152) defines preadaptation as "a set of traits possessed by a particular human society or part of that society giving that group competitive advantage in occupying a new environment." Newton listed several settlement and social patterns that define the Upland South. These patterns will be summarized below. Otto and Anderson (1982: 91) support this view and argue that "this woodlands-adapted agriculture of the plain folk permitted them to occupy the vast Southern forests in only two to three generations in the period between 1790 and 1840" (Otto and Anderson 1982: 91).

Upland South people lacked the capital and labor resources of the planter, but the abundant woodlands offered easily obtained building materials, subsistence hunting and grazing land for hogs. J ordan and Kaups (1989) contend that the many Upland South traits normally ascribed to the Scotch-Irish were originally northern European (Finnish) and Native American. "Our main thesis, to be defended in ecological, diffusionary terms ..., is that American backwoods culture had significant northern European roots" (J ordan and Kaups 1989: 35). Further, "In our view, the role of the Celts in frontier America has traditionally been greatly overstated, the Indian influence consistently underestimated, and the Finnish contribution almost wholly ignored or, without adequate scholarly evidence, dismissed." (J ordan and Kaups 1989: 37). Their argument was not that northern Europeans settled in America themselves, but that the Celts were the cultural carriers of such traits as building traditions borrowed from early Swedish-Finnish settlement along the Delaware River in the late 1600s. Importantly, they do not dispute that the carriers of these traits were the poor white Protestant yeoman who served as the "economic foot soldiers" in a surge of migration of Europeans to the southeast (J ohnson 1991: 220). 
The northern border of the Upland South has been seen as generally along the I-70, national road line (Anderson and Smith 2003:531), but more specifically, it should be along the margin between the Tipton Plain and unglaciated hills, right within Camp Atterbury. North of this line, the land was initially occupied by a few southerners, but as one proceeded farther north, the land was occupied increasingly by Easterners. J ust north of the line, the land was a mix of southerners and Middle Atlantic States like Pennsylvania. To the north, the land was occupied by New Englanders. A few of these New Englanders even settled the Camp Atterbury region. Still, Richard Power has noted that the southern Upland South people arrived first in the Northwestern Territory, including Bartholomew, J ohnson, and Brown County region. "Taking a long-time view, one might summarize the earlier settlement of the Old Northwest in this way: the Southerners had at least forty years' start" (Power 1953:1). Furthermore:

They had by 1830 planted their modes of living in the then settled portions of the Northwest-their farmways and speech, their educational and religious views, their dietary and cookery, ways of conducting business and politics, their homeways, social life, and amusements" (Power 1953:1). Easterners came second and quickly overcame Upland South peoples north of the hills line. By 1840, New Englanders and the Mid- Atlantic states were entering Indiana along the National Road, some heading south and blending with southerners. Likewise, they were using the Ohio River as a natural flow southward, and then northward into Indiana (Lewis 1990:81).

\section{Mid-Atlantic and New England tradition}

The Mid-Atlantic tradition has had much less attention in the literature and is more difficult to define. However, although both the Upland South and Mid-Atlantic traditions share a cultural hearth in the Delaware Valley and southern Pennsylvania, from there these traditions split. Mid-Atlantic people originated with English roots, but also with stronger strains of German and Swiss "pietists" from the upper Rhine (Lewis 1990:88). These people arrived in America around Philadelphia, but quickly migrated west and settled on fertile western Pennsylvania soils. They became successful farmers, and sometimes are referred to as Pennsylvania Dutch. Lewis noted that "...the promise of Pennsylvania was a portent of America's promise - a place where they highest values were freedom, tolerance, and the ability to make money" (Lewis 1990:88). They were largely tolerant of religious differences. After the American Revolution, they too turned west for new lands. Migrating west, they came along the National Road or down 
the Ohio River. They arrived with notions of large farms and towns as central nodes of business and commerce (Lewis 1990:100-103). They would strongly contribute to the economic and community development of the Camp Atterbury region.

To the north, New Englanders pushed west along the Great Lakes. With them came a strain of Puritanism and a cultural ideology much different than that of the Upland South. New Englanders took religion, education, and government seriously and would bring these values with them (Lewis 1990:85). Farming was poor in New England so many turned to manufacturing and brought these skills with them. How many of these New Englanders came as far south as Camp Atterbury is unknown. Lewis tends to put them farther to the north (Lewis 1990:81), while Power notes that New Englanders, arriving in the 1840s, settled in the southern regions of Illinois and Indiana also (Power 1953:16). Undoubtedly, most New Englanders by-passed Indiana as "the southern element was so strong here" (Mathews in Power 1953:74), but the cultural influences brought by these New England immigrants migrated south. These cultural patterns provided a contrast to those of the Upland South and mixing with Upland South patterns became Midwestern. Power quotes an early historian who noted that the:

Virginian and the Yankee could no more remain a Virginian and a Yankee than their ancestors had remained Englishmen in Virginia or in Massachusetts. The West gripped them, changed their economy, modified their political institutions, affected deeply the form if not the substance of their religions, influenced their architecture (Wertenbaker in Power 1990:137).

Given that Upland South pioneers arrived first regionally, and probably arrived in greater number than Mid-Atlantic and New Englanders, one can expect that the earliest archaeological sites on Camp Atterbury exhibited primarily Upland South characteristics. Over time the settlement patterns, economic patterns, social and political patterns were modified and all became associated with Midwestern Corn Belt Culture. The following discussion summarizes Upland South and to a lesser extent, Mid-Atlantic/ New Englander characteristics, and then discusses historic sites at Camp Atterbury. Some research themes and questions are provided as a guide for future archaeological evaluation of Camp Atterbury sites. 


\section{Summary of the settlement history}

Upland South intersite settlement patterns include:

1. Adaptation to woodland regions with bountiful game and marginal agricultural lands (Otto and Anderson 1982)

2. Dispersed, kin-based settlement and hamlets

3. Low-density population (Futato 1989: 82; J ordan and Kaups 1989: 66; Newton 1974)

4. Dispersed, low onder, central place, or community service sites (general stores, grist mills, churches, schools) (Newton 1974: 151)

5. Courthouse-town and county system that gave focus to civil order (Newton 1974: 152; Zelinsky 1951: 173)

6. Domestic sites initially located on high ground, next to water and later along roads (Newton 1974: 151; Sabo 1990: 140-146; Smith et al. 1982: 239).

These patterns are certainly characteristic of the rolling hills of Brown County and Bartholomew County.

Dispersion is the most visible pattern of the Upland South settlement pattern. Farmsteads at Camp Atterbury were widely scattered across the landscape. A dispersed settlement pattern of central place locales (general stores, hamlets, churches, schools, post-stops) also accurately describes the Camp Atterbury region. Churches, schools, and villages like Kansas, Mt. Moriah, and Williamsburg/ Nineveh, were widely dispersed across the landscape from the pioneer period up to the arrival of the Army. Early on, mills drew additional services like blacksmiths and merchants, which became community central places. Meanwhile the larger towns were confined to the main transportation routes, first along the Driftwood, and later along the main north-south highway and railways. Schools, of course, were purposely distributed by legislation to serve as focal points for the children of the surrounding countryside. Church locations were not regulated. However, it is possible that their locations were influenced by school locations as a result of the use of schools as multi-purpose facilities in the pioneer period. This is why they are often close by and form a central place like Mt. Pisgah. Post offices began in peoples homes and the first postmasters names were used as place names (Woodruff's for instance), but were moved to the nearby locales like Williamsburg/ Nineveh.

Upland South researchers have pointed out that the courthouse-town central place system was characteristic of the Upland South. The county sys- 
tem became the maximum unit of settlement (Futato 1989:82; Sabo 1990: 143) and allowed a minimum number of people to represent both the elite and subordinate members of society (Newton 1974:340-341). However, this system is probably more likely to be the result of the imposition of orderliness by the Northwest Ordinance, influenced by New England and Mid-Atlantic cultural systems. It is expected that a detailed study of the Camp Atterbury roads would reveal that early roads followed ridgelines and creeks, and that slowly there was a transition to the orderly northsouth, range and township road system through the late $19^{\text {th }}$ and early $20^{\text {th }}$ centuries.

Upland South intrasite settlement patterns include: (1) hilltop farmsteads as a seemingly disordered cluster of buildings with barns and outbuildings arranged around the house in an "order determined by the owner's changing conceptions of convenience" (Newton 1974:151); (2) separate house and outbuildings (smokehouse, barns, cribs, pens, food storage buildings) (Weaver and Doster 1982:63) serving multiple functions (J urney and Moir 1987: 230; Smith et al. 1982: 10-11); (3) "house faces the probable path of human approach..." (Weaver and Doster 1982: 64); (4) with dwellings shaded by trees (Weaver and Doster 1982: 64); and, (5) fields and pastures irregularly arranged, often following topographic features (Hart 1977).

Many cultural geographers and archaeologists disagree with Newton that the farms are disordered, noting that the arrangement of buildings on the Upland South farmstead have a clear and patterned arrangement (Glassie 1975; Weaver and Doster 1982; Smith et al. 1982; J urney and Moir 1987). Outbuildings are arranged around the main dwelling with the well, privy, storage shed, chicken house, and smokehouse close to the dwelling and the large animal pens, barns, and equipment sheds beyond the central core (Weaver and Doster 1982: 63-64). Smith et al. (1982: 241) noted that this arrangement is often clearly defined by a road or alley between the inner and outer ring of buildings and have proposed a model of Upland South intrasite farmsteads in which the main house is centrally located on the highest ground, with a well in close proximity. Beyond the house a ring of outbuildings are found including smokehouse, chicken coop, privy, and storm cellars. A road or trash accumulation from sweeping often helped define this area from the outer ring of buildings that consists of animal pens, barns, and sheds. In the fields, occasional sheds also can be found.

One reason for the above arrangement, briefly mentioned by Smith et al. (1982: 241), is the sanitary drainage. Clearly the outer buildings, contain- 
ing large farm animals, need to be on a different drainage system than the dwellings. At Bay Springs, MS, this was accomplished by having the house on the highest ground or, at the least, on a separate drainage than the barns. With some differences based on the prairie landscape, J urney and Moir found similar patterns in Texas (J urney and Moir 1987: 234-236). A regional influence on the general location of barns may be the prevailing winds.

How closely these patterns fit the Camp Atterbury region is unknown. However, it is expected that these patterns are exhibited in the hills area, while, more ordered farms are seen in the J ohnson County Tipton Plain region. For instance, fields are probably neatly arranged and shaped by township and section roads. There should be local variations in building types and functions also, including below ground cellars, basements, and grain storage tanks/ elevators. Specialized buildings associated with dairy farming (an activity not common in the Upland South) and stock raising, usually have outbuildings associated with this activity, as opposed to, for instance, a tobacco barn in Kentucky. Other special function buildings should be expected.

Gregory Trewartha recorded regionalized characteristics of farms across America, and his results provide relevant data on the differences between "cotton belt" and "corn and livestock" farms (Trewartha 1948). Trewartha's study used high school students and a fill-in form to collect data for 641 farmsteads across the nation (the data from Indiana included 24 farms near Greensburg, IN). His cotton belt region included the southern portion of the Upland South, and his corn and livestock region included midIndiana, northern Missouri and southern Iowa (Trewartha 1948:22). For the purposes of the following discussion, the cotton belt represents Upland South patterns expected in Brown County and Bartholomew County hills, while the corn and livestock data represents the larger farms in the J ohnson County region of Camp Atterbury. Trewartha's data provides a foundation for examining Camp Atterbury's cultural milieu using its archaeologi$\mathrm{cal}$ sites. The data is from the late 1940s, but certainly has relevance for at least the first half of the $20^{\text {th }}$ century. Below were some of the more distinctive differences between "cotton" or Upland South farms and "corn and livestock," or Corn Belt farms that Trewartha recorded.

Trewartha found that 93 percent of cotton farmsteads were between 1 to 3 acres in size, while only 63 percent of Corn Belt farms were that small (Figure 52); indeed Corn Belt farmsteads were overall larger, as much as 
15 percent were over 5 acres in size (all data from Trewartha 1948). Most of both cotton and Corn Belt farms fronted the highway at 48 percent and 55 percent respectively, while 37 percent of cotton and 37 percent of Corn Belt farms were set back away from the road (Figure 53). The number of farm buildings on the farmstead was significantly different. Some 33 percent of cotton farms had four or fewer buildings, 50 percent of cotton farms had between five to eight buildings, and 17 percent over nine buildings (Figure 54). Meanwhile, only 7 percent of corn and livestock farms had four or fewer buildings, 45 percent had five to eight buildings, and as many as 44 percent of corn and livestock farms had nine or more buildings.
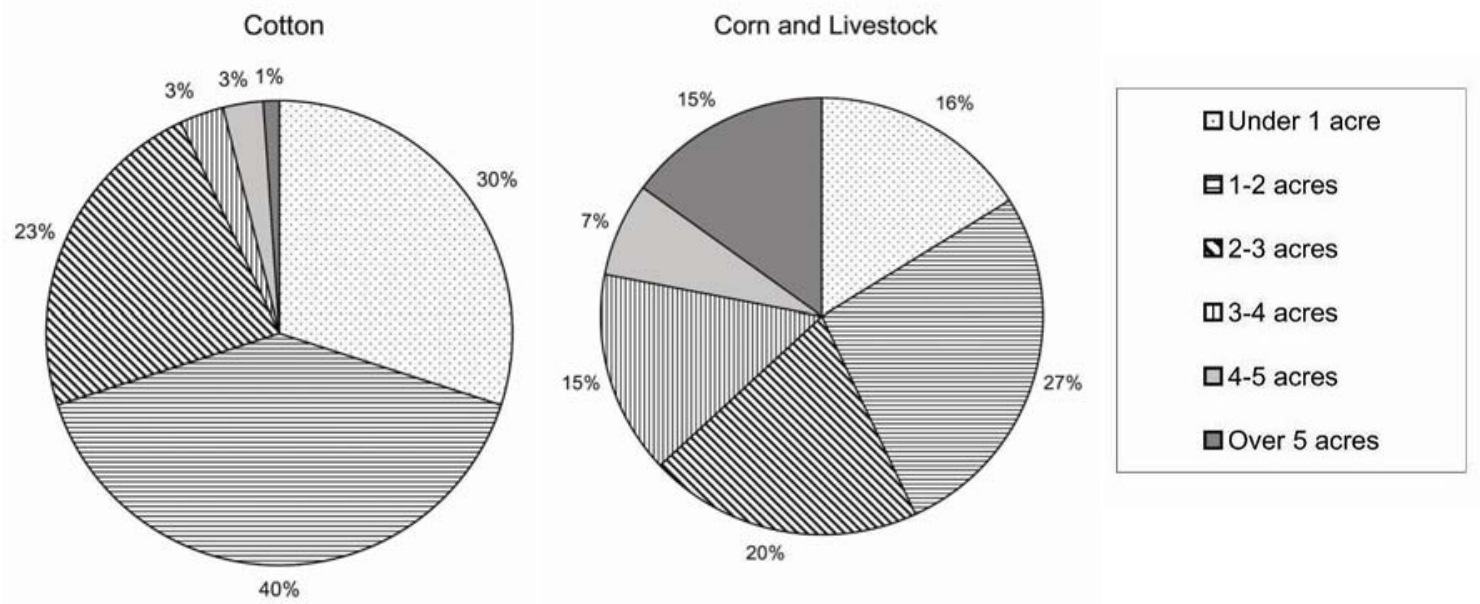

Figure 52. Area of farmstead (in percent).

Cotton

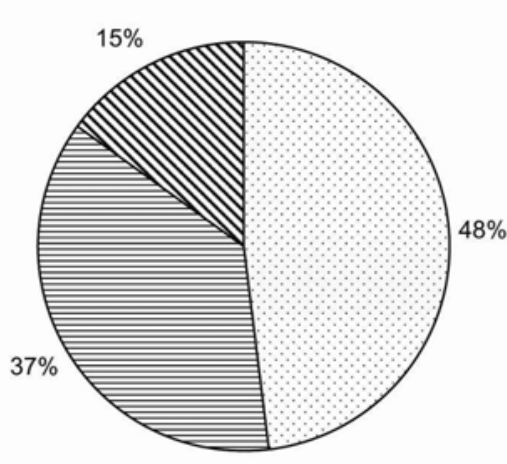

Corn and Livestock

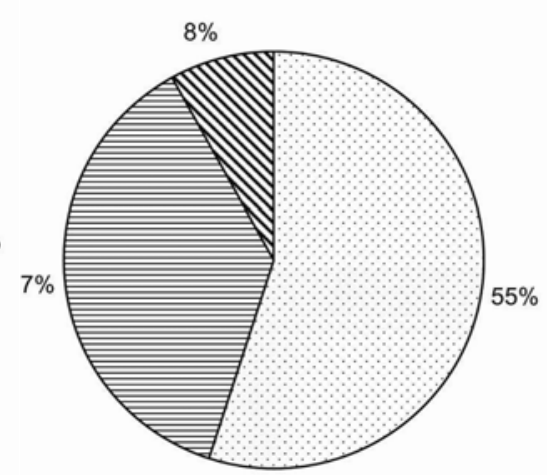

$\square$ Fronting on highway 日Set back from highway \$Divided by highway

Figure 53. Relationship of farmstead to a public highway (in percent). 
Cotton

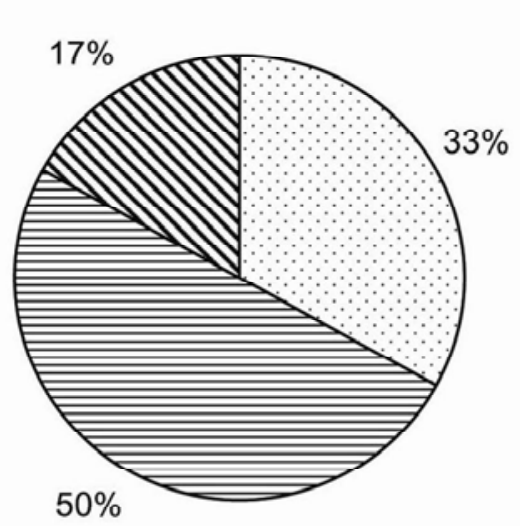

Corn and Livestock

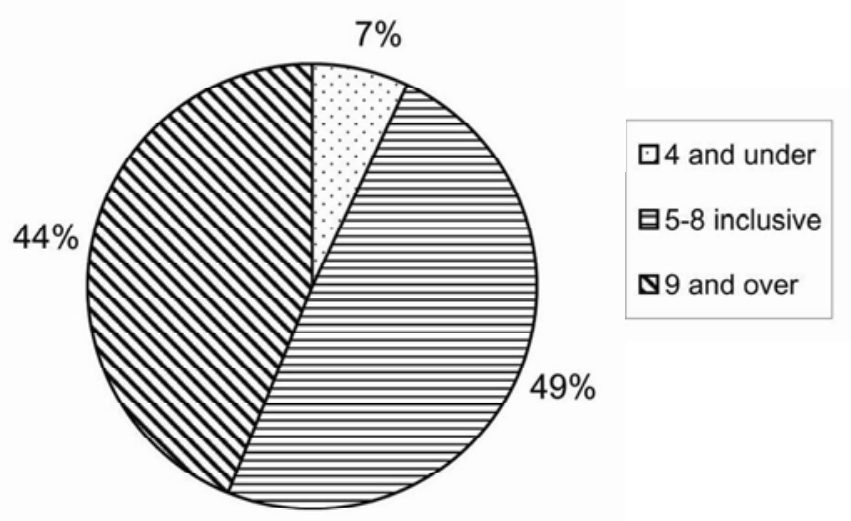

Figure 54. Number of separate buildings on farmstead (in percent).

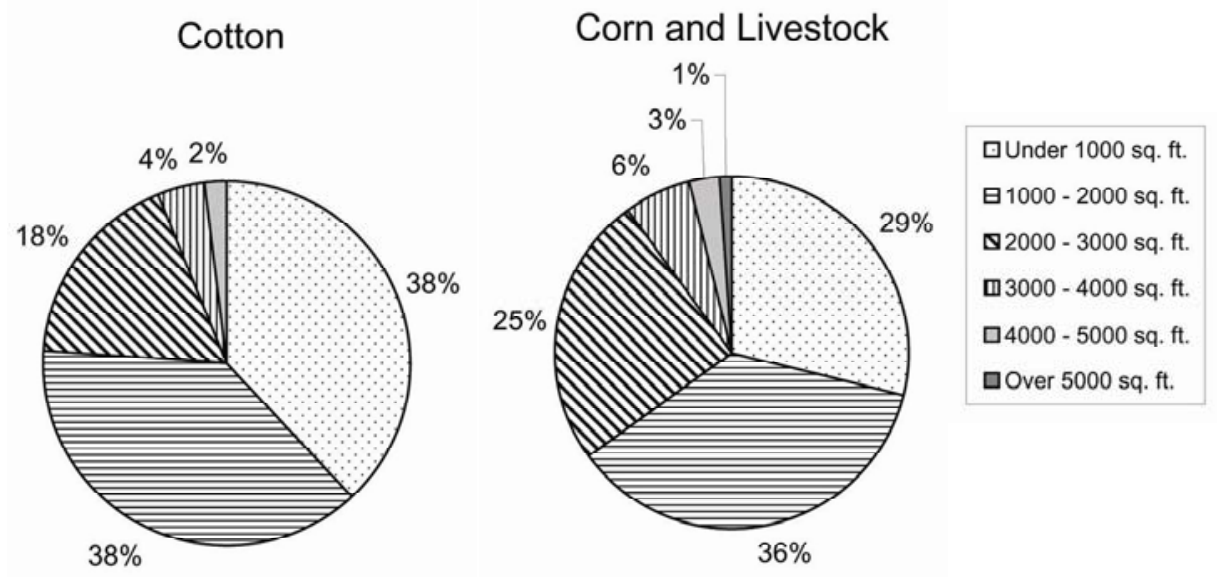

Figure 55. Barn size (in percent).

The difference in the types of buildings was also dramatic in Trewartha's study. Garages were found on 37 percent of cotton farms, but were on 70 percent of corn and livestock farms. Barns on cotton farms were generally smaller than corn and livestock farms (Figure 55). Some 38 percent of cotton barns were less than $1000 \mathrm{sq} \mathrm{ft}, 38$ percent were between 1000$2000 \mathrm{sq} \mathrm{ft}$, while 29 percent of corn and livestock barns were $1000 \mathrm{sq} \mathrm{ft}$ and 36 percent were between 1000 to $2000 \mathrm{sq} \mathrm{ft}$. Only 18 percent of cotton region barns were over $2000 \mathrm{sq} \mathrm{ft}$, while 25 percent of corn and livestock barns were that large. Some 81 percent of the cotton barns were unpainted, while only 24 percent of corn and livestock barns were unpainted (Figure 56). 
Cotton Corn and Livestock
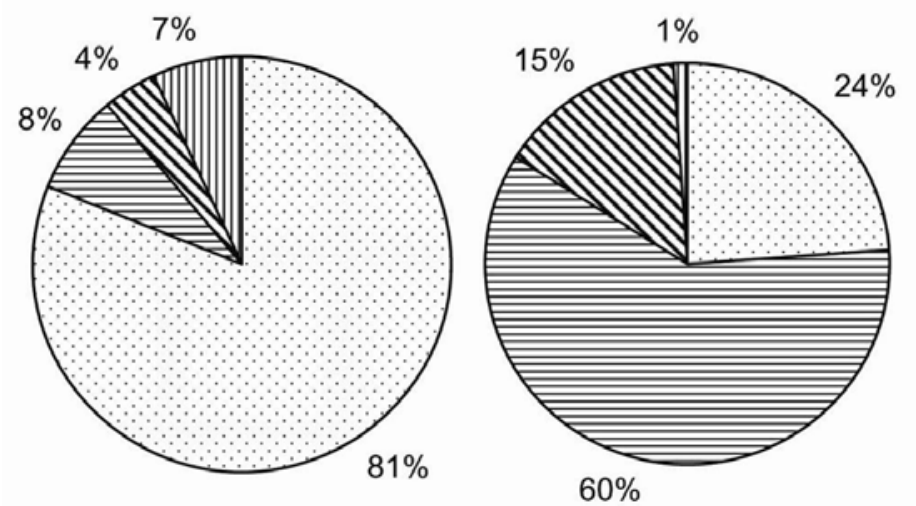

๑Unpainted

日Red

$\Delta$ White or gray

mOther colors

Figure 56. Barn color (in percent).

Cotton

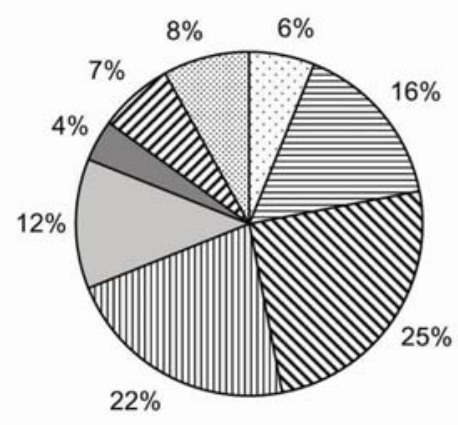

Corn and Livestock

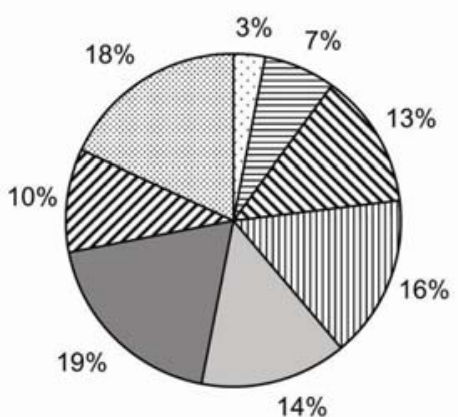

घ3 rooms

日4 rooms

ब5 rooms

凹6 rooms

$\square 7$ rooms

प8 rooms

\9 rooms

Q10 rooms and over

Figure 57. Number of rooms in farmhouse (in percent).

Clearly Upland South and Corn Belt farmsteads can be distinguished. Additional finds by Trewartha were: (1) No cotton farms had windmills, while 25 percent of corn and livestock farms did; (2) 41 percent of cotton farms had cattle yards, while 80 percent of corn and livestock farms had cattle yards; (3) only 2 percent of cotton farms had silos, while 21 percent corn and livestock farms had silos; (4) only 9 percent of cotton farms had a granary, while 22 percent of corn and livestock farms had a granary; and, (5) 15 percent of cotton farms had a corn crib, while 52 percent of corn and livestock farms had a corn crib. Finally, only 7 percent of cotton farms had a machine shed, while 42 percent of corn and livestock farms had a machine shed. Farm house architecture appears to be a sensitive indicator of cotton south versus corn and livestock material culture. The breakdown of rooms, for instance, indicates that 19 percent of cotton farms had three to four rooms, 59 percent had five to seven rooms, and 22 percent had eight to 10 rooms (Figure 57). 
Corn and livestock rooms broke down as follows: three to four rooms10 percent, five to seven rooms- 43 percent and eight to 10 rooms47 percent. Some 87 percent of the farm houses in the cotton region were one story, while only 43 percent of corn and livestock farms were one story. Some 68 percent of corn and livestock farms were two stories. Only 10 percent of cotton farm houses had a basement, but 60 percent of corn and livestock farm houses had a basement. Generally, that Upland South farmsteads appear to be smaller in size, had fewer numbers of buildings, and smaller houses than Corn Belt farmsteads. Other architectural attributes characteristic of the Upland South include:

1. Wide use of horizontal log construction (Kniffen and Glassie 1966: 48)

2. Universal modular (pen and crib) construction (Newton 1974: 152) including single-pen, double-pen, dogtrot, and saddlebag housing (Wilson 1974)

3. I-house as an indicator of economic attainment (Kniffen 1965: 557)

4. Transverse crib barns (Meyer 1975: 61).

There are few architectural remains on the installation, however there are foundations. Historical documents clearly indicate this form of construction for Brown County, but that it was replaced by balloon frame construction and later brick homes in Bartholomew and J ohnson Counties, more in keeping with Northern influences. Archaeological investigation of foundation ruins would add to our knowledge of the architectural transition at Camp Atterbury.

\section{Agricultural continuum: From upland South to corn belt agriculture}

In attempting to look at Upland South and Corn Belt economic patterns, which are overwhelmingly agriculturally based, a hypothetical model of the local Upland South-Corn Belt agricultural economy may be manifested in the archaeological record. This model (Figure 58) should be seen as a continuum in which agricultural practices developed as the local population increased, a community was established, agricultural technology advanced, and as a result the landscape was changed. Within this continuum are found differing types, or perhaps, economic levels of farming, defined by the degree to which they:

1. Depended on hunting versus farming

2. Participated in the community and market economy

3. Devoted land to crops

4. Devoted time and land to a particular crop or animal

5. Owned property and material goods. 


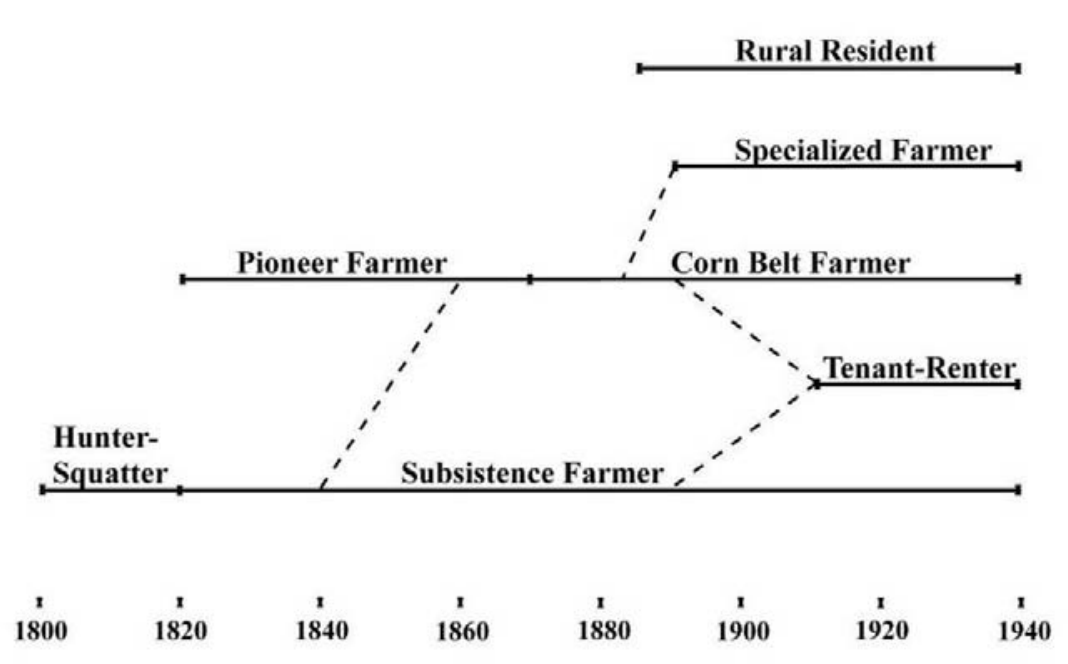

Figure 58. The Agricultural Continuum.

Chronologically, the agriculturists in the Camp Atterbury region area can be loosely typed as:

1. Hunter-squatters

2. Pioneer agriculturists

3. Subsistence farmers

4. Corn Belt farmers

5. Specialized farmers

6. Tenant-renters.

It is important to stress that the types of agricultural practices described are observable types within a continuum. There was a great deal of mobility within this continuum and individuals could move along it with good or bad fortune. In other words, these types do not represent a class system, although they do represent different levels of economic and material wealth that may be observed in the archaeological record via the cultural material present. Exactly when these types were first observable on the landscape is based on the historic research to date. Archaeological and historical research should refine this general chronology.

Based on the historic overview, the development of the agricultural economy in this area began with the hunter-squatter, defined by Price and Price (1978: 7) as "highly mobile and subsistence was based on hunting, trapping, fishing, and trading with little emphasis, if any, on agriculture." Essentially, these were the vanguard of the Upland South migration into the region. They devoted the vast majority of their family economic effort 
to hunting and gathering. They may have not even had a family, but simply came through the area hunting, exploring and staying for a season or two.

As was noted in the history, later settlers found the hunter-squatter's abandoned homesteads and would temporality use them until the later settlers could build their own homes. Hunter-squatter's may have raised some crops such as corn, but more likely did not, and relied mostly on hunting and gathering. They bartered for needs they could not get from the land. It is hypothesized that the hunter-squatter lifestyle all but disappeared from the landscape (to be replaced by the subsistence farmer) shortly after county formation around 1825. Hunter-squatters often did not purchase the land on which they settled.

Those hunter-squatters who did not move out of the area often became Upland South subsistence farmers. Subsistence farmers, as defined here, were less mobile than hunter-squatters, devoting more time to raising crops. They were the first permanent settlers. However, they had minimal participation in the developing market economy by focusing on a cash crop or livestock. They did not purchase the land they settled immediately. Subsistence farmers were extremely flexible in their farm economy. They hunted, trapped, fished, bartered, and grew corn for feeding both the family and the animals. In Brown County during the late 19th century, timber sales were one method for subsistence farmers to obtain cash for those items they could not make or grow. Subsistence farming, to some degree, continued until the arrival of the U.S. Army, but was reduced significantly through the late $19^{\text {th }}$ century in the J ohnson County region and much of Bartholomew County. Subsistence farming persisted in Brown County and even increased during the Depression. The number of subsistence farmers in the Camp Atterbury region after the turn of the $20^{\text {th }}$ century is unknown at this time.

Pioneer agriculturalists arrived on the Camp Atterbury landscape concurrently with the subsistence farmer. Every early settler arrived as a subsistence farmer, but the pioneer farmer arrived with the full intention of farming as a full-time occupation, raising a cash crop, and most importantly, creating and participating in a market economy and developing a community. They were looking for fertile land. It is likely that the majority of pioneer agriculturalists settled in the flat lands of Camp Atterbury - the Hog Bottoms and J ohnson County (Figure 59). 


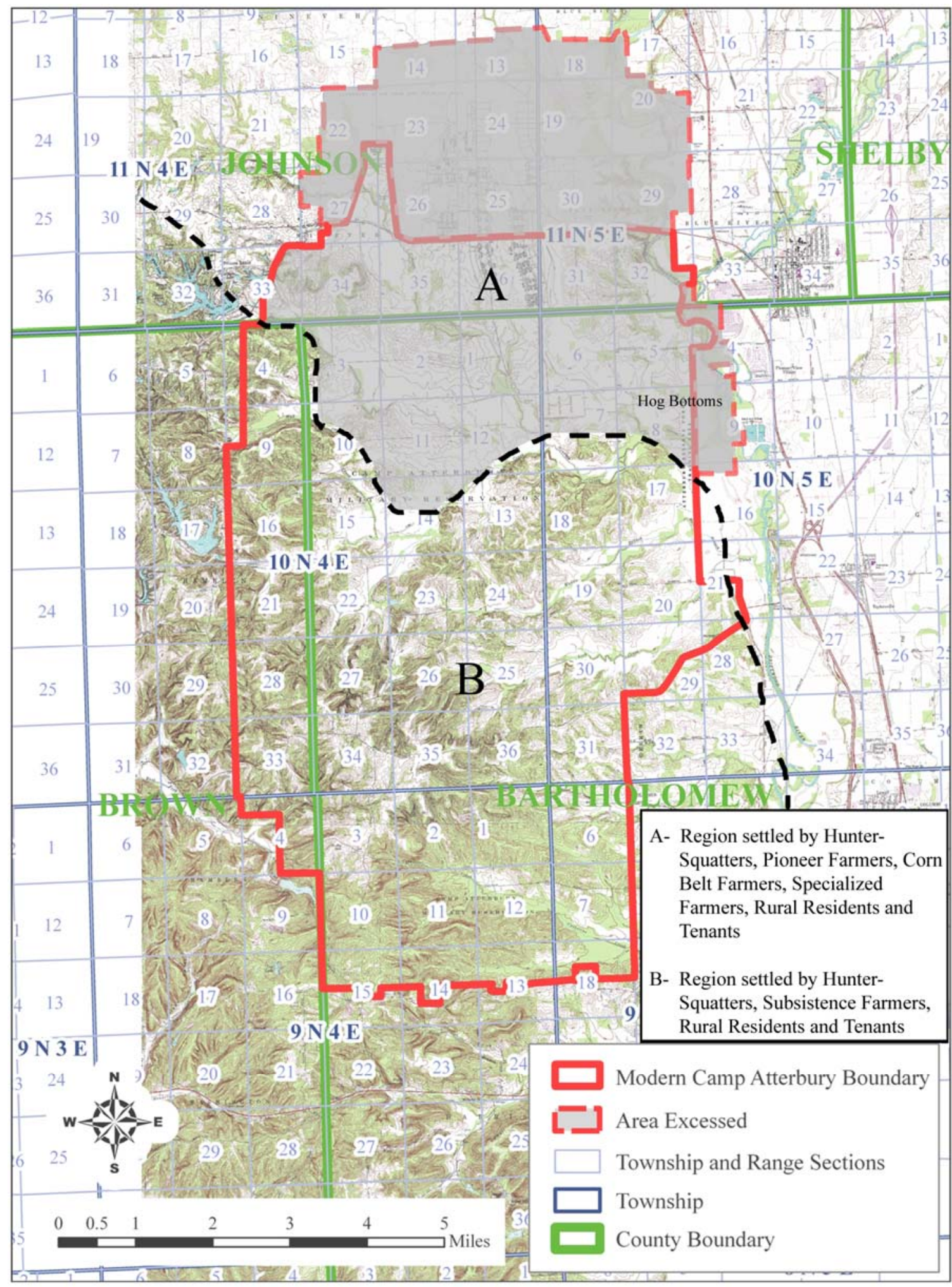

Figure 59. Generalized regions for Camp Atterbury Agriculturalists. 
Pioneer agriculturists brought with them equipment and money and purchased land for farming either immediately or soon after arrival in the region. The author believes that many of these people came from the northern states rather than the Upland South, but that is a hypothesis that needs to be tested through additional historical research. Pioneer agriculturists were entrepreneurs who used additional means of increasing their wealth, as opposed to simply subsisting. They built mills, provided the impetus for the formation of local government, established churches, and ran for local office. It is expected that archaeological sites dating to the Pioneer period are difficult to distinguish from the subsistence farmer's sites in the 1820 s. As the $19^{\text {th }}$ century continued, it is expected that the archaeological signature between pioneer and subsistence farming sites became more distinct (see below). For instance, as pioneer agriculturalists became more economically stable, they built I-houses to replace their log structures and used the log structures as storage sheds.

The Corn Belt Culture developed throughout the Pioneer period. People from the Upland South, Mid-Atlantic, and New England regions blended to become Midwesterners or Hoosiers. After the Civil War, Corn Belt culture dominated the landscape and Corn Belt farms, now archaeological sites, became the dominant part of the built landscape. Successful Pioneer farmers and their offspring became Corn Belt farmers. Corn Belt Farming is defined as full participation in the local agricultural economy; including raising hogs, growing primarily corn, and diversifying with hay and wheat. Farm sizes were generally from 80 to 250 acres of land, and averaged 100 acres. Along with corn and pigs, minor commodities included cattle, sheep, and potatoes. Some fruit was also grown for market.

Like the Pioneer farmers, they were very flexible, adapting their effort to the market and the environment. Corn was in demand through the late 19th century, so while they were flexible in the choice of crops for their gardens, they did not need to be flexible in their choice of cash crops. Corn Belt farmers owned their land and were full members of the active growing community. They were the driving force behind civic progress. A few prospered and were able to buy steam-driven, and later gasoline-powered, equipment, but most made some profit. The wealthiest farmers built multi-room brick homes, large barns, and silos, but simple craftsmen and bungalow style homes were also common. The "hay day" of these people was the late $19^{\text {th }}$ century. They suffered an economic downturn beginning in the mid 1920s, but survived through the Depression. 
The Corn Belt farmer was an opportunist. Starting around 1880 some began to specialize in dairy farming, stock farming, or established commercial orchards. Specialized farming is distinguished from general farming only in the degree to which farm labor and space was devoted to a single cash crop or commodity that was not corn. Even specialized farmers were generalists to a degree; however, the majority of their effort went towards developing a single marketable commodity like dairy or beef. Specialized farmers owned land and fully participated in community development and the marketplace like other Corn Belt farmers.

Tenant farming began sometime in the late $19^{\text {th }}$ or early $20^{\text {th }}$ century and continued up to the arrival of the U.S. Army. Little is known about tenancy in the Camp Atterbury region in the $20^{\text {th }}$ century, but it is not considered as severe a form of poverty as it was in the South at this time. Some tenants were actually renters, paying a monthly or yearly rent and operating independently from the farm owner. Some farms were rented by other Corn Belt farmers who owned their own farm and rented someone else's fields to increase profits. Of course there were some share-tenants, but the tenant arrangement details are unknown.

There was also a type of Camp Atterbury resident that the author has labeled "rural resident." Rural residents lived in the country, but were not farmers, although they probably had small gardens. Some were laborers or worked in town. Others were teachers, preachers, elected officials, blacksmiths, businessmen and professionals (lawyers, etc.), living in the rural areas of Camp Atterbury. Some people lived on farms, but only farmed part-time.

The author believes that each of the identified types of farms and farmers described above may have a distinguishing archaeological signature, which will be found at Camp Atterbury. For instance, the archaeological signature of a Pioneer farmer should be quite different than the huntersquatter. These signatures, once identified and refined, may prove to be similar to those found in other regions of the country or unique to Corn Belt Culture (Smith 1993; Smith 1999; Smith et al. 1982). These signatures will be discussed in detail below.

\section{Archaeological manifestations of the upland South to corn belt culture}

The historic cultural resources at Camp Atterbury, primarily archaeological sites, represent the material culture remains of an Upland South cultural tradition that was transformed into Midwesterner Corn Belt Culture 
as a result of the blending of Upland South, Mid-Atlantic, and (to a lesser extent) New England cultures. Though little archaeological excavation or testing of the historic resources has been conducted at Camp Atterbury, most historic sites have been inventoried through surveys. Drawing on past survey work and the historic settlement history provided in Chapters 2 through 4 (pp 11-92), this section discusses and hypothesizes about the archaeological manifestations that are expected to be present on the installation. This discussion presents a series of hypotheses and observations that will assist in determining how historic resources at Camp Atterbury can be evaluated for their National Register eligibility and appropriately managed. Following this examination, historic themes and future research objectives are presented.

The archaeological manifestations of this historic context are primarily farms, homesteads, small service centers (churches, schools, villages), and associated activity areas like trash dumps. Table 24 lists the expected types of pre-installation historic archaeological sites expected at Camp Atterbury, along with their date range, hypothesized visibility on the landscape, recognizability as a particular site type, and sensitivity to human impact (terms explained further in chapter). The following discussion explains the table in greater detail and its meaning and use for cultural resource managers at Camp Atterbury. It is expected that this table will be refined, modified, or even rejected based on future work.

Archaeological sites at Camp Atterbury fall into a relatively few functional classes and types (Table 24). Four classes of sites have been identified in the historic settlement history:

1. Farms

2. Community Service Centers

3. Special Activity Sites

4. Transportation-related Sites.

Each of the site types within each class is expected to have several distinct archaeological components. However, as these components make up an entire site, they are subsumed under their appropriate type for the purposes of discussion and context. It is recommended that future research and management continue this arrangement whenever possible. For instance, under the class Farms, the various components of a farmstead archaeological site (barns, dwelling, and outbuildings) are all subsumed under each site type like Hunter-Squatter, Corn Belt, or Tenant-Renter. 
Table 24. Classes and types of archaeological sites in Camp Atterbury, IN.

\begin{tabular}{|c|c|c|c|c|}
\hline Site Class/Type & Date Range & Visibility & Type Sign. & Sensitivity \\
\hline \multicolumn{5}{|l|}{ Farms } \\
\hline Hunter-squatter & $1800-1825$ & Very Low & Very Low & High \\
\hline Subsistence & $1820-1940$ & Low-Medium & Very Low & High-Medium \\
\hline Pioneer & $1820-1870$ & Medium & Medium & Medium \\
\hline Corn belt & $1870-1940$ & High & Medium & Low \\
\hline Specialized & $1920-1940$ & High & Medium-High & Low \\
\hline Tenant-renter & $1880-1940$ & High & Low & Medium \\
\hline Rural resident & $1920-1940$ & Medium & Low & Medium \\
\hline \multicolumn{5}{|c|}{ Community Service Centers } \\
\hline Mills (saw and grist) & $1820-1940$ & High & High & Low \\
\hline General store/P.O. & $1830-1940$ & Low-Medium & Low-Medium & Medium \\
\hline Schools & $1840-1940$ & Medium-High & Medium-High & Medium \\
\hline Churches & $1830-1940$ & Medium-High & Medium-High & Medium \\
\hline Cemeteries & $1830-1940$ & Medium-High & High & High \\
\hline Hamlets, villages & $1830-1940$ & High & High & Medium \\
\hline \multicolumn{5}{|c|}{ Special Activity Industries } \\
\hline Stills & $1830-1940$ & Low & High & High \\
\hline Tanneries & $1830-1930$ & $?$ & $?$ & High \\
\hline Portable sawmills? & $1910-1940$ & Low & Medium & High \\
\hline Lumber Villages & $1880-1890$ & $?$ & $?$ & Medium \\
\hline Blacksmiths & $1820-1940$ & Medium & Medium & Low \\
\hline Trash dumps & $1820-1940$ & High & Medium & Low \\
\hline \multicolumn{5}{|l|}{ Transportation } \\
\hline Bridges & $1870-1940$ & High & High & Low \\
\hline Ferries, fords & $1820-1940$ & Medium & High & Low \\
\hline Roads & $1820-1940$ & Medium & High & Medium \\
\hline
\end{tabular}

\section{Site classes and types}

Note that trash dumps are listed separately. This is in recognition of the practical problem of associating many of the trash dumps found in fields or hollows with one particular farm. Artifacts in such dumps may be far removed from their primary use area or the location of initial discard. Still, when dumps can be recognized as part of a particular farmstead, they should be incorporated into the research and management plans for that farmstead. It is also recognized that this list does not include the full range of possible rural sites. Rather, the list pertains to the most common historic sites found strictly within the Camp Atterbury area. 
The different types of farms listed in Table 24 have been previously discussed under the agricultural continuum. The next class of sites-Community Service Centers - are those low order central places where local farmers and other members of the community would have had raw materials processed, products marketed, exchanged, traded or purchased, and where the community would have gathered for social-political-religious activities. The type sites include early saw and grist mills, general stores, gas stations, post offices (often combined with general stores), schools and public assembly areas (often combined), churches (and associated cemeteries), and a clustered settlement constituting a hamlet or village like Kansas. Whenever these sites can be combined under the site type "village or hamlets," they should be for research and management purposes. Otherwise, they stand alone (like a gas station) as a separate site type. Mills are included here rather than at the Special Activity and Industrial Site Class because early mills in the pioneer period were also community centers and some later mills, like the Furnas Mill, served the community as a recreation area long after it ceased operation as a mill.

Special Activity class of sites are sites created as a result of a unique activity or process that was not especially community-oriented or had a commercial industrial purpose, and were not part of a farm. At Camp Atterbury, many known specialized industrial activities like the blacksmith shops, tanneries, and gas stations were usually located at villages and occasionally on farms. Again, where that occurs, they should be treated as part of the village, in the Community Service Center or Farms Site Class. However, if industrial, manufacturing and cottage industry sites do exist outside of a village, and can be located, they should be added to the list in this class. For instance, it is assumed that portable saw mills were used during the later stages of the timber industries' invasion of Brown County. However, it is not known if they occurred within Camp Atterbury. Likewise, it is not known if the lumber industry was intense enough to construct temporary lumber camps within Brown County, and if they did, if they occurred within the Camp Atterbury border. If not, this site type can be eliminated with additional research.

Finally, Transportation-related sites are those physical manifestations on the landscape that assisted human transportation, like roads and ferries. To understand the Camp Atterbury landscape fully, an attempt to reconstruct the original road system might be a useful research goal. Also, it would be interesting to know if the road from Columbus to Martinsville still has a remnant signature on the landscape. 


\section{Approximate date range}

Table 24 ( $p$ 142) lists an estimate of the dates in which the various site types occurred at Camp Atterbury. Further research should refine these dates.

\section{Visibility}

Column three of Table 24 provides a hypothesized measurement of an archaeologist's ability to locate these sites on the ground during a typical cultural resource survey. The measurement is subjective and ranges from a Very Low to a High likelihood of finding such sites. This measurement is based on a number of site type attributes including:

1. Expected number and types of artifacts and features found at these sites

2. Degree of permanence of artifacts and features associated with these sites

3. Expected number of sites

4. Existence of other areas of research (like archival) which would assist in locating such sites

5. Intensity and length of site occupation (Adams and Smith 1985: 326).

It is important to point out that this column only measures the degree to which a site might be found and recognized as a site. It does not measure the archaeologist's ability to identify that particular site type, which is measured in the next column. This column and the next two are provided to stress the ephemeral, fragile nature of much of the material culture at Camp Atterbury. It is important to recognize that some sites may be archaeologically invisible and it is recommended that archaeological evaluation be integrated with historical background research for the site and also oral history where feasible.

Some examples of this invisibility are warranted to further clarify the table. Subsistence farmers came into the area with very little material culture, lived off the land, made few small scale improvements, and many moved on. Because the people had little in the way of permanent material culture, the likelihood of finding such a site on a typical archaeological survey is expected to be very low. On the other hand, a subsistence farmer in the $20^{\text {th }}$ century, while generally comparable in socio-economic status with a Pioneer Period subsistence farmer, will have a very large material culture assemblage, not due to their wealth, but simply due to the permanent nature of their $20^{\text {th }}$ century material culture like canning jars, ceramics, nails, and plastics (vide Adams 1980). 


\section{Type signature}

Column 4 of Table 24 (Type "Signature")provides a measure of the relative possibility of identifying a discovered site as a particular site type. The site attributes discussed above in Column 3 (Type "Visibility") are used in conjunction with Column 4 (Type "Signature") to make this decision. Essentially, this column measures the archaeologist's ability, using any and all lines of possible evidence, to identity a particular site as an identified site type. For example, hunter-squatter sites are likely to be not only hard to find, but once discovered as a site, it will be also difficult to distinguish the site as a hunter-squatter site from a subsistence agriculture site of the same period. This also will be true of $20^{\text {th }}$ century farm sites. The low cost of the artifacts usually found at such sites (nails, glass, ceramics) made them easily available to the Corn Belt farmer, tenant-renter, and rural resident. It is hypothesized that the material culture assemblages will look very similar and perhaps may not be distinguishable at all (Santeford et al. 1985: 193; Stine 1989: 366-367). Still, the occupants of these sites had different lifestyles and the frequency of their sites on the landscape will differ as well. Therefore it will be important to attempt to distinguish these different cultural sites to determine how many of each should be preserved. Perhaps deed and other archival research may be able to assist in the effort to distinguish these sites.

\section{Sensitivity}

The Sensitivity column measures the degree to which each site type can withstand modern cultural disturbance (in this case military training) and, if some are disturbed, the degree of loss to the culture history of the area. Essentially, this column is a broad measure of the value of a particular site in relation to the number of expected sites of that type. For example, as a site type, there are expected to be very few hunter-squatter sites (there were few of them in the past), and because there is expected to be few cultural remains, they are probably highly sensitive to any training activities. If a hunter-squatter site is found and identified, it would be considered an important resource, because so little is known about this time period, the people, and what their sites might look like archaeologically.

On the other hand, it is expected that the most common sites found during typical archaeological surveys will be $20^{\text {th }}$ century farmsteads, and of those, Corn Belt will be the most common. These sites will be easily found. Since there is expected to be a larger number of these present, some training on and around these sites probably can be conducted once they have 
been properly identified/ classified. The impacts caused by past military training on some of these sites may be mitigated through additional work at the best preserved examples. Also, viewed as individual sites, they may be not as important as others, unless a particular example has an especially well-preserved and undisturbed farmstead area. Therefore, $20^{\text {th }}$ century site types are listed as Medium to Low Sensitivity, meaning that any one in particular could sustain some impact, if others are withdrawn from impact, preserved, and protected. In this context, Sensitivity will be useful in making determinations of eligibility for archaeological sites although "High, Medium and Low" sensitivity does not equate directly to "eligible or not eligible."

To further clarify the use of Table 24, a final example is provided. Looking specifically at stills, these are special activity sites dating from the very beginnings of occupation and operating individually for short periods of time up to the arrival of the Army. Early stills are expected to be invisible, but later $20^{\text {th }}$ century stills may be found with some frequency (Visibility) (the author has found them in surveys in Kentucky). If found, they are usually easily identifiable as stills (Type Signature). They are highly sensitive (Sensitivity), because there is little to them in terms of material culture.

\section{Research questions for eligibility determinations}

The following research questions are provided as starting points for future National Register evaluations and research. It will allow Cultural Resource Managers at Camp Atterbury to make determinations of eligibility for the National Register for historic sites. That is, if the site in question has sufficient physical integrity as determined by archaeological evaluation, and can likely answer one or more of the following research questions that are tied to the historic context, then the site may be considered eligible for the National Register. It is important to emphasize that these are starting points, and that the questions may be, or should be revised as additional work on such farms are completed.

\section{Theme: Becoming hoosiers, at the margin of corn belt culture}

This is the overall context for Camp Atterbury historic resources, which is the study of how Upland South peoples merged culturally with MidAtlantic and New England peoples to become Hoosiers. In keeping with this context, a number of questions arise that can be tested archaeologically, but other resources can and should be used including historic documents, and oral history. 
General research questions

1. Are Upland South sites and patterns seen in the hills section of Camp Atterbury?

2. To what degree do Camp Atterbury historic resources represent the Upland South Culture?

3. To what degree do Camp Atterbury historic resources represent Midwestern Hoosier culture?

4. Are Midwestern Hoosier sites distributed mostly in the flats section of the camp?

5. What patterns constitute Midwestern culture?

6. How do Camp Atterbury historic farmstead attributes compare to northern Indiana farmsteads?

7. Can the transition from Upland South to Midwestern Hoosier Corn Belt culture be distinguished in the archaeological record?

Socio-economic questions

1. What were the traditional gender roles on the Upland South/Corn Belt farms, and are they identifiable in the archaeology?

2. What was the structure of kin relationships there? Did it define the community? Was it patterned in terms of settlement? Did it change through time?

3. Are the types of agricultural sites described in this chapter archaeologically distinguishable?

4. Are socio-economic differences between Upland South and Corn Belt farms distinguishable in the archaeological record?

\section{Settlement system questions}

1. How well do the settlement patterns described as Upland South fit the Camp Atterbury area?

2. Where do they differ, and become Midwestern?

3. Can the chronology of settlement be seen in the settlement patterns?

4. How were central place sites dispersed across the landscape?

5. Was there a distinctive intrasite settlement pattern for regional farmsteads not like Upland South and therefore Midwestern?

6. Were there distinctive intrasite settlement patterns for each of the agricultural sites described in the continuum discussed above?

7. Is there an archaeological signature for the various types of architecture at Camp Atterbury (I-house, dogtrots, craftsman, bungalow, Queen Ann, Empire)? 
8. What type of folk construction techniques were used in the Camp Atterbury region? Can they be documented using historic photographs if not archaeology?

Archaeological visibility and signature questions

1. Can we identify the range of possible sites known to exist at Camp Atterbury?

2. What do each of these type sites look like archaeologically?

Material culture questions

1. What does the Camp Atterbury Midwestern or Corn Belt culture artifact assemblage look like?

2. What are the similarities and differences in the material culture assemblage between the various agricultural types?

\section{Theme: Pioneer history}

This theme is provided simply to recognize the necessity of continuing research into the early history of the area. The next step is to dig deeper into the settlement history using the land records available to determine the earliest farmsteads and settlements. With this information, archaeological surveys should attempt to locate these specific sites.

\section{Pioneer questions}

1. Can we identify the earliest settled areas and sites?

2. Was the hills section settled later than the flats areas like Hog Bottom?

3. Were the first farmsteads all located in the valleys?

4. Where are the earliest roads? Do remnants exist?

5. Can early industries be found (tanneries)?

\section{Theme: Corn belt history}

This theme is provided to recognize the necessity of continuing research into the character of Corn Belt culture, generally 1870 to 1940 . This context has only scratched the surface in defining its cultural characteristics. This research can be approached through history and archaeology. 
Corn Belt history questions

1. What are the distinguishing characteristics of Corn Belt or Midwestern Culture?

2. How did the transition from Upland South to Corn Belt culture occur?

Theme: Midwestern industry, business and agricultural specialization

Historic research to date has failed to find much information about industries in the Camp Atterbury area. There is not much known about Collier's Mill, Furnas Mill, the tanneries, the lumber or timber industry, and the portable sawmills in the area. Likewise, there is not a lot of information about general stores, blacksmiths, gas stations, post offices, and other professionals in the area. Furthermore, there was obviously at least one commercial orchard. All of these were hinted at, but very little information was found. There are just enough hints in this record to know that such industries and other non farming businesses, while not a large part of the community, did exist.

\section{Midwest industry, business questions}

1. What are the industries in the Camp Atterbury area?

2. What is the history of the Colliers and Furnas Mills?

3. Who were the post officers and where were the post offices in the area? Was one in Whittington?

4. Where are the tanneries and small saw mills in the area?

5. Were there any temporary lumber camps in the area?

\section{Theme: The depression landscape}

There is still a great deal of information about the Depression in this area that can be gained. The historic overview in this report only scratched the surface. One area that was not pursued in detail, for practical reasons, was the newspaper accounts related to the region (newspaper searching is time consuming), but would yield a deeper level of analysis for the region. It is possible that when the Army arrived, it made a careful survey of the properties and people of the area and these records may still exist (and may include photos of houses). Finally, aerial photography exists for the farms in the area. These photographs could be used in a variety of ways, including assisting in geographic information system (GIS) mapping. All of this could provide a microscopic level of detail and create a unique opportunity to reconstruct the landscape of Camp Atterbury during the first part of the $20^{\text {th }}$ century. 
Another time consuming, but rewarding area of research is oral history. Using the platform of the annual reunions, Camp Atterbury cultural resource managers could institute a program of recording information from long time residents and their descendants. Herman J ohnson, who was moved from his family's land, but worked for Camp Atterbury is an example of the amount of information that would be helpful toward understanding and managing cultural resources at Camp Atterbury.

\section{Depression questions}

1. How did the Depression affect the residents of Camp Atterbury?

2. Did the Depression affect people in the hills section differently than in the flats or prairie sections of Camp Atterbury?

3. What were the effects of Depression era programs on the residents of Camp Atterbury (i.e., Civilian Conservation Corps [CCC] camps, Work Projects Administration [WPA] WPA and Public Works Administration [PWA] construction projects)?

\section{Theme: U.S. Army acquisition}

Much more could be learned about the Army acquisition of the area. This process was painful, but is a lasting memory of the modern central Indiana community and can be used as a springboard for answering many of the questions posed above in any of the themes. That is, Indiana residents are interested in the topic and hold an annual reunion. This reunion can be used as a means of learning about the lives of people in the area during the entire Camp Atterbury history from 1820 to 1940.

\section{Management of historic resources}

This final section of this historic context provides suggestions for the management of historic resources dating from 1800 to 1940 in light of the historic settlement history described in previous chapters and the historic context identified in this chapter. It is understood that the process of inventory, evaluation, and management of these resources will be conducted within the framework of the various cultural resource regulations beginning with the National Historic Preservation Act, as amended, the Archaeological Resources Protection Act, Army Regulation 200-1, and the Indiana Army National Guard Integrated Cultural Resources Management Plan. Nothing herein is intended to supersede the goals or intentions of these regulatory documents. 


\section{Inventory}

Inventory of historic resources at Camp Atterbury should continue while previously identified resources should be integrated into the historic context herein and an attempt should be made to organize those resources within the historic site types described. While the basic Section 110 and Section 106 surveys should continue, historic research should attempt to locate areas that potentially could be the locations of various specific farm and other site types described above. Once these areas are identified, a focused field effort should be conducted to locate these sites. For instance, deed and plat research could focus on finding the earliest settler site followed by an archaeological survey of that parcel to locate that homestead. Assuming such a site could be found, the site would obviously be of interest and should be evaluated using the National Park Service criteria for evaluation of National Register eligibility.

GIS-related research could integrate old maps into the system to locate the original roads and possibly identify the remnants of the old road from Columbus to Martinsville. Through a combination of plat maps and historic aerials, GIS may be a useful tool for finding the earliest sites and identify the flow of settlement in the area.

\section{Evaluation}

As sites are identified, a workable test excavation strategy should be designed for evaluating the Camp Atterbury farmsteads based on work at other Upland South and Midwestern sites. Based on previous research (Carlson 1990; J urney and Moir 1987; Smith et al. 1982), the archaeological expression of a farmstead is often a broad thin sheet midden with small clusters of artifacts where features such as house and barn foundations, storm cellars, smokehouse fire box, wells and cisterns have intruded more deeply into the ground. Dumping of trash is often off-site, although occasionally a ring of trash separating the outer circle from the inner circle of the farmstead builds through time.

At Camp Atterbury, it can be expected that dumping occurred down narrow hollows and in intermittent streams near the farmstead. Another aspect of rural life is considerable recycling of materials for multiple uses; therefore, causing trash accumulations to be small. This means that the sites are, in comparison to deeply buried sites, very sensitive to disturbances. As noted, it will be very difficult to find the early farmsteads and, once found, they will be difficult to assess because the archaeological ex- 
pression is spread thinly across the landscape. Shovel testing may locate such sites, but may not be the best way to assess the sites. More intensive efforts may be necessary to discover the extent of the site, the degree of disturbance, and the number of artifacts present. Testing of these sites may require intense, systematic shovel tests, $1 \mathrm{x} 1$ meter units or other means to determine site integrity. The point is that farmstead features can often be overlooked and sites determined ineligible simply because there appears to be few artifacts; when in fact, there are numerous artifacts and features present that shovel testing alone can not find. Methodologies and research designs should be specific to each site.

There is also the issue of farm location continuity that could pose a significant problem to future research. Additional research and survey may determine that most Pioneer farms became Corn Belt farms at the same location. A pioneer farmer arrives in 1823, settles down, the farm remains in the family through the generations and the farmstead remains in the same location from 1823 to 1940. Pioneer farm archaeological components are overlaid by Corn Belt components making distinguishing them very difficult, except through isolated features with sealed artifacts. The fact that artifacts are durable (early $19^{\text {th }}$ century ceramics were still in use in the 1880s) may increase this difficulty. On the other hand, intensive archaeological excavation at such a site may reveal insights into the transition from Pioneer to Corn Belt to Depression farming on a single site.

The criteria set forth in 36 CFR 60.4 state that a site is significant if it:

1. Is associated with events that have made a significant contribution to the broad patterns of our history

2. Is associated with the lives of persons significant to our past

3. Embodies the distinctive characteristics of a type, period, or method of construction, or represent the work of a master, or possess high artistic values or represent a significant and distinguishable entity whose components may lack individual distinction

4. has yielded or is likely to yield information important to prehistory or history.

Usually archaeological sites are deemed significant if they have archaeological integrity and may yield important information. The historic context and themes described above should help identify the important questions that Camp Atterbury resources can answer and, therefore, form the basis for determining National Register eligibility. Another level of research effort will identify important personages at the local level that should allow 
another option for determining site eligibility. The evaluation of historic resources should use an ethnoarchaeological approach to gather data from all possible data sources to evaluate sites.

\section{Management}

Inventory and evaluation are all part of the management process. As evaluation of the Camp Atterbury sites continues, and sites are evaluated using the context and themes above (modified as necessary), it is recommended that at least one good example of each site type be determined eligible for the National Register and managed appropriately. Ideally, areas representing past landscapes could be nominated as rural landscapes. Within these landscapes, several site types could be preserved, thereby opening other areas for military training. Obviously, this context should be integrated with the Integrated Cultural Resource Plan to ensure that there are no contradicting goals.

As noted throughout this chapter, efforts should be made to incorporate the inventory, evaluation, and management process with the local community and the obvious point of entry is the annual reunion. Cultural resource managers should conduct oral interviews when possible and present archaeological and historical findings at the Camp Atterbury Museum, Bartholomew County Historical Society, J ohnson County Historical Society, and Brown County Historical Society. It is understood that such steps have been taken and this should be continued and expanded as opportunities present themselves.

\section{Conclusion}

Camp Atterbury has a unique and interesting settlement history, tied to the process that transformed the American pioneer into a Midwestern Hoosier. It is important to note that this context has necessarily taken a broad brush to the local history, and there is much more to learn about the Camp Atterbury region. The purpose of this context was to provide cultural resource managers at Camp Atterbury with a broad framework within which to evaluate and manage the historic period resources at the camp. It is expected that this context will be refined and modified as archaeological survey, inventory, and evaluation progresses. 


\section{References}

\section{Print sources}

Adams, William H., and Steven D. Smith. 1985. Historical Perspectives on Black Tenant Farmer Material Culture: The Henry C. Long General Store Ledger at Waverly Plantation, Mississippi. In, Theresa Singleton, editor, The Archeology of Slavery and Plantation Life, New York: Academic Press, pp. 309-334.

Adams, William H., Steven D. Smith, David F. Barton, Timothy B. Riordan, and Stephen Poyser. 1981. Bay Springs Mill: Historical Archaeology of a Rural Mississippi Cotton Milling Community. Washington D.C: National Technical Information Service.

Advisory Council on Historic Preservation. 1989. The Section 110: Guidelines: Working with 106. Washington, D.C.: National Park Service.

Anonymous. 1914. Education Report, J ohnson County Schools 1914. Typed manuscript, on file, Vertical File, "Schools," Franklin, Indiana: J ohnson County Museum of History, J ohnson County Historical Society.

. 1876. Complaint of Non-Payment of Toll. Vertical files, Columbus, Indiana: Bartholomew County Historical Society.

1946. Letter to Mrs. Mary E. Arbuckle. From Office of the Division Engineer, Ohio River Division. J uly 22. On file, Vertical File, "Camp Atterbury," Columbus, Indiana: Bartholomew County Historical Society, American Guide Series.

—. 1941. Indiana: A Guide to the Hoosier State. New York: Oxford University Press.

Arensberg, Conrad M. 1955. American Communities. American Anthropologist 57(6):1143- 1162.

Bailey, Dorthy Birney. 1991. History and Families, Brown County, Indiana. Brown County Historical Society, Paducah, Kentucky: Turner Publishing Company.

Baker, J . David. n.d. The Postal History of Indiana, Volumes 1 and II. Louisville, Kentucky: Philatelic Bibliopole.

Baker, Ronald L. 1995. From Needmore to Prosperity: Hoosier Place Names in Folklore and History. Bloomington: Indiana University Press.

Banta, D. D. 1888. History of J ohnson County, Indiana. Chicago: Brant \& Fuller. Bartholomew County Historical Society (BaCHS)

_ 1976 History of Bartholomew County Indiana - 1888. Columbus, Indiana: Bartholomew County Historical Society. Original.

- 1888. History of Bartholomew County, Indiana-1888. Columbus, Indiana: Bartholomew County Historical Society. 
Bergen, J ohn V., compiler and editor (Atlas of J ohnson County). 1984. Illustrated Historical Atlas of J ohnson County, Indiana 1820 to 1900. J ohnson County Historical Society, Indianapolis: William B. Burford Printing Company. (A compilation of previously published atlas's from 1866 through 1900 and county histories 1881-1913).

Blake, I George. n.d. Pioneers of J ohnson County, Indiana. Manuscript, on file, Franklin, Indiana: J ohnson County Museum of History, J ohnson County Historical Society.

Blee, Kathleen M. 2002. Women of the Klan: Racism and Gender in the 1920s. Berkeley: University of California Press.

Branigin, Elba L. 1913. History of J ohnson County, Indiana. Indianapolis: B.F. Bowen \& Co., Inc., Brown County Genealogical Society.

—. 2006. Newsletter, Winter, Volume 20(4). On File, Nashville: Brown County Historical Society.

Bush, Leslie L. 2004. Boundary Conditions: Macrobotanical Remains and the Oliver Phase of Central Indiana, A.D. 1200-1450. Tuscaloosa: The University of Alabama Press.

Carlson, Shawn Bonath. 1990. The Persistence of Traditional Lifeways in Central Texas. In Historical Archaeology on Southern Plantations and Farms, edited by Charles E. Orser, Historical Archaeology 24(4):50-59.

Carmony, Donald F. 1966. A Brief History of Indiana. Indianapolis: Indiana Historical Bureau.

. 1998. Indiana: 1816-1850, The Pioneer Era. Indianapolis: Indiana Historical Bureau and Indiana Historical Society.

Chang, K. C. 1972. Settlement Patterns in Archaeology. Module 24 in Anthropology, Reading, Massachusetts: Addison-Wesley Publishing Company.

Clark, George P. 1989. Through Indiana by Stagecoach and Canal Boat: The 1843 Travel J ournal of Charles H. Titus. Indiana Magazine of History LXXXV(3):193-235.

Clarke, David L. (editor). 1977. Spatial Archaeology. New York: Academic Press.

Clendenen, H. L. 1973. Settlement Morphology of the Southern Courtois Hills, Missouri, 1820- 1860. Ph.d. dissertation, Baton Rouge: Louisiana State University.

Cline \& McHaffie. 1874. The People's Guide: A Business, Political and Religious Directory of Bartholomew County, Indiana. Indianapolis: Indianapolis Printing and Publishing House.

Columbus Republican. 1895. Schools. Newspaper article on file, Columbus, Indiana: Bartholomew County Historical Society.

—_. 1941. County Heads and Camp Men Discuss Roads. 29 May 1941. Newspaper article on file, Columbus, Indiana: Bartholomew County Historical Society.

Crumley, Carole L., and William H. Marquardt. 1987. Regional Dynamics: Burgundian Landscapes in Historical Perspective. San Diego: Academic Press. 
Crump, Ross. n.d. Early Transportation in Bartholomew County. Typed manuscript on file, Columbus, Indiana: Bartholomew County Historical Society.

David, Bruno, and J ulian Thomas, eds. 2008. Handbook of Landscape Archaeology. Walnut Creek, California: Left Coast Press.

Dawson, Audrey, Steven D. Smith, and Christopher Ohm Clement. 2008. Cultural Resource Survey of the Pittman Analysis Area, Enoree Ranger District, Sumter National Forest, Newberry and Union Counties, South Carolina. Columbia: South Carolina Institute of Archaeology and Anthropology.

Douglas, Benjamin Wallace. 1926. The New Deal Comes to Brown County. New York: Doubleday, Doran and Company, Inc.

Essex, Miriam. 1976. “One Room Schools, Nineveh Twp., Bartholomew Co.” Handwritten manuscript, on file Columbus, Indiana: Bartholomew County Historical Society.

Flannery, Kent V. 1974. Culture History versus Cultural Process: A Debate in American Archaeology. In New World Archaeology: Theoretical and Cultural Transformations, compiled by Ezra B. W. Zubrow, Margaret C. Fritz, and J ohn M. Fritz, San Francisco: Freeman and Company,. pp. 5- 8. Originally published in Scientific American, August 1967.

Flatrock Association. 1899. Minutes of Flatrock Association 1823-1899. On file, Franklin, Indiana: J ohnson County Museum of History, J ohnson County Historical Society.

Fischer, David Hackett. 1989. Albion's Seed: Four British Folkways in America. Oxford University Press, New York.

Fisher, Richard Swainson, ed. 1852. Indiana: In Relation to its Geography, Statistics, Institutions, County Topography,Etc., With a "Reference Index" To Colton's Maps of Indiana. New York: J.H. Colton.

Ford, Denzil L. n.d. Early History of Hamblen Township in Brown County Indiana. Bound manuscript on file, Brown County Historical Society, Nashville, Indiana.

Ford, Lacy K. 1986. Yeoman Farmers in the South Carolina Upcountry: Changing Production Patterns in the Late Antebellum Era. Agricultural History 60(4):1737.

Franklin Democrat. 1912. Teachers and Officials of the Schools of J ohnson County, Indiana 1912-1913 (November 12). On file, Franklin, Indiana: J ohnson County Museum of History, J ohnson County Historical Society.

1913. Furnas' Mill Burns. Newspaper article, August 8. On file, Franklin, Indiana: J ohnson County Museum of History, J ohnson County Indiana Historical Society.

Franzmeier, Donald P. 1997. Cradle of Life: Soils. In Marion T. J ackson, editor, The Natural Heritage of Indiana, Bloomington, Indiana: Indiana University Press, pp. 45-58.

Futato, Eugene M. 1989. An Archaeological Overview of the Tombigbee River Basin, Alabama and Mississippi. Report of Investigations 59, Division of Archaeology, Tuscaloosa: Alabama State Museum of Natural History, University of Alabama. 
Glassie, Henry. 1968. Pattern in the Material Folk Culture of the Eastern United States. Philadelphia: University of Pennsylvania Press.

1975. Folk Housing in Middle Virginia: A Structural Analysis of Historic Artifacts. Knoxville: University of Tennessee Press.

Goetz, A. H. n. d. "History" Typed one page manuscript on file vertical files, Columbus, Indiana: Bartholomew County Historical Society.

Hamblen, Porter. 1940. A History of the Hamblen and Allied Families. Franklin, Indiana: Franklin Democrat.

Hart, J ohn F. 1977. Land Rotation in Appalachia. Geographical Review 67:148- 166.

Hedge, Roger L. 1997. Forest Swell and Swale: The Central Till Plain Natural Region. In Marion T. J ackson, editor, The Natural Heritage of Indiana, Bloomington, Indiana: Indiana University Press, pp. 195-200.

Hibbs, Ruby Graves. 1987. "Early Education in Nineveh Township, J ohnson County, Indiana." Typed manuscript, on file, Vertical Files, Franklin: J ohnson County Museum of History, J ohnson County Historical Society.

. 2007. Earlier Times in Nineveh Township. Franklin, Indiana: Franklin Printing Service.

Homoya, Michael A., D. Brian Abrell, J ames A. Aldrich and Thomas W. Post. 1985. The Natural Regions of Indiana. In Proceedings of the Indiana Academy of Science, 1984, Volume 94:245-268.

Homoya, Michael A., and Hank Huffman. 1997. Sinks, Slopes, and a Stony Disposition: The Highland Rim Natural Region. In Marion T. J ackson, editor, The Natural Heritage of Indiana, Bloomington, Indiana: Indiana University Press, pp. 167171.

Hodder, Ian, and Clive Orton. 1976. Spatial Analysis in Archaeology. London: Cambridge University Press.

Hoover, Dwight W. and J ane Rodman. 1980. A Pictorial History of Indiana. Bloomington, Indiana: Indiana University Press.

Howe, Robert C. 1997. Of Time, Rocks, and Ancient Life: Bedrock Geology. In Marion T. J ackson, editor, The Natural Heritage of Indiana, Bloomington, Indiana: Indiana University Press, pp. 3-14.

IARNG. 2008. Indiana Integrated Cultural Resources Management Plan. On file, Environmental Office, Camp Atterbury.

Indiana Geological Survey Map 26. 1997. From, Marion T. J ackson, ed., The Natural Heritage of Indiana, Bloomington, Indiana: Indiana University Press, p. 20.

Jackson, Marion T. 1997. The Natural Heritage of Indiana. Bloomington, Indiana: Indiana University Press, pp. 3-14.

J ohnson County Historical Society. n.d. Vertical Files, “Mills” Franklin, Indiana: J ohnson County Museum of History, J ohnson County Historical Society.

J ohnson, Paul. 1991. The Birth of the Modern World Society, 1815-1830. New York: Harper Collins Publishers. 
J ordan, Terry G., and Mattie Kaups. 1989. The American Backwoods Frontier: An Ethnic and Ecological Interpretation. Baltimore: J ohn Hopkins University Press.

J urney, David H., and Randall W. Moir (eds.). 1987. Historic Buildings, Material Culture, and People of the Prairie Margin: Architecture, Artifacts, and Synthesis of Historic Archaeology. Richland Creek Technical Series, vol. 5. Archaeology Research Program, Institute for the Study of Earth and Man, Southern Methodist University, Dallas.

Kellar, J ames H. 1983. An Introduction to the Prehistory of Indiana. Indianapolis: Indiana Historical Society.

Kniffen, Fred B. 1960. To Know the Land and Its People. Landscape 9(3):20-23.

1965. Folk Housing: Key to Diffusion. Annals of the Association of American Geographers 55(4):549- 575.

Kniffen, Fred B., and Henry Glassie. 1966. Building in Wood in the Eastern United States, A Time-Place Perspective. Geographical Review 56:40- 66.

Lewis, Kirsten, and Karstin Carmany-George. 2008. Section 106 Cultural Resource Investigation: Improvement of Trails within Training Areas 301-312, Indiana National Guard, Camp Atterbury, Edinburgh, Indiana. Report on file, Camp Atterbury Environmental Office, Indiana.

Lewis, Peirce F. 1990. The Northeast and the Making of the American Geographical Habits. In Michael P. Conzen, editor, The Making of the American Landscape, Winchester, Massachusetts: Unwin Hyman, Inc., pp. 80-103.

McClelland, Linda Flint, J . Timothy Keller, Genevieve P. Kellar, and Robert Z. Melnick. 1991. Guidelines for Evaluating and Documenting Rural Historic Landscapes. National Register Bulletin No. 30, Washington, D.C.: National Park Service.

McCray, Mary Ann. n.d. Schools. Vertical Files, Columbus, Indiana: Bartholomew County Historical Society.

McCullough, Robert G. 2000. The Oliver Phase of Central Indiana: A Study of Settlement Variability as a Response to Social Risk. Ph.d. Dissertation, Carbondale: Southern Illinois University.

Madison, J ames H. 1982. Indiana Through Tradition and Change: A History of the Hoosier State and Its People, 1920-1945. Indianapolis: Indiana Historical Society.

. 1986. The Indiana Way: A State History. Bloomington, Indiana: Indiana University Press.

Marshall, Robert J ., and J ean Prather. 2003. History of Bartholomew County, Indiana, $20^{\text {th }}$ Century. Columbus, Indiana: Bartholomew County Historical Society.

Meyer, Douglas K. 1975. Diffusion of Upland South Folk Housing to the Shawnee Hills of Southern Illinois. Pioneer America 7(2):56- 66.

Miller, Hugh T. 1940. Chapman Denslow and His Family. Indiana Magazine of History XXXVI:351-368. 
Nassaney, Michael S. 2009. European Exploration and Early Settlements. In, Francis P. McManamon, General Editor, Archaeology in America: An Encyclopedia, Volume 2, Midwest and Great Plains/ Rocky Mountains. Westport, Connecticut: Greenwood Press, pp.45-52.

National Park Service. 1991. How to Complete the National Register Multiple Property Documentation Form. National Register Bulletin 16B, Washington, D.C.: National Park Service.

Newman, J ames E. 1997. Our Changing Climate. In Marion T. J ackson, editor, The Natural Heritage of Indiana, Bloomington, Indiana: Indiana University Press, pp. 85-98.

Newton, Milton B., Jr. 1971. The Annual Round in the Upland South: The Synchronization of Man and Nature through Culture. Pioneer America 3(2):6373.

1974. Cultural Preadaptation and the Upland South. In Man and Cultural Heritage: Papers in Honor of Fred B. Kniffen, edited by H. J. Walker and W. G. Haag, p. 143- 154. Geoscience and Man, vol. 5. School of Geoscience, Baton Rouge: Louisiana State University.

Nicholson, Howard Lee. 1992. Swine, Timber, and Tourism: The Evolution of an Appalachian Community in the Middle West, 1830-1930. Ph.D. Dissertation, Department of History, Oxford, Ohio: Miami University.

Noble, Vergil E. 2009. Contact Period Culture Change, Population Decline, and Movement. In, Francis P. McManamon, General Editor, Archaeology in America: An Encyclopedia, Volume 2, Midwest and Great Plains/Rocky Mountains. Westport, Connecticut: Greenwood Press, pp.52-56.

Nydegger, J .A. 1914. Rural Schools: Sanitary Survey of Schools in Bartholomew County, Indiana. Public Health Reports (1896-1970) 29(6):342-355.

Otto, J ohn Solomon. 1985. The Migration of the Southern Plain Folk: An Interdisciplinary Synthesis. The J ournal of Southern History 51(2):183- 199.

Otto, J ohn Solomon, and Nain Estelle Anderson. 1982. The Diffusion of Upland South Folk. Southeastern Geographer 22(2):89- 98.

Otto, Sarah. 1987. A History of Edinburgh, Indiana 1820-1986. Franklin, Indiana: Franklin Printing Services.

Parker, George R. 1997. The Wave of Settlement. In Marion T. J ackson, editor, The Natural Heritage of Indiana, Bloomington, Indiana: Indiana University Press, pp. 369-382.

Pence, George. n.d. County Historians Hear Early History of State Road No. 1 As Narrated by George Pence. Columbus Republic, on file, Vertical file "Roads," Columbus, Indiana: Bartholomew County Historical Society.

Philips, Clifton J . 1968. Indiana in Transition: The Emergence of an Industrial Commonwealth, 1880-1920. Indianapolis: Indiana Historical Bureau and Indiana Historical Society.

Polk’s City Directory. 1882-83 Polk’s City Directory. 
Power, Richard Lyle. 1953. Planting Corn Culture: The Impress of the Upland Southerner and Yankee in the Old Northwest. Indianapolis: Indiana Historical Society.

Price, Cynthia R., and J ames E. Price. 1978. "Investigations of Settlement and Subsistence Systems in the Ozark Border Region of Southeast Missouri During the First Half of the Nineteenth Century: The Widow Harris Cabin Project." Paper presented at the Annual Meeting of the Society for Historical Archaeology.

Reid, Robert L., editor. 1987. Back Home Again: Indiana in the Farm Security Administration Photographs, 1935-1943. Bloomington, Indiana: Indiana University Press.

Resnik, Benjamin. 1988. The Williams Place: A Scotch-Irish Farmstead in the South Carolina Piedmont. Volumes in Historical Archaeology III, edited by Stanley South. Columbia: South Carolina Institute of Archaeology and Anthropology.

Sabo, George III. 1990. Historic Europeans and Americans. In George Sabo III, Ann M. Early, J erome C. Rose, Barabara A. Burnett, Louis Vogele, Jr., and James P. Harcourt, Human Adaptation in the Ozark and Ouachita Mountains, by, Arkansas Archaeological Survey Research Series No. 31, Fayetteville: Arkansas Archaeological Survey.

Stewart-Abernathy, Leslie C. 1986. The Moser Farmstead, Independent but Not Isolated: The Archeology of a Late Nineteenth Century Ozark Farmstead. Arkansas Archeological Survey Research Series No. 26. Fayetteville: Arkansas Archeological Survey.

Salstrom, Paul. 2007. From Pioneering to Preserving: Family Farming In Indiana to 1880. West Lafayette, Indiana: Purdue University Press.

Sauer, Carl Ortwin. 1963. The Morphology of Landscape. In Land and Life, A Selection from the Writings of Carl Ortwin Sauer, edited by J ohn Leighly, pp. 315- 350. Berkeley: University of California Press.

Scott, Mina Morris. 1976. Hog Bottom School. Typed manuscript on file, Vertical File, "Schools," Columbus, Indiana: Bartholomew County Historical Society.

Shott, Michael J . 2009. The Earliest Inhabitants of the Midwest. In, Francis P. McManamon, General Editor, Archaeology in America: An Encyclopedia, Volume 2, Midwest and Great Plains/ Rocky Mountains. Westport, Connecticut: Greenwood Press, pp.32-34.

Smith, Steven D. 1993. Made it in the Timber: A Historic Overview of the Fort Leonard Wood Region, 1800-1940. Normal, Illinois: Midwestern Archaeological Research Center, Bloomington-Normal, Illinois: Illinois State University.

1999. A Good Home For A Poor Man: Fort Polk and Vernon Parish. Southeast Tallahassee, Florida: Archaeological Center of the National Park Service. Funded by Department of Defense, Legacy Resource Management Program.

— 2003. Made in the Timber: A Settlement History of the Fort Leonard Wood Region. Champaign, Illinois: ERDC/ CERL Special report 03-05.

Smith, Steven D., David F. Barton, and Timothy B. Riordan. 1982. Ethnoarcheology of the Bay Springs Farmsteads: A Study of Rural American Settlement. Washington, D.C.: National Technical Information Service. 
Smith, Richard C. 1987. Form-Early Mill, Or Mill Site, Built Prior to 1870, "Collier's Mill." On file Franklin, Indiana: J ohnson County Museum of History, J ohnson County Historical Society.

Stafford, C. Russell. 1997. Prehistoric Peoples of Indiana. In Marion T. J ackson, editor, The Natural Heritage of Indiana, Bloomington, Indiana: Indiana University Press, pp. 361-368.

Stine, Linda France. 1989. Raised Up in Hard Times, Circa 1900- 1940. Ph.d. dissertation, Department of Anthropology, Chapel Hill: University of North Carolina.

Stott, Russell. 1980. History of Ohio Ridge. Typed manuscript, on-file, Bartholomew County Historical Society, Columbus, Indiana. Printed in Tri-county Enterprise, Edinburg, Indiana, 1972.

Taulman, Larry and Don G. Wertz, eds. 1999. The Atterbury File and The Atterbury File: The Next Generation. Franklin, Indiana: Custer Baker Middle School.

Talley, Harley. 1928. Study of the Elementary Public Schools of Bartholomew County, Indiana. Master's Thesis, School of Education, Bloomington: Indiana University.

Thornbrough, Emma Lou. 1965. Indiana in the Civil War Era. Indianapolis: Indiana Historical Bureau and Indiana Historical Society.

Trewartha, Glenn T. 1948. Some Regional Characteristics of American Farmsteads. Annals of the Association of American Geographers 38(3):169-225.

Trubitt, Mary Beth. 2009. The Origin, Organization, and Demise of Midwest Chiefdoms. In, Francis P. McManamon, General Editor, Archaeology in America: An Encyclopedia, Volume 2, Midwest and Great Plains/ Rocky Mountains. Westport, Connecticut: Greenwood Press, pp.43-45.

U.S. Bureau of the Census. Unless otherwise noted, the publisher in the following list is the U.S. Department of Commerce, Bureau of the Census, Government Printing Office (GPO), Washington, D.C..

—. 1821 Fourth Census of Population. Gales and Seaton, Washington.

— 1830 Fifth Census of Population. Duff Green, Washington.

—. 1840 Sixth Census of Agriculture.

—. 1841 Sixth Census of Population, 1840.

—. 1853 Seventh Census of Population, 1850.

_ 1854 Compendium of the Seventh Census, 1850. Beverly Tucker, Senate Printer, Washington.

—. 1864 Eighth Census of Agriculture, 1860.

—. 1864 Eighth Census of Population, 1860.

—. 1865 Eighth Census of Manufactures, 1860.

. 1872 Ninth Census of Agriculture, 1870. 
—_. 1872 Ninth Census of Population, 1870.

__ 1872 Ninth Census of Wealth and Industry, 1870.

— 1883 Tenth Census of Agriculture, 1880.

__ 1883 Tenth Census of Manufactures, 1880.

_ 1883 Tenth Census of Population, 1880.

—. 1897 Eleventh Census of Agriculture, 1890.

—_ 1897 Eleventh Census of Population, 1890.

—_. 1902 Twelfth Census of Agriculture, 1900.

__ 1902 Twelfth Census of Population, 1900.

__. 1913 Thirteenth Census of Agriculture, 1910.

— 1922 Fourteenth Census of Agriculture, 1920.

—_. 1922 Fourteenth Census of Population, 1920.

—_ 1923 Fourteenth Census of Manufactures, 1919.

—. 1933 Fifteenth Census of Agriculture, 1930.

—. 1933 Fifteenth Census of Population, 1930.

—. 1941 Retail Trade: 1939.

—_. 1942 Sixteenth Census of Agriculture, 1940.

—_ 1943 Sixteenth Census of Population, 1940.

—. Weaver, David C., and J ames F. Doster

- 1982. Historical Geography of the Upper Tombigbee Valley. Report Submitted to the National Park Service, Albuquerque, New Mexico, University, Alabama: Center for the Study of Southern History and Culture, University of Alabama.

Willey, Gordon R., and Philip Phillips. 1958. Method and Theory in American Archaeology. Chicago: University of Chicago Press.

Wilson, Eugene M. 1974. Form Changes in Folk Houses. In Man and Cultural Heritage: Papers in Honor of Fred B. Kniffen, edited by H. J. Walker and W. G. Haag, pp. 65- 71. Geoscience and Man, vol. 5. School of Geoscience, Louisiana State University, Baton Rouge.

Young, Livy, and Chelsea Dinn. n.d. "Pioneer Map of J ohnson County, Indiana." Manuscript on file, Franklin, Indiana: J ohnson County Historical Society, J ohnson County Museum of History.

Zelinsky, Wilbur. 1951. Where the South Begins, the Northern Limits of the Appalachain South in Terms of Settlement Landscape. Social Forces 30:172-178. 


\section{On-line sources}

Arbuckle, May E. 1952. Chapter 2: Camp Atterbury. In, A History of Army and Navy Training Centers, Camps, Forts, and other Military Installations Within the State Boundaries During World War II, by Dorothy Riker, Indianapolis: Indiana Historical Bureau (J ames D. West, webmaster), http://www.indiana.org/Camp\%20Atterbury/Hoosier TrainingGround/HoosierTraining.htm

Beers, J.H. 1879. Atlas of Bartholomew County. Chicago: J .H. Beers Company.IU-PUI Digital Collections, http://indiamond6.ulib.iupui.edu/cdm4/document.php?CISOROOT=/HistAtlas\&CISOPTR=2700 \&REC $=4$

Brown, Col. Clifford and Col. Richard King, Col. Leland Fine, and CSM J ames E. Engelking. 1981. The History of Camp Atterbury. On-line (J ames D. West, webmaster) http://www.indianamilitary.org/Camp\%20Atterbury/SoThinkMenu/CampAtterburySTART.htm

Fifer, Orien W. "Quiet Village of Kansas is Resigned to Loss of Homes for New Army Camp Near Columbus." Indianapolis News, 15J uly 1941. Posted on-line by J ames D. West(webmaster), http://www.indianamilitary.org/Camp\%Atterbury/Land\%20owners/Kansas.htm

Interurban Railways in Indiana. http://sbcglobalpwp.att.net/w/i/willvdv/interin.html

IU-PUI Library Digital Collections http://www.ulib.iupui.edu/digitalcollections/home.html

Growing a Nation: The Story of American Agriculture, http://www.agclassroom.org/gan/timeline/1840.htm

Hurd, Charles H. 1941. Preliminary Investigation and Survey, Southern Indiana Cantonment, Triangular Division, Columbus, Indiana. On-line (J ames D. West, webmaster),

http://www.indianamilitary.org/Camp\%20Atterbury/SoThinkMenu/CampAtterburySTART.htm

Library of Congress, American Memory Collection, Indiana Maps http://atlas.ulib.iupui.edu/librarycongress_sid/indianamaps.html

West, J ames D. History of Camp Atterbury, http://www.indianamilitary.org/Camp\%20Atterbury/SoThinkMenu/CampAtterburySTART.htm 


\section{Acronyms and Abbreviations}

$\begin{array}{ll}\text { Term } & \text { Spellout } \\ \text { AR } & \text { Army Regulation } \\ \text { CAJMTC } & \text { Camp Atterbury Joint Maneuver Training Center } \\ \text { CCC } & \text { Civilian Conservation Corps } \\ \text { CERL } & \text { Construction Engineering Research Laboratory } \\ \text { CESU } & \text { Cooperative Ecosystems Studies Unit } \\ \text { CFR } & \text { Code of the Federal Regulations } \\ \text { ERDC } & \text { Engineer Research and Development Center } \\ \text { ERDC-CERL } & \text { Engineer Research and Development Center, Construction Engineering Re- } \\ & \text { search Laboratory } \\ \text { GIS } & \text { geographic information system } \\ \text { GPO } & \text { Government Printing Office } \\ \text { KKK } & \text { Ku Klux Klan } \\ \text { MIPR } & \text { Military Interdepartmental Purchase Request } \\ \text { NHPA } & \text { National Historic Preservation Act of 1966 } \\ \text { NRHP } & \text { National Register of Historic Places } \\ \text { PWA } & \text { Public Works Administration } \\ \text { SCIAA } & \text { South Carolina Institute of Archaeology and Anthropology } \\ \text { TR } & \text { Technical Report } \\ \text { USA } & \text { United States of America } \\ \text { WPA } & \text { Work Projects Administration } \\ \text { WWI } & \text { World War I (WWI) } \\ \text { WWII } & \text { World War II (WWII) }\end{array}$




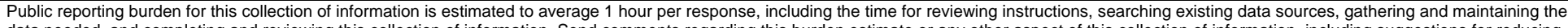

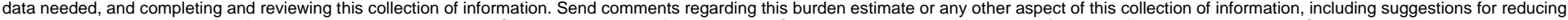

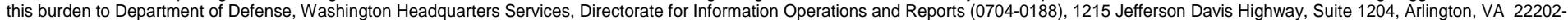

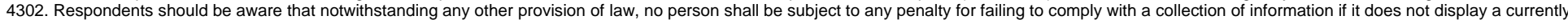
valid OMB control number. PLEASE DO NOT RETURN YOUR FORM TO THE ABOVE ADDRESS.
1. REPORT DATE (DD-MM-YYYY)
2. REPORT TYPE
3. DATES COVERED (From - To)

$17-01-2010$

Final

4. TITLE AND SUBTITLE

The History of American Settlement at Camp Atterbury, Indiana

5a. CONTRACT NUMBER

5b. GRANT NUMBER

5c. PROGRAM ELEMENT

6. AUTHOR(S)

Steven D. Smith and Chris J. Cochran

5d. PROJECT NUMBER

MIPR

5e. TASK NUMBER

5f. WORK UNIT NUMBER

89DATIN060

8. PERFORMING ORGANIZATION REPORT NUMBER

U.S. Army Engineer Research and Development Center (ERDC)

Construction Engineering Research Laboratory (CERL)

PO Box 9005,

ERDC/CERL TR-10-3

Champaign, IL 61826-9005

\section{SPONSORING I MONITORING AGENCY NAME(S) AND ADDRESS(ES)}

Camp Atterbury

J oint Maneuver Training Center, Environmental Office

po bOX 5000

Edinburgh, IN 46124

10. SPONSOR/MONITOR'S ACRONYM(S)

Cultural Resource Manager

11. SPONSOR/MONITOR'S REPORT NUMBER(S)

\section{DISTRIBUTION I AVAILABILITY STATEMENT}

Approved for public release; distribution is unlimited.

13. SUPPLEMENTARY NOTES

\section{ABSTRACT}

This report details the history of 19th and 20th century farm and community settlement within the Camp Atterbury Joint Maneuver Training Center, IN. It also provides a historic context for the identification, evaluation, and preservation of significant historic properties within installation boundaries. This historic context defines property types, poses research questions, and provides evaluation criteria based on the Camp Atterbury Joint Maneuver Training Center's settlement history, in an effort to develop a comprehensive program of multiple site evaluation.

\section{SUBJECT TERMS}

Camp Atterbury, National Registry of Historic Places (NHRP), cultural resources management, historic preservation, historic context

\begin{tabular}{|l|l|l|}
\hline \multicolumn{2}{|l|}{ 16. SECURITY CLASSIFICATION OF: } & 17 \\
\hline $\begin{array}{c}\text { a. REPORT } \\
\text { Unclassified }\end{array}$ & $\begin{array}{c}\text { b. ABSTRACT } \\
\text { Unclassified }\end{array}$ & $\begin{array}{c}\text { c. THIS PAGE } \\
\text { Unclassified }\end{array}$ \\
\hline
\end{tabular}

\begin{tabular}{c|c|c}
$\begin{array}{c}\text { 17. LIMITATION } \\
\text { OF ABSTRACT }\end{array}$ & $\begin{array}{c}\text { 18. NUMBER } \\
\text { OF PAGES }\end{array}$ & \\
\cline { 3 - 3 } SAR & 180 & \\
& &
\end{tabular}

19a. NAME OF RESPONSIBLE PERSON 